RUBENS RAMOS GIANESELLA

\title{
Paisagens no tempo: vilas litorâneas paulistas
}

\author{
Dissertação apresentada na \\ Faculdade de Arquitetura e Urbanismo \\ da Universidade de São Paulo \\ para obtenção do título de \\ Mestre em Arquitetura e Urbanismo \\ Área de Concentração: \\ História e Fundamentos da \\ Arquitetura e do Urbanismo \\ Orientadora: \\ Prof ${ }^{a}$ Dr ${ }^{\text {a }}$ Beatriz Piccolotto Siqueira Bueno
}


AUTORIZO A REPRODUÇÃO E DIVULGAÇÃO TOTAL OU PARCIAL DESTE TRABALHO, POR QUALQÜER MEIO CONVENCIONAL OU ELETRÔNICO, PARA FINS DE ESTUDO E PESQUISA, DESDE QUE CITADA A FONTE.

E-MAIL: rubens.rg@estadao.com.br

Gianesella, Rubens Ramos
G433p Paisagens no tempo: vilas litorâneas paulistas / Rubens Ramos Gianesella. --São Paulo, 2008.

191 p. : il. + anexo em DVD

Dissertação (Mestrado - Área de Concentração: História e Fundamentos da Arquitetura e do Urbanismo) - FAUUSP.

Orientadora: Beatriz Piccolotto Siqueira Bueno

1.Cidades (História) - São Paulo 2.Redes urbanas 3.Índios 4.Paisagem 5.Desenho 6.Imagem (Arte) I.Título

CDU 711.43(091)(816.1) 


\section{AGRADECIMENTOS}

À Prof ${ }^{\mathrm{a}}$ Drª Élide Monzeglio (in memoriam), pelas luzes e cores semeadas nos caminhos deste trabalho.

Sua memória sempre foi um estímulo para completar sua elaboração.

À Prof ${ }^{a}{ }^{-1} r^{\mathrm{a}}$ Beatriz Piccolotto Siqueira Bueno, por ter acolhido a orientação do trabalho com muito carinho e dedicação. Com sensibilidade e sabedoria norteou os rumos seguros da travessia. 


\section{RESUMO}

GIANESELLA, Rubens Ramos. Paisagens no tempo: vilas litorâneas paulistas. 2008. 191 pgs., 1 DVD. Dissertação de Mestrado. Faculdade de Arquitetura e Urbanismo, Universidade de São Paulo, São Paulo, 2008.

A disposição dos povoados, vilas e cidades ao longo do litoral brasileiro sempre foi representação, para a historiografia, da interdependência da Colônia em face da expansão mercantilista européia. Em conseqüência, os estudos sobre a urbanização, fundamentados nos aspectos estruturais e econômicos da Idade Moderna, têm estes espaços como produto cultural dos grupos dominadores. Essa Dissertação de Mestrado procura mudar o foco de análise ao investigar os contextos sociais específicos dos núcleos urbanos nos primeiros eventos do colonialismo. Como suporte para a pesquisa, foram eleitas algumas cidades litorâneas do atual Estado de São Paulo: São Vicente, Santos, Cananéia, Iguape, São Sebastião e Ubatuba. A partir de pesquisas multidisciplinares, entre as Ciências do Urbanismo, História, Arqueologia, Geografia, Sociologia e Antropologia, as investigações evidenciaram a contribuição das sociedades indígenas nos processos de ocupação, não só das Vilas, mas de toda rede urbana. Presentes alguns séculos antes da chegada dos europeus, elegeram essa frente atlântica como habitat, estabelecendo nos nichos ecológicos seus lugares de vivência, estreitamente harmonizados com o meio ambiente. Essas escolhas balizaram a instalação dos futuros espaços urbanos. Os mesmos sítios, antes ocupados por aldeias (grupos locais), serão seqüenciados pela arquitetura de raiz européia. Os novos espaços, portanto, são fruto do encontro cultural entre indígenas e europeus. A percepção do elo afetivo que as pessoas têm com seus lugares, relativo aos povos indígenas, sinalizou que as representações não poderiam traduzir apenas o repertório cultural europeu. Afinal, pequenos grupos de brancos (ou indivíduos!) foram acolhidos por milhares de índios. Interagindo culturalmente conseguiram se adaptar e sobreviver. O novo cenário social decerto moldou a imagem dos aglomerados. A observação dos sítios, cenários ambientais, desenhos e imagens na linha do tempo, revelaram ao longo da pesquisa as evidências de suas singelezas. Uma recorrência nas Vilas estudadas simboliza o enlace dessas vertentes sociais: a articulação do módulo espacial da Matriz com a contigüidade da "rua direita". As aproximações dos núcleos germinais foram obtidas com os levantamentos elaborados pelo Engenheiro Militar João da Costa Ferreira e colaboradores no final do século XVIII. Outra fonte cartográfica foi especialmente utilizada: os levantamentos da Comissão Geográfica e Geológica do Estado de São Paulo, do início do século XX.

Palavras-chave: Vilas litorâneas paulistas. Arqueologia. Indígenas. Sítios. Habitat. Nicho ecológico. Meio ambiente. Paisagem. Social. Lugares de vivência. Núcleos urbanos. Rede urbana. Encontro cultural. Desenhos. Imagem. Rua direita. Caminhos. 


\begin{abstract}
GIANESELLA, Rubens Ramos. Landscapes in time: the São Paulo coast villages. 2008. 191 pgs., 1 DVD. Essay for Master's degree. School of Architecture and Urbanism at the University of São Paulo, São Paulo, 2008.
\end{abstract}

The disposition of the population, villages and cities on the Brazilian coast from the interdependence of the Colony to the European commercial expansion was always seen thru history. Consequently, the studies based on the structural and economical aspects of the modern age, show these spaces as the product of the cultural dominant groups. This Master's degree theory tries to change the focus of these analyses once it investigates the social specific contexts of the urban areas from the first colony events. As support for this research the coastal cities chosen from the current state of São Paulo were: São Vicente, Santos, Cananéia, Iguape, São Sebastião e Ubatuba. From the multidiscipline researches, among the Sciences of Urbanism, History, Arqueology, Geography, Sociology and Anthropology the investigations prove the contribution from the Natives on the occupation process not only in the villages but also in all urban areas. Present a few centuries before the European arrived; they elected the Atlantic front as their "habitat", establishing the places where they would live in straight harmony with the natural environment. These choices had direct influence in the future urban areas. The same places, which were chosen before from the tribes or local groups, would in sequence have the European architectural roots. Therefore the new spaces are the product of the cultural meeting between Europeans and natives. The perceptions of affection that people have with in relation with the places to the natives, demonstrated that it could not only translate the European culture. After all, small groups of whites (or individuals) were accepted by thousands of natives. Interacting culturally they adapted and survived. The new social scenery will definitely mold the image of these groups. The observation of places, environmental scenes and the design and images during the length of time revealed during the research the evidences of its simplicity. A fact in the villages studied symbolizes the enlace of social lines: the articulation of the cathedral with the continuity of "direita street". The closeness of the originating groups was obtained from the data elaborated by the Military Engineer João da Costa Ferreira and the collaborators at the end of the eighteenth century. Another resource was used: the research from the Geographic And Geological Commission from the State of São Paulo, from the beginning of the twentieth century.

Key words: Coastal Villages from São Paulo. Arqueology. Natives. Places. Habitat. Ecological core. Environment. Landscape. Social. Places lived. Urban areas. Cultural meetings. Drawings. Images. "Rua Direita". Paths. 


\section{LISTA DE FIGURAS}

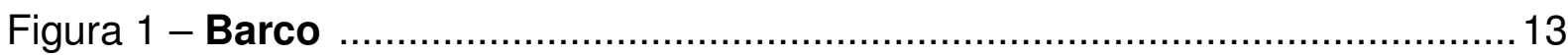

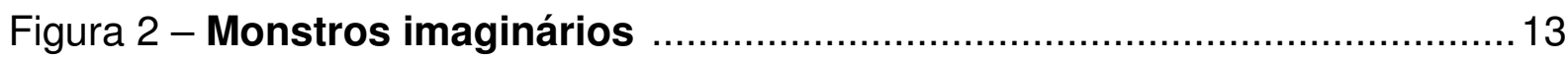

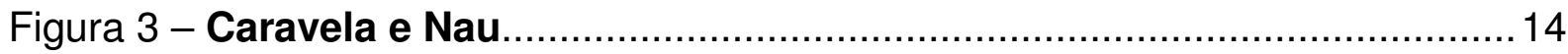

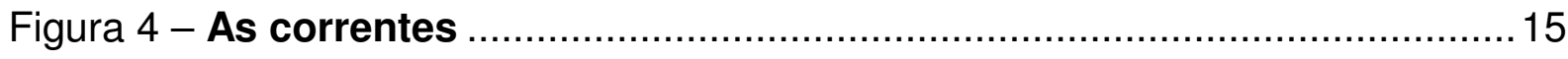

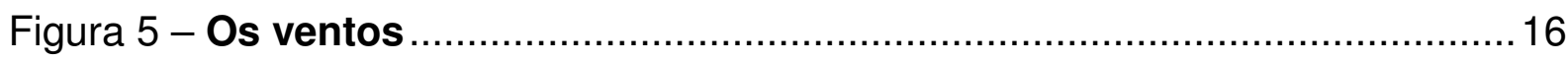

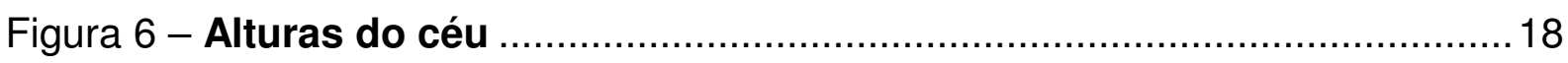

Figura 7 - Esboço da Terra ........................................................................ 19

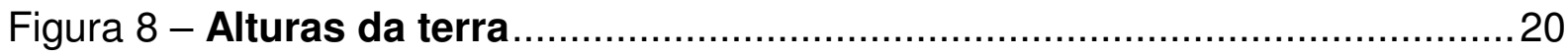

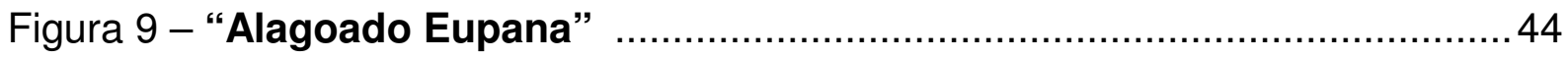

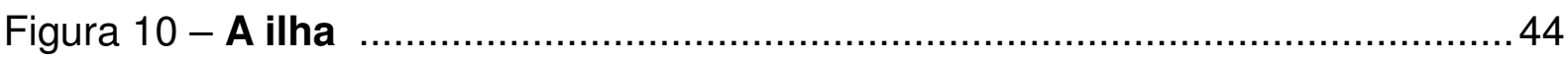

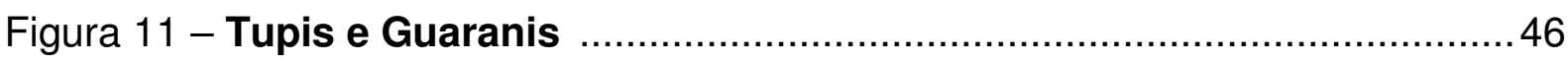

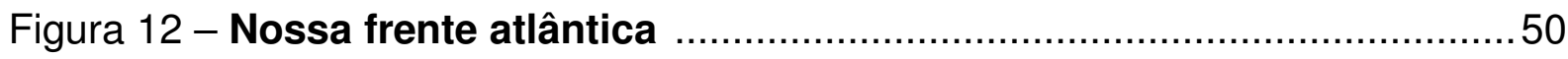

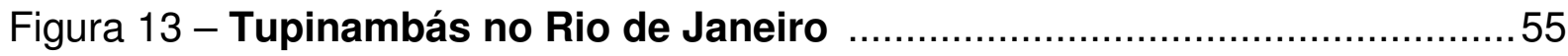

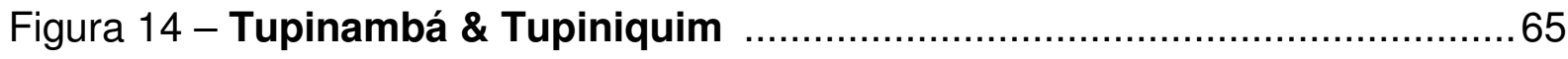

Figura 15 - 0 estratégico acesso do canal de Bertioga ..................................70

Figura 16 - As navegações dos canoeiros …………................................. 71

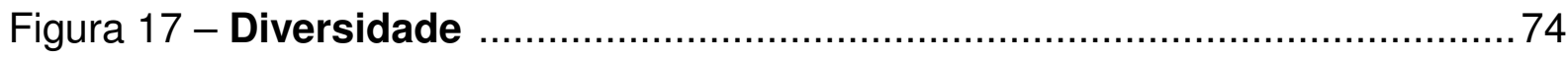

Figura 18 - A trilha dos trilhos da São Paulo Railway ......................................76

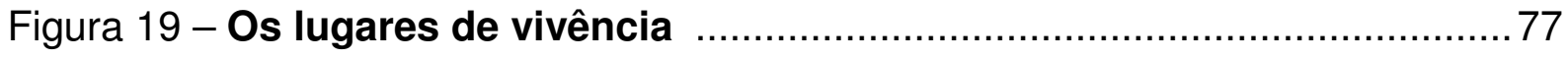

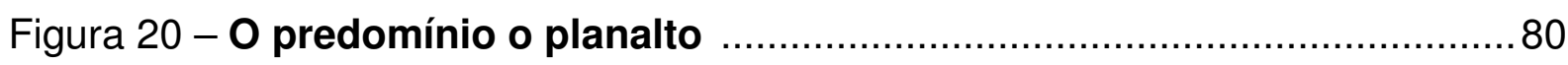

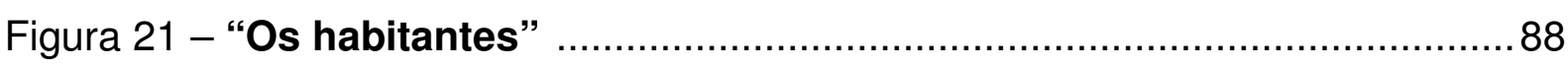

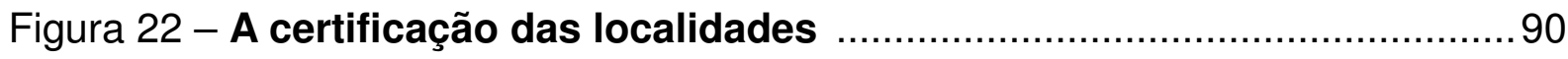

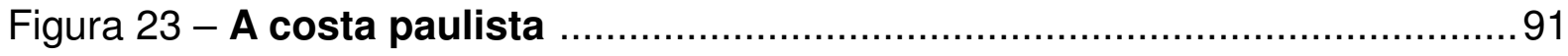

Figura 24 - A persistência do sítio …….......................................................... 100 


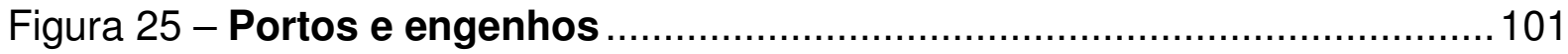

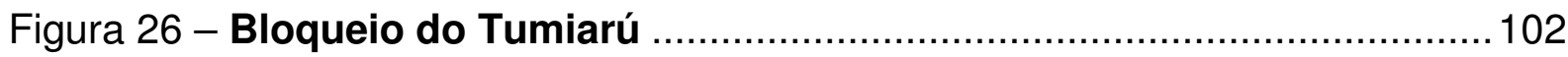

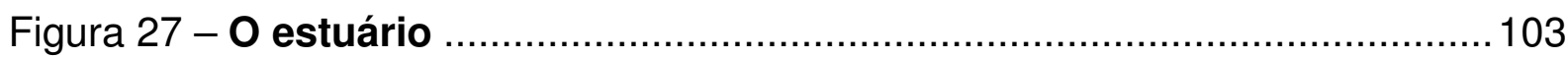

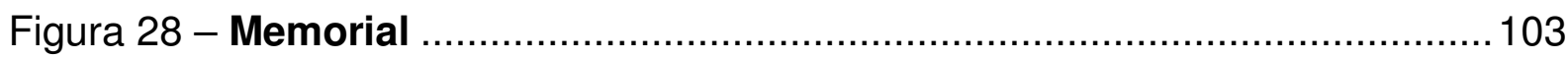

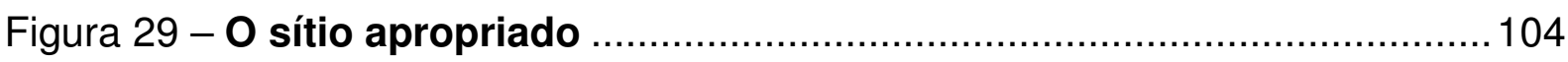

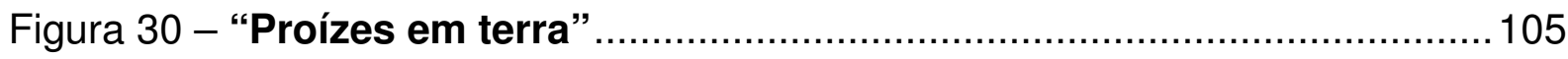

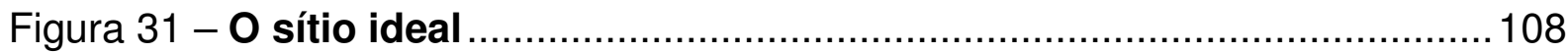

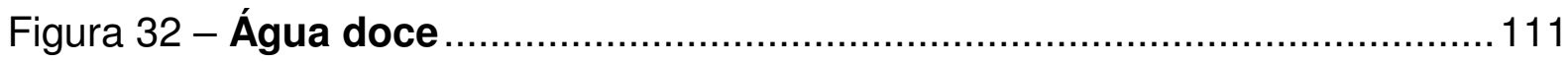

Figura 33 - 0 núcleo no cenário ambiental .....................................................112

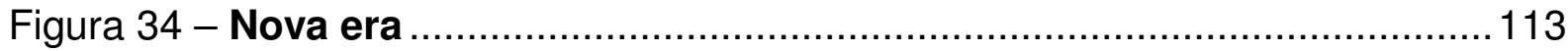

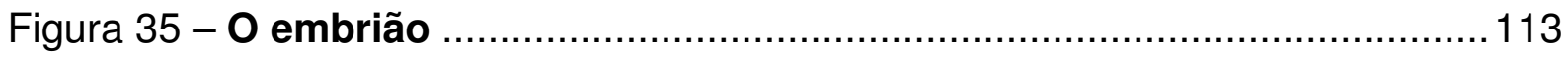

Figura 36 - A imponência do sagrado …………....................................114

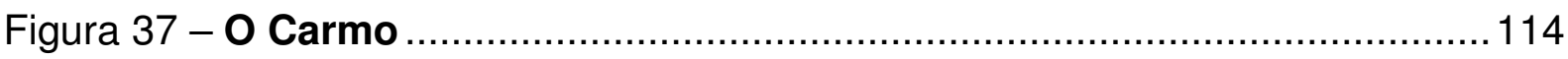

Figura 38 - Igreja e Convento de Santo Antonio...........................................114

Figura 39 - Os edifícios religiosos representam a vila .................................115

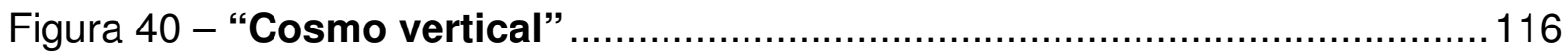

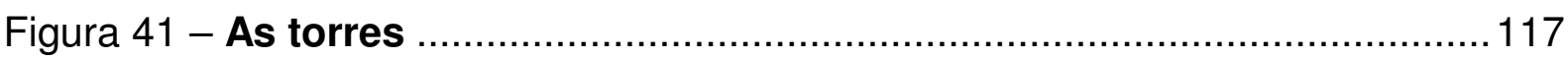

Figura 42 - Os nós articuladores do tecido ................................................118

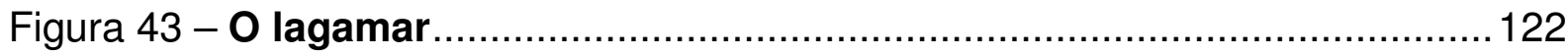

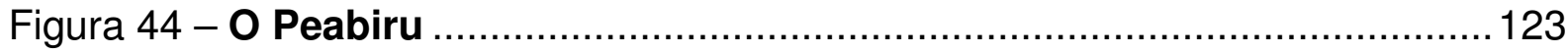

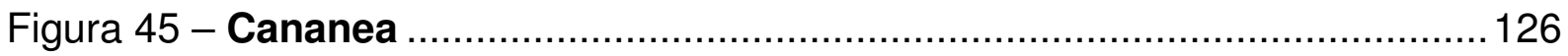

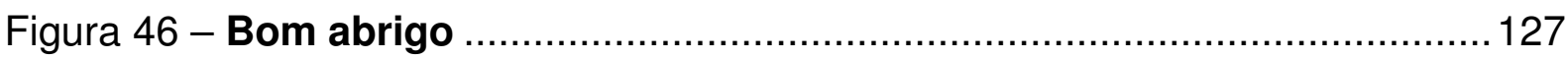

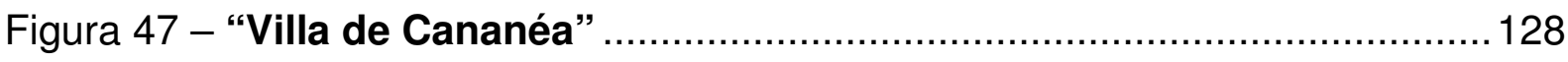

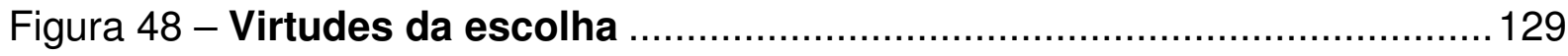

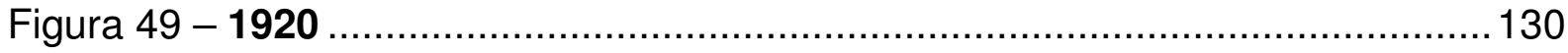

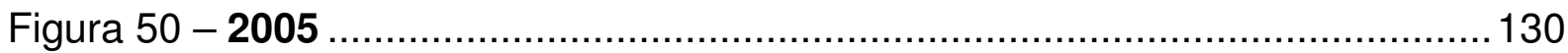


Figura 51 - Vetores

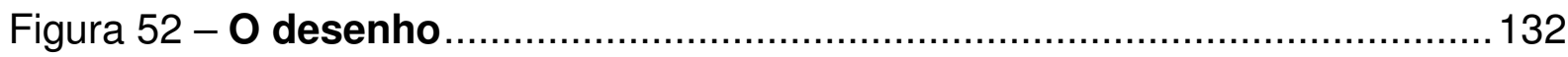

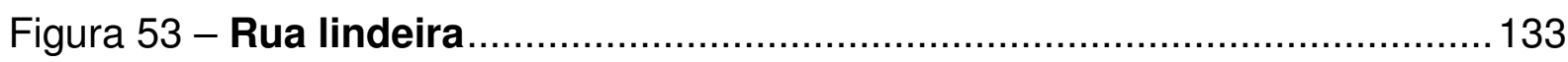

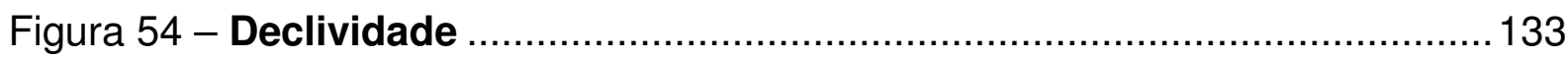

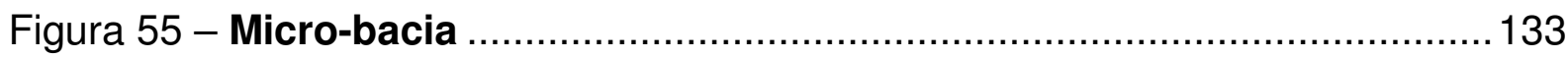

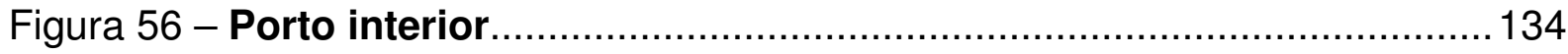

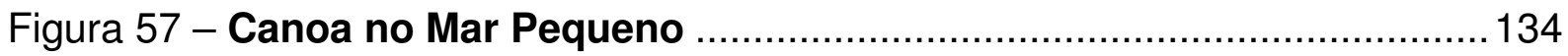

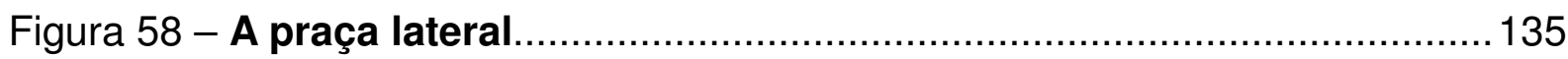

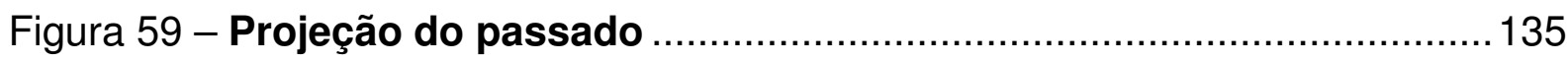

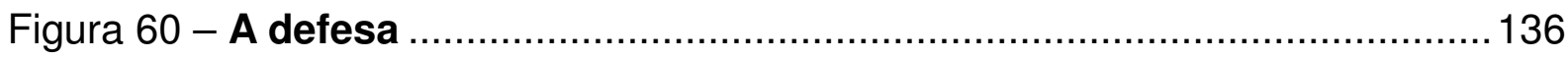

Figura 61 - "Prospeto de Cananea da pte. do porto" ......................................136

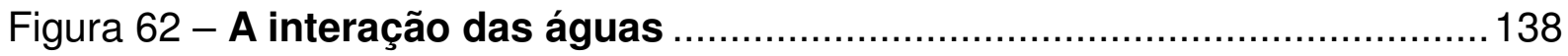

Figura 63 - Novos sítios, velhas escolhas.................................................139

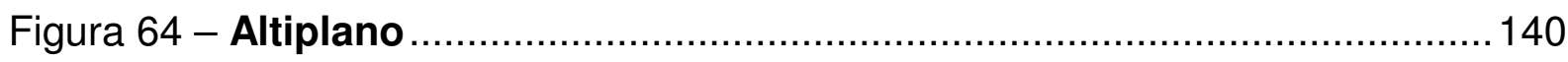

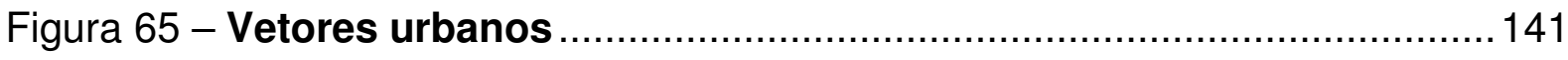

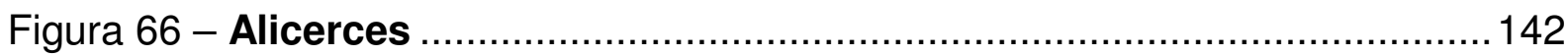

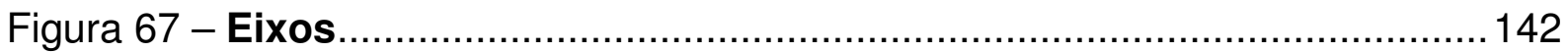

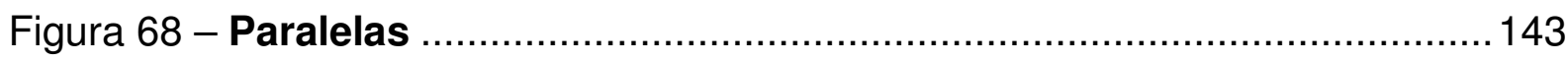

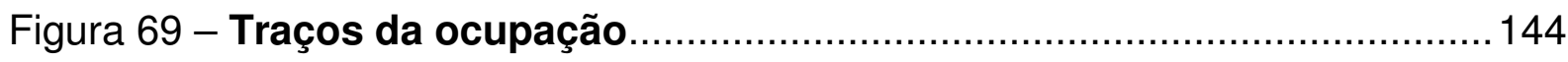

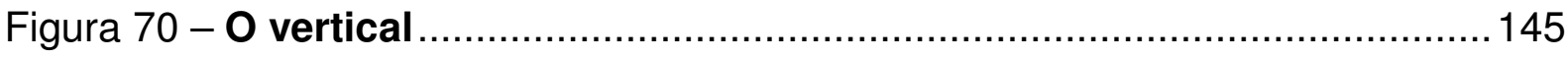

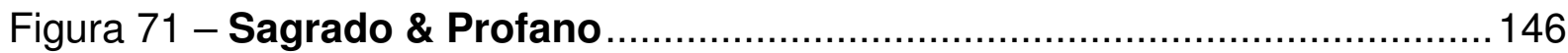

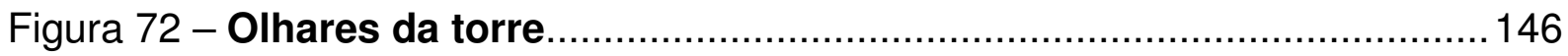

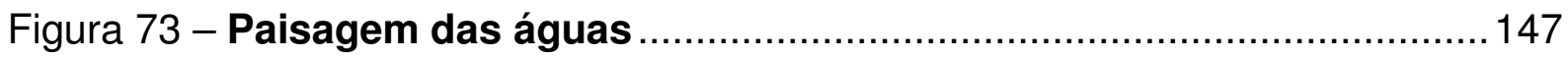

Figura 74 - A caminho do mar ................................................................. 147

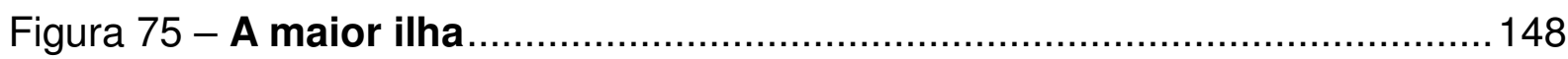




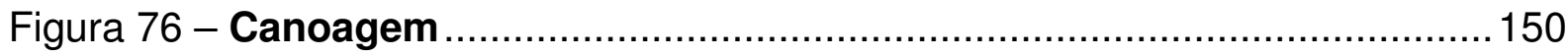

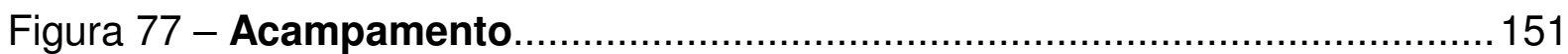

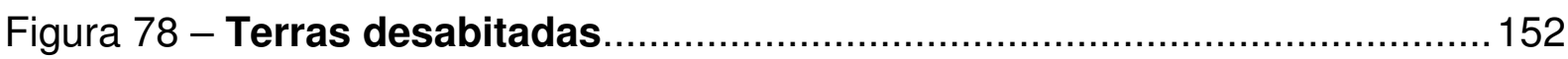

Figura 79 - O valor da "Caridade".............................................................. 154

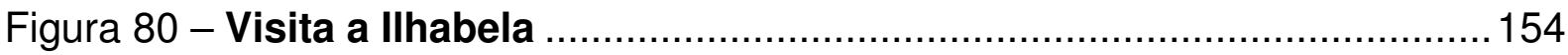

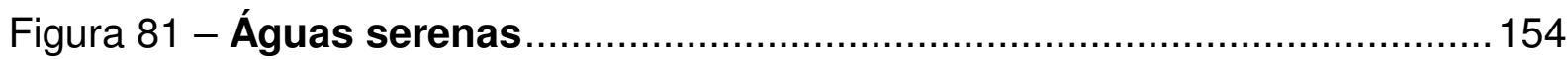

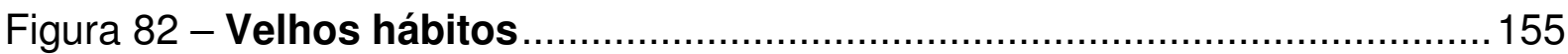

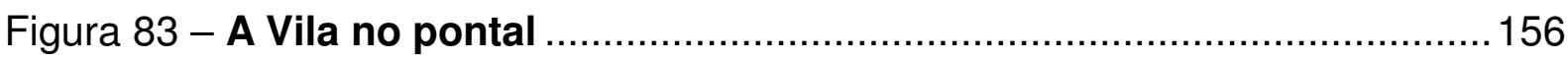

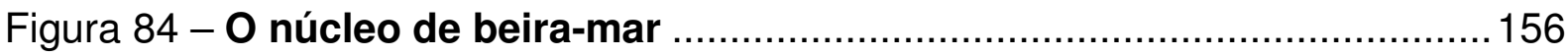

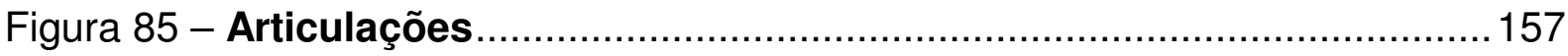

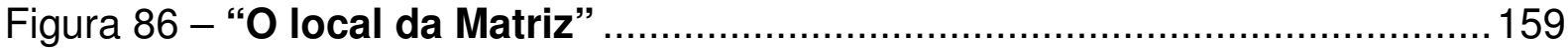

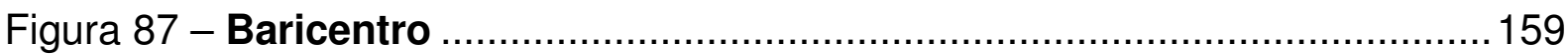

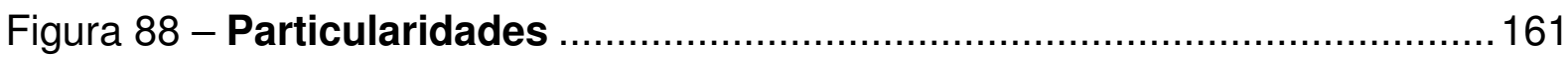

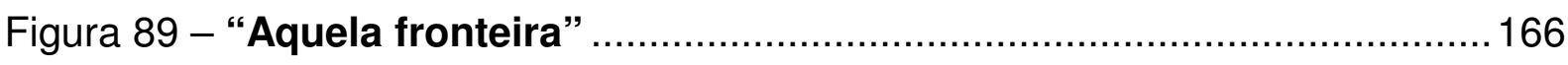

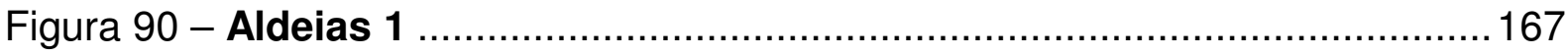

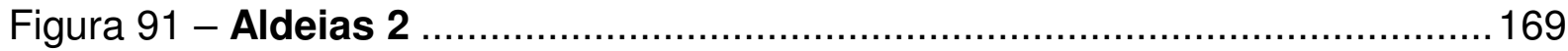

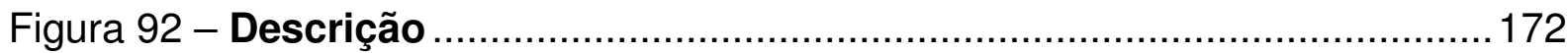

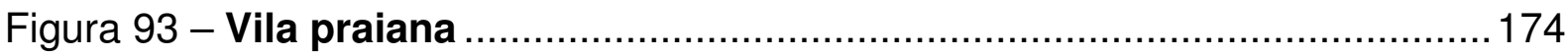

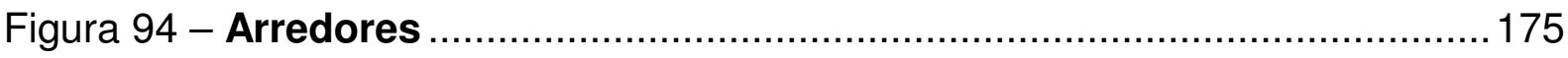

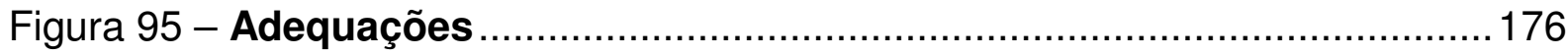

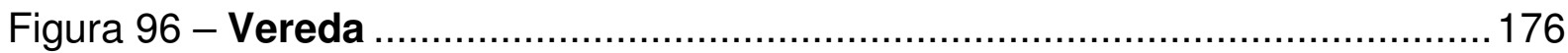

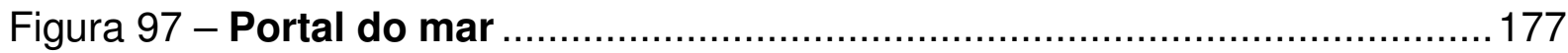

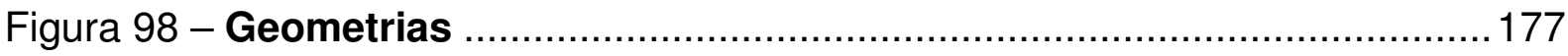

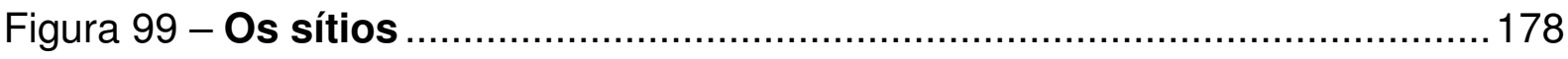

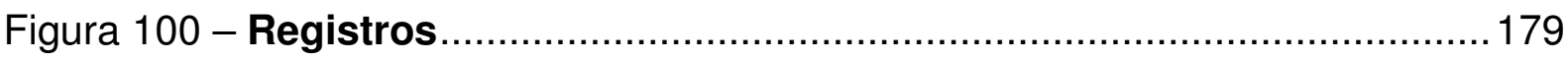




\section{SUMÁRIO}

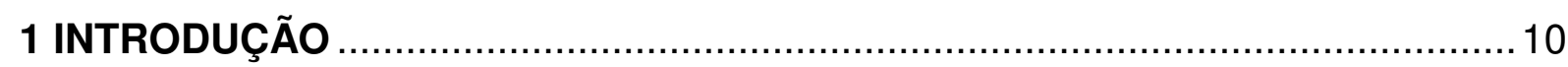

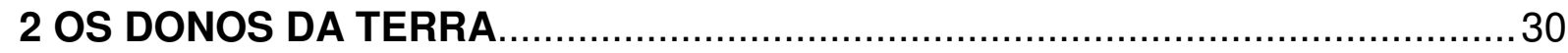

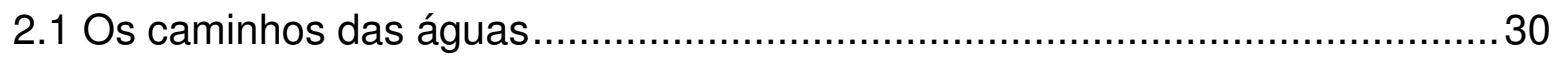

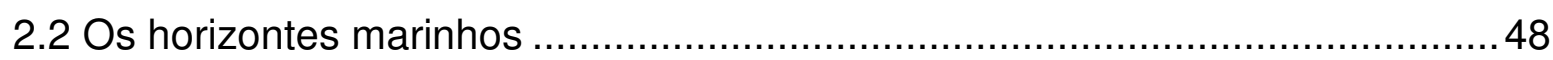

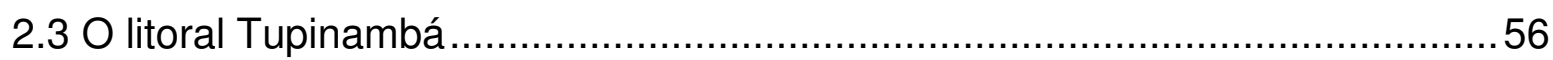

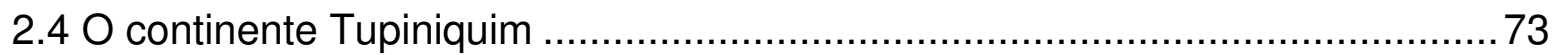

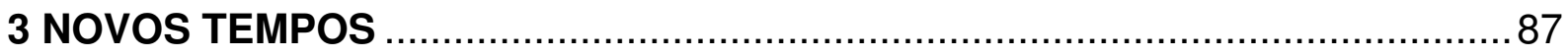

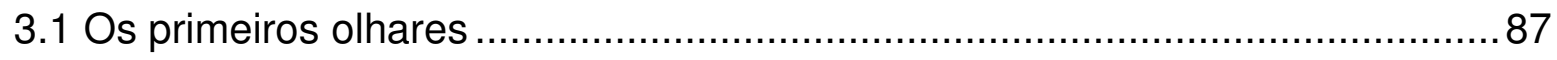

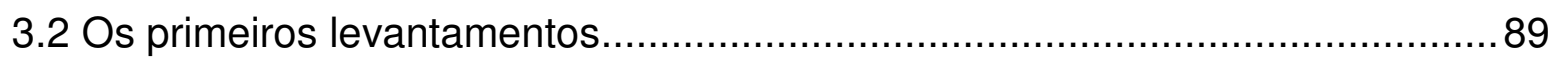

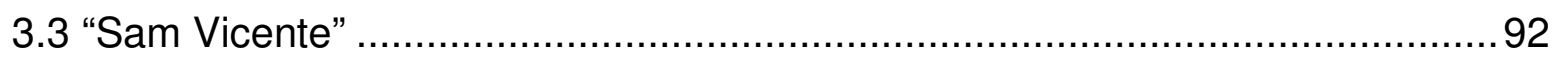

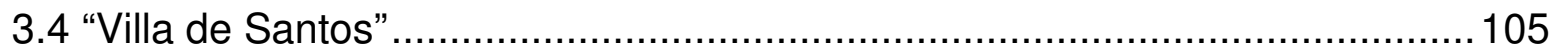

3.5 “São João Batista de Cananéia" ..................................................... 121

3.6 "Villa de Nossa Senhora das Neves de Iguape".................................. 137

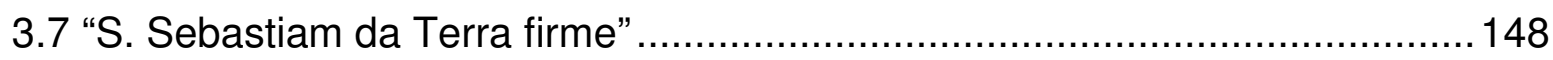

3.8 "Vila Nova da Exaltação da Santa Cruz do Salvador de Ubatuba" .................162

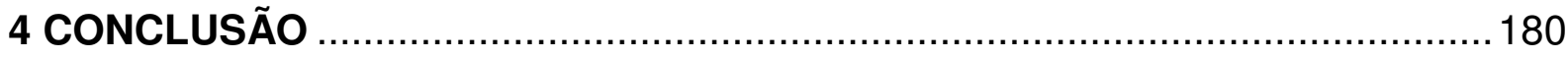

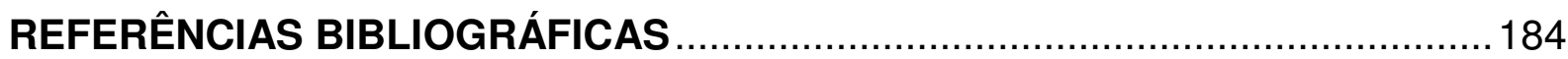

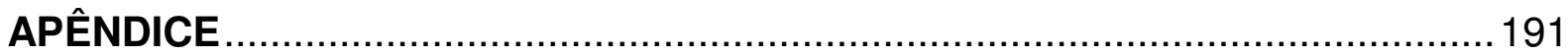




\section{INTRODUÇÃO}

Paisagens litorâneas são plenas de significados. Palco do eterno conflito entre as grandes massas de água e terra, as linhas costeiras desenham as feições do mundo. Esses alinhamentos, em oposição às amplitudes interiores, continentais e oceânicas, são territórios de espectro diferenciado. Nem mesmo a diversidade de relevos, vegetações e climas dos cenários de beira-mar comprometem o contraste global abstraído nos seus seqüenciamentos: a interação de dois universos. Seus traços, como riscos de giz no chão, determinam o habitat do homem, demarcam seus limites supremos. Nesses espaços, ou melhor, nesses lugares, as concentrações humanas talvez sejam resposta a esta interação, em todos os tempos. Povos de natureza distinta, em localidades diversas, vivenciaram a costa e emprestaram seus olhares aos horizontes do insondável. Decerto, submetidos aos rigores do limite, se não puderam avançar, beneficiaram-se de seus atrativos, de suas riquezas ambientais. Ademais, essas bordas sempre foram dinâmicas: as variações do nível dos mares, por movimentações geológicas ou ciclos milenares, certamente comprometeram o status da paisagem. Novos tempos, novos domínios. Novos olhares, novas percepções. A marinha, de qualquer forma, por seu balizamento geográfico, sempre foi um referencial distinto para as populações que a ocuparam. Alguns podem tê-la alcançado em migrações seculares, provenientes de regiões interioranas; outros, talvez, percorreram seus alinhamentos ao se estabelecerem. Outros, ainda, alcançaram-na após travessias oceânicas ou insulares. $O$ fato é que sociedades de natureza diversa elegeram esta particularidade geográfica como seu lugar de vivência, em épocas e localidades distintas ou não. Estabeleceram seus territórios e escolheram seus sítios. 
Integraram-se no habitat e interagiram nos nichos ecológicos. Criaram afinidades, elos afetivos com os seus lugares, com o seu ambiente (TUAN, 1980). Em comunhão com suas vivências desenvolveram percepções, atitudes e valores diferenciados, próprio da arquitetura de suas paisagens. De acordo com observações da geógrafa Lucy Marion Machado,

A superfície da Terra é elaborada para cada pessoa pela refração por meio de lentes culturais e pessoais, de costumes e fantasias. Todos nós somos artistas e arquitetos de paisagens, criando ordem e organizando espaços, tempo e casualidade, de acordo com nossas percepções e predileções. (MACHADO, 1986, p. 97).

Com estes horizontes aproximamo-nos do continente sul-americano. Ainda sabemos muito pouco sobre as superfícies terrenas do mundo, muito menos sobre os oceanos. Simbolicamente, traduzimos com certo rigor os desenhos da Terra há pouco mais de duzentos anos, ao certificarmos as posições de longitude só no final do século XVIII, conforme nos informa a historiadora Beatriz Piccolotto Siqueira Bueno (BUENO, 2003). Todavia, a trajetória das ocupações humanas precedeu em centenas de anos o recorte histórico clássico, de olhar ocidental, conhecido como Idade Moderna e que enquadra o processo da Expansão Marítima como hegemônico no surgimento das vilas litorâneas objeto de nosso estudo. Aqui, como em outras porções do Novo Mundo, a expansão européia encontrou outros povos, outras nações. Em nosso caso, os adventícios portugueses souberam de imediato o que enfrentariam ao conhecer os novos domínios, partilhados alhures. Um leque de necessidades, interesses e atitudes permeará as ações destes ibéricos na consolidação da sua colônia. Necessariamente comprometerão a significativa presença das populações indígenas que habitavam primordialmente a imensidão. Os nativos, por sua vez, sabiam menos sobre as conseqüências dos primeiros contatos, mesmo porque, nos primeiros trinta anos, foram pontuais e esporádicos. 
Quando se intensificaram, a partir das instalações coloniais, não demorou muito para entenderem que seu destino estava traçado.

A linha costeira, determinante do limite geográfico, também foi linha do encontro de culturas tão distintas. Os povos indígenas que ocupavam a costa, conforme o antropólogo Darcy Ribeiro, "[...] eram principalmente tribos de tronco tupi que, havendo se instalado uns séculos antes, ainda estavam desalojando antigos ocupantes oriundos de outras matrizes culturais. Somavam, talvez, 1 milhão de índios [...]" (RIBEIRO, 1995, p. 31). Ao que se sabe, migraram de regiões centrais do continente, veremos adiante. Assistiram, portanto, a chegada de embarcações ádvenas emergindo dos horizontes marinhos em sua direção.

Os caminhos percorridos pelos navegadores foram muito maiores do que suas travessias. A expansão marítima foi um processo centenário, evidentemente atrelado ao contexto histórico mercantilista. No século XV e XVI, principalmente, ampliam-se significativamente os horizontes europeus. O território global, ou a superfície do nosso supremo espaço de vivência, a Terra, passa a ser integralmente conhecida e partilhada. Um novo desenho do mundo compõe o ideário da Idade Moderna. 0 homem ocidental alcança novos limites, compreende sua magnitude e incorpora ao seu repertório de conhecimentos e interesses novas dimensões, novas paisagens. Mas a complexidade do trânsito do medievalismo para a modernidade, no que competiu aos navegadores, não foi tarefa fácil: além da precariedade das embarcações e adversidades dos oceanos, precisaram vencer o imaginário dos seus temores.

Não havia mar no Paraíso. As referências bíblicas, balizadoras do pensamento dos homens ocidentais durante séculos (e que perduram até hoje), legaram aos mares "As raízes do medo e da repulsa" (CORBAIN, 1989, p. 11). O 
historiador francês Alain Corbain, referindo-se às imagens diluvianas contidas na obra Teoria da Terra, de Thomas Burnet - 1684, escreve que, após a punição divina,

O mar atual não é senão este grande abismo novamente encadeado por Deus; sua bacia, seus litorais, as montanhas que o delimitam, datam do dilúvio; constituem "o mais pavoroso espetáculo oferecido pela Natureza. (CORBAIN, 1989, p. 14).

Soma-se a esse repertório de imagens o incompreensível, o incognoscível e o caráter demoníaco do mar. Marinheiros portugueses e espanhóis do século XVI lançam relíquias nas ondas para apaziguar as tempestades; missionários jesuítas entregam-se a orações, ocasião dos arrependimentos, nos contratempos das viagens costeiras brasileiras. Os inúmeros feitos e conquistas da nova geografia do

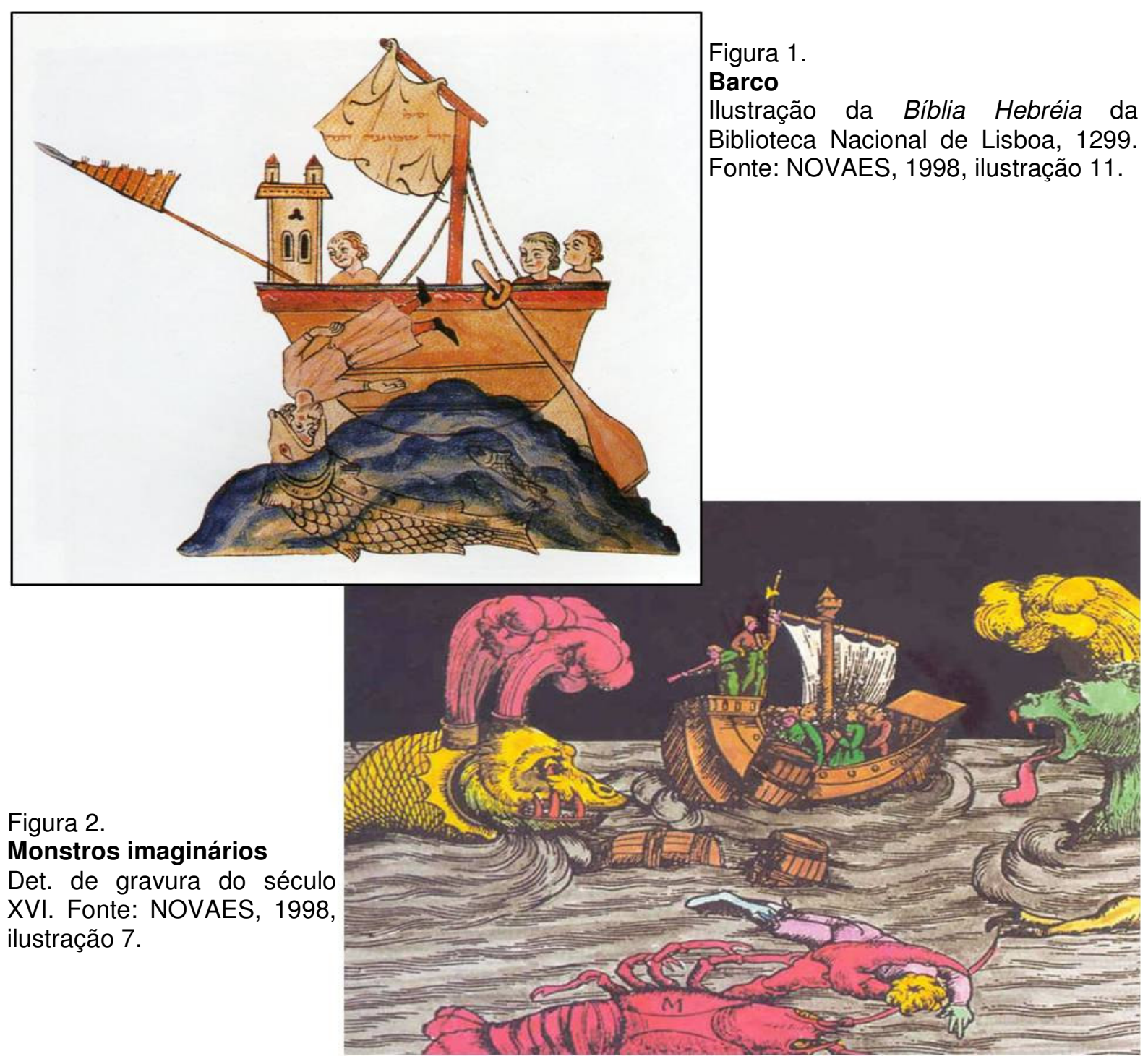


mundo foram acompanhados de implacáveis histórias trágico-marítimas (BRITO, 1971). A precariedade e insalubridade das embarcações, os naufrágios, fomes, medos, doenças e conflitos vivenciados nas travessias, amplamente retratados pela historiografia, certamente contribuíram para compor o repertório de impressões dos que viajaram, migraram e produziram espaços nos novos domínios.

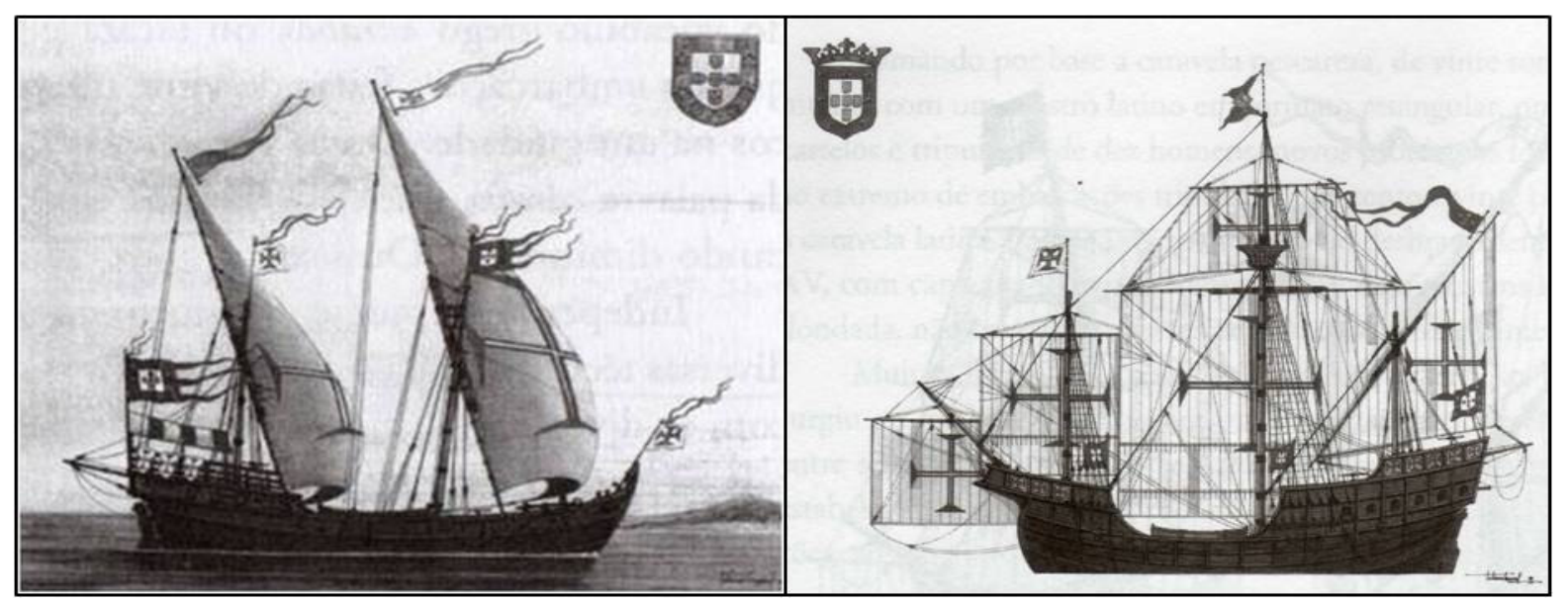

Figura 3. Caravela e Nau (d). Avanços decisivos para as navegações no século XV. Fonte: RAMOS, 2004, p. 50 e 52.

Inerente ao expansionismo, a assimilação de novas tecnologias náuticas permitiu o seguimento dos grandes descobrimentos e conquistas. Entre as embarcações, as caravelas foram fundamentais no rompimento das águas do Atlântico meridional. É que para se navegar ao sul percorrendo a costa africana, os ventos e correntes marítimas predominantes são contrários; o mesmo acontece ao longo da costa do Brasil no sentido inverso. Nesta região intercontinental, estas forças naturais configuram um regime de circularidade anti-horária. São condições ambientais, é preciso ressaltar, relevantes ao expansionismo, principalmente para o alcance das Índias. As costas oeste africana e leste brasileira estarão naturalmente envolvidas com a logística dessas viagens, somadas aos rumos da bacia do Prata e do Pacífico (Figuras 4 e 5). Com suas velas latinas e sua conformação esbelta, a 
caravela é resposta tecnológica à necessária navegação nos contraventos do sul da faixa equatorial, inicialmente na costa africana. Conforme o historiador Fabio P. Ramos, eram ágeis na "[...] habilidade para navegar em zigue-zagues sucessivos [...]" (RAMOS, 2004, p. 49). Apesar da pouca capacidade de carga e artilharia, "[...] a eficiência e agilidade das caravelas, sobretudo em viagens curtas e médias, tornaram-nas ideais para utilização na rota do Brasil." (RAMOS, 2004, p. 49). A demanda pelo transporte de maior capacidade de carga e artilharia foi suprida com o desenvolvimento da nau (Figura 3) pela indústria naval portuguesa. Mais pesada, sem a mesma capacidade de manobra, todavia, prestava-se aos percursos mais longos, onde estavam as fontes de intensificação do comércio. Necessariamente, portanto, adequavam-se às estações e rumos dos ventos. A costa brasileira, balizadora natural da Carreira da Índia e do cone sul americano, incorpora-se no repertório referencial dos novos lugares do mundo. A Viagem do Descobrimento é bastante representativa deste contexto. O discutível acaso da

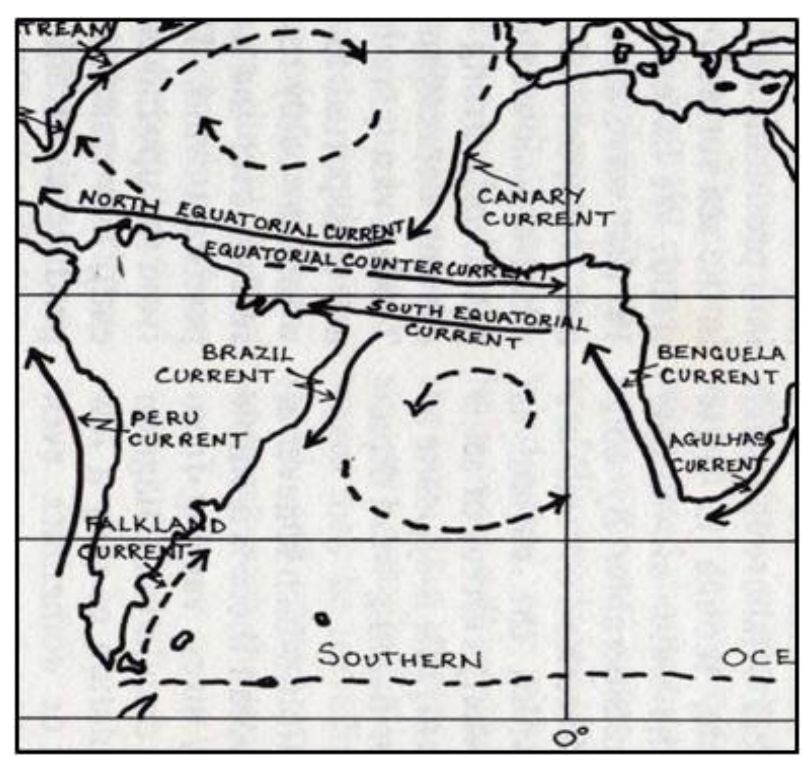
descoberta associou-se à busca de Figura 4. As correntes. Principais vias no melhores monções, adjacentes aos Atlântico Sul. Fonte: SANDERSON, 1982, p. 122, detalhe do diagrama 75.

nossos limites costeiros (Figura 5, p. 16). Este quadro decerto também justifica as atividades pioneiras do nosso degredado Bacharel entre São Vicente e Cananéia no início do século XVI. Prestava serviços de reparos e abastecimentos às esquadras que por ali passavam. Além das caravelas e naus, mais documentadas na 
historiografia, diversas tipologias de embarcações também foram desenvolvidas pelos portugueses, atendendo à amplitude de suas "Conquistas". (RAMOS, 2004).

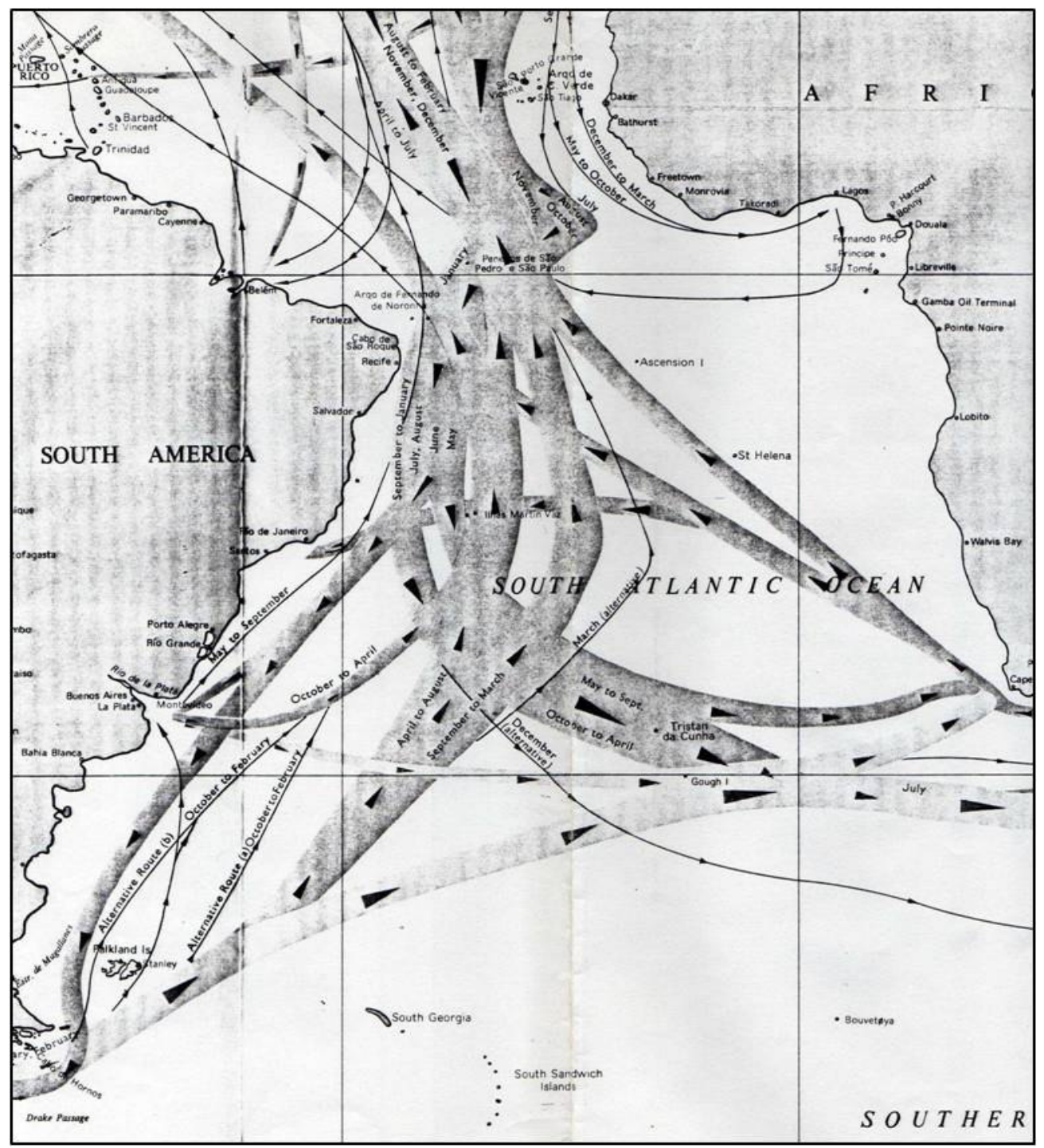

Figura 5. Os ventos. Esquema das rotas e períodos favoráveis à navegação a vela na região. Ventos e correntes predominantes traduzem a lógica da passagem das esquadras junto à costa brasileira a caminho das Índias e do cone sul da América. Fonte: Ocean Passages for the World (NP 136). Taunton, UK: Hydrographic Department, 1974. Detalhe da carta The world sailing ship routes.

A expansão marítima pelo Atlântico Sul também demandou avanços tecnológicos nos instrumentos de navegação. $O$ mais significativo foi 0 aprimoramento do astrolábio para as medições diurnas da altura do sol. "Instrumento de observação noturna, provavelmente de origem grega, datando do século II ou III, o astrolábio era um disco circular feito de bronze com um indicador em forma de 
agulha fixado ao centro, e uma série de números gravados na borda." (SEED, 1999, p. 161). A historiadora Patricia Seed também nos informa que as cortes portuguesas do século $X V$, entre o infante D. Henrique, "o Navegador", e mais tarde os reis D. Duarte, D. João II e D. Manuel, "[...] valeram-se de astrônomos judeus como Jacob ben Abraham Cresques, dos irmãos Moisés e José Vizinho e de Abraham Zacuto (Zakkut) para criar soluções baseadas na astronomia." (SEED, 1999, p. 159). Entre elas, traduzir as posições de latitude pela altura do Sol. Foi a melhor solução para se navegar onde os céus noturnos ainda não eram conhecidos como no hemisfério Norte. Além do que, simplificava-se o sistema de navegação em uma única constante para os dois hemisférios. A singularidade do instrumento surpreende pelo papel que representou na consolidação do Novo Mundo (Figura 6, p. 18). Segundo Seed,

[...] os portugueses alteraram o desenho do astrolábio, de modo que, quando suspenso por um braço esticado à altura da cintura e com a agulha apontando para o Sol, este passasse através de dois pequenos orifícios em pequenos quadrados presos às extremidades inferior e superior da agulha. Isso produzia um pequeno círculo de luz (contra a sombra dos quadrados), que incidia sobre os números, indicando a altura do Sol acima do horizonte (altitude solar). A técnica, chamada "pesar o Sol", evitava o problema de ter que olhar diretamente para o astro, como teria sido necessário usando-se 0 tradicional astrolábio noturno. (SEED, 1999, p. 162).

Após a leitura em graus, entre o horizonte e o astro, tendo-se o observador como vértice (medição obtida especialmente na passagem meridiana do Sol, quando este atinge a maior altura no arco do seu trânsito, em torno do meio-dia), cálculos matemáticos permitem a obtenção da posição da latitude. Citado acima, o astrônomo Zacuto criou, por volta de 1484, um manual conhecido como Regimento do astrolábio, composto de diversas tabelas que sistematizavam a prática. Tornouse a base da navegação portuguesa em seus percursos oceânicos. "O Regimento foi 
posteriormente copiado por outras nações européias, entre as quais incluem-se a Inglaterra e a Holanda [...]" (SEED, 1999, p.166). A perda da liderança científica

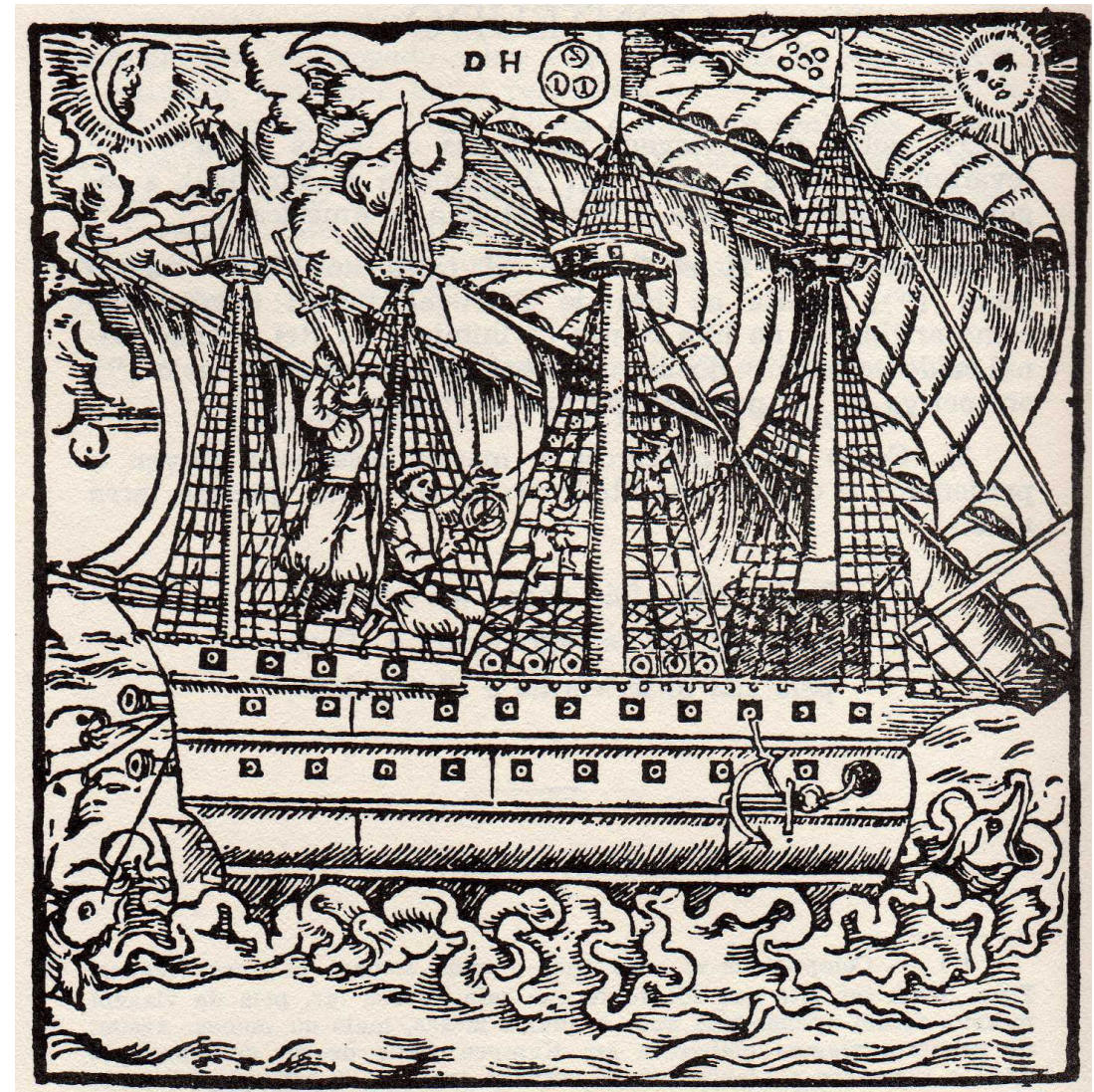

Figura 6. Alturas do céu. $O$ astrolábio e a balestilha iluminam caminhos e certificam posições. Xilogravura do livro original de Hans Staden, de 1557. Fonte: STADEN, 1974, p. 38

portuguesa na expansão marítima é atribuía por Seed às pressões que o catolicismo exerceu nos judeus ibéricos a partir do final do século XV, como no exílio de Zacuto.

As leituras do céu manifestaram-se em desenhos que nortearam a conquista o mundo. Quando os olhares não alcançaram mais os horizontes dos anseios, os limites ponderáveis do incognoscível traduziram-se em representações, abstrações por vezes antecipadas dos domínios. A trajetória do conhecimento parece proceder do universal. Antes de conhecer a extensão territorial do seu maior lugar de vivência, a Terra, o homem conviveu com sua condição cósmica: o superior. O manto do céu sempre acobertou suas indagações, sua devoção, antes que tivesse condições de compreendê-lo. Houve um longo percurso até que o mundo pudesse reduzir-se na 
espacialidade da esfera, na tridimensionalidade da malha de circunferências delineadoras do globo, referenciadas ao cosmo, ao movimento cíclico do universo aparente: marcas inexoráveis do tempo. Talvez tenham sido os primeiros traços da razão mensuráveis enquanto expressão de comunicação ambiental. A concepção do universal foi condição para conquistá-lo. Os enquadramentos continentais e as amplitudes oceânicas, antes indagações do

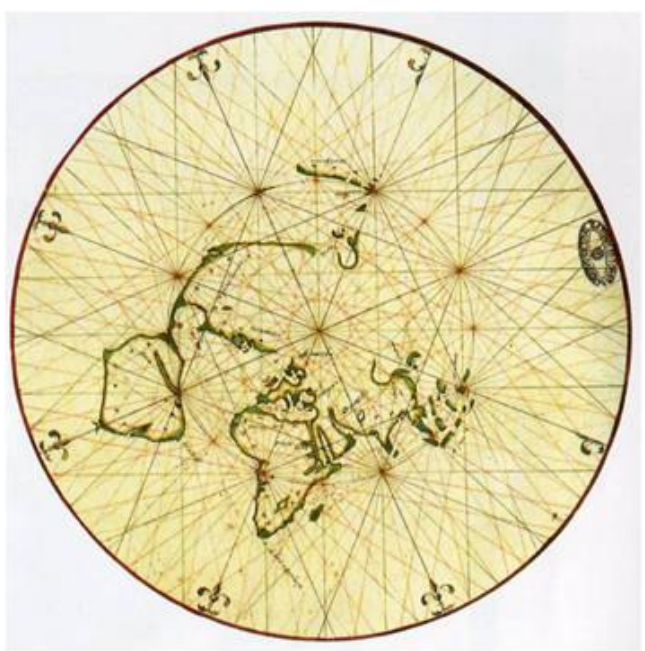

Figura 7. Esboço da Terra. Atlas anônimo de c.1560 do Livro de marinharia de João de Lisboa. Lisboa, Torre do Tombo. Fonte: NOVAES, 1998, ilustração 15

imaginário, materializaram-se em mapas e planisférios reveladores dos novos domínios, certificadores das grandes partilhas nacionais. Foram assinaladas as localizações dos novos territórios, dos novos núcleos urbanos, das fortificações e dos portos; o instrumental que serviu às medições astronômicas para as navegações servirá às mensurações dos sítios, dos domínios em terra (BUENO, 2003): apropriação simbólica dos conhecimentos do céu assinalados no solo, na certificação de localidades em cartas, devidamente referenciadas nos endereços globais de latitude e longitude. A expansão marítima, com a matemática dos astros, redesenhou o mundo moderno. Sob olhares europeus. 


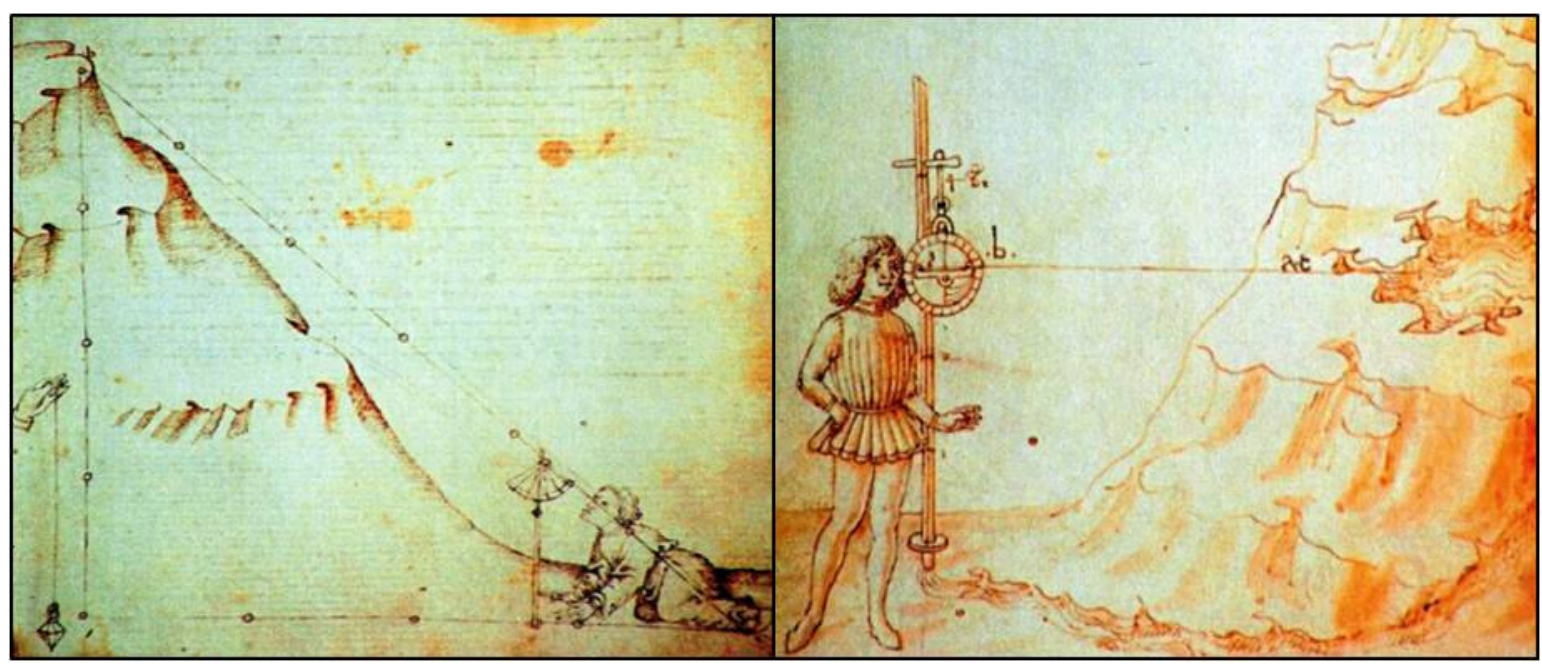

Figura 8. Alturas da terra. Instrumentos náuticos adaptados aos levantamentos topográficos. Fonte: BUENO, 2003. Det. de desenhos de Mariano Taccola, século XV.

Da mesma forma que os alinhamentos costeiros estabelecem limites claros entre universos geográficos tão distintos, terras e mares, a linha do tempo da história brasileira procura determinar a marcante chegada do europeu em nossas paragens como evento primevo. Àquela data limite é atribuída a gênese da sociedade brasileira. Não deixa de ser uma racionalização do universo temporal, tantas vezes traduzido para nossa compreensão em períodos, eras, ciclos, ritmos e outras dimensões equalizadas com o universo físico. Porém, limites rígidos estabelecidos no tempo talvez não sejam próprios a processos sócio-culturais. A temporalidade progressiva pode ser uma armadilha quando temos que resgatar as dinâmicas do passado. Analogias à parte, nossa linha litorânea assistiu ao encontro determinante entre os habitantes primitivos e os adventícios ibéricos. De fato, a partir dos contatos, desenharam-se novas paisagens sociais e as sociedades envolvidas, entre dominados e dominadores, nunca mais foram as mesmas. Os novos contextos não aniquilam o passado, como induz o limite temporal. Ao contrário, reestruturam-se novos grupos sociais que perpetuam os repertórios culturais de suas vertentes. Portanto, se intencionamos examinar o recorte histórico da formação das vilas 
litorâneas escolhidas, será fundamental "[...] a análise dos processos sociais e culturais do passado [...]" (FUNARI, 2007, p. 50). A distinção metodológica entre a pré-história e a história no Brasil, especialmente cristalizada na data do descobrimento, respeita tradições que sempre distinguiram essas áreas de estudo como sociedades sem escrita e com escrita. Todavia, ressalva o historiador Pedro Paulo Funari:

\begin{abstract}
A história das sociedades européias ("nosso" tipo de sociedade), contrapondo-se às sociedades dos outros (o tipo de sociedade "deles"), foi sempre realçada por uma ênfase na história escrita. A distinção entre sociedades com escrita e aquelas sem escrita exerceu um papel importante nas ciências humanas, e se agregava a outras dicotomias como: mito|história, barbárie|civilização, primitivo|avançado. Essas dicotomias enquadraram nossa compreensão da evolução social e da história da humanidade desde, ao menos, o século XVIII, e seu poder é tamanho que elas continuaram a dominar as tradições a-histórica, funcionalista e estruturalista do início até a metade do século XX. (FUNARI, 2007, p. $50)$.
\end{abstract}

Adiante, Funari adverte: "O uso de dicotomias etnocêntricas, como não letrado|letrado, mito|história, primitivo|avançado, na estruturação da análise histórica retarda a produção de histórias alternativas." (FUNARI, 2007, p. 51). Esta elucidação metodológica contribui às novas perspectivas de estudos sobre nossa formação social.

Recentemente alguns trabalhos procuram resgatar a real importância das populações nativas no processo histórico brasileiro. São interpretações críticas das posturas historiográficas que quase sempre relegaram a estas sociedades o papel de coadjuvantes, quando não, omitiram-nas. Não faltaram razões a esta parcialidade, sedimentada ao sabor dos dominadores: ou consideravam a inferioridade racial e defasagem evolutiva, ou enalteciam o bandeirismo ou, ainda, entre outras razões, privilegiavam as fundamentações econômicas do colonialismo 
de matriz européia e produção periférica, com os espaços e a sociedade respondendo a este recorte conjuntural.

Destacamos o título Negros da terra: índios e bandeirantes nas origens de São Paulo, tese de doutorado defendida pelo historiador John Manuel Monteiro (1994), publicada em livro, que faz uma releitura sistemática dos quadros sociais que formaram a sociedade paulista. O autor procura questionar as tradições enraizadas na historiografia, que sempre minimizaram as vertentes indígenas na composição societária, não só de São Paulo, mas de todo o Brasil: "[...] se as bandeiras paulistas passaram a ocupar um lugar de destaque na historiografia brasileira, a sociedade que se constituiu a partir destes empreendimentos ainda permanece, na verdade, pouco conhecida." (MONTEIRO, 1994, p. 8). A seguir, reitera:

Com certeza, atrás das façanhas destes intrépidos desbravadores esconde-se a envolvente história de milhares de índios - os negros da terra - aprisionados pelos sertanistas de São Paulo. [...] Ao mesmo tempo, a imensa bibliografia sobre a formação da sociedade e economia coloniais tem dedicado pouca atenção ao papel do trabalho indígena. Apesar de algumas contribuições recentes terem lançado luz sobre este tema negligenciado, as principais tendências no estudo da Colônia permanecem subordinadas a um quadro teórico no qual a organização do trabalho se atém à lógica da expansão do capitalismo comercial. (MONTEIRO, 1994, p. 8).

Em artigo oportuno, denominado Historiadores e cronistas e a paisagem da colônia Brasil, a historiadora Dora Shellard Corrêa (2006) retoma os mesmos questionamentos, mais próximos ainda dos objetivos de nossa pesquisa. Reporta-se às crônicas do primeiro século, onde os registros dos espaços das ocupações indígenas evidenciam uma amplitude que foi ignorada pela historiografia, especialmente por Capistrano de Abreu e Caio Prado Jr. que, segundo a autora, "[...] utilizam predominantemente fontes do século XIX." (CORRÊA, 2006, p. 69). As fontes referem-se aos cronistas viajantes que, evidentemente, não encontraram as 
significativas configurações sociais do período primevo. Para Corrêa, os historiadores citados,

[...] apesar de metodologicamente e teoricamente, portanto politicamente, apresentarem visões antagônicas, suas descrições da paisagem colonial se aproximam. Comungam, por questões diversas, a incapacidade dos índios em transformarem a natureza, em serem sujeitos da história, seja por sua inferioridade racial ou por encontrarem-se num estágio defasado de evolução sócio-econômica. [...] Consciente ou inconscientemente obscureceram a ação indígena. Ocultaram dessa paisagem a exposição das aldeias e a interferência indígena na natureza, embora tivessem informações para construir outro quadro. Os cronistas coloniais expuseram esses dados. (CORRÊA, 2006, p. 69).

Em outro trecho do ensaio observa que muitas vezes, até hoje, reproduzimos representações falsas e parciais da paisagem colonial, e comenta oportunamente: "Ignoramos os passos iniciados por Sérgio Buarque de Holanda, o qual, desde a edição de Monções (1945), apresenta um cenário diverso, uma outra visão da fronteira." (CORRÊA, 2006, p. 67).

Em Caminhos e Fronteiras, com primeira edição em 1957, Holanda (1994) reúne um conjunto de monografias sobre a formação e vida dos habitantes de São Paulo. Observa com minúcias os hábitos e costumes dos ocupantes dessa porção territorial, identificando traços da interação cultural entre indígenas e portugueses. Nesse caso, o cenário social é representado não só pelas atividades econômicas, mas pelas manifestações dos repertórios culturais envolvidos. Em ensaios como Veredas de pé posto, Samaritanas do sertão, Caça e pesca e Uma civilização do milho, entre outras, o historiador destaca como as vivências de tradição indígena estavam incorporadas à sociedade dos mamalucos. Contudo deixa transparecer que suas análises são referenciadas no universo europeu. Estudo anterior denominado Raízes do Brasil, publicado em 1936, tornou-se um clássico de nossa historiografia. Neste livro, Holanda (1971) investiga aspectos históricos e antropológicos de nossa formação; aborda os traços culturais portugueses e de outras linhagens européias, 
bem como dos ameríndios e africanos, tentando fundamentar a natureza da brasilidade. Percorre os caminhos sinuosos das caracterizações raciais, reconsiderados posteriormente pelas ciências sociais e outras áreas do conhecimento. No prefácio da edição estudada, Antônio Cândido observa que: "Raízes do Brasil é construído sobre uma admirável metodologia dos contrários [...]. Em vários níveis e tipos do real, nós vemos o pensamento do autor se constituir pela exploração de conceitos polares." (HOLANDA, 1971, P. xiv). Observa-se isso claramente no capítulo IV, O semeador e o ladrilhador. Quando o autor estuda as formações urbanas brasileiras, do ponto de vista da ação portuguesa, alinha inevitavelmente comparativos com as instalações espanholas no mesmo continente, destacando seus critérios de regularidade. Neste momento, a metodologia dos contrários torna-se armadilha e os filtros culturais, talvez ancorados em tradições racionalistas, levam o autor a citar a palavra "desleixo" referindo-se à produção portuguesa:

\begin{abstract}
A cidade que os portuguêses construíram na América não é produto mental, não chega a contradizer o quadro da natureza, e sua silhuêta se enlaça na linha da paisagem. Nenhum rigor, nenhum método, nenhuma previdência, sempre êsse significativo abandono que exprime a palavra "desleixo" - palavra que o escritor Aubrey Bell considerou tão tìpicamente portuguêsa como "saudade" e que, no seu entender, implica menos falta de energia do que uma íntima convicção de que "não vale a pena..." (HOLANDA, 1971, p. 76).
\end{abstract}

À parte a generalização e abordagem semântica, ressalve-se sua sensibilidade quanto à inserção ambiental. Mais ainda, a citação a seguir registra o mérito do autor em identificar as representações urbanísticas do colonialismo com muita propriedade, considerando a pluralidade dos seus horizontes de pesquisa e a obscuridade das fontes iconográficas daqueles tempos:

É verdade que o esquema retangular não deixava de manifestar-se no próprio Rio de Janeiro já surge um esbôço - quando encontrava poucos empecilhos naturais. Seria ilusório, contudo, supor que sua presença resultasse da atração pelas formas fixas e 
preestabelecidas, que exprimem uma enérgica vontade construtora, quando o certo é que precedem, em sua generalidade, dos princípios racionais e estéticos de simetria que o Renascimento instaurou, inspirando-se nos ideais da Antigüidade. Seja como fôr, o traçado geométrico jamais pôde alcançar, entre nós, a importância que veio a ter em terras da Coroa de Castela: não raro o desenvolvimento ulterior dos centros urbanos repeliu aqui êsse esquema inicial para obedecer antes às sugestões topográficas. (HOLANDA, 1971, p. 75).

Encerrando as referências desta obra, retomando tratativas anteriores, destacamos um parágrafo contido na Nota 2 do capítulo citado, onde fica clara a percepção do autor sobre a interação cultural dos grupos sociais envolvidos após os contatos ocorridos em nossa frente atlântica:

Mas se é verdade que, sem o índio, os portuguêses não poderiam viver no planalto, com êle não poderiam sobreviver em estado puro. Em outras palavras, teriam de renunciar a muitos de seus hábitos hereditários, de suas formas de vida e de convívio, de sua técnicas, de suas aspirações e, o que é bem mais significativo, de sua linguagem. $E$ foi, em realidade, o que ocorreu. (HOLANDA, 1971, p. 75).

Segundo o geógrafo Aroldo de Azevedo (1957), o desenvolvimento das cidades brasileiras ocorre a partir de alguns vetores embrionários: os lugares fortificados ou postos militares; os aldeamentos indígenas; os arraiais e as corrutelas; os engenhos e usinas, fazendas e bairros rurais; os patrimônios religiosos e os núcleos coloniais; os pousos de viajantes e as estações ferroviárias. Diferencia aldeias de aldeamentos, estes associados a missões religiosas, ressalvando, sem muitas considerações, que as aldeias indígenas não podem ser consideradas embriões urbanos. Caracteriza especialmente o Patrimônio Religioso onde "[...] 0 proprietário de uma gleba escolhe certa área para doá-la ao santo de sua devoção através de documento público em que o beneficiário é a representação da autoridade eclesiástica [...]." O desdobramento desta devoção é um misto de fé com valorização das terras: "[...] fixa as bases do futuro aglomerado; atrai moradores para receita à diocese e arrendatários ou adquirentes de lotes do entorno; as receitas 
desenvolvem as igrejas e os núcleos: são sementeiras de cidades." (AZEVEDO, 1957).

A importância do patrimônio religioso na formação das cidades brasileiras também foi destacada pelo urbanista Murillo Marx (1991). No ensaio Cidade no Brasil terra de quem?, apresenta os perfis históricos dos arraiais, freguesias, vilas e cidades do Brasil do ponto de vista das questões fundiárias. Observa como a posse ou propriedade das terras, rurais e urbanas, são amparadas institucionalmente e juridicamente desde o Colonialismo até a República. Em seus registros sobre a gênese dos espaços urbanos, as ocupações pré-coloniais não são referenciadas. Na parte introdutória dessa obra, Murillo retoma um tema significativo para nossa pesquisa, que consta de sua tese de livre-docência apresentada em 1987 na Faculdade de Arquitetura e Urbanismo da Universidade de São Paulo. Publicada no livro Nosso chão: do sagrado ao profano (MARX, 2003), retrata o significado dos edifícios religiosos na paisagem urbana. Mostra como sua arquitetura, entre o espaço edificado e os vazios do seu entorno, especialmente o adro, é delineadora da articulação urbana. São referenciais históricos e de comunicação ambiental dos núcleos urbanos. A laicização destes espaços, segundo o autor, é inexorável pela mudança do perfil da relação Estado/lgreja ao longo da história brasileira. Este texto contribuirá para o estudo das vilas litorâneas.

Para finalizar esta exposição sobre algumas pesquisas teóricas, destacamos a obra Evolução Urbana do Brasil por sua especificidade temática. Este trabalho foi elaborado pelo Prof. Dr. Nestor Goulart Reis Filho (1968) para ser apresentado como tese no concurso de livre-docência da Faculdade de Arquitetura e Urbanismo da Universidade de São Paulo em 1964. Na Introdução o autor assinala que as formações urbanas brasileiras "[...] são parte de uma estrutura urbana - a rede 
urbana - que [...] está sujeita a um processo de origem social - processo de urbanização [...]" (REIS FILHO, 1968, p. 15). Adiante fundamenta um dos seus principais critérios de análise:

1 - Encarar o processo de urbanização no Brasil a partir de sua origem, ou seja, do processo de urbanização da Europa medievalrenascentista e as ligações entre ambos como constituídas pela política de colonização e, como parte desta, pela política de urbanização de Portugal no Brasil. (REIS FILHO, 1968, p. 23)

Com essa afirmação o autor alinha-se com a historiografia recorrente, quando as leituras são atreladas aos referencias do centralismo europeu. Mesmo relevando o perfil social dos processos urbanos germinais, desconsidera a presença ou interação indígena na constituição e consolidação dos núcleos e na articulação da rede. As poucas menções a estes povos nos ambientes referenciados são desvinculadas da ação dos agentes colonizadores na produção destes espaços. Na Primeira Parte estuda os aspectos sociais e históricos do sistema colonial e a política urbanizadora, até os enquadramentos da rede urbana; na Segunda Parte investiga os núcleos urbanos nos contextos espaciais, de sua abrangência territorial aos sítios de ocupação. A importância do trabalho está na adoção pioneira de critérios científicos e metodológicos de pesquisa num setor do conhecimento ainda árido de fontes textuais e iconográficas, que o autor esmerou-se em investigar e superar. É um documento angular da historiografia urbanística brasileira e ibérica.

O conceito de rede urbana, apresentado por Nestor Goulart, seguindo os passos dos geógrafos, contribuiu para delinearmos o escopo dessa dissertação de mestrado. Inicialmente pensávamos em analisar somente a cidade de Ubatuba, no litoral paulista, em função das relações afetivas que temos com a localidade, pois residimos ali durante alguns anos. Sabendo que voltaríamos os interesses para os percursos históricos, entendemos que a investigação centrada em apenas um 
núcleo urbano não faria sentido. Procuramos, sem perder o recorte litorâneo do atual Estado de São Paulo, estender o foco de pesquisa a outros núcleos urbanos para termos referenciais comparativos de análise. Desta forma foram eleitas as antigas vilas de São Vicente, Santos, Cananéia, Iguape, São Sebastião e Ubatuba, para compor o painel de estudos. O objeto de pesquisa, portanto, é um cenário regional. As cidades escolhidas apresentam diversidades evolutivas, como não poderia deixar de ser. Todavia, partilham especificidades, especialmente nos binários intrínsecos às suas posições geográficas, coincidentes com seus eventos embrionários. No litoral central temos São Vicente e Santos; ao Sul, Cananéia e Iguape e no litoral Norte, São Sebastião e Ubatuba.

O objetivo do trabalho, portanto, é investigar o universo de imagens, de representações e os processos históricos que nortearam a produção dos espaços urbanos no litoral paulista. A evolução do mestrado sugeriu novos horizontes de pesquisa: o contato com as fontes da Geografia Humana que privilegiam a percepção ambiental, diferenciando lugar de vivência de espaço físico, respeitando os elos afetivos que ligam as pessoas aos seus lugares, temáticas comunicacionais e ambientais, levou-nos a valorizar e a reconsiderar a importância dos povos indígenas na constituição da sociedade brasileira. É uma questão de lógica: se as produções urbanas são processos sociais, e se os contatos entre índios e europeus foram tão estreitos nos primórdios da colonização, as representações dos espaços produzidos, entre ocupações e articulações territoriais, necessariamente revelam o processo dinâmico desta nova paisagem social. Os indígenas não foram apenas coadjuvantes deste cenário. Houve, principalmente na região vicentina, uma inquestionável interação cultural entre poucos colonos portugueses e milhares de 
Tupiniquins, sem a qual os ádvenas não sobreviveriam e não lograriam êxito na fixação de suas primeiras instalações, rurais e urbanas.

Essas questões balizaram nossa investigação. Entendemos que, antes de estudarmos os aspectos físicos das produções urbanas, seria necessário pesquisar a constituição social e territorial dos povos que habitavam a região antes dos contatos com os europeus, temática afeta à Arqueologia. A intenção é fundamentarmos criteriosamente as informações sobre a natureza espacial de suas ocupações. Da mesma forma, será importante obter dos cronistas do século XVI, os registros fruto dos seus olhares. A estas vertentes de pesquisa, evidentemente, somam-se fontes historiográficas multidisciplinares. Além da História do Brasil e do Urbanismo, intrínsecos, e da Geografia e Arqueologia já citadas, observamos estudos pertinentes de Sociologia, Antropologia e de Comunicação Ambiental.

Os conteúdos da dissertação estão estruturados em seções da seguinte forma, além dessa INTRODUÇÃO: Na Seção 2, intitulada OS DONOS DA TERRA, abordamos temas do universo pré-colonial brasileiro, especialmente na caracterização das sociedades indígenas que habitavam a frente atlântica da região Sudeste do Brasil. Está dividida em quatro Subseções. A Seção 3, denominada NOVOS TEMPOS, dividida em oito Subseções, apresenta o exame específico dos núcleos urbanos elencados. Tentamos verificar as variáveis de suas gêneses entre a diversidade dos programas e as identidades sociais e ambientais. Nossa reflexão é referenciada por desenhos, cartografia antiga, fotografias e outras imagens que contribuem para a compreensão de suas representações. Não são meras ilustrações, mas fontes documentais de pesquisa, sobre as quais assinalamos desenhos e textos para evidenciar as informações. A Seção 4 é a CONCLUSÃo. 


\section{OS DONOS DA TERRA}

\subsection{Os caminhos das águas}

No quarto centenário da capital paulista, o antropólogo Egon Schaden informava que "Os colonos lusos que em 1532 vieram a São Vicente em companhia de Martim Afonso de Sousa não encontraram aqui uma terra desabitada." (SCHADEN, 1954, p. 386). O trecho, extraído originalmente de um artigo publicado no jornal $O$ Estado de São Paulo em 25-01-1954, por sua conotação, parece surpreender os leitores com uma realidade obscura do seu passado. De fato, para o repertório comum do nosso conhecimento, a história brasileira iniciou-se com a descoberta de nossas terras pelos portugueses. Alguns índios viviam aqui, sem dúvida, mas nunca mais se ouviu falar deles. Mais do que alertar sobre os domínios pregressos, Schaden descreve a pluraridade étnica que ocupava áreas do atual Estado de São Paulo. Veremos que diversos autores, da mesma forma, esmeraramse em caracterizar a paisagem social dos povos indígenas desta região, de cronistas e jesuítas do século XVI a pesquisadores atuais na área das ciências humanas.

As instalações embrionárias das vilas estudadas, antecessoras ou não de sua constituição jurídica, na linha do tempo correspondem, na maioria das vezes (veremos particularidades em Ubatuba e São Sebastião), ao evento que arqueólogos denominam de "contato euro-indígena" (SCATAMACCHIA; UCHÔA, 1993), ocorrido no século XVI. Dessa forma, podemos associar a produção germinal da arquitetura urbana dos núcleos à dinâmica social desencadeada a partir daquele encontro interétnico. Sobre os europeus, aqui estrangeiros, não faltam registros alinhados com a historiografia clássica. As fontes de pesquisa a respeito dos povos 
indígenas pregressos ao advento, todavia, enquadram-se metodologicamente nos estudos de nossa pré-história. Neste universo de investigação, procuramos a relevância de suas ocupações, locais e territoriais, na tentativa de caracterizá-las como indutoras dos processos urbanizadores subseqüentes.

Longos caminhos foram trilhados pelos povos de tronco Tupi, antes que ocupassem essa frente Atlântica e encontrassem um desafio ainda maior, que tornou-se insuperável: a dominação portuguesa.

$\mathrm{Na}$ escala da evolução cultural, os povos Tupi davam os primeiros passos da revolução agrícola, superando assim a condição paleolítica, tal como ocorrera pela primeira vez, há 10 mil anos, com os povos do velho mundo. (RIBEIRO, 1995, p. 31).

Estudos sobre ocupações humanas pré-coloniais na América do Sul atribuem ao istmo do Panamá a vertente dos fluxos migratórios que povoaram essa porção meridional. No livro A pré-história do Brasil, Pedro Paulo Funari e Francisco Silva Noelli (2005, p. 47) assinalam que: "A grande maioria [dos estudiosos] concorda (excetuando-se Beltrão e Guidon, como vimos antes) que a entrada do homem na América do Sul deu-se pelo istmo do Panamá há, pelo menos, 12 mil anos." Adiante, sobre a diversidade dos habitantes, os autores, "à luz da teoria de Walter Neves", sugerem que a ocupação humana do território ocorreu em três etapas:

A primeira etapa, ainda pouco conhecida, teria sido feita pelas populações paleoíndas [feições africanas e australianas] que predominavam em grande parte do Brasil até 12 mil AP ${ }^{1}$. A segunda etapa iniciou-se com a colonização mongolóide [feições asiáticas orientais], feita a partir do noroeste da América do Sul, que se espalhou mais rapidamente pelo litoral sul-americano, representadas pelas populações sambaquieiras, a partir de 10-9 mil AP, e mais lentamente pelo interior [...]. A terceira etapa teve origem com os povos mongolóides que originalmente se fixaram na Amazônia e criaram a agricultura, a cerâmica [a partir de 7 mil AP] e novos padrões demográficos e culturais de economia e organização social, a partir de 10-9 mil AP. (FUNARI; NOELLI, 2005, p. 63).

\footnotetext{
${ }^{1}$ AP - Antes do Presente, convencionado o ano de 1950 em referência à descoberta da datação por carbono-14 em 1952. Fonte: PROUS, 2006.
} 
O contexto desta terceira etapa é importante para os enquadramentos do nosso estudo. Veremos adiante que outros pesquisadores convergem na caracterização das ocorrências que antecederam a presença dos povos ceramistas/agricultores em nossa frente atlântica. Dessa forma, destacamos:

\begin{abstract}
Nesse longo período, especialmente entre 4 e 2 mil AP, segundo os arqueólogos Donald Lathrap e José Brochado, uma grande explosão demográfica na Amazônia causou a expansão geográfica de povos ceramistas e agricultores. Essa expansão ganhou impulso com 0 incremento da alimentação que a agricultura deu a essas populações. Junto com essa nova forma de subsistência foram desenvolvidas novas maneiras de se organizar social e politicamente (organização social mais hierarquizada e com lideranças definidas), com maior capacidade para conquistar e manter novos territórios. Essas novidades propiciaram uma vantagem geopolítica sobre as populações caçadoras-coletoras paleoíndias e mongolóides anteriores, que foram sendo gradualmente incorporadas, expulsas ou destruídas em seus territórios, cedendo lugar aos povos agricultores. Entendemos que a principal diferença foi o tamanho maior das populações agricultoras que pesou na disputa territorial, pois as evidências arqueológicas apontam para uma demografia menor nas populações caçadoras-coletoras. (FUNARI; NOELLI, 2005, p. 64).
\end{abstract}

Essas ações, segundo Funari e Noelli (2005, p. 65), transformaram "[...] o território brasileiro em um espaço em que passou a predominar a diversidade social e cultural entre os povos indígenas." Ainda, esta diversidade, amparada em pesquisas recentes, permite aos autores a formulação da "[...] hipótese de que não ocorreu, portanto, o desenvolvimento generalizado dentro dos parâmetros evolucionistas." (FUNARI; NOELLI, 2005, p. 70). Quanto à caracterização lingüística, ou "modelo lingüístico", uma língua original, o "proto-tupi”, deu origem a outras famílias lingüísticas. Acompanharam a diversificação social resultante do processo de expansão demográfica e territorial. Entre os desdobramentos, destacamos: "Os falantes das línguas tupinambás, da família tupi-guarani, ocuparam a maior parte da costa brasileira, entre o Ceará e São Paulo [...]" (FUNARI; NOELLI, 2005, p. 68).

Procuramos investigar, no campo da arqueologia, fundamentações científicas da interação ambiental dos assentamentos indígenas. É um suporte angular para a 
compreensão dos futuros seqüenciamentos urbanos. Veremos que os novos programas sociais não questionaram as escolhas pregressas, ao contrário, consolidaram-nas. Desta forma, não podemos deixar de citar observações como:

A agricultura, muitas vezes, seria a responsável por uma permanência definitiva dos assentamentos num mesmo local, mesmo quando em certas épocas do ano algumas parcelas da comunidade se afastavam para determinadas áreas em busca de mais caça, pesca, coleta ou lazer. Os assentamentos dos povos agricultores são comumente rodeados por uma série de locais menores, funcionando como áreas satélites, como os acampamentos nas roças, o porto das canoas, as áreas de extração de argila para cerâmica ou de pedras para confecção de artefatos e as áreas de coleta ou de caça. (FUNARI; NOELLI, 2005, p. 86).

Para finalizar as considerações sobre esta obra, transcrevemos a reflexão dos autores sobre o universo de pesquisa arqueológica alinhado com as diretrizes do nosso trabalho:

De um lado, essas afirmações abrem a perspectiva ainda pouco considerada pelos arqueólogos - assim como pelos próprios historiadores - que trata da participação efetiva das populações indígenas nos processos regionais de formação dos núcleos coloniais construídos pelos europeus. O que aconteceu? Quanta gente estaria envolvida nesses processos? Por exemplo, em áreas como a Baixada Santista, o litoral catarinense, o interior do Paraná, o litoral do Nordeste e a várzea do rio Amazonas, como foi o processo histórico que transformou territórios densamente povoados por indígenas em áreas tipicamente europeizadas? (FUNARI; NOELLI, 2005, p. 103).

Em dois livros, O Brasil antes dos brasileiros (2006) e Arqueologia brasileira (1992), o arqueólogo André Prous registra importantes estudos sobre o período pré-colonial, também baseado em pesquisas recentes. $\mathrm{Na}$ primeira publicação, assinala algumas datações indicativas da presença dos primeiros habitantes sul-americanos e ressalva que vestígios entre 12.000 e 8.000 anos atrás, inquestionáveis, "[...] ocorrem em várias partes do território brasileiro no período, o que significa que este já estava densamente ocupado." (PROUS, 2006, p. 25). Em outro capítulo da publicação, titulado $A$ onda tupiguarani (quando expresso sem 
hífen o termo refere-se à tradição cultural, segundo o autor), Prous elucida a associação lingüística designativa do padrão sociocultural das populações especialmente comprometidas com o processo colonial:

"Tupi" e "Guarani" são termos aplicados desde o século XIX pelos
pesquisadores a populações que falam línguas aparentadas; fazem
parte de um "tronco" lingüístico comum, chamado "tupi-guarani"
(escrito com hífen), da mesma forma que as línguas neolatinas atuais
derivam do latim. As línguas tupi (encontradas ao norte do estado de
São Paulo) e guarani (ao sul do rio Paranapanema) são muito
próximas entre si - como o espanhol e o português. Por isso são
chamadas Guarani as populações meridionais (que vivem hoje no
Paraguai, no Rio Grande do Sul e até no litoral de São Paulo), e Tupi
as populações do norte, embora elas usem outros termos para
designar a si mesmas. [...] No século XVI, os primeiros colonos e
missionários europeus notaram a existência de hábitos e crenças
comuns entre as populações que falavam essas línguas
aparentadas. (PROUS, 2006, p. 95).

Entre outros temas, é oportuna a referência do autor aos hábitos alimentares associados aos seus cultivares. Entre os Tupi, ressalva o consumo da mandioca. Sua farinha, misturada com o peixe moqueado, conserva-se por alguns dias, permitindo reservas alimentares nas circulações territoriais e nas expedições guerreiras. Da mesma forma, o milho, apropriado aos climas temperados, seria o cultivo principal dos Guarani. Observamos, todavia, que no planalto paulistano, território de predominância da tribo Tupiniquim, de tronco Tupi, o milho também era cultivado, ao que parece em abundância. Era fonte do assédio dos Tupinambá do Rio de Janeiro no período de sua colheita, em novembro, conforme descrição de Hans Staden (1974). Sérgio Buarque de Holanda (1994), baseado em ampla literatura, reitera as virtudes da gramínea na região. Staden, ainda, registra que portugueses vicentinos adquiriam farinha de mandioca dos Tupinambá, mesmo enquanto inimigos, parecendo haver carência da raiz tuberosa, embora de cultivo assimilado, nessa porção meridional. Parece aceitável, portanto, que a mandioca, 
base alimentar dos Tupi, ocorria especialmente do Rio de Janeiro em direção ao Norte do Brasil.

Em Arqueologia brasileira (1992), citada acima, também encontramos informações sobre os hábitos alimentares, contextualizados em suas interações ambientais. Quanto às complementações proteínicas, o autor observa: "Os indícios encontrados em escavações reforçam esta impressão de que a pesca tinha importância bem maior do que a caça." (PROUS, 1992, p. 407). Esta fonte alimentar talvez seja um dos principais vetores de escolha das localidades para os assentamentos, especialmente nos limites costeiros:

O conjunto mais favorável à captação alimentar é o das enseadas, baías e lagunas, contato entre o ambiente marítimo e terrestre, entre a água salgada e doce. Este fator favorece a escolha do local pelos seres aquáticos para a procriação. Numerosos peixes migratórios, como a tainha, procuram-no para desovar. [...] A penetração do ambiente marítimo dentro do continente torna vizinhos o campo, a mata e o mar, concentrando, num raio mínimo, recursos que, em geral, se acham separados. (PROUS, 1992, p. 202).

Estes atrativos ecológicos não favoreciam apenas o estabelecimento de aldeias. Quando não, por sua exuberância, acolhiam acampamentos de coleta, com nítido perfil sazonal, tal como ocorria na baixada vicentina. A beira-mar incorporada ao habitat dos Tupiniquim, sediados no planalto, era freqüentada especialmente nos meses do inverno, quando memoráveis cardumes de tainhas e paratis desovavam nesses estuários litorâneos, e o frio do planalto era mais rigoroso.

A pesca era praticada geralmente em grupo [...]. No momento em que cardumes migratórios passavam do mar para os rios para desovarem, faziam-se cercas de madeira para encurralar os peixes, que eram então capturados com as mãos ou flechadas; não há indícios de que os Tupis tenham usado redes de pesca, ao contrário dos Tapuias do interior, mencionados por Soares de Sousa. No mês de agosto, quando chegam os cardumes de tainha, os homens se empenham particularmente em sua captura, porque, transformadas em farinha, serão uma das bases de sustentação da expedição de guerra. (PROUS, 1992, p. 419). 
A diversidade ambiental dos territórios Tupi-Guarani, no entanto, apresenta

outras características que foram alinhadas por Prous. No contexto continental, segundo o autor, estes grupos:

[...] não se adaptaram às terras frias, de altitude ou de latitude: [...] em compensação, sempre são encontrados a curta distância dos rios navegáveis, em zonas de matas. Com efeito, o ambiente de $96 \%$ dos sítios é de mata pluvial litorânea, de mata pluvial tropical ou subtropical encontrada nos grandes vales meridionais ou nas zonas onduladas do Centro-Sul, ou ainda nas matas ciliares (que acompanham os rios) e no cerradão nas regiões algo mais secas. [...] Portanto, a ocupação corresponde à rede hidrográfica principal, como se fosse uma teia de aranha entre os fios da qual subsistiriam ilhotas abandonadas aos tradicionais habitantes da região que sobreviveram nos relevos, que os Tupiguaranis canoeiros não cobiçavam e onde evitavam aventurar-se [...]. (PROUS, 1992, p. 373).

Sobre a geografia da faixa costeira, característica do Sul-Sudeste, descreve:

Esta é separada do planalto por fortes escarpas resultantes de falhas e que constituem uma barreira de mais de mil metros de altura. Nestas condições, existem poucos vales importantes entre o rio Doce, ao norte, e o Jacuí, ao sul; os rios costeiros têm poucos quilômetros de extensão, originando uma sedimentação lodosa estritamente local. Dominam, portanto, as extensas praias arenosas formadas por sedimentação marítima, interrompidas por alguns afloramentos rochosos residuais que chegam até o mar. Estes originam ilhas a partir das quais formam-se restingas (flechas dunares no sentido das correntezas) que vão aos poucos isolando áreas lagunares rapidamente entupidas pelas deposições de lodo trazido pelos rios. A paisagem mostra, portanto, uma alternância de praias dunares retilíneas e enseadas que penetram profundamente entre as saliências rochosas. Logo atrás, antecedendo a serra do Mar, há uma região baixa, ocupada por sedimentos marítimos antigos e lagoas. As conseqüências disso são importantes tanto para a população atual quanto para os indígenas pré-históricos. Por exemplo, a obtenção da água doce se concentra ao redor de poucos pontos; a foz dos rios é afetada pela subida da água salgada na maré alta; é necessário subir bastante o curso do rio para se obter água doce, ou esperar pela maré baixa. Entretanto, as zonas de coleta alimentar mais favoráveis estão no curso inferior [...]. (PROUS, 1992, p. 200, grifo nosso).

Veremos que a restrição de água doce da citação pode ter sido angular, especialmente, na escolha dos sítios de São Vicente, Santos, Cananéia e Iguape. 
Na citação adiante, além de relevar a proximidade da água, condição vital, Prous aponta outras características ambientais determinantes dos sítios de ocupação:

Um dos elementos fundamentais para escolher um lugar para morar é a proximidade da água. Algumas populações têm também outras exigências: que haja rio navegável, ou terras férteis, ou uma mata, nas imediações. Neste caso, os lugares favoráveis são pouco numerosos e serão freqüentemente reocupados por populações que procuram as mesmas características. (PROUS, 1992, p. 37).

Aos rios navegáveis, mais significativos nas amplitudes do interior continental, associam-se as habilidades seculares destes povos canoeiros. Decerto estas águas são os grandes referencias do universo espacial Tupi-Guarani. Não foi diferente no planalto de Piratininga, bacia do alto Tietê. A citação a seguir, uma descrição sobre sítios de habitação, procura enquadrar a relação entre as ocupações e os rios:

\begin{abstract}
A localização das aldeias, pelo menos nos vales interioranos onde se concentra a maior população, obedece a um padrão bastante rígido: os sítios ocupam a parte superior das encostas de morros que dominam um rio principal navegável; geralmente, nas imediações das habitações, passa um córrego ou rio menor que fornece água potável. O rio maior, neste caso, costuma distar de várias centenas de metros a até um quilômetro. (PROUS, 1992, p. 376).
\end{abstract}

Evidentemente não pode haver rigidez no padrão de ocupação. Características específicas de cada ambiente e de cada grupo implicarão em diferenças na representação dos seus espaços. Componentes comuns, todavia, serão reveladoras das afinidades sócio-culturais que os grupos locais têm com a sua tribo. Além da paisagem das águas, o autor refere-se às trilhas indígenas, bastante significativas nas articulações territoriais e na consolidação do colonialismo: "[...] não se devem menosprezar outras vias de transporte, como os caminhos de terra perpendiculares ao eixo norte-sul da rede hidrográfica que punham em contato as terras do litoral com as do interior [...]" (PROUS, 1992, p. 374). Adiante, citando outro arqueólogo, Prous comenta sobre um dos mais importantes caminhos continentais, o Peabiru: 
Krone encontrou em Cananéia um machado de cobre cuja análise feita em laboratórios austríacos demonstrou a origem andina da matéria-prima. Mais recentemente arqueólogos encontraram vestígios de uma ramificação do mais famoso desses caminhos, o Peabiru dos cronistas, que ia justamente de Cananéia até o local onde fora fundada a cidade de Assunção. A via principal subia o vale do Ribeira até a nascente, cruzando depois o Paraná, onde atravessava as águas do Tibagi e do Ivaí, descendo depois o vale do Piquiri até o Paraná, saindo então do território brasileiro. (PROUS, 1992, p.374).

Quanto a espaços locais, o autor informa as áreas dos sítios, obtidos em pesquisas arqueológicas:

"[...] tentaremos avaliar os limites espaciais dentro dos quais os sítios costumam se encontrar. Os menores, formados por uma só concentração de material, têm a dimensão desta, entre 25 e $400 \mathrm{~m}^{2}$. Quando existe um conjunto, o sítio pode se estender por uma superfície de mais de $20.000 \mathrm{~m}^{2}$. No entanto é mais comum encontrar sítios entre 2.000 e $10.000 \mathrm{~m}^{2}$, a não ser nas regiões mais densamente ocupadas da bacia do Paraná e do litoral carioca. (PROUS, 1992, p. 378).

Contribui com informação relevante sobre a arquitetura dos abrigos quando se refere a alguns sítios Guarani: "Merece destaque a descoberta de barro com marcas de paus, indicando a utilização de taipa [...], comprovando a existência desta técnica já no período pré- colonial." (PROUS, 1992, p. 381). Adiante, em outro ambiente temático, menciona uma das manifestações da dinâmica interativa que estes povos mantinham com o meio ambiente. É uma ocorrência notável em vários registros históricos, principalmente nas crônicas e cartas jesuíticas. Refere-se à prática habitual e periódica das mudanças dos locais das aldeias:

Não parece haver dúvida de que cada tribo conservava-se dentro dos limites de seu território, não havendo nomadismo stricto sensu. No entanto, as aldeias mudavam freqüentemente de lugar, transferindo-se para lugares vizinhos, muitas vezes a menos de um quilômetro do local anterior. A justificativa dada pelos indígenas nunca convenceu seus ouvintes europeus: o gosto pela 'mudança de ar', conceito bastante estranho para pessoas procedentes de uma civilização urbana. (PROUS, 1992, p.416). 
Da Conclusão desta obra, onde Prous faz Um balanço da arqueologia brasileira, selecionamos:

A primeira constatação é de que não existe, no Brasil nem nas Américas, vestígios de homens pertencentes a uma espécie ou subespécie diferente da nossa. Só foram encontrados representantes de nossa humanidade: Homo sapiens [...]. Conseqüentemente, já que os indígenas pertencem à mesma sub-espécie nossa, eles possuem as mesmas capacidades fisiológicas e psíquicas de qualquer outra população do Velho Continente. Devemos aceitar o fato de que têm as mesmas virtualidades que as pessoas portadoras da chamada cultura ocidental que os estudam: não são inferiores nem superiores, nem piores nem melhores [...]. (PROUS, 1992, p. 565).

A seguir, consideramos outro importante estudo sobre o período pré-colonial brasileiro. Trata-se da Tese de Doutorado apresentada ao Departamento de Antropologia da Faculdade de Filosofia Letras e Ciências Humanas da Universidade de São Paulo, em 1990, denominada A tradição policrômica no leste da América do Sul evidenciada pela ocupação Guarani e Tupinambá: fontes arqueológicas e etno-históricas, defendida pela arqueóloga Maria Cristina Minero Scatamacchia. Este trabalho caracteriza as áreas de distribuição do complexo cultural Tupi-Guarani. Fundamenta-se em sua cultura material (destacando a produção cerâmica) e nos relatos dos cronistas e de outras fontes etno-históricas. Analisa o quadro espacial dos sítios de ocupação a partir dos seus vestígios e de suas articulações ambientais.

Inicialmente destacamos uma consideração metodológica da autora, pertinente aos critérios de Prous apresentados, para elucidação das terminologias adiante observadas:

Um dos objetivos da tese é demonstrar que o que foi impropriamente denominado Tradição Tupiguarani constitui, na realidade, duas extensões distintas da Tradição Policrômica Amazônica no leste da América do Sul, que pode ser dividida em duas subtradições culturais distintas, a Guarani e a Tupinambá. Estas duas subtradições, partindo de um núcleo comum, teriam se desenvolvido paralelamente a partir de sua separação há pelo menos 2.000 anos. (SCATAMACCHIA, 1990, p. 97, grifo nosso). 
A seguir, a autora cita trecho elucidativo de outro pesquisador (Brochado, 1984), sobre a dinâmica dos percursos e da distribuição dos povos indígenas anteriores ao período dos contatos, que transcrevemos:

"Ainda no início da era cristã, dois ramos de uma cultura tipicamente
amazônica invadiram o leste da América do Sul, seguindo o mesmo
sistema de progressão em forma de pinça observado acima. Pelo
ano 100 , a cultura ou subcultura Guarani já se encontrava bem
estabelecida no sul do Brasil e ao redor do ano 500, a cultura ou
subcultura Tupinambá, uma versão atenuada da cultura Marajoara,
chegou ao nordeste do Brasil. A expansão para leste da cultura
Guarani no sul do Brasil foi lenta e se desenvolveu em vagas
sucessivas, cada vez cobrindo áreas maiores de território. A
expansão da cultura Tupinambá para o sul foi, pelo contrário, rápida
e linear, movendo-se ao longo da estreita faixa costeira. Cerca de
quinhentos anos antes da chegada dos europeus, as duas
mandíbulas das frentes de expansão Guarani e Tupinambá se
chocaram finalmente numa fronteira situada ao sul do curso do
Tietê." (op. cit: 564). (SCATAMACCHIA, 1990, p. 97).

Parte do nosso universo de pesquisa (litoral central e sul de São Paulo) enquadra-se na "fronteira" mencionada acima. Concentra-se, no vale do Ribeira, por esta especificidade, um projeto de pesquisa da autora "[...] questionando a existência, ao longo da costa brasileira, de uma fronteira cultural entre os dois grupos." (SCATAMACCHIA, 1990, p. 101). Algumas questões procedentes foram ventiladas na ocasião de sua formulação:

A própria idéia de zona limite está sendo questionada quanto ao seu significado. Trata-se de uma zona onde os traços culturais sofrem uma mudança brusca ou onde eles aparecem mesclados? Ou, ainda, de uma área que poderia ter se comportado como uma zona neutra entre os Tupinambás e os Tupiniquins, localizados em Angra dos Reis e Bertioga, e os Carijós, de Paranaguá para o sul. Somente a precisa definição do que é Guarani e do que é Tupi, irá permitir a verificação da posição desta área de fronteira a partir de parâmetros referenciais das ocorrências da área ao sul $e$ ao norte. (SCATAMACCHIA, 1990, p. 101).

É, sem dúvida, uma região cuja paisagem social notabiliza-se pela diversidade. O delineamento de suas "fronteiras" é inerente à sua complexidade. Os grupos "Tupinambás e Tupiniquins”, por exemplo, são associados na historiografia (e 
a citação não foge à regra), por pertencerem, decerto, ao mesmo tronco Tupi. Sabemos, todavia, que viviam em clara animosidade, de acordo com várias fontes etno-históricas. Ainda, Tamoio era o designativo dado pelos Tupiniquins de São Vicente aos seus contrários, os Tupinambás do Rio de Janeiro. A etimologia da palavra pode ser reveladora: Tamuya $=$ Avô (BUENO, 1983, p. 449). Neste caso, nossa suposição é de que a temporalidade, implícita no termo, indicaria que os Tupiniquins elegeram a região posteriormente aos Tupinambás, no contexto dinâmico das ocupações dessa frente Atlântica, algumas centenas de anos antes da chegada dos europeus. Essas particularidades (o diferencial temporal e a animosidade, mesmo porque se justificam), respeitando os traços culturais de ascendência comum, no caso, da subtradição Tupinambá, levam-nos a pensar que os habitantes pré-coloniais de Piratininga ainda não têm suas origens elucidadas quando simplesmente incorporados ao ambiente comum da subtradição, com vertente litorânea procedente da região Norte. Sem entrar nos méritos científicos da arqueologia, que não nos compete, não podemos deixar de assinalar que a tribo Tupiniquim, com área de ocupação entre os "campos de Piratininga" e a baixada vicentina, pode representar especificidades da subtradição Tupinambá. Enquanto estas enriquecem a diversidade socioambiental da frente atlântica do Sudeste, comprometem a atribuição de "fronteiras" generalizadas no contexto da região. O historiador cultural alemão Peter Burke (2005) adverte:

A idéia de fronteira cultural é atraente. Pode-se até mesmo dizer que é atraente demais, porque encoraja os usuários a escorregar, sem perceber, dos usos literais aos usos metafóricos da expressão [...]. Aqui também é necessário fazer distinções, por exemplo, entre as visões de fora e as visões de dentro de uma dada cultura. De fora, muitas vezes as fronteiras parecem ser objetivas e até mesmo mapeáveis. [...] De qualquer forma, como as palavras e os números, os mapas podem enganar. Eles parecem implicar uma homogeneidade no interior de uma dada "área de cultura" e uma distinção clara entre os diferentes espaços. (BURKE, 2005, p. 152). 
Adiante expõe conceito que vem ao encontro do questionamento de Scatamacchia, citado no final da página 31:

Outra distinção útil se refere às funções das fronteiras culturais. Historiadores e geógrafos costumam vê-las basicamente como barreiras. Hoje, por outro lado, a ênfase tende a cair nas fronteiras como lugares de encontro ou "zonas de contato". Ambas as concepções têm seus usos. (BURKE, 2005, p. 153).

De qualquer forma, os Tupiniquins tiveram importância diferenciada na gestão do processo colonial paulista, com diversos registros nas fontes etnohistóricas conhecidas.

O "núcleo comum" das subtradições, citado no final da página 39, corresponde à "[...] região do Guaporé, alto Madeira, particularmente entre os rios Guaporé e Jiparaná." (SCATAMACCHIA, 1990, p. 57). Segundo a autora, esta identificação converge de diversas pesquisas. Entre critérios lingüísticos (Dall'igna Rodrigues, 1965) e ecológicos, que consideram a área como refúgio florestal (Migliazza, 1982), situa "[...] o centro de dispersão do tronco tupi nesta região há 5.000 anos, ou seja, mais ou menos 3.000 AC. A família lingüística tupi-guarani teria se desprendido do tronco original desde uns 2.500 anos, ou 500 AC [...]" (SCATAMACCHIA, 1990, p. 58). A motivação principal das movimentações das tribos seria a necessidade de novas terras para a agricultura, que a autora melhor define com o termo horticultura. Observamos que reflete, contudo, a premência do aumento demográfico. Ciclos naturais climáticos podem estar associados ao evento, considerando-se a estreita interação destes povos com o ambiente das florestas tropicais úmidas: "A Amazônia experimentou períodos alternados úmidos e secos, com datação que localiza o episódio mais recente entre 3.000 e 2.000 anos passados, tornando-o, desta forma, contemporâneo à data estimada para a dispersão [...]" (SCATAMACCHIA, 1990, p. 58). Ao considerar que as cerâmicas 
arqueológicas "apresentam-se já desenvolvidas desde os estratos mais antigos", a autora presume que: "[...] houve uma dispersão inicial, devida a circunstâncias já mencionadas, de grupos que partilhavam de uma cultura comum, cujos traços persistiram ao longo dos deslocamentos e se modificaram em função das diferentes orientações [...]" (SCATAMACCHIA, 1990, p. 60).

Desta forma delineiam-se, em duas vertentes, as marchas seculares dos principais povoadores pré-coloniais da frente atlântica brasileira. Seguiram, em direções opostas, as vias naturais que convidavam: os caminhos das águas (Figura 11, p. 46). A região nuclear somava condição geográfica peculiar do relevo continental: articulava cabeceiras das principais bacias hidrográficas sul-americanas. Seus divisores de águas, de baixas altitudes, permeiam planícies inundáveis nos ciclos regulares das estações chuvosas. É um cenário que nos remete à suposição fundamentada no imaginário (nem tanto!) de que o Brasil era ilha, circundado a oeste por rios nascentes de uma imensa lagoa comum! (Figuras 9 e 10, p. 44). Nos dizeres de Scatamacchia,

Não existem obstáculos que demarquem as duas bacias hidrográficas, a Amazônica e a do Prata. A inundação anual das planícies de Mojos e do grande chaco submerge as bacias dos rios Madeira e Paraguai, transformando-as num vasto mar de água doce que possibilita a criação de uma rede de caminhos fluviais que se estende até o estuário do Plata. (SCATAMACCHIA, 1990, p. 54).

Seguramente foi um cenário que contribuiu para a dispersão, levandose em conta as habilidades navegadoras vivenciadas pelas tribos. Esse grande movimento migratório desenhou novos horizontes territoriais aos grupos destacados, de mesmo tronco lingüístico. Assumiram, portanto, disposições espaciais distintas nas duas frentes. Os Tupi, alcançando o delta amazônico, percorre a faixa litorânea em direção ao sul; os Guarani, embora concentrem-se no interior continental, 


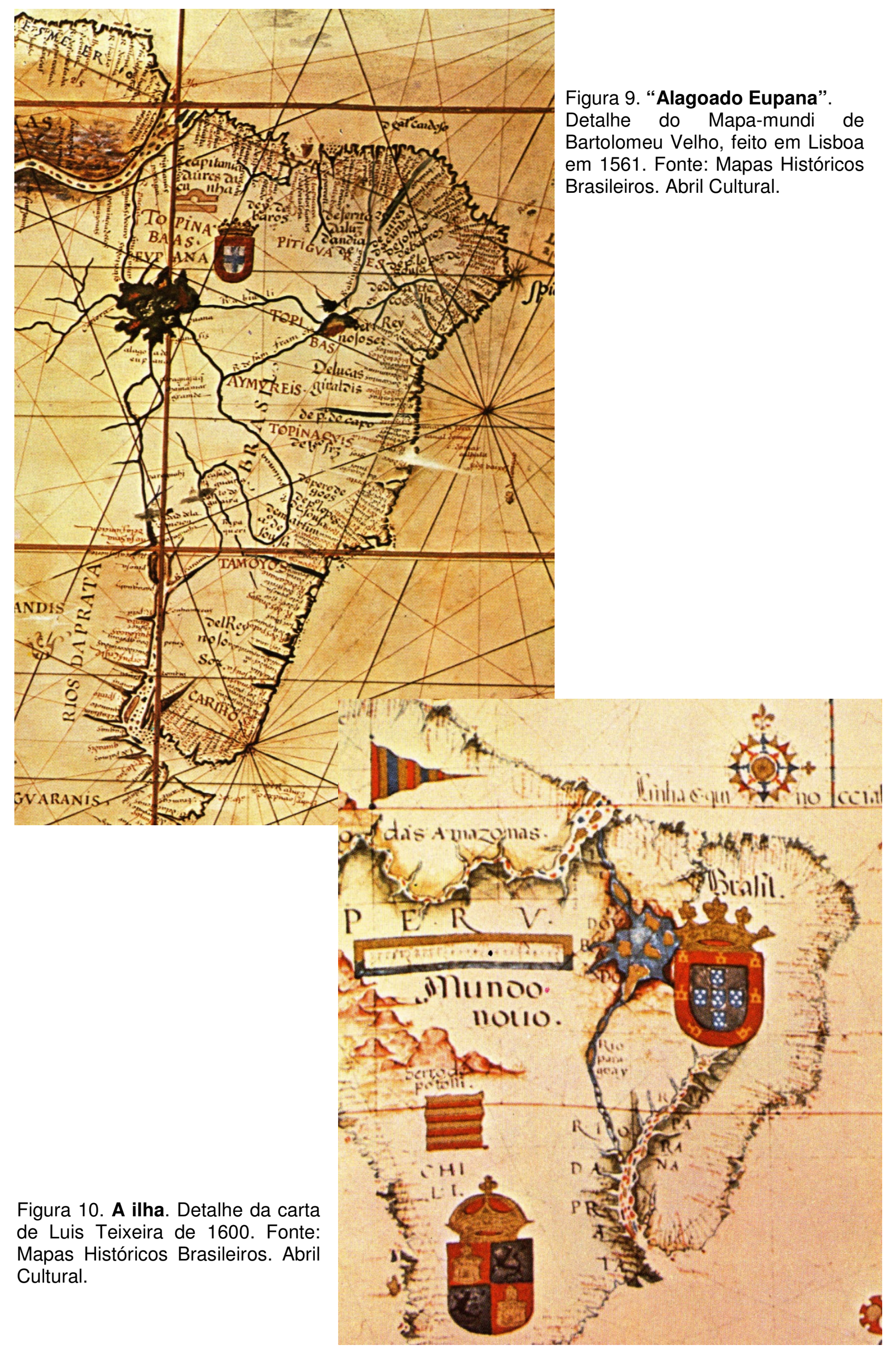


alcançam o delta do Prata e seguem ao Norte até a região de "fronteira" mencionada anteriormente. De acordo com os padrões lingüísticos,

O Tupi era falado do sul da foz do Amazonas ao longo de quase toda a costa Atlântica, do rio Pará e do baixo Tocantins até Cananéia, no sul do Estado de São Paulo, como também, em bolsões no interior, no alto e médio São Francisco, assim como no alto Tietê. O Guarani era falado em um trecho bem menor ao longo do litoral, do sul de Cananéia até o estuário do Prata, ocupando no interior as bacias do Paraná, Paraguai e Uruguai. (SCATAMACCHIA, 1990, p. 62).

A longa trajetória dos grupos tribais ${ }^{2}$, em distribuições territoriais diferenciadas, certamente contribuiu para a incorporação de diversidades culturais:

O longo tempo de afastamento explicaria a ligeira diferenciação lingüística, e a aparente homogeneidade da cultura material estaria ligada à formação já consolidada da cultura matriz e à conseqüente estabilidade de certos traços culturais, característica da estrutura tribal. Se anteriormente predominou a idéia de uma cultura tupiguarani, homogênea, atualmente impõe-se cada vez mais a consciência de algumas diferenças que devem ser levadas em conta para 0 melhor entendimento da estruturação destas tribos. (SCATAMACCHIA, 1990, p. 62).

Para encerrarmos as referências sobre a dispersão Tupi-Guarani, destacamos informação pertinente à contigüidade espacial dos deslocamentos, onde o vetor ambiental orienta as escolhas das zonas povoadas:

$\mathrm{Na}$ realidade todas elas apresentam as condições necessárias ao cultivo dos principais alimentos que compõem a dieta básica destes grupos, pois estas migrações não poderiam implicar mudanças que neutralizassem a eficiência do equipamento adaptativo tribal, pondo em perigo a sobrevivência do grupo. Mesmo tendo, em algumas ocasiões, se estendido fora do seu habitat ideal, esta permanência deve ter sido temporária, pois não puderam ser observadas modificações regionais no sistema tecnológico, que permaneceu 0 mesmo até o contato com o homem branco. (SCATAMACCHIA, 1990, p. 194, grifo nosso).

\footnotetext{
${ }^{2}$ Transcrevemos a nota de pé de página o1 da Tese (SCATAMACCHIA, 1990, p. 53): "Estamos utilizando aqui o termo tribo conforme a seguinte conceituação: 'Entendo o termo 'tribo' como nação no seu sentido mais antigo, um corpo de pessoas de origem e costumes comuns, que possui e controla toda a extensão de seu território' (Sahlins 1970: 7)."
} 


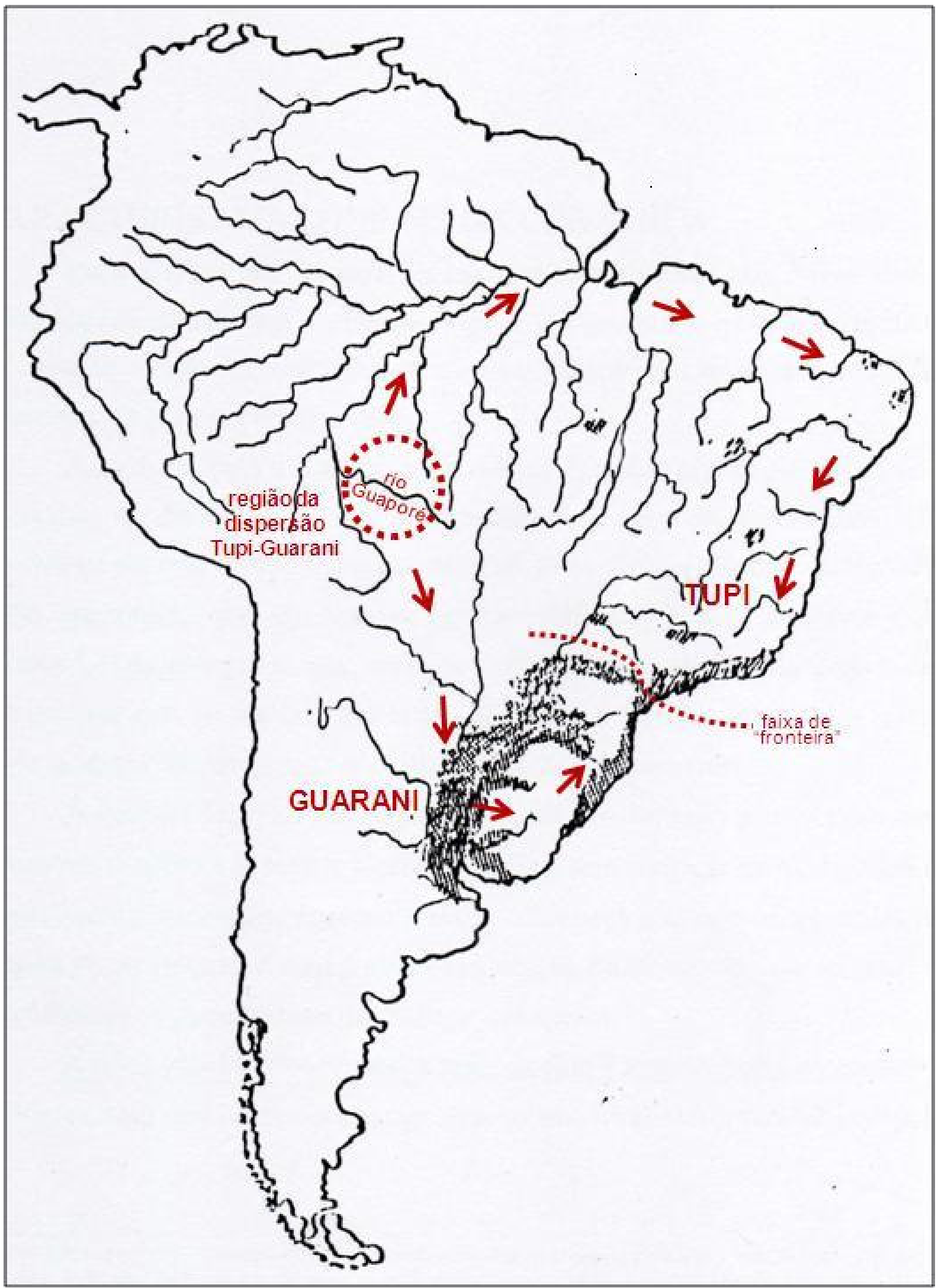

Figura 11. Tupi e Guarani. As mais representativas ocupações pré-coloniais identificadas na frente atlântica. Fonte: SCATAMACCHIA, 1990, p. 83. Mapa de distribuição das evidências arqueológicas da tradição policrômica no leste sul americano. Acrescentados textos e sinalizações do autor. 
Prevalece, na reprodução dos espaços Tupi-Guarani, conforme ressalvado na citação anterior, a eleição dos nichos ecológicos característicos de suas interações ambientais. Alguns fatores convergem no cenário das florestas adjacentes aos rios e estuários marinhos escolhidos: fontes de água potável, fertilidade do solo, abundância de caça, pesca e lenha; seus abrigos portuários articulam navegações e caminhos junto às vias fluviais e marítimas; possuem elevações secas de altiplanos ou morros adequados à salubridade, domínio visual e defesa; há proximidade de argila e pedra para cerâmica e artefatos, além de outras atribuições. O conceito de nicho ecológico, no entanto, não se restringe apenas a atrativos geográficos. Agrega a interação das atividades sociais desempenhadas, no caso, entre os grupos locais (aldeias) e o meio ambiente: o seu modo de vida. Pode ser entendido como a particularização do habitat. Neste caso, a dinâmica envolve a escala territorial da tribo (ver nota 2 - pag. 45$)^{3}$.

O delineamento global aqui apresentado contribui para visualizarmos a distribuição das principais ocupações indígenas da região Sudeste do Brasil. Interessa-nos, especialmente, a caracterização dos espaços da subtradição Tupi comprometidos com o objetivo de nossa pesquisa. Dedicamos as subseções seguintes aos enquadramentos regionais, onde as escalas aproximam as particularidades.

\footnotetext{
3 Habitat e nicho ecológico são conceituados da seguinte forma pelo zoólogo norte-americano Eugene P. Odum: "O termo habitat é profusamente utilizado, não apenas em ecologia mas por toda a parte. Geralmente considera-se que significa o lugar onde vive um organismo." Ou uma "[...] comunidade completa." (ODUM, 2004, p. 376). "O nicho ecológico, por outro lado, é um termo com maior âmbito que inclui, não apenas o espaço físico ocupado por um organismo, mas também o seu papel funcional na comunidade [...]. Consequentemente, o nicho ecológico de um organismo depende não apenas do sítio onde vive mas também daquilo que faz (como transforma energia, se comporta, responde ao seu ambiente físico e biótico e o modifica) [...]. Por analogia, pode dizer-se que o habitat é a 'morada' do organismo e que o nicho é a sua 'profissão, biologicamente falando." (ODUM, 2004, p. 375).
} 


\subsection{Os horizontes marinhos}

Qualquer tentativa, inclusive a nossa, de representar graficamente as áreas de ocupação das sociedades indígenas da frente atlântica do Sudeste brasileiro no distante século XVI, estará suscetível a imprecisões. Nem tanto pela escassez de fontes documentais (etno-históricas), ou de investigações arqueológicas (satisfatória em alguns setores, todavia, aquém dos anseios da ciência), mas pela natureza dinâmica das populações envolvidas especialmente naquele recorte do tempo. Soma-se ao dinamismo intrínseco das culturas indígenas - por suas movimentações seculares e interativas com o meio ambiente - a fragilidade construtiva de suas instalações, a animosidade mantida com grupos vizinhos na consolidação dos seus domínios e a decisiva chegada dos europeus, que culminará com a desestruturação quase total de sua constituição social e, conseqüentemente, com a desfiguração dos seus espaços de ocupação. De qualquer forma, mesmo sem estes desdobramentos, os enquadramentos representativos das ocupações estarão sempre comprometidos: a pluralidade social envolvida e a tenuidade das produções espaciais, suplementares da paisagem ambiental, demandam critérios na adoção de modelos ou metodologias recorrentes em nossa formação ocidental. Nossos "limites" e "territórios", por exemplo, são reflexos de tratativas diametralmente opostas em relação à posse, domínio e propriedade da terra, distantes das interações e vivências que as sociedades pré-coloniais brasileiras exerciam nos seus habitats. É o caso dos limites entre nossos Municípios e Estados, quase sempre balizados em leitos de córregos e rios. São aceitos como demarcatórios de propriedades da terra ou divisões políticas. Todavia são articuladores, vias de drenagem de suas respectivas bacias, cuja homogeneidade ambiental envolve, obviamente, as 
adjacências de ambas as margens. Os nossos referenciais geopolíticos e jurídicos sobre a posse da terra sublimam o significado ambiental das bacias hidrográficas, só recentemente objeto de posturas protetivas enquanto ecossistemas específicos. As nossas sociedades pré-coloniais incorporavam há séculos esta sabedoria, como tantas outras. Os sítios da subtradição Guarani, por exemplo, investigados pela arqueologia, evidenciam escolhas no contexto integral da via fluvial. Decerto não compreenderiam que pescassem ou instalassem aldeias em apenas uma das margens...

Este critério de eleição dos ambientes ocupados, atrelados às bacias hidrográficas, converge com as informações que contribuem com nossa tentativa de delinear a presença dos povos indígenas em nossa área de estudo, conforme Figura 12 da página seguinte. As aldeias da tribo Tupiniquim ocupavam a bacia do alto Tietê, o "planalto de Piratininga", mesopotâmia articulada com seus principais afluentes, atualmente denominados Tamanduateí e Pinheiros. O historiador Benedito Prezia (2004) procura identificar este enquadramento espacial:

Segundo Anchieta, as aldeias tupiniquins do planalto eram em número de 12. Dessas, as crônicas e cartas jesuíticas registraram apenas quatro, todas dentro da referida mesopotâmia: Piratininga (pira $=$ peixe + tininga $=$ seco -0 lugar de peixe seco), a antiga aldeia do líder Tibiriçá e que devia ficar na região onde hoje é o bairro da Luz (...); Geraibatiba, Jeribatiba ou Jurubatuba, aldeia chefiada por Kaiobi, situada provavelmente nas nascentes do rio Jurubatuba-açu; Ybirapuera, na confluência do rio Jurubatuba com 0 rio Guarapiranga, quando formam o rio Pinheiros, talvez um pouco mais à frente, na mesma colina, onde mais tarde surgiu o bairro de Santo Amaro (...); e Ururay (ururâ= lagarto d'água $+y=$ rio. Rio do lagarto d'água), provável aldeia do "principal" Piquerobi, não longe do rio Tietê, onde mais tarde foi fundada a missão de São Miguel (...). Talvez Barueri e Carapicuíba, à beira do Tietê, o bairro de Pinheiros, às margens do rio do mesmo nome, e Mboi'y, hoje Embu das Artes, perto do ribeirão da Ressaca - todos aldeamentos missionários -, tivessem sido antigas aldeias indígenas. (PREZIA, 2004, p. 65). 


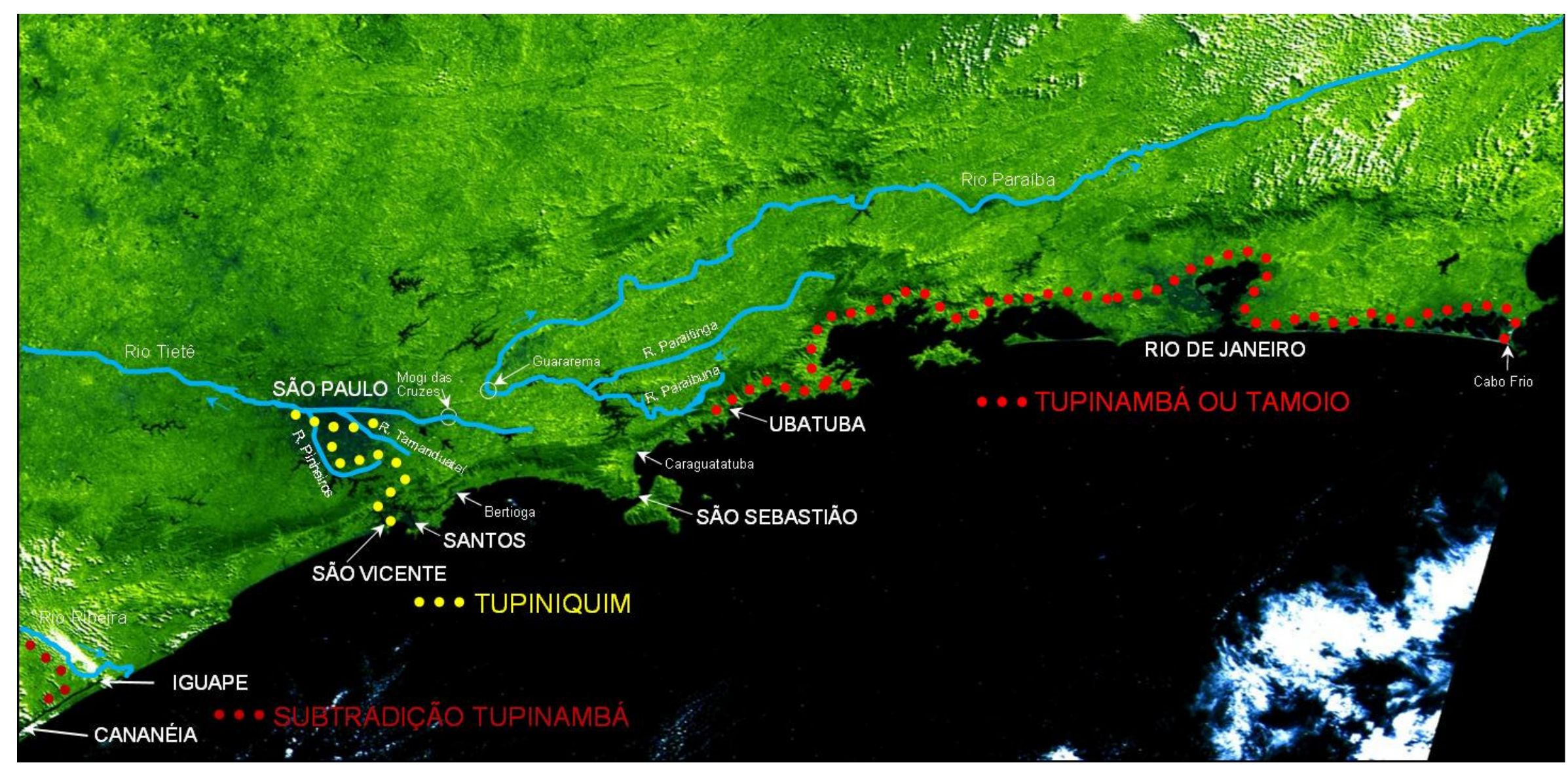

Figura 12. Nossa frente atlântica. Um quadro singelo das ocupações Tupi que assistiram a chegada dos europeus no século XVI, marcando para sempre a paisagem e os seus destinos. Fonte: INPE Sat. Cbers 2000. Acrescentados textos e sinalizações do autor. 
Notamos dificuldades, até nas mais recentes pesquisas, na localização de assentamentos indígenas. Observamos anteriormente algumas razões dessas imprecisões. Além da dinâmica natural das sociedades pré-coloniais, uma fonte primária tornou-se armadilha para a historiografia na identificação dos ocupantes do planalto paulistano, dificultando mais ainda seu enquadramento espacial. O cronista do século XVI, Gabriel Soares de Sousa (1987), no Capítulo LXIII da Primeira Parte, Que trata de quem são os guaianases e de seus costumes, totalmente transcrito a seguir, relata:

Já fica dito como os tamoios são fronteiros de outro gentio, que se chamam os guaianases, os quais têm sua demarcação ao longo da costa por Angra dos Reis, e daí até o rio de Cananéia, onde ficam vizinhando com outra casta de gentios, que se chama os carijós. Estes guaianases têm continuamente guerra com os tamoios, de uma banda, e com os carijós da outra, e matam-se uns aos outros cruelmente; não são os guaianases maliciosos, nem refalsados, antes simples e bem acondicionados, e facílimos de crer em qualquer coisa. É gente de pouco trabalho, muito molar, não usam entre si lavoura, vivem de caça que matam e peixe que tomam nos rios, e das frutas silvestres que o mato dá; são grandes flecheiros e inimigos de carne humana. Não matam aos que cativam, mas aceitam-nos por seus escravos; se encontram com gente branca, não fazem nenhum dano, antes boa companhia, e quem acerta de ter um escravo guaianá não espera dele nenhum serviço, porque é gente folgazã de natureza e não sabe trabalhar. Não costuma este gentio fazer guerra a seus contrários, fora dos seus limites, nem os vão buscar nas suas vivendas, porque não sabem pelejar entre 0 mato, senão no campo aonde vivem, e se defendem com seus arcos e flechas dos tamoios, quando the vêm fazer guerra, com quem pelejam no campo mui valentemente e às flechadas, as quais sabem empregar tão bem como os seus contrários. Não vive este gentio em aldeias com casas arrumadas, como os tamoios seus vizinhos, mas em covas pelo campo, debaixo do chão, onde têm fogo de noite e de dia e fazem suas camas de rama e peles de alimárias que matam. A linguagem deste gentio é diferente da de seus vizinhos, mas entendem-se com os carijós; são na cor e proporção do corpo como ao tamoios, e têm muitas gentilidades, como o mais gentio da costa. (SOUSA, 1987, p. 115).

Quando o cronista mais prestigiado da historiografia varre do mapa a etnia Tupiniquim, atribui somente aos Guaianá, do tronco lingüístico Jê, um enquadramento regional na verdade partilhado, mas onde a tribo de matriz Tupi 
certamente predominava, conforme verificado com o avanço das pesquisas. Certas generalizações parecem reveladoras de informações contraditórias por parte do autor. Seu Tratado Descritivo do Brasil, escrito na Espanha entre 1585 e 1587 (período de unificação das coroas), enquanto aguardava recursos e autorização real para exploração de riquezas no interior do Brasil, pode conter imprecisões. Pelo fôlego "enciclopédico" do texto, provavelmente baseou-se em relatos produzidos para este fim, tal como a minuciosa descrição e registro de latitudes de todos os estuários da costa brasileira adequados a condições portuárias. Alguns aspectos da diversidade social talvez não tenham sido devidamente alinhados, considerando-se ainda, por seu status de senhor de engenho, que as informações do Tratado são voltadas para o desenvolvimento colonialista. Procede a informação de que os Guaianá não habitavam aldeias "com casas arrumadas", característica dos grupos caçadores-coletores, ou que habitavam casas semi-enterradas, identificadas pela arqueologia principalmente nas regiões altas e frias das araucárias paranaenses. Ao contrário, o grupo Tupiniquim de Piratininga habitava aldeias "como os tamoios seus vizinhos", sem que nenhum outro registro etno-histórico mencione nesta região a adoção de casas semi-enterradas. O fato é que perdurou na historiografia a designação "guaianases" para os principais habitantes pré-coloniais do planalto paulistano. Em artigo citado, o antropólogo Egon Schaden (1954), ao discorrer sobre a diversidade dos povos indígenas do Estado de São Paulo, preocupa-se em corrigir o rumo da identificação: "Mas o exame e o confronto da documentação leva a admitir com bastante segurança que o nome de Goianá ou "Guaianazes" se aplicava aos próprios Tupinikín.” (SCHADEN, 1954, p. 395). Outro cronista do século XVI, no entanto, registra com clareza, em publicação de 1557, a designação dos habitantes da região. Hans Staden (1974), ao descrever São Vicente, observa: 
Os portugueses que aí moram são amigos de uma tribu de selvagens brasileiros, os tupiniquins, cuja região se estende em oitenta milhas para o interior da terra e quarenta ao longo da costa. Ao norte e ao sul desta região habitam inimigos desta tribu. Os inimigos ao sul são os carijós, os do norte chamam-se tupinambás. (STADEN, 1974, p. 72).

Estas considerações são importantes para que o enquadramento das ocupações aproxime-se ao máximo do real. Ainda na área de presença Tupiniquim, destacamos registro significativo da pesquisadora Maria Cristina Scatamacchia (1990). Ao elencar diversos sítios arqueológicos da subtradição Tupinambá, sem fazer distinção com o designativo Tupiniquim, a autora escreve:

Na zona urbana da capital paulista temos a menção da existência de várias aldeias no século XVI (Machado de Oliveira, 1848; Drummond, 1973), assim como evidências desta cerâmica em alguns bairros paulistanos, como Morumbi e Brás (Pereira Jr, 1964, 1967). (SCATAMACCHIA, 1990, p. 204).

Outra região, objeto de investigações de Scatamacchia, contribui para o alinhamento de nossa pesquisa: o baixo curso do rio Ribeira, nas proximidades da cidade de Iguape. Segundo a autora, nesta área, “(...) os sítios localizam-se em pequenas elevações na margem do Ribeira e junto aos seus principais afluentes da margem direita, Jacupiranga, Pariqueraçu e Momuna (...)." A seguir, retoma a descrição:

Ao longo do mar Pequeno, entre Iguape e Icapara, em uma faixa de $12 \mathrm{~km}$ em linha reta, pudemos evidenciar três sítios, sendo que para esta região mais à beira mar os sítios são mais próximos do que subindo o Ribeira. Resumindo, os sítios evidenciados até agora são sítios-habitações (...). Apresentam grande quantidade de cerâmica e nos dois sítios mais próximos ao mar Pequeno, que foram escavados, foram evidenciados material de contacto, como contas de vidro e pedaços de ferro. (SCATAMACCHIA, 1990, p. 204).

Estes referenciais nortearam a representação sucinta da ocupação précolonial do universo Tupiniquim, expresso na Figura 12 - p. 50, com a necessária particularização do extremo sul desta frente atlântica, contexto do lagamar de Cananéia e Iguape. Conforme exposto, os assentamentos desta localidade eram 
"sítios-habitações", da mesma forma que ocorriam nos "campos de Piratininga". Não há informações se contextualizavam a mesma tribo de São Paulo, ou quais seriam as relações sociais e vivenciais entre estes grupos locais e os do planalto, ambos de tronco Tupi. Alguns diferenciais merecem anotação. Sabemos que o lagamar vicentino era ocupado sazonalmente, como veremos, pelos Tupiniquins do planalto. Não há registro da existência de aldeias nesse setor litorâneo, intimamente vinculado a Piratininga. Certamente os indígenas utilizavam os locais mais aprazíveis da baixada como acampamentos, voltados à pesca da tainha e coleta de crustáceos, especialmente nos meses do inverno. Neste recorte geográfico, portanto, a mesopotâmia do alto Tietê e a marinha complementavam-se, cenários do mesmo habitat. Ao sul, a paisagem diferenciada não seria necessariamente complementar. O relativo isolamento regional (contido pelos contrafortes da serra do Mar), a amplitude da planície costeira, bacia do rio Ribeira, e a riqueza do lagamar marinho, permitiriam que estes grupos locais identificados encontrassem nessa diversidade ambiental o delineamento do seu próprio habitat. Portanto, como ainda não temos registros precisos de sua caracterização, assinalamos a localidade enquanto ocupação de Subtradição Tupinambá, conforme pesquisa de Scatamacchia.

A representação da área de ocupação Tupinambá, ou Tamoio, na escala de aproximação da Figura 12, é menos complexa. Esta sociedade indígena, objeto de maior atenção dos cronistas e da historiografia, ocupava predominantemente a faixa litorânea. Os sítios arqueológicos evidenciam que a ocupação limitava-se ao norte na localidade de Cabo Frio e ao sul na localidade de Ubatuba, cidade litorânea paulista, atestando as fontes de diversos autores que enquadravam o mesmo setor com poucas divergências. Além do predomínio litorâneo, com as principais aldeias 
gravitando em torno da baía da Guanabara, os Tamoios ocupavam trecho continental. Hans Staden (1974) observa:

Os tupinambás habitam defronte da citada grande serra, bem junto do mar; mas também além da montanha se estende o seu território por cerca de sessenta milhas. No rio Paraíba, que nasce nesta serra e corre paralelo à costa, desembocando então no mar, têm eles também terra, que habitam, beirando uma região de vinte e oito milhas de comprimento. (STADEN, 174, p. 154).

Não há localização precisa desta ocupação, ao que parece particularizada no contexto do habitat tribal. Provavelmente ocorria no curso médio do rio Paraíba, em diretriz perpendicular às maiores concentrações litorâneas do Rio de Janeiro ou de Angra dos Reis, onde o cronista esteve prisioneiro. Scatamacchia menciona pesquisas que podem ser pertinentes:

No curso médio do rio Paraíba, foram estabelecidas as fases Itaocara (Dias, 1969, 1973, 1980) e a Ipuca (Dias, 1973, 1980). A primeira localiza-se ao longo do rio Paraíba, em encostas de pequenas elevações, parecendo que a ocupação se estende para o sul do curso do rio (Dias, 1980). A fase Ipuca possui sítios pequenos em torno de $100 \mathrm{~m}^{2}$ e refugo de $40 \mathrm{~cm}$. (SCATAMACCHIA, 1990, p. 210).

A representação do universo

Tupinambá da Figura 12 baseia-se em ilustração das pesquisadoras Salete Neme e Maria da Conceição Beltrão (1993), reproduzida neste trabalho como Figura 13. Complementamos a

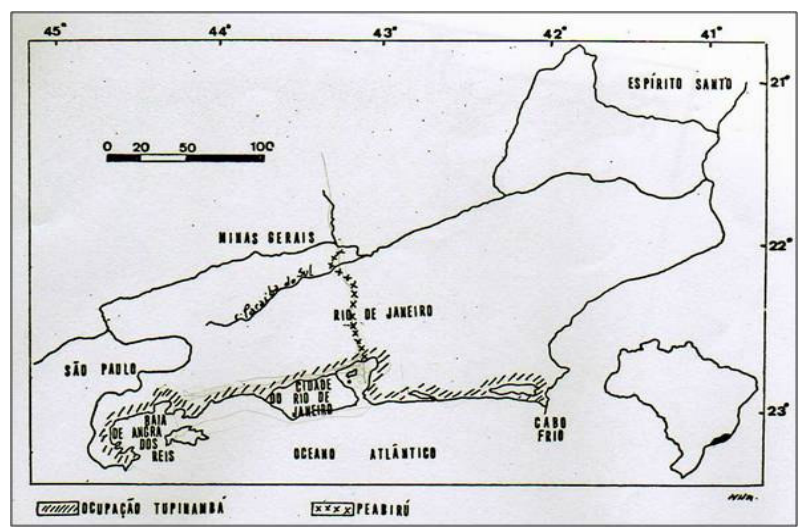
informação assinalada estendendo a Figura 13. Tupinambás no Rio de Jane faixa litorânea na direção sul até a localidade de Ubatuba. Há registros precisos da presença de grupos locais dessa tribo no local. Um deles é a "Carta ao Geral Diogo Laines, de São Vicente, 8 de janeiro de 1561", escrita por José de Anchieta (RIBEIRO, 1992, p. 255). Outro são as evidências arqueológicas do "Sítio Itaguá", 
obtidas em pesquisa realizada por volta de 1984 e relatadas por Dorath Pinto Uchôa e Scatamacchia (SCATAMACCHIA, M. C. M. e UCHÔA, D. P., 1993). Desta forma, as representações da Figura 12 procuram traduzir o enquadramento regional das principais sociedades indígenas desta frente atlântica no período imediatamente anterior e subseqüente ao contato euro-indígena. É o recorte histórico da gênese dos núcleos urbanos litorâneos de nosso interesse, particularizados adiante. A seguir, ainda no contexto regional, algumas aproximações entre os universos Tupinambá e Tupiniquim são necessárias. As dinâmicas sociais e ambientais, próprias ou comuns a cada grupo, e inter-tribais, serão balizadoras da interação cultural desencadeada a partir da chegada dos europeus, com resposta na instalação, produção e articulação regional dos espaços urbanos.

\subsection{0 litoral Tupinambá}

O sociólogo Florestan Fernandes (1963) dedicou diversos estudos sobre esta sociedade indígena na obra Organização Social dos Tupinambá. Destacamos a análise morfológica sobre os grupos locais. Sistematizada em critérios metodológicos, contribui para a compreensão da estrutura social e espacial da tribo. No início do Capítulo II, escreve:

Esta parte do trabalho é dedicada ao estudo morfológico dos grupos locais. O grupo local, descrito pelos antigos cronistas sob o nome de "aldeia", constitui uma unidade social de grande importância analítica, quanto aos Tupinambá. É o grupo social que se coloca entre a menor unidade territorial - a "maloca" - e a unidade territorial inclusiva, a tribo. Os liames primários que unem reciprocamente os indivíduos nesse grupo são vicinais, envolvendo proximidade no espaço e coexistência no tempo. Do ponto de vista estrutural, o grupo local resulta da vida em comum permanente de diversos grupos familiares e constitui o elemento integrativo fundamental de que se compõe a tribo Tupinambá. Para designá-lo poderia também usar o termo tupi-guarani Taba. Contudo, os cronistas não são 
uniformes no emprego de um designativo da língua nativa, em suas descrições. Por isso, preferi utilizar-me de um vocabulário já consagrado pelo uso etnológico. (FERNANDES, 1963, p. 59, grifo nosso).

Baseado no relato de diversos cronistas, o autor apresenta dados estatísticos que configuram a distribuição dos grupos locais em suas áreas de ocupação, de onde destacamos que "Na região de Angra dos Reis, Hans Staden indica expressamente 5 grupos locais Tupinambá, embora o texto sugira maior número. São os grupos locais: Ariró, Mambucaba, Taquaraçu-tiba, Ubatuba e Ticoaripe." (FERNANDES, 1963, p. 60). No quadro reproduzido abaixo, notamos, em relação à nossa frente atlântica, a predominância dos grupos locais nas adjacências da Baía da Guanabara:

\begin{tabular}{|c|c|}
\hline \multicolumn{2}{|c|}{$\begin{array}{c}\text { Quabro I } \\
\text { Grupos locais Tupinambá do Rio de Janeiro e Maranhão }\end{array}$} \\
\hline REGIÃO & $\begin{array}{l}\text { GRUPOS } \\
\text { LOGAIS }\end{array}$ \\
\hline 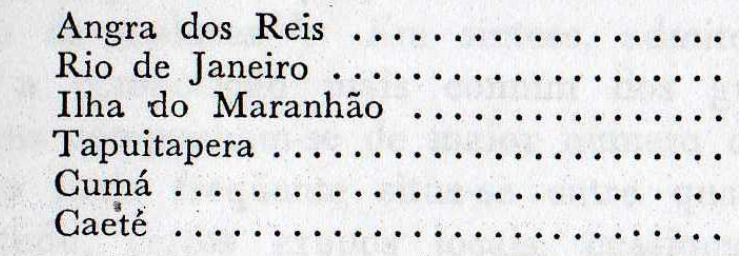 & $\begin{array}{r}5 \\
22 \\
27 \\
10 \\
11 \\
20\end{array}$ \\
\hline TOTAL $\ldots \ldots \ldots+\ldots, \ldots$ & 95 \\
\hline
\end{tabular}

Fernandes reflete sobre a possibilidade de estabelecer valor estatístico quanto às dimensões territoriais de abrangência dos grupos locais. Dados confiáveis na ilha do Maranhão permitem aceitar "[...] uma média de 45 quilômetros quadrados para cada grupo local." (FERNANDES, 1963, p. 63). Mas entende que são condições específicas, impossíveis de se transpor para outros quadros ambientais. Quanto à região sudeste, observa que foram vagas as menções dos cronistas: "Thevet, referindo-se à aldeia do cacique Cunhambebe, escrevia: 'sua aldeia com os 
territórios correspondentes, é vasta..." A seguir o sociólogo conclui: "Deve-se, portanto, abandonar por impraticável a possibilidade de estabelecer conjeturas seguras ou prováveis sobre o número de grupos locais Tupinambá, existentes no século XVI e XVII." (FERNANDES, 1963, p. 64).

Sobre a organização dos grupos locais, Fernandes relata que compunham-se de um número variável de subunidades vicinais - "malocas" - que variavam de quatro a oito unidades. Porém, "A maioria das informações dos cronistas dos séculos XVI e XVII, principalmente dos jesuítas, permite estabelecer, para o grupo lingüístico Tupí, um número médio de quatro malocas por 'aldeia' ou grupo local." (FERNANDES, 1963, p. 64). O autor ainda observa sobre o uso do espaço:

As malocas eram dispostas no solo de modo a deixar uma área quadrangular bastante ampla, o terreiro. Abbeville define-o como 'uma praça grande e bonita'. No terreiro decorria uma parte importante da vida social. Nêle realizavam os sacrifícios rituais, os bailes e festas, e as reuniões do conselho dos chefes. As malocas eram circundadas por um sistema de fortificações. (FERNANDES, 1963, p. 65).

E prossegue com significativa análise demográfica:

As malocas podem ser encaradas, do ponto de vista morfológico, como forma de solução de tensões demográficas desenvolvidas no grupo local. Com isto, quero dizer que os aumentos nos índices de crescimento vegetativo dos moradores de uma maloca provavelmente repercutiam na emergência de novas unidades territoriais semelhantes, isto é, de novas malocas. Asseguravam, assim, tanto o equilíbrio interno das malocas, quanto o dos grupos locais. Para um índio construir uma maloca, precisava atrair 'cerca de quarenta homens e mulheres', reunindo-os em casa comum nova, por eles construída. O Tupinambá que conseguia fazer isso tornavase o chefe da unidade social, ou como escrevem os cronistas, seu "morubixaba" ou "principal". Exercia certa autoridade sobre os membros da maloca, que eram "usualmente seus amigos e parentes." (FERNANDES, 1963, p.66).

Pensamos que estas "tensões demográficas", mencionadas por Fernandes, seriam motivadoras, entre outras razões, das mudanças cíclicas de localidade das aldeias, especialmente se o sítio ocupado fosse restrito ao espaço de novas 
habitações comunais. Ainda, justificariam também a constituição de novos grupos locais, pois, como veremos adiante, eram de pequenas proporções.

A seguir, o autor apresenta quadro dimensional das malocas e do número de moradores, baseado nas fontes etno-históricas:

\begin{tabular}{|c|c|c|c|c|}
\hline \multirow{3}{*}{ Autor } & \multicolumn{3}{|c|}{ Quadro II } & Dimensões da Maloca Tupinambá. \\
\hline & \multicolumn{2}{|c|}{ Largura } & \multicolumn{2}{|c|}{ Comprimento } \\
\hline & U. A. * & Metros & $U \cdot A .^{*}$ & Metros \\
\hline Staden & 14 pès & 4,62 & 150 pés & 49,50 \\
\hline Thevet & 20 pés & 6,6 & 200 a 300 pés & 66 a 99 \\
\hline Léry. & - & & $60,80,120$ pés & $20,27,40$ \\
\hline Cardim & 50 palmos & 11,0 & $\begin{array}{l}200,300,400 \\
\text { palmos }\end{array}$ & $44,66,88$ \\
\hline $\begin{array}{l}\text { Abbeville } \\
\text { Knivet }\end{array}$ & 26 a 30 pés & $\begin{array}{c}8,59 \text { a } 9,90 \\
-\end{array}$ & $\begin{array}{l}200 \text { a } 500 \text { pés } \\
220 \text { varas }\end{array}$ & $\begin{array}{l}66 \text { a } 165 \\
242\end{array}$ \\
\hline
\end{tabular}

Comenta que Métraux fala em malocas de até 100 metros de comprimento por 10 a 16 de largura, mas adverte: "As dimensões da maloca Tupinambá não são, entretanto, exageradas." (FERNANDES, 1963, p. 67).

\begin{tabular}{|c|c|c|}
\hline \multicolumn{3}{|c|}{$\begin{array}{l}\text { QUadro III } \\
\text { Moradores das Malocas. }\end{array}$} \\
\hline FONTES & $\begin{array}{c}\text { LARES } \\
\text { POLIGINOS }\end{array}$ & INDIVÍDUOS \\
\hline $\begin{array}{l}\text { Pigafetta } \ldots \ldots \ldots \ldots \ldots \\
\text { Staden } \ldots \ldots \ldots \ldots \ldots \ldots \\
\text { Léry } \ldots \ldots \ldots \ldots \ldots \ldots \\
\text { Cardim } \ldots \ldots \ldots \ldots \ldots \\
\text { Salvador } \ldots \ldots \ldots \ldots \ldots \ldots \\
\text { Vasconcellos } \ldots \ldots \ldots \ldots \\
\text { Nóbrega } \ldots \ldots \ldots \ldots \ldots\end{array}$ & 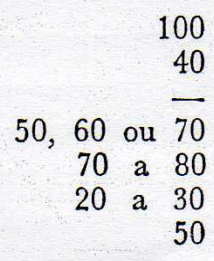 & $\begin{array}{c}-\overline{-} \\
500 \text { a } 600 \\
100,200 \text { e mais } \\
- \\
-\end{array}$ \\
\hline
\end{tabular}

Comparando os dados de diversos cronistas, o autor afirma: "Em conclusão, parece-me que os melhores limites - mínimo e máximo - do número de moradores 
por maloca, são os compreendidos nos totais fornecidos por Fernão Cardim e Jean

de Léry." (FERNANDES, 1963, p. 69).

Ao tratar dos laços de união entre os moradores das malocas, afirma que eram mais íntimos e fortes do que entre os moradores de malocas diferentes. E discorre sobre as interações socioambientais que, por sua abrangência, transcrevemos integralmente:

Quando não havia parentesco, os laços congeniais constituíam o principal motivo de agregação. Por isso, pode-se definir a maloca como autêntica "comunidade efetiva de vida". Dificilmente se poderia conceber uma situação em que a coexistência espacial e temporal se reflita de modo tão profundo nos contatos sociais de seres humanos. Para entender-se completamente esta afirmação é preciso apreciar devidamente os traços característicos da maloca e o modo pelo qual afetavam a vida social dos seus moradores. (...) Dentro da maloca não existia separação nenhuma entre os diversos lares políginos. Cada família, no caso de o homem ter uma só esposa, ou cada esposa da família polígina, dispunha de uma área exclusiva da maloca, chamada lanço ou rancho pelos informantes. Nela viviam: o marido, a mulher, os filhos do casal e os agregados, se existissem (parentes ou cativos de guerra). Nos casos de família polígina, o chefe de família ficava alternadamente no lar da mulher "com que lidava e the dava de comer". Essa área, desfrutada com exclusividade por um grupo de parentes e afins, variava entre quatro e sete metros de comprimento. Nela ficavam: as redes no centro, presas a fortes pilares, e os demais objetos da família, e nela acendiam seus fogos. O mais importante é que a maloca apresentava-se dessa forma, completamente repleta, mas o espaço era distribuído de forma racional e eqüitativo. Ao todo, a maloca dividia-se em cinqüenta, sessenta ou setenta ranchos, distribuídos em pares, um defronte do outro, pelos dois lados da habitação. De tal modo, porém, que não existiam repartições internas. Os próprios tirantes demarcavam os limites de cada área. Por isso, escrevia Abbeville, que ao entrar-se em uma maloca via-se tudo, "de ponta a ponta". Com exceção das tendas de campanha, a maloca constituía o único abrigo comum, de ordem cultural, que podia proteger 0 homem contra as variações de temperatura e contra a chuva. Neste sentido, sua eficiência foi anotada por quase todos os cronistas e, particularmente elogiada até com certo entusiasmo por Claude d'Abbeville. O ingresso era facilitado pela combinação de duas portas laterais, localizadas nas extremidades, e uma porta intermediária, situada no centro da maloca. Apesar das referências muito desfavoráveis de alguns autores, como o Pe. Antônio Blásquez, deve-se admitir que as malocas representavam uma tentativa bem sucedida de adaptação ao meio. A prova mais convincente disso está no fato de ter assegurado aos Tupinambá um tipo de abrigo considerado eficiente por eles mesmos. Quando o contato com os brancos atingiu a fase destribalizadora, esse foi um dos valores a que mais se apegaram. Os próprios brancos se utilizaram das 
malocas, coabitando nelas no início da colonização com os nativos. E não tiveram dúvidas em perpetuá-las em "aldeias" administradas. Em virtude do teste aplicado à seleção das áreas em que construíam suas malocas, os Tupinambá conseguiam assegurar um mínimo indispensável de garantias e de conforto. Esse mínimo foi avaliado etnocêntricamente pelos brancos, e menosprezado. Entretanto, por mais rudimentar que tais garantias e conforto nos pareçam, é evidente o fato de que as técnicas postas em prática asseguravam certos tipos de controle do meio ambiente, reputados vitais pelos Tupinambá. Assim, a localização espacial do grupo local na porção de territórios dominados por seus membros assegurava especificamente: provimento fácil e contínuo de água potável e de certas qualidades de lenha, destinadas ao fornecimento de calor e a outros usos. Além disso, colocava os indivíduos em situação vantajosa, com relação às atividades econômicas. A área espacial ocupada pelo grupo local mantinha uma relação estratégica com o resto do território sujeito ao seu controle. A localização daquela área dentro da totalidade dos territórios dominados pelo grupo devia permitir, principalmente, acesso fácil e seguro às fontes de subsistência. De acordo com as fontes citadas, o grupo visava assegurar, especificamente, a proximidade de zonas piscosas (rios ou da costa marítima) e de terras agrícolas férteis. A abundância de caças e de aves, que forneciam certos tipos de penas, nos bosques circundantes, também precisava ser garantida. Por isso a localização do grupo local constituía um problema vital para os Tupinambá. E era resolvido por meio de reunião em conselho dos velhos e chefes de maloca. O mais importante, quanto à questão que nos preocupa aqui, é que tal localização no espaço atribuía à maloca um papel de relevo na regulamentação das atividades sociais, como se pode concluir dos dados acima expostos. Em primeiro lugar, localizando os componentes da maloca e suas atividades dentro da área ocupada especificamente pelo grupo local ou dentro do espaço ocupado por um conjunto de malocas. Em segundo lugar, localizando as atividades de seus componentes dentro de todo o conjunto de territórios dominados pelo grupo local. Os dois itens evidenciam a existência de conexões gerais entre a vida na maloca e o sistema total de adaptações e controles dos Tupinambá no mundo natural circundante. Essas conexões desenvolviam laços especiais entre os indivíduos, colocando-os em relações determinadas na luta em comum pelos meios de subsistência. (FERNANDES, 1963, p. 69, grifo nosso).

Geralmente só se abandonava a maloca por casamento, quando o homem passava a morar com a família da noiva ou quando alguém conseguia reunir novo grupo em torno de si enquanto líder; isso lhe dava importância pelos guerreiros a ele subordinados. As malocas abrigavam, desta forma, grupos guerreiros fortemente solidários. Esta comunhão estendia-se às atividades econômicas e afetivas. Pero de 
Magalhães de Gândavo (2004), cronista considerado o primeiro historiador do Brasil, observou:

Em cada casa dessas vivem todos muito conformes, sem haver nunca entre eles nenhuma diferença; antes são tão amigos uns dos outros que o que é de um é de todos, e sempre de qualquer coisa que um coma, por pequena que seja, todos os circunstantes hão de participar dela. (GÂNDAVO, 2004, p. 139).

Houve unanimidade entre os cronistas no registro da harmonia vivencial entre os indivíduos do mesmo grupo tribal. Não podemos deixar de registrar também as palavras do padre jesuíta Fernão Cardim (1978). O contraditório dos seus referenciais, todavia, não maculam a "conformidade":

Cada casa destas tem dois ou três buracos sem portas nem fecho: dentro nellas vivem logo cento ou duzentas pessoas, cada casal em seu rancho, sem repartimento nenhum, e moram duma parte e outra, ficando grande largura pelo meio, e todos ficam como em communidade, e entrando na casa se vê quanto nella está, por que estão todos á vista uns dos outros, sem repartimento nem divisão. $\mathrm{E}$ como a gente é muita, costumam ter fogo de dia e noite, verão e inverno, porque o fogo é sua roupa, e elles são mui coitados sem fogo. Parece a casa um inferno ou labyrinto, uns cantam, outros choram, outros comem, outros fazem farinhas e vinhos, etc. e toda casa arde em fogos; porem é tanta a conformidade entre elles, que em todo o anno não há peleja, e com não terem nada fechado não há furtos; se fora outra qualquer nação, não poderiam viver da maneira que vivem sem muitos queixumes, desgostos, e ainda mortes, o que se não acha entre elles. (CARDIM, 1978, p. 185).

Prosseguindo nos estudos, Fernandes observa:

Mas não seria legítimo encarar a maloca Tupinambá como uma unidade social auto-suficiente. Ela era a unidade de um grupo vicinal, a menor forma social Tupinambá de organização das relações sociais no espaco e no tempo. Por isso existia como grupo social articulado a uma constelação de grupos sociais e como parte de um sistema mais amplo de ajustamentos e controles sociais. (FERNANDES, 1963, p. 74, grifo nosso).

Adiante o autor reitera: "A maloca como unidade social, não poderia subsistir sem o funcionamento do sistema total de adaptações e de ajustamentos recíprocos, desenvolvidos no grupo local". Este, por sua vez, "[...] constituía, eventualmente, uma unidade social ofensiva e defensiva." (FERNANDES, 1963, p. 76). As 
expedições guerreiras mobilizavam vários grupos locais em solidariedade; mesmo quando só um se comprometia em combates, os grupos locais vizinhos aplaudiam e comemoravam seus feitos. Não cultivavam a inveja ou o rancor, ao contrário, estimulavam-se. Quanto à extensão territorial entre os grupos locais, encerrando os estudos sobre esta fonte, citamos:

Staden dá exemplos de contatos entre membros de grupos locais situados a quatro e a seis milhas de distância. Thevet fala em relações entre grupos distanciados de dez a doze léguas, e de trinta a quarenta léguas. Gabriel Soares apresenta também estes dois últimos totais, enquanto o Pe. Cardim nos indica os dois primeiros. [...] A julgar pelas sugestões incidentais das fontes, é provável que os grupos locais considerados vizinhos ficavam dentro de uma área espacial compreendida entre nove e oitenta quilômetros. Mesmo entre estes, porém, os contatos eram difíceis, e por isso intermitentes e muito espaçados. (FERNANDES, 1963, p. 79).

Outra fonte angular para o encaminhamento de nossa pesquisa contribuiu muito na caracterização das ocupações pregressas ao colonialismo e no posterior seqüenciamento dos espaços urbanos. Alinha os conceitos expostos acima com o pragmatismo da ciência arqueológica. Salete Neme e Maria da Conceição Beltrão (1993), já citadas na contribuição da Figura 13, no ensaio Tupinambá, franceses e portugueses no Rio de Janeiro durante o século XVI, afirmam sobre $A$ estratégia de ocupação:

Os Tupi-Guarani empregaram, para ocupação do território brasileiro uma estratégia alicerçada em um tripé, composto, por sua vez, de aldeias, acampamentos e peabirus. A hipótese, de autoria de Beltrão, acrescenta ainda que para melhor domínio das áreas, além da aldeia central, estabelecida junto à orla marítima ou nos morros em forma de meia-laranja com visão de $360^{\circ}$ da linha do horizonte, refletindo uma preocupação defensiva, esse grupo usava meios ofensivos. Esses meios eram os próprios acampamentos, com funções distintas (caça, pesca, coleta, guerra, viagens), mas que serviriam primeiramente de marcas territoriais. Ligando aldeias e acampamentos, situados às vezes a dois ou três dias de viagem, distribuíam-se os caminhos conhecidos como "peabirus". (NEME; BELTRÃO, 1993, p. 135, grifo nosso).

Este enquadramento espacial, por sua objetividade, elucida a presença dos Tupinambás no litoral norte do atual Estado de São Paulo no período dos contatos 
euro-indígenas. Veremos que a localidade de São Sebastião era nitidamente um acampamento voltado às estratégias guerreiras que esta tribo mantinha com os Tupiniquins. Ubatuba, da mesma forma, inseria-se no mesmo contexto. Ao que parece, de acampamento passará a sede de aldeias, numa transição que pode ter sido testemunhada por fontes etno-históricas e investigação arqueológica, conforme veremos na tratativa específica da gênese deste núcleo urbano adiante. Outra citação das autoras, ao tratarem das Aldeias e Acampamentos, contribuirá para a elucidação da origem destes núcleos urbanos:

À época da chegada dos Tupi-Guarani ao novo local, as aldeias deviam ser menores (200 m de diâmetro, no máximo, de acordo com Beltrão (1978) porque correspondiam a um período não só de adaptação às condições locais como de instabilidade, próprio da etapa de apropriação de novos territórios. Quando alcançavam um período de estabilidade, as aldeias chegavam a atingir $600 \mathrm{~m}$ de diâmetro e os locais escolhidos para fixação das aldeias eram aprazíveis, junto aos cursos d'água. Os Tupi dispunham ainda de abrigos ou cabanas provisórias, utilizadas em viagens ou quando em guerra com outros indígenas. (NEME; BELTRÃO, 1993, p. 136).

A citação responde às pequenas aldeias de Ubatuba, encontradas por Anchieta, e às cabanas provisórias de São Sebastião, anotadas por Staden. Mas a justificativa da escolha destas localidades seria, a nosso ver, sua atribuição de "marcas territoriais", suporte dos "meios ofensivos" da intermitente hostilidade guerreira que os Tamoios, especialmente, empreendiam contra os inimigos Tupiniquins. Com a ressalva de que, quando Ubatuba passa a acolher aldeias, esta função, própria da espacialidade dos acampamentos, assume outras feições na paisagem social da tribo. O desenho das localidades litorâneas e de suas articulações territoriais, portanto, reflete as vivências sociais dos seus habitantes. A Figura 14, da página seguinte, contribui para visualizarmos a configuração distinta entre as áreas de ocupação das tribos hostis. 


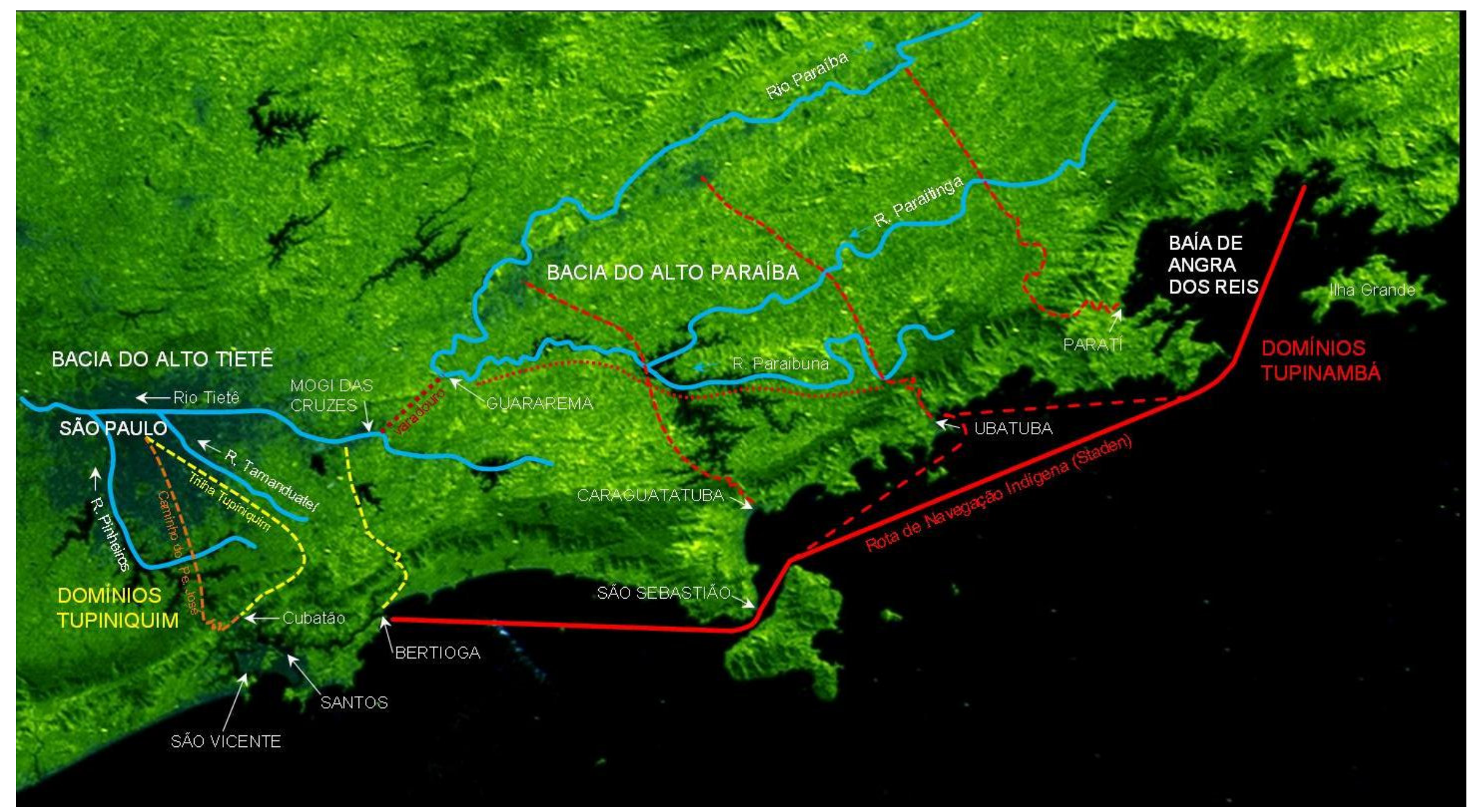

Figura 14. Tupinambá \& Tupiniquim. Interações vivenciais e ambientais nos domínios. Fonte: INPE Sat. Cbers 2000. Acrescentados textos e sinalizações do autor. 
No planalto, a configuração das bacias hidrográficas do Alto Tietê e do Alto Paraíba é delineadora. Estes rios quase se tocam entre Mogi das Cruzes e Guararema. O "incidente" geológico conhecido como "curva de Guararema" reverte radicalmente a direção das águas do Paraíba na sutileza das ondulações típicas do relevo do planalto. Entre as bacias, nenhuma serra, nenhum obstáculo significativo. Permite, portanto, o surgimento do "varadouro", trilha pré-colonial complementar às navegações fluviais, registrada por José de Anchieta. Em carta ao Pe. Diego Laynes, de 30 de julho de 1561, escreve:

Llegados al puerto Del primer rio por onde van, lãs sacan fuara del y lãs llevan a cuestas por quatro o cinco léguas de bosques de muy malos caminos, que a yr descargados ay bien que hazer, hasta lãs tornar a echar em outro rio que está ya em la tierra de los enemigos. (PETRONE, 1965, p. 68).

O primer rio é o Tietê, o outro rio é o Paraíba e los enemigos são os Tupinambás. Quanto a estes, reitera quanto à sua espacialidade:

[...] los contrarios, los quales están tan cerca que em quatro o cinco dias se puede venir de sus terras Estos nunca cessan por mar y por tierra perseguir a los christianos llevándoles sus esclavos y matándolos, y aún a ellos mismos [...]

Este varadouro, elo fundamental na equalização entre os domínios Tupiniquim e Tupinambá, por sua diretriz otimizada no relevo, provavelmente coincide em linhas gerais com o traçado que a antiga Estrada de Ferro Central do Brasil adotou na conexão entre as bacias.

Os ataques por mar e por terra, mencionados pelo jesuíta, evidenciam as articulações territoriais que ambos os grupos exerciam a partir dos seus habitats. A peculiaridade estratégia do varadouro, de merecida atenção, pode ser reiterada por anotação de Hans Staden, que comenta em certo episódio sobre os Tupinambás: "[...] um outro grupo de sua gente, que também se achava em canoas, pelo rio Paraíba, tinha entrado em terra [...]. (STADEN, 1974, p. 125, grifo nosso). Ao 
adotarem a navegação fluvial pelo rio Paraíba, ou por seus formadores, Paraibuna e Paraitinga, a diretriz do inimigo Tupiniquim converge na "curva de Guararema". Do outro lado, a navegação pelo rio Tietê encontra, na localidade de Mogi das Cruzes, as condições adequadas do porto fluvial, antes do estreitamento de suas vertentes. Evidentemente, o embrião dos futuros núcleos urbanos de Mogi e Guararema serão induzidos pelas pontuações dos portos fluviais pregressos ao colonialismo.

No alinhamento litorâneo, a melhor referência etno-histórica para elucidação da ocupação Tupinambá é a narrativa de Hans Staden (1974), singular cronista do século XVI. Sua vivência na capitania vicentina tornou-se célebre por ter ficado nove meses cativo desta tribo em uma das aldeias da baía de Angra dos Reis. Num convívio forçado, deixou precioso registro de seus costumes, com significativas observações sobre os espaços indígenas, suas habitações e seus sítios de ocupação. A clareza com que registra os procedimentos de navegação e os referenciais da paisagem geográfica pode ser justificada pelos seus olhares de mercenário, sua principal atividade. Consegui livrar-se do cativeiro, numa exceção à regra por não ter sido devorado por seus apresadores. Retorna para Marburgo, na atual Alemanha, sua terra natal, onde notabiliza-se ao publicar as amargas impressões das duas viagens ao Brasil, especialmente pelo impacto descritivo da antropofagia. Preciosas xilogravuras ilustrativas da edição prínceps em alemão, de Marburgo, Hesse, no carnaval do ano de 1557, espelham detalhes de sua presença nos ambientes ilustrados, o que não deixa dúvida de terem sido "abertas indubitavelmente sob sua orientação", nos dizeres de Francisco de Assis Carvalho Franco, autor da Introdução da edição por nós estudada, transposição da edição prínceps. 
Havia, ao que parece, um critério logístico nos assédios dos Tupinambás aos Tupiniquins. Staden apresenta duas razões que parecem lógicas das interações ambientais de suas vivências:

Tínhamos que nos acautelar especialmente contra os tupinambás duas vezes por ano, épocas em que, com violência, penetram na região dos tupiniquins. Uma destas épocas é em novembro, quando amadurece o milho, que chamam abati, e com o qual preparam uma bebida chamada cauim. Empregam também aí a raiz de mandioca, de que misturam um pouco. Logo que voltam de sua excursão guerreira com abati maduro, preparam a bebida e devoram nesta ocasião os seus inimigos, se conseguiram aprisionar alguns. Já um ano inteiro antes esperam com alegria o tempo do abati. Além disso, devíamos contar com eles em agosto. Neste tempo procuram uma espécie de peixes que emigram do mar para as correntes de água doce, para aí desovar. Estes peixes se chamam em sua língua piratís e em espanhol "lisas". Nessa época empreendem eles em geral uma excursão guerreira, a-fim-de melhor poderem aprovisionar-se de víveres. Pescam grande número de peixes com pequenas redes. Também os atiram com flechas e trazem muitos assados para casa. Fazem também uma farinha a que chamam piracuí (STADEN, 1974, p. 77, grifo nosso).

O milho, cultivado em Piratininga, e principalmente ao sul pelos Guaranis, em climas adequados, decerto atraía os Tupinambás das planícies quentes do Rio de Janeiro, onde o principal plantio, ao que parece, era da mandioca. Pode ser uma das justificativas das penetrações "por terra". Nos meses do inverno, os Tupiniquins desciam para a marinha em busca da fartura dos nutrientes proteínicos do lagamar vicentino. Fugiam, também, dos rigores do inverno planaltino. Cardumes imensos de tainhas (Staden não as menciona nesta, mas em outras citações) e paratís adentravam pelos estuários da baixada, permitindo uma alternativa alimentar justamente nos períodos de seca dos cultivos do planalto. Esses peixes, nessa época do ano, partem das grandes lagoas do litoral do Rio Grande do Sul em enormes cardumes. Buscam as águas mais quentes ao norte para a desova. Seu regime é cíclico: suas crias retornam ao ecossistema sulino, habitat de alimentação, até que no inverno seguinte retornam para desovar ao longo da costa, alcançando, 
em menor número, até o nordeste brasileiro. Evidentemente, as áreas mais favorecidas de suas aproximações são os recortes costeiros dos lagamares e estuários do sul-sudeste. Entre Santa Catarina e o Rio de Janeiro, as tainhas representavam, até meados do século passado, um dos mais importantes vetores de alimentação das populações caiçaras desta frente atlântica, com forte significado em suas vivências sociais e culturais. Diversos topônimos da costa com a designação de espia, como o morro do Espia em Iguape, ponta do Espia ou pedra do Espia, em tantas localidades, referem-se à figura de um pescador eleito pela comunidade que, em vigília constante, anunciava a entrada dos "corsos" nas barras, tão numerosos que enegreciam a superfície das águas. Era o momento do embarque eufórico dos pescadores nas canoas com suas redes para o cerco dos cardumes. Os espias eram destacados, respeitados por sua atribuição, a quem a comunidade delegava a sorte de suas provisões. O antropólogo Antonio Carlos Diegues (2004), observa:

Apesar da diminuição dos cardumes e do número de pescadores, a
pesca da tainha continua viva em vários pontos do litoral sudeste.
Essa persistência é, de alguma forma, surpreendente uma vez que
seus ganhos financeiros são reduzidos. Uma das explicações
possíveis é que ela faz reviver os valores comunitários e a identidade
dos pescadores caiçaras e açorianos. (DIEGUES, 2004, p. 303).

Se o ritual da pesca da tainha ainda persiste, o que dizer de sua importância no pré-colonialismo? A captura do milho em Piratininga e a disputa da tainha na baixada vicentina são fatores notáveis para as animosidades intertribais. Essa dinâmica de afirmação intermitente, no contexto de suas interações culturais e ambientais, contribuirá para o desenhos de suas ocupações, seqüenciadas no colonialismo. A localidade de São Sebastião, por exemplo, está intrinsecamente associada ao alinhamento da navegação costeira que os Tupinambás praticavam rumo aos combates no litoral vicentino. Daí ser eleito como acampamento. Visava o 
estuário de Bertioga, principal alvo do assédio, o portal mais ao norte do lagamar vicentino.

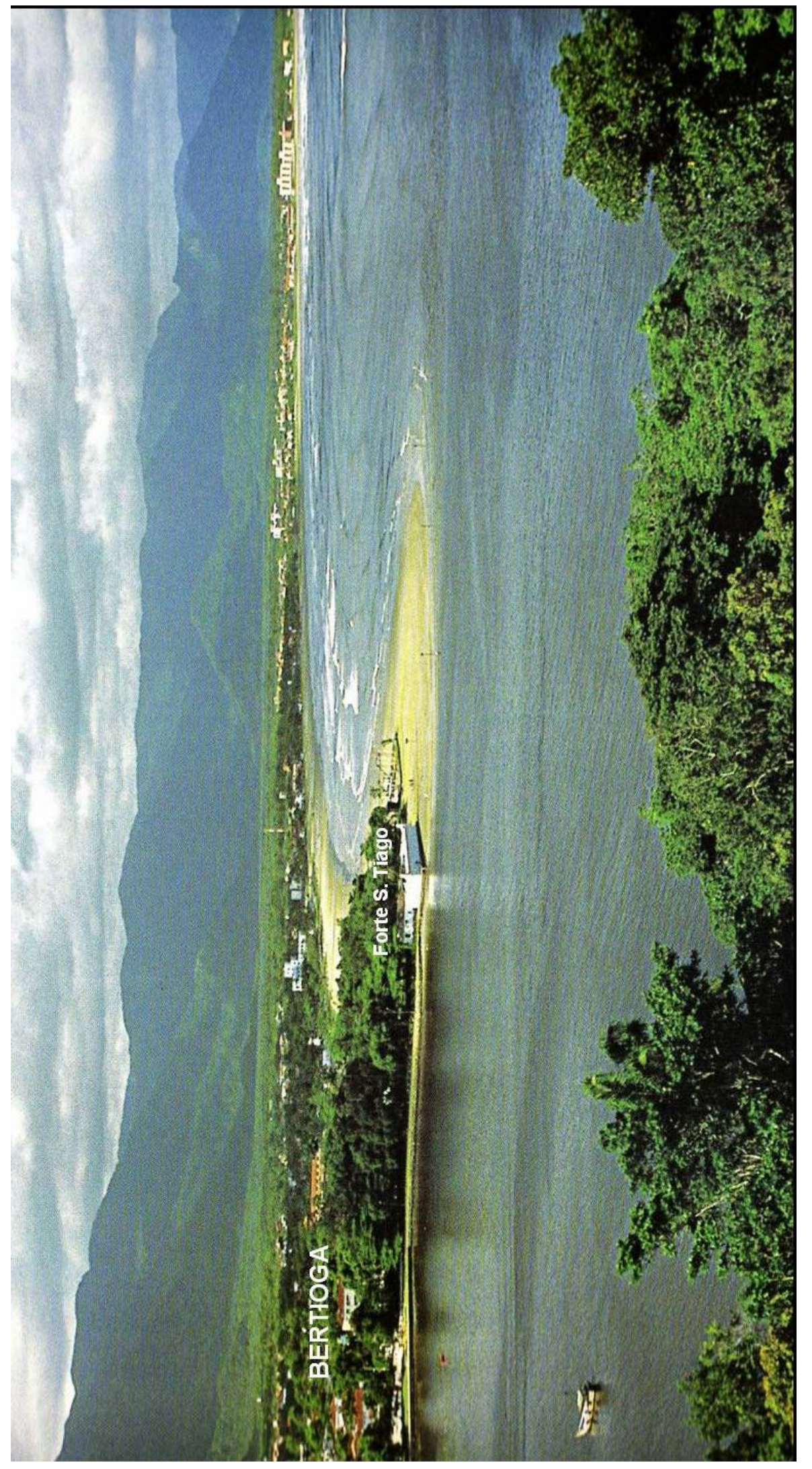

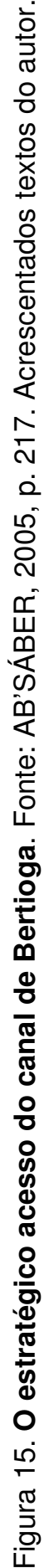


Seu canal de penetração, além da concentração dos cardumes, articulava o sistema fluvial dos arredores da ilha de São Vicente. Não por acaso, foi priorizado nas fortificações da região pelo colonialismo. Neste local, o cronista alemão, contratado para completar e resguardar uma edificação de defesa (ver detalhe figura abaixo), foi aprisionado pelos Tamoios numa emboscada em meados de janeiro de 1554.

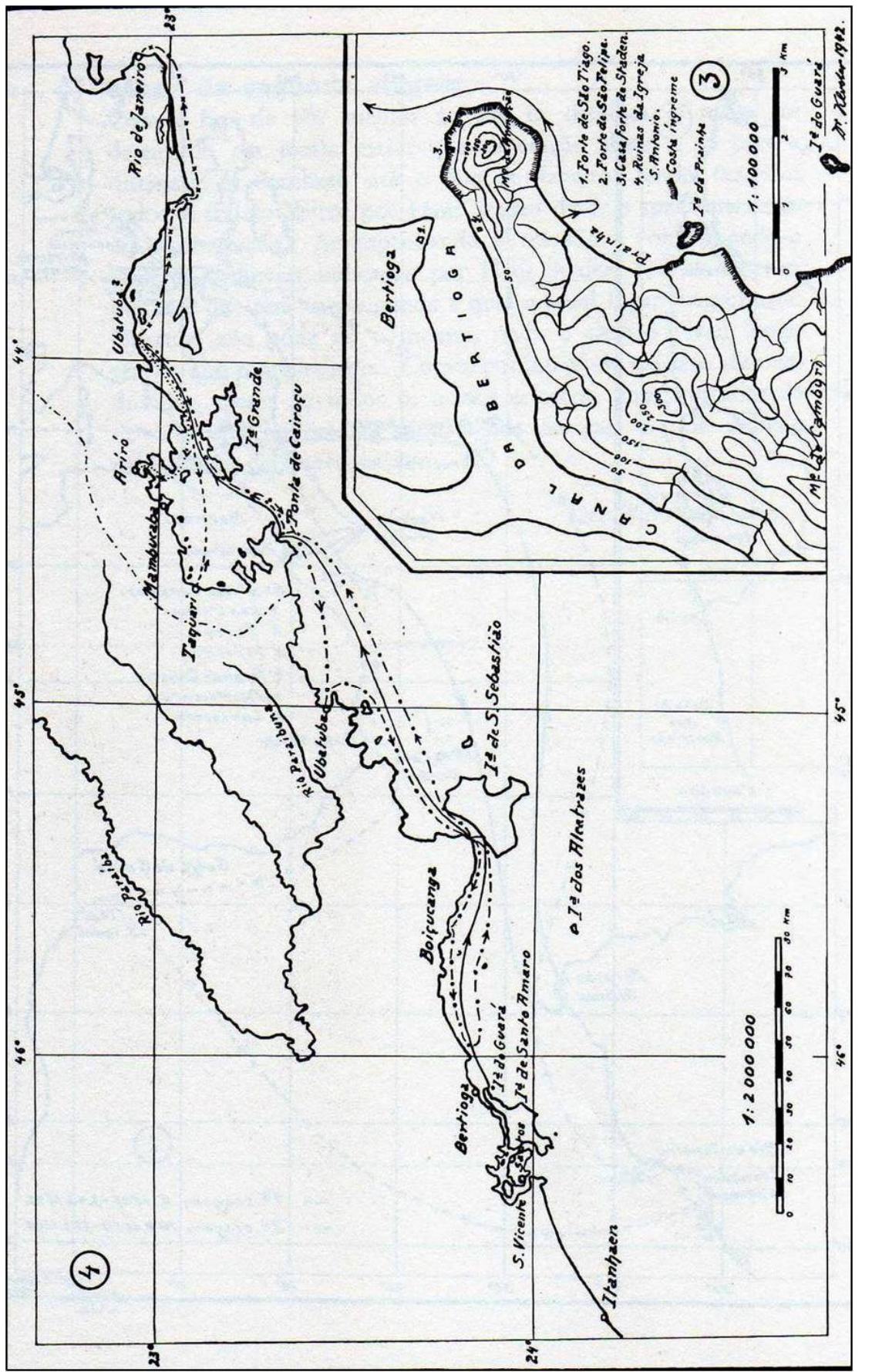


Baseado nas narrativas de Staden, o Dr. Wilhelm Kloster, preparou criterioso mapa dos percursos que o cronista percorreu como prisioneiro, reproduzido acima. O pesquisador, em 1942, elucida com propriedade que a aldeia denominada Ubatuba localizava-se na baía de Angra dos Reis, embora tenha dúvidas sobre sua pontuação. Mas registra a Ubatuba paulista distintamente. As localidades homônimas causam, até hoje, algumas imprecisões na historiografia, embora o texto de Staden seja claro na distinção entre as duas. Observamos neste mapa dos percursos que as localidades escolhidas atendiam a logística da navegação. Os trechos percorridos em canoas a remo, em turnos necessariamente diurnos, eram adequações da velocidade que conseguiam, aliás, surpreendente. Os pousos, portanto, respondiam a uma equação interativa com o ambiente. São Sebastião evidencia esta adequação. Essa lógica fica mais evidente por ocasião do pouso dos viajantes em Ubatuba, ao que parece quando era só um acampamento, veremos adiante. Staden registra que o mau tempo assim os obrigara, ou seja, as condições do mar adverso e o vento contrário, característico nessas ocasiões, impediram a travessia direta para São Sebastião, para onde depois prosseguiram. De qualquer forma, são localidades que atendem aos propósitos sociais dos seus ocupantes, na dinâmica de suas interações ambientais.

Ubatuba é referencial na articulação com o planalto. Sua planície costeira, diferenciada do entorno, avança em cunha nos contrafortes da Serra do Mar. Permite maior extensão, portanto, menor declividade no acesso serrano. No alto, avizinha-se dos rios formadores do Paraíba, articulando quase diretamente a marinha do foco de interesse das circulações do planalto, como observamos anteriormente. A estes recortes pronunciados da Serra do Mar, associam-se, não por acaso, outras localidades litorâneas (Figura 14, p. 65). 


\subsection{0 continente Tupiniquim}

A ocupação Tupiniquim é diferenciada em relação ao alinhamento costeiro. Decerto os atrativos ambientais dos "campos de Piratininga" favoreceram a escolha da região por este grupo de subtradição Tupi. Só o avanço das pesquisas arqueológicas poderá desvendar a especificidade da vertente de sua aproximação com a mesopotâmia do alto Tietê. Quando vemos na Figura 17 abaixo, a mancha da região metropolitana de São Paulo assumir contornos muito próximos do perímetro das aldeias indígenas identificadas, pensamos que as antigas escolhas estavam predestinadas a perpetuarem-se por séculos. Foi o que de fato ocorreu, mesmo com programas sociais tão diferenciados da cultura primitiva. $\mathrm{Na}$ porção inferior da imagem, as ocupações da baixada santista, também de amplitude metropolitana, intrigam pelo diferencial litorâneo, pela permeabilidade das águas do lagamar e pelo perfil abrupto e limitador da Serra do Mar. A polaridade das ocupações é inexorável, mas serão complementares pela diversidade. Entre os nichos ecológicos do litoral e do planalto há uma superposição de atrativos que, complementados, configuram a excelência do habitat, comprovada nos seqüenciamentos históricos, até hoje. A magnitude das regiões metropolitanas de São Paulo e Santos, não é alheia à singularidade das vivências pré-coloniais entre o planalto e a marinha. Podemos dizer, ressalvados conceitos de toda ordem, que aquelas são extensão destas na linha do tempo. Os enquadramentos espaciais foram delineados no pré-colonialismo, em sintonia tão estreita com o meio ambiente que foi inevitável seqüenciá-los. A produção dos espaços, a partir dos contatos euro-indígenas, pela natureza dos objetivos e escala dos programas, só teria, e só teve sucesso quando incorporou os ambientes e assimilou o modo de vida dos habitantes pregressos. 


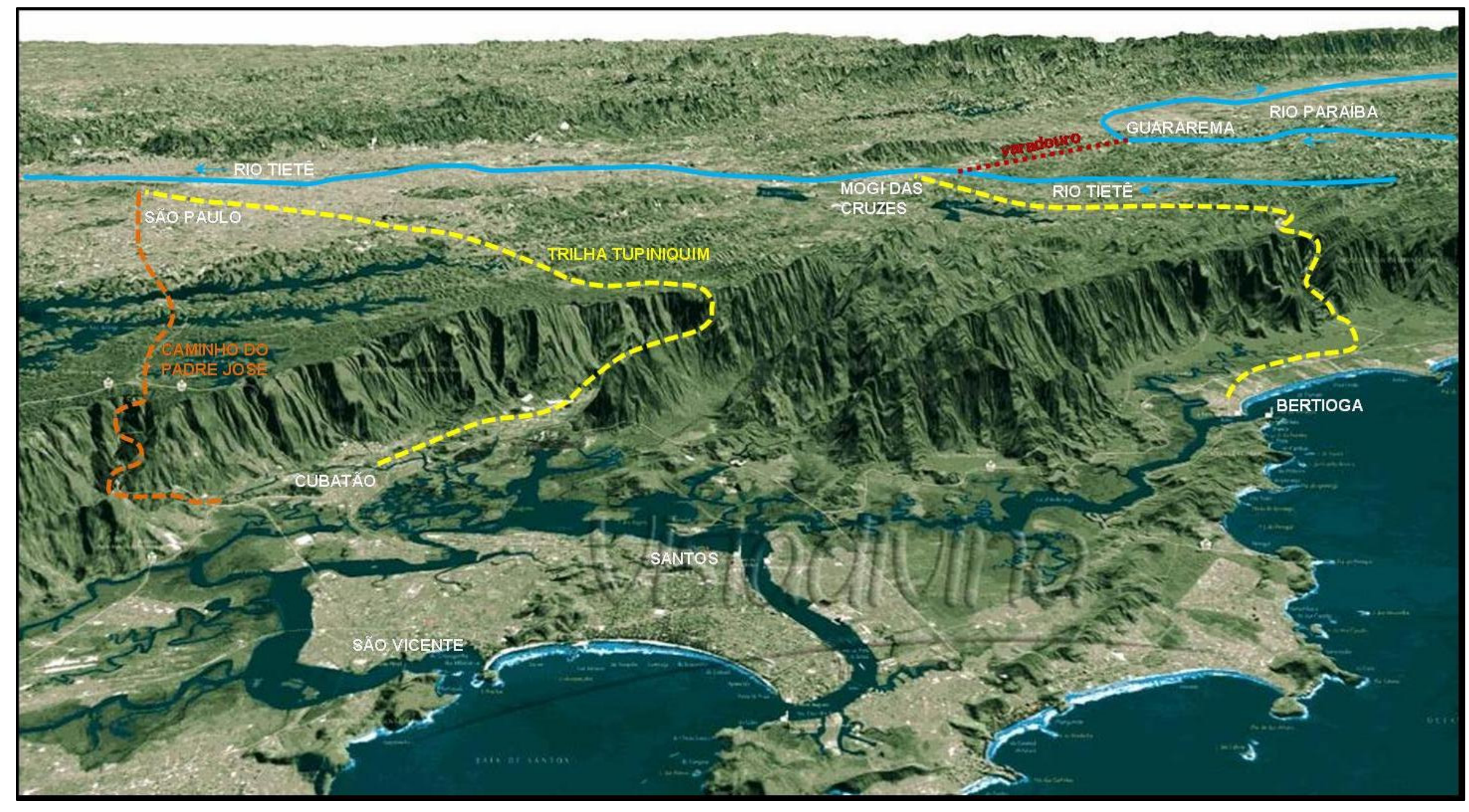

Figura 17. Diversidade. O universo de escolha Tupiniquim consolida-se por séculos. Fonte: www.vistadivina.com. Imagem: Costa dos Fortes. Acrescentados textos e sinalizações do autor. 
No caso das trilhas e caminhos, por exemplo, fomentadores da polarização entre planalto e marinha do habitat Tupiniquim, Sérgio Buarque de Holanda (1994) comenta sobre estas veredas de pé posto:

Neste caso, como em quase tudo, os adventícios deveram habituarse às soluções e muitas vezes aos recursos materiais dos primitivos moradores da terra. Às estreitas veredas e atalhos que estes tinham aberto para uso próprio, nada acrescentariam aqueles de considerável, ao menos durante os primeiros tempos. Para 0 sertanista branco ou mamaluco, o incipiente sistema de viação que aqui encontrou foi um auxiliar tão prestimoso e necessário como o fora para o indígena (HOLANDA, 1994, p. 19).

Estes componentes de ocupação, somados às vias fluviais, não limitam-se ao espaço circunscrito da tribo. Piratininga irradia um arco de articulações regionais em todas as direções do horizonte continental, enquanto a vertente oceânica agrega atrativos na diversidade do seu recorte costeiro. Estes fatores já compunham o repertório de percepções da sociedade indígena, integravam o universo de suas escolhas e vivências. Serão, portanto, angulares nos seqüenciamentos sociais futuros.

Quando os engenheiros ingleses da São Paulo Railway desembarcaram em Santos na metade do século XIX, descortinaram a Serra do Mar e logo perceberam seu maior desafio: romper seus contrafortes com o mais moderno e sofisticado meio de transporte terrestre que se conhecia, a ferrovia. A nova tecnologia não prescindia de uma opção geométrica banal: a equalização entre a menor distância de percurso possível e a maior declividade permitida aos seus trilhos. Após investigações, levantamentos, cálculos e reflexões, optaram pela mesma vereda da secular Trilha Tupiniquim. A ciência européia escolheu, para os seus meios, o que talvez sempre tenha sido: o mais natural dos caminhos para o planalto de Piratininga. Partindo da baixada, no local denominado "porto Piassaguera de cima", subia pelo vale do rio Mogi (ou Quilombo) até o espigão serrano. Segundo Petrone: 
[...] [o] trecho planaltino [também] corresponde aproximadamente ao da atual ferrovia São Paulo-Santos (antiga São Paulo Railway). Dessa forma, atingindo o alto da Serra, o caminho aproveitaria inicialmente um trecho do vale do rio Grande para, em seguida, penetrar, após superado o divisor de águas, no vale do Tamanduateí (antigo Piratininga), por seu intermédio chegando até São Paulo. (PETRONE, 1965, p. 56).

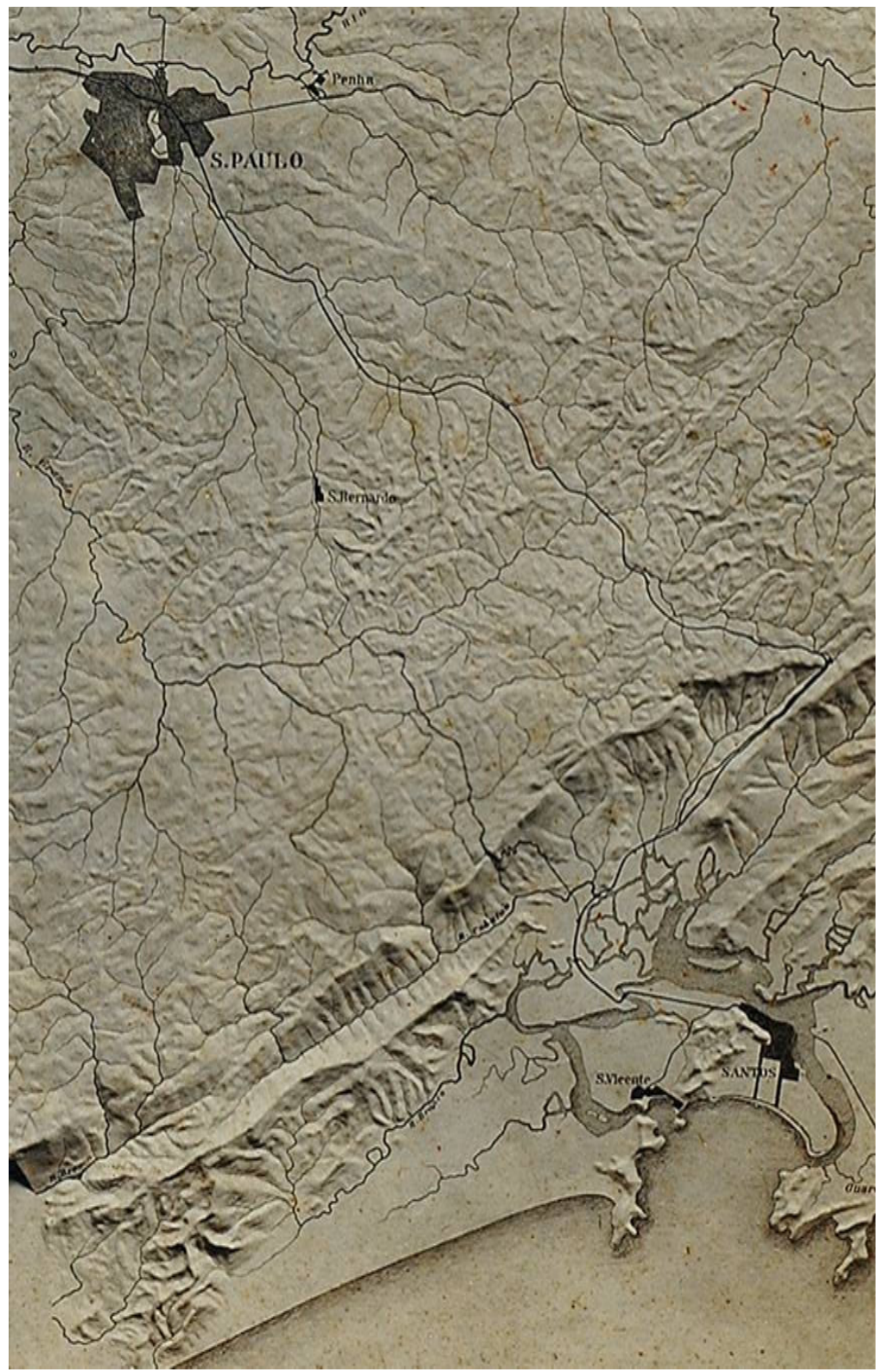

Figura 18. A trilha dos trilhos da São Paulo Railway. Superposição de séculos a caminho do planalto. Foto da maquete do relevo "São Paulo and Santos", da Comissão Geográfica e Geológica do Estado de São Paulo, início do século XX. Fonte: Museu Paulista - autorização Of.459/05

Após 1560 este caminho foi abandonado por determinação do Governador Mem de Sá, ao que tudo indica por ser mais vulnerável aos ataques tamoios 
provenientes do leste, bem como pela desativação da Vila de Santo André. O Caminho do Padre José substitui a Trilha Tupiniquim e perdura a duras penas até o final do século XVIII. Recupera, todavia, outra antiga trilha indígena desativada. Segundo Adolpho Augusto Pinto, Anchieta "[...] lançou o novo caminho por um trilho feito também pelos índios [...]." (PETRONE, 1965, p. 58).

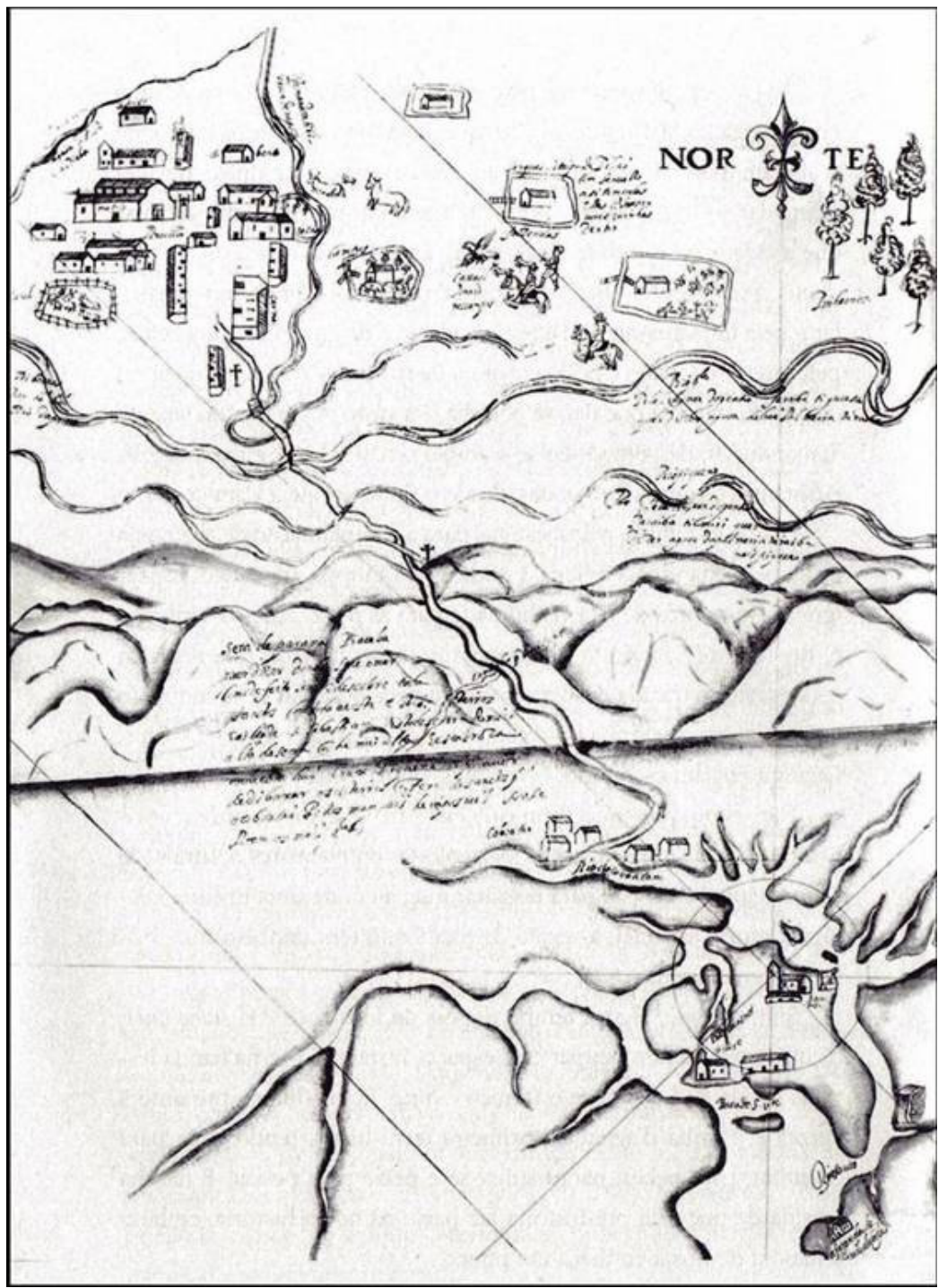

Figura 19. Os lugares de vivência. Notar a importância do elo planalto-baixada acentuada no desenho do "caminho do Padre José" e no povoado de Cubatão, porto de "pé de serra". Detalhe de mapa vicentino, autor anônimo, elaborado entre 1610 e 1640. Talvez a primeira representação do intra-urbano de São Paulo, com predominância dos edifícios religiosos. Fonte: AB'SABER, 2004, p.46. 
Atribui-se erroneamente a abertura deste caminho ao noviço jesuíta; quem sabe empenhou-se na sua recuperação junto aos índios que o conheciam. Passou a ser referenciado com seu nome, mas a trilha era secular.

É preciso salientar o diferencial de ocupação da tribo entre o planalto e marinha, contextos do mesmo habitat. A historiografia costuma generalizar a presença Tupiniquim no ambiente vicentino. $O$ enquadramento espacial maculado dificulta a elucidação da dinâmica dos seus processos sociais. Não há registros de aldeias ou sítios de habitação no litoral. O grupos locais, ao que se sabe, estavam assentados somente no planalto. A presença do grupo na baixada era sazonal, obedecia a um ciclo ditado pelo clima, no caso o período do inverno, como dissemos. Estas localidades, eleitas como acampamentos, possivelmente eram selecionadas em função dos cercos pesqueiros da tainha, dos terrenos "enxutos" (nos dizeres de Frei Gaspar), da vizinhança dos mangues para coleta de crustáceos e moluscos (caranguejos, mariscos, ostras, etc), da disponibilidade de água doce, da proteção dos ventos invernais do sul e da estratégia de defesa dos inimigos Tupinambás. Podemos dizer que, embora não fossem aldeias, seus atrativos fundamentais seriam os mesmos, levando-se em conta a relativa permanência.

O geógrafo Pasquale Petrone (1965), ao tratar das atividades de subsistência da tribo, acena com esta caracterização:

Por outro lado, é preciso considerar que a mobilidade não deve ser observada apenas em função do nomadismo mas, também, e principalmente, em função dos movimentos dentro da área de subsistência, geralmente com características rítmicas. É quando se verificaria, por exemplo, no relativo à pesca. Os Guaianá do planalto não praticavam a pesca somente nos rios, mas também a beira-mar. Especialmente no decorrer do inverno, grupos inteiros deslocar-seiam em busca do mar, com o objetivo de praticar a pesca. Terminada essa estação, voltariam para o planalto. [...] A marinha não era, portanto [...], área de povoamento estável ou, considerada a hipótese contrária, não poderia ser comparada ao planalto quanto à importância do povoamento indígena. (PETRONE, 1965, p. 25). 
E cita o historiador beneditino Frei Gaspar Madre de Deus, que em 1797 escreveu:

"Este território, e toda a Costa circunvizinha, assim para o Norte, como para o Sul, pertencia a várias Aldeias situadas no campo, sôbre as Serras; as Ilhas de S. Vicente e Santo Amaro, e também a terra firme adjacente e suas praias, defendiam os índios, pela única conveniência de nelas pescarem e mariscarem"... "Índios particulares, em todo o tempo, e povos inteiros, em certos meses vinham mariscar na costa: escolhiam entre os Mangais algum lugar enxuto, onde se arranchavam e dali saiam como enxames de abelhas a extrair do lodo os testáceos”... (PETRONE, 1965, p. 26).

A arqueóloga Maria Cristina Scatamacchia também cita Frei Gaspar como testemunho da inexistência de aldeias no litoral central de São Paulo:

"Nos arquivos e Sesmarias, onde a cada passo se encontram aldeias situadas noutras partes, não acho o menor vestígio de alguma na mencionada porção da costa: as primeiras de que estavam adiante do rio Itanhaem, e nenhuma acho para o norte, antes de chegar à Enseada dos Maramomis" (SCATAMACCHIA, 1990, p. 193).

Essa notável particularidade do habitat Tupiniquim elucida os passos do colonialismo nesta frente atlântica a partir dos contatos euro-indígenas. A interiorização vicentina sempre foi tratada como "exceção" do modelo estritamente litorâneo da colônia brasileira sob os olhares das estruturas econômicas do mercantilismo. Segundo Nestor Goulart Reis Filho (1968),

Os núcleos urbanos estabelecidos nos primeiros séculos da colonização brasileira situavam-se, de modo predominante, no litoral, por razões econômicas, administrativas e militares. Exceção fizeram apenas as vilas do planalto paulista. O sistema econômico ao qual a Colônia era vinculada, baseado na divisão internacional do trabalho fazia com que os núcleos dependessem estreitamente das comunicações com a Metrópole. (REIS FILHO, 1968, p. 122).

Com o mesmo referencial de análise, Pasquale Petrone (1965), escreve:

O planalto paulista não atraiu pelas riquezas em metais que pudesse fornecer. Portanto, o processo de colonização no litoral vicentino deve ser considerado, sem dúvida, como uma exceção dentro dos quadros de expansão colonial no mundo tropical. (PETRONE, 1965, p. 20). 
A seguir, procurando compreender as razões dessa particularidade, este autor aproxima-se das ocupações pregressas ao colonialismo. Identifica caminhos, instalações e vivências indígenas, mas não encontra nas interações sociais, culturais e ambientais das sociedades, anteriores e subseqüentes aos contatos, o sentido e a representação dos seus espaços.

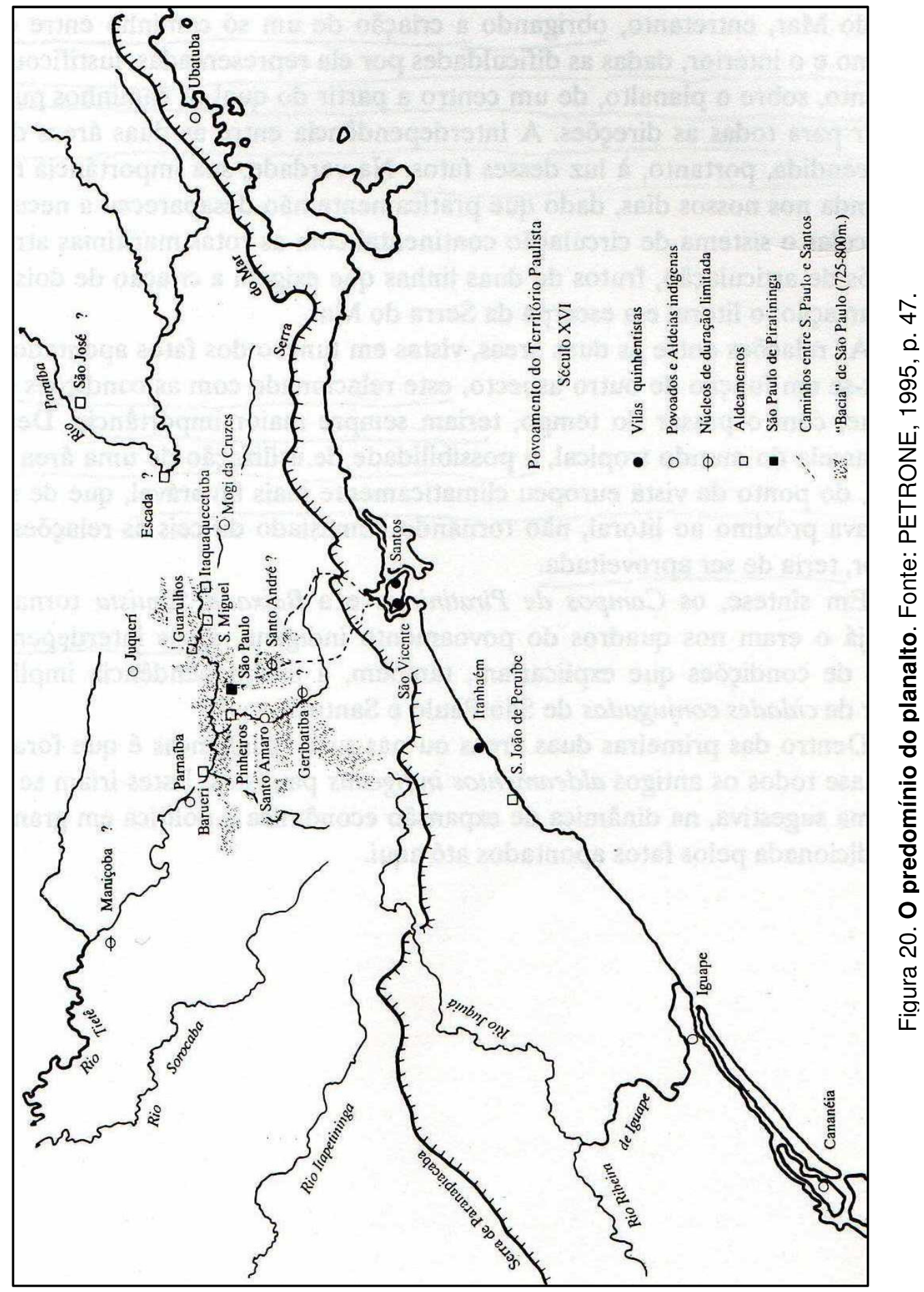


O predomínio Tupiniquim no planalto, eleito como área de assentamento de suas aldeias, decerto norteou a presença dos europeus serra acima. Acolhidos pela receptividade indígena, os ibéricos pioneiros, provavelmente degredados, e os primeiros colonos deixados aqui por Martim Afonso em 1533, antes mesmo do projeto colonizador das Capitanias Hereditárias (1534), incorporaram significativamente o modo de vida das sociedades pré-coloniais. O caso de João Ramalho é esclarecedor. Genro do cacique Tibiriçá, vivia no planalto com seus pares. Chega na região, ao que se sabe, entre 1510 e 1512. Mesmo depois da formação dos núcleos urbanos de Santo André e São Paulo, continua a viver no seu reduto tribal, onde notabiliza-se pela liderança. Atua, em alguns momentos, ao que parece com reservas, na gestão do colonialismo. Outros portugueses viviam no planalto, provavelmente fruto das sesmarias outorgadas por Martim Afonso, em comunhão estreita com os indígenas, dispersos em suas aldeias ou em propriedades rurais embrionárias. Foi o quadro que assombrou o padre jesuíta Leonardo Nunes ao subir a serra: os imigrantes (homens, na expedição de Martim Afonso não havia mulheres) estavam muito aquém do comportamento cristão, vivendo como índios, desencadeando uma prole de mamelucos que, pela prática do cunhadismo (poligamia extensiva às irmãs das esposas) deveria progredir geometricamente... Leonardo Nunes percebeu que teria mais trabalho na recuperação dos cristãos do que na conversão dos gentios. Com o esforço possível junto aos habitantes, liderou a construção de uma capela em devoção a Santo André. Escolheu um local provavelmente notável ao longo da Trilha dos Tupiniquins com o objetivo de arrebanhar os portugueses dispersos pelo planalto. Foi em novembro de 1550 que o jesuíta narrou esta façanha na Carta do $P$. Leonardo Nunes aos Padres e Irmãos da Companhia (LEITE, 1954, p. 200), escrita na vila de 
São Vicente onde organizara a casa e colégio da Companhia por determinação de Manuel da Nóbrega, que permanecia em Salvador desde que chegaram com a esquadra de Tomé de Souza.

Os desdobramentos da escolha desta localidade são significativos. A intenção, claramente expressa, foi explicitada. Não foi catequizadora, atividade que se iniciava em São Vicente. Compreende-se a neutralidade do local da ermida em relação às aldeias e sua estratégia pela convergência dos domínios de Piratininga no polarizador caminho da marinha. O pequeno edifício religioso foi semente germinal do colonialismo no planalto. Em 1553, quando o governador Tomé de Souza e comitiva sobem a Trilha Tupiniquim dispostos a fundar uma vila serra acima, os atrativos de Piratininga certamente consolidavam-se na percepção dos adventícios, entre colonos, administradores e evangelizadores. Santo André foi uma demonstração clara de afirmação do poder no planalto. Sua formalização seguiu os rituais da administração reinol: na comitiva do governador estavam Antonio de Oliveira, loco-tenente do donatário (Martim Afonso), a quem coube as providências práticas como instalação do pelourinho, o provedor da Fazenda Brás Cubas, e João Ramalho, que vivia em reduto próximo, nomeado alcaide-mor da vila. (LUÍS, 1980, p. 81). Que razões teriam levado o representante da corte e os notáveis da capitania serra acima para tal fim? A motivação não parece vinculada ao expansionismo ou substituição da produção agrário-exportadora praticada em pequena escala na baixada vicentina, ao menos não há registro de engenhos significativos no planalto que poderiam ser associados à premência da vila. Mesmo porque, as dificuldades de escoamento da produção, relativas à disponibilidade de áreas em toda costa, não justificariam tal empresa. Ainda, um dilema certamente acompanhou Tomé de Souza 
nos solavancos de sua liteira na subida da serra de Paranapiacaba4: a tenaz proibição da corte à interiorização do colonialismo nessa frente atlântica. João Ramalho já fora nomeado guarda-mor do campo por Martin Afonso, quando aqui esteve, com a determinação de impedir penetrações de colonos no sertão. O próprio governador, reiterando esta postura, impede que o amigo Manuel da Nóbrega realize seu sonho de avançar nos horizontes Guaranis da mesopotâmia paraguaia. Outro governador geral, Mem de Sá, quando esteve em Piratininga em 1560, reafirma os mesmos propósitos, o que não deixa dúvida tratar-se de uma política do Estado português, ainda pouco elucidada. Então por que fundar uma vila no planalto? Talvez o olhar missionário do Pe. Leonardo Nunes tenha detectado o problema: os primeiros colonos interagiam socialmente com a determinante presença Tupiniquim no planalto num encadeamento que parecia irreversível. A ermida representaria o resgate dos valores culturais que se dissipavam. Tomé de Souza reitera a iniciativa, simbolicamente no mesmo espaço, tentando resgatar o manto dos seus poderes:

[...] e ordenei outra vila no começo do campo desta vila de S. Vicente de moradores que estavam espalhados por ele e os fiz cercar e ajuntar para se poderem aproveitar todas as povoações deste campo e se chama vila de Santo-André porque onde a situei estava uma ermida deste apostolo e fiz capitão dela a João Ramalho, natural do termo de Coimbra, que Martim Afonso já achou nesta terra quando cá veio. (LUÍS, 1980, p. 80, trecho de carta a D. João III).

Este episódio ocorre em 8 de abril de 1553, data de fundação da vila. O sítio de Santo André, nada a ver com a cidade atual, foi nitidamente escolhido pelos colonizadores. Embora apensado na Trilha Tupiniquim, foi estrategicamente isolado das "povoações deste campo", simbolizando assim a valorização e a representação da identidade ibérica. Todavia, o alheamento dos vetores sociais e ambientais consagrados pela sociedade pregressa pode ter sido a causa do seu insucesso.

\footnotetext{
${ }^{4}$ De paraná-apiacaba = lugar de onde se avista o mar (BUENO, 1983, p. 544).
} 
Poucos anos foram suficientes para que o procurador da câmara, em vereança de 20 de setembro de 1557, proponha: "[...] como estavam em esta dita vila e morriam de fome e passavam muito mal e morriam o gado... que se fossem dentro do termo dela de longo dalgum rio [...]." (NEME, 1959, p. 178).

A gênese de São Paulo também será comprometida pela paisagem social e ambiental de Piratininga. Quando o padre Manuel da Nóbrega - nomeado Provincial do Brasil por Inácio de Loyola, fundador da Ordem Jesuítica em 1539 - chega a São Vicente com o governador Tomé de Souza, em fevereiro de 1553, encontra o irmão Leonardo Nunes desolado. A missão jesuíta na vila passa por privações. A recém fundada Companhia, iniciando a evangelização da colônia, dependia de esmolas e soldos da coroa portuguesa, que não deveriam ser promissores na pobre Capitania. Algumas crianças índias permaneciam na casa, evidentemente dependendo das ações dos religiosos para sobreviver. Manuel da Nóbrega entendeu que a missão não tinha que estar ali. Podemos compreender facilmente: naquela estação do verão, como em outras, o principal contingente indígena deveria estar no planalto. Leonardo Nunes deve ter amargado a sazonalidade dos catecúmenos desde 1550 enquanto seu superior não chegava para as decisões. Alguns anos depois Nóbrega reporta-se ao problema em carta de maio de 1556:

"a todos era muito dificultoso, e obrigava-nos a cousas que não eram
de nosso Instituto, porque a mantença dêles, e na terra haver poucas
esmolas para tanta gente, foi-me forçado, des que a esta Capitania
vim a passar os meninos a uma povoação de seus pais, donde eram
maior parte dêles, e com êles passei alguns Irmãos e fizemos casa e
Igreja, e tivemos conosco sòmente alguns que eram de outras
partes". (NEME, 1959, p. 150 , grifo nosso). O ano de 1553 foi decisivo para o destino da capitania. Sabemos, por outra carta do missionário, de setembro-outubro de 1953, que a generosa colina da confluência do córrego Anhangabaú com o rio Tamanduateí já acolhia simplórias 
instalações jesuíticas, embrionárias da futura metrópole: "[...] e vai-se fazendo uma formosa povoação [...]”. (NEME, 1959, p. 149). Nóbrega não instala o Colégio na recém elevada vila de Santo André. A pretensão era estar próximo dos índios, um tanto assombrado com o comportamento indecoroso dos portugueses que aqui aportavam: "[...] e por isso digo que quanto mais longe estivermos dos velhos cristãos, que aqui há, tanto se fará mais fruto [...].” (NEME, 1959, p. 150). São indicativos para nossa suposição de que o Colégio de São Paulo de Piratininga, instalado onde sabemos, partilha o platô da colina com os principais assentamentos Tupiniquins naquele período. A providência de suas instalações parece coincidir com o término do inverno, quando a população indígena retorna ao planalto, conforme a data da carta acima. Sem a conivência dos principais da tribo não se efetivaria. A localização do Colégio é um indicativo desta presença, pois os jesuítas acabavam de contornar a dificuldade do isolamento de São Vicente. Um testemunho significativo também sinaliza que a futura sede da vila seqüencia sítio de escolha pré-colonial. A Carta do P. Luis da Grã ao P. Inacio de Loyola, escrita em Piratininga, com data de 07 de Abril de 1557, deixa claro o agenciamento espacial e registra um evento próprio da dinâmica sócio-ambiental da sociedade primeva:

El Padre Nobrega quando de aqui se fué dexó esta Aldea en que está esta Casa de Piratininga poblada de los Indios, en los quales avía muchos ia christianos y muchos cathecumenos. Pero ellos son tán costumbrados a se mudar como sus casas son viejas [...] Assi fué en este pueblo, que sola una casa quedo em que avrá cinquo o seis hombres casados; mudarsean como su casa caiere [...]." (LEITE, 1954, p. 200).

O velho hábito indígena deve ter deixado os missionários perplexos. Anchieta estava presente. Da noite para o dia a efervescente colina ficou vazia. Observe-se que Luis da Grã refere-se à "Aldea en que está esta Casa de Piratininga". Este episódio muda os rumos do Colégio e de Santo André. Um arranjo político, com forte 
participação de Nóbrega em Salvador, contorna os descompassos concomitantes de ambas as instalações. Os moradores da vila transferem-se para a colina no entorno do colégio, ao que parece com pelourinho e tudo, ou seja, a constituição jurídica da vila de Santo André muda de sede física, dentro do seu termo. O Colégio muda o foco do ensino para os filhos dos colonos e São Paulo seguirá o seu destino. Esse processo é coroado com a presença do Governador Mem de Sá em Piratininga em 1560, quando a vila de Santo André é desativada e a Trilha Tupiniquim substituída pelo Caminho do Padre José. Em carta de junho de 1560, Anchieta registra: "[...] e em lugar dos catecúmenos, que de Piratininga se foram, vieram outros de diversos lugares, que se vieram unir segundo a vida cristã, fizeram casas de taipa para sempre morarem [...]." (NEME, 1959, p. 182). 


\section{NOVOS TEMPOS}

\subsection{Os primeiros olhares}

D. Manoel, com as notícias enviadas por Pero Vaz de Caminha, providencia uma expedição para conhecer melhor a extensão dos seus domínios. A historiografia encarregou-se de batizá-la como "Expedição Reconhecedora da Costa". O Rei não poupou esforços para que fosse criteriosa nos seus registros: contratou o cosmógrafo florentino Américo Vespúcio para integrar a esquadra de três caravelas comandada pelo capitão Gonçalo Coelho. Percorreriam a descoberta que só então revelou aos europeus sua amplitude continental. Vespúcio, por sua formação erudita, com trânsito em diversas cortes européias, talvez tenha sido um dos mais significativos "olhares" voltados ao Mundus Novus. Com este título escreve uma carta dirigida a Lorenzo de Medici, em 1503, onde registra suas impressões. A primeira exploração oficial do Brasil parte de Lisboa em 14 de maio de 1501. Identifica e mapeia a costa Leste brasileira de Norte a Sul, assinalando os principais portos (estuários dos rios, baías e enseadas), fundamentais para futuros projetos de posse, exploração e fixação nos novos domínios. Munidos de um calendário litúrgico, batizam os acidentes costeiros, o que nos permite acompanhar as arribadas da expedição. Ao adentrarem na baía da Guanabara no primeiro dia de 1502, pensando tratar-se de um estuário fluvial, denominam a localidade como Rio de Janeiro; No "dia de Reis" (6 de janeiro), decerto aportaram na baía de Angra dos Reis; no dia 20 conheceram a ilha de São Sebastião e no dia 22 a ilha de São Vicente. Depois aportam em Cananéia, exceção do calendário litúrgico. Afastam-se da costa num grande arco adequado aos ventos e correntes do Atlântico Sul e 
retornam a Portugal. Alguns registros do eminente renascentista na Carta Mundus

Novus são pertinentes:

[...] e os que afirmaram haver aí terra negaram que fosse habitada de racionais. Mas o ser esta opinião falsa, e a verdade o contrário, se provou nesta minha última viagem, pois naqueles meridianos encontrei terra continental habitada de mais povos e animais que a nossa Europa [...]. Navegamos [...] baixando muitas vezes em terra, tratando com os habitantes, e sendo bem recebidos e morando com eles amigavelmente às vezes quinze e vinte dias [...]. E por certo que se o paraíso terreal existe em alguma parte da terra, creio que não deve ser longe destes países [...]. (RIBEIRO, 1993, p. 101).

A visão edênica, todavia, não foi suficiente para aplacar a imagem dantesca

da antropofagia incorporada ao repertório dos seus olhares.

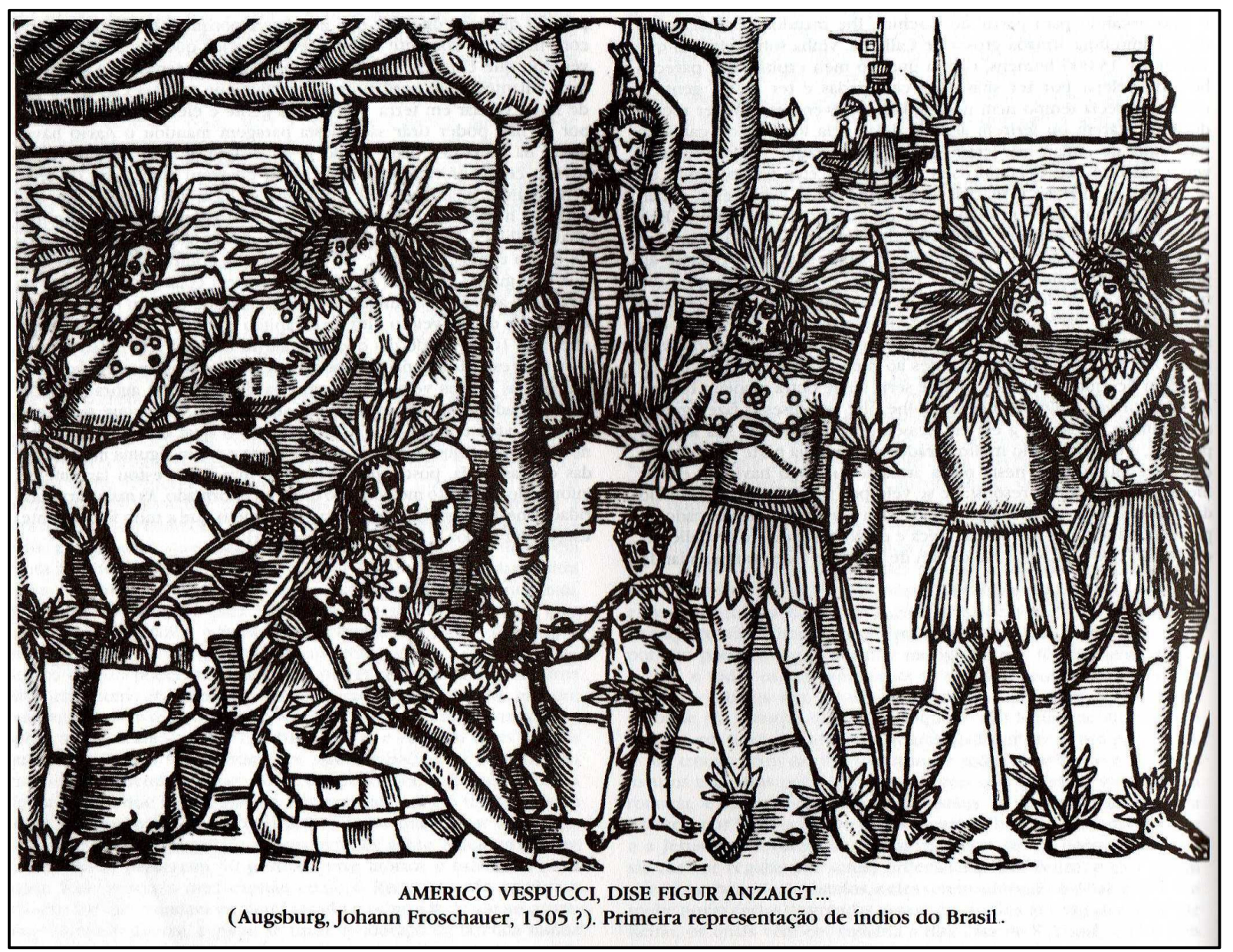

Figura 21. "Os habitantes". "[...] expressiva xilogravura retrata os hábitos antropofágicos dos índios da costa do Brasil [...]." Fonte: RIBEIRO, 1993, p. 98. 


\subsection{Os primeiros levantamentos}

A partir do século XVIII, a "[...] cartografia perde definitivamente o caráter decorativo em benefício da precisão científica” (BUENO, 2003, Cap. V). Os territórios do reino e das conquistas ultramarinas precisavam ser mapeados, demarcados. Os mapas foram instrumentos eficientes de ação política. Mapear significava "conhecer", "domesticar", "submeter", "conquistar", "contradizer a ordem da natureza". Segundo a historiadora Beatriz Piccolotto Siqueira Bueno, ao conceito de 'lugar' do índio (cuja toponímia reflete uma profunda vivência do mesmo, expressando o seu caráter), sobrepôs-se o abstrato conceito de 'território' do europeu, com fronteiras politicamente acordadas e demarcadas pelas nações ibéricas (BUENO, 2003, Cap. V). A partir do século XVIII, os levantamentos geográficos, corográficos e topográficos ganham mais precisão, ao disporem de métodos e instrumentos que permitem equacionar problemas técnicos de levantamento e representação cartográfica. A formação dos engenheiros militares envolve, desde então, conhecimentos específicos de geometria elementar e geometria prática, bem como de astronomia. Seguindo padrões franceses, uma série de tratados portugueses, como os do engenheiro-mor do reino Manoel de Azevedo Fortes - "Tratado do modo o mais facil e exacto de fazser as cartas geographicas ..." (1722) e "O Engenheiro Portuguez" (1728) - atestam o emprego desses novos procedimentos matemáticos na representação cartográfica. Uma série de códigos e convenções de representação é estabelecida de modo a permitir um entendimento mais objetivo das cartas. A criação de um relógio portátil capaz de registrar as horas sem oscilações, pelo inglês John Harrison, em 1770, põe fim ao difícil problema de equacionamento da longitude. Nesse sentido, as coordenadas geográficas - 
paralelos e meridianos - melhor definidas permitem configurar representações bidimensionais mais próximas da complexa realidade tridimensional.

Nesse quadro, nossa frente atlântica será representada em preciosa "Carta Corographica e Hydrographica de toda costa do mar da Capitania de São Paulo". Trata-se de um mapeamento regional encomendado pelo então Governador Bernardo José de Lorena ao engenheiro militar João da Costa Ferreira que, com seus auxiliares Antonio Rodrigues Montesinhos (engenheiro militar), Francisco de Oliveira Barbosa e Bento Sanches D'Orta (astrônomos), procede, a partir de 1789, a minucioso levantamento da costa. O levantamento delineia a faixa litorânea até os contrafortes da Serra do Mar, articulada com a cidade de São Paulo (Figura 23, p. 91). A vilas litorâneas, destacadas em Plantas Topographicas, são fontes foram documentais angulares para os nossos estudos.

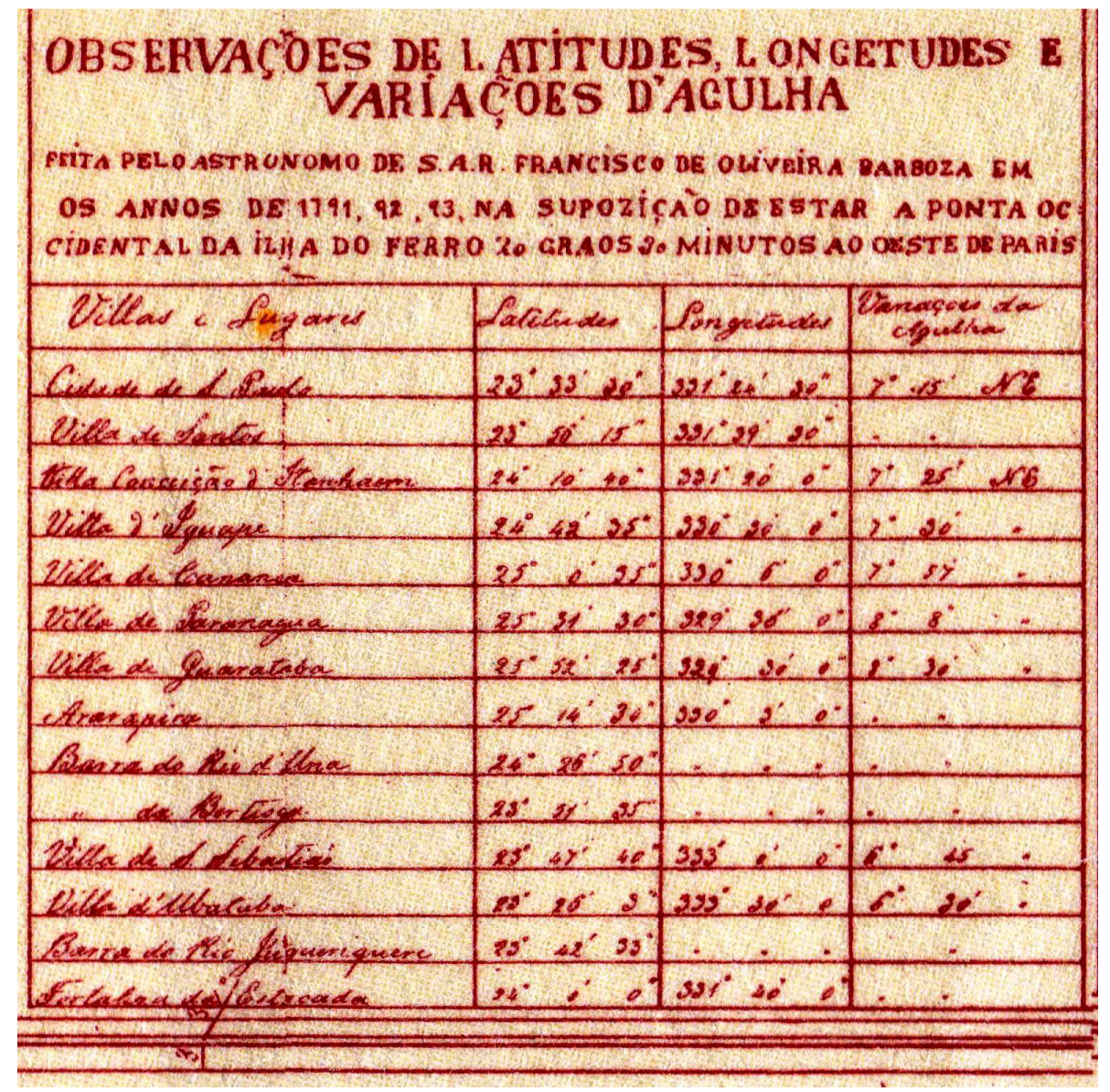

Figura 22. A certificação das localidades. Det. da Legenda da Carta Corographica e Hydrographica... apresentada na Figura 23. Fonte: TOLEDO, 1981, p. 93. 


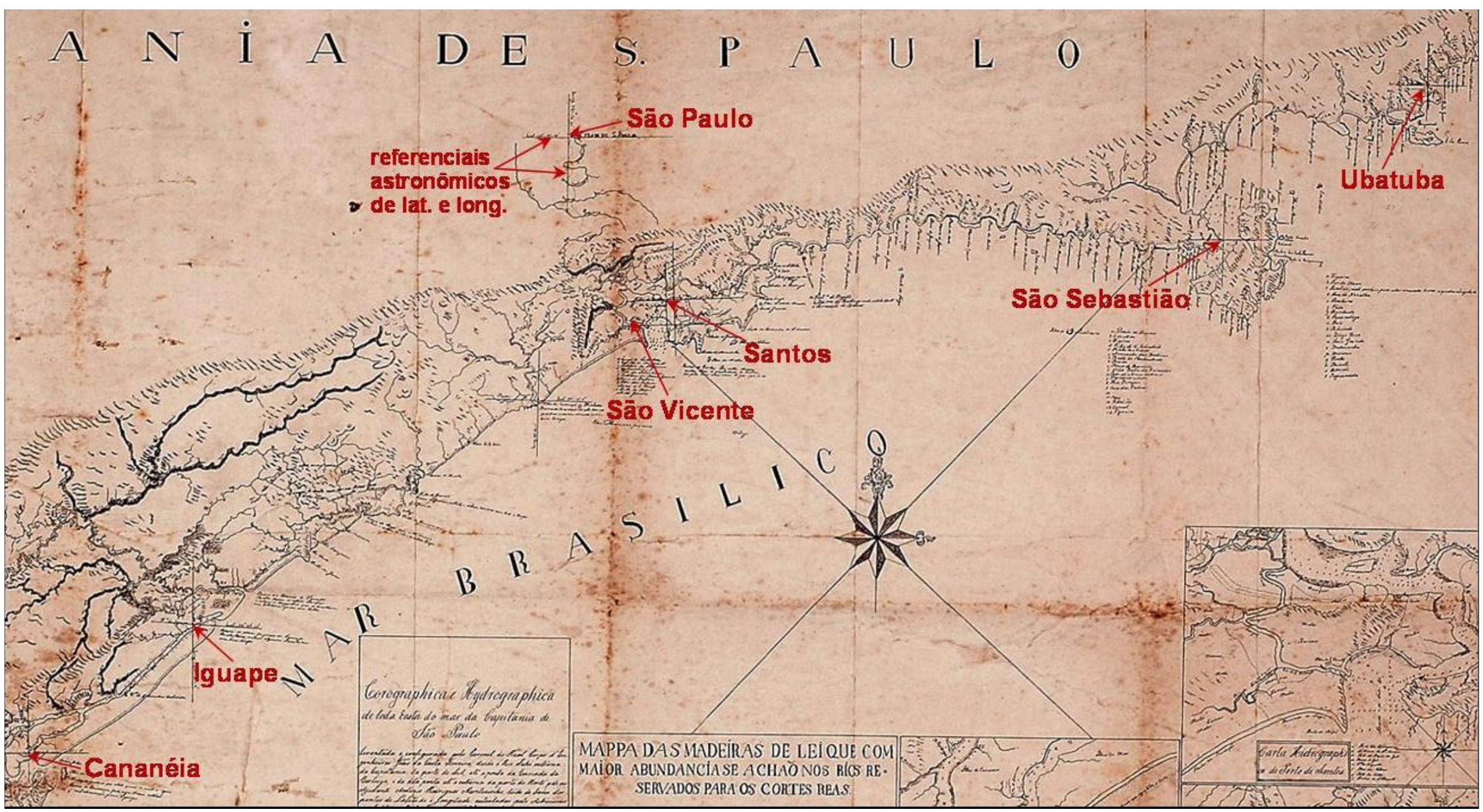

Figura 23. A costa paulista. Detalhe da Carta Corographica e Hydrographica de toda a costa do mar da Capitania de São Paulo. Trata-se de pioneiro levantamento regional. Além dessa carta geral, as Villas assinaladas em cruz (referências de latitude e longitude), foram destacadas em Plantas Topographicas, com exceção de São Vicente, não contemplada. Fonte dessa Carta: Museu Paulista - autorização conforme Ofício 459/05. Acrescentados textos e sinalizações do autor. 


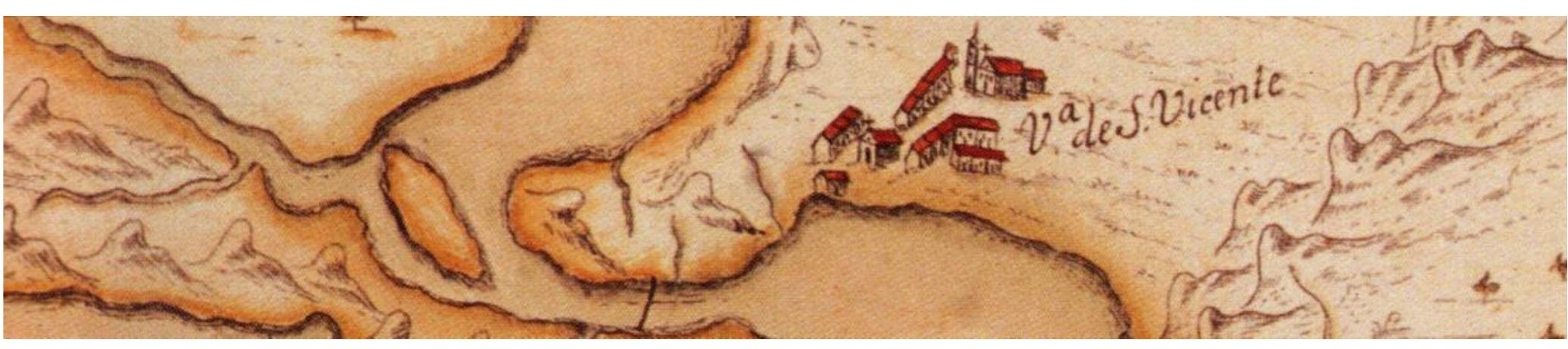

\section{3 "Sam Vicente"}

No Atlas de Kurstman (provavelmente elaborado entre setembro de 1502 e junho de 1504), já se encontram os nomes "Rio S. Vicente" e "Porto S. Vicente" devidamente assinalados (LUÍS, 1980, p. 66).

Não há documento que comprove ter sido S. Vicente feitoria régia como foram, ao menos, as de Cabo Frio e Igaraçu. Outras duas, no Rio de Janeiro e na baía de Todos os Santos, também são nebulosas quanto à comprovação de terem sido iniciativas da corte. Mas se não o foram, também exerceram sua função embrionária na imensidão costeira da colônia. A hipótese de S. Vicente ser tratada como feitoria pela historiografia justifica-se por haver em seu núcleo pré-afonsino uma casa "[...] feita de pedra com seus telhados, e uma torre para defesa [...]." (NEME, 1959, p. 23). O que não quer dizer que não poderia ter sido edificada por iniciativa do Bacharel e de seus "genros"... Duas expedições espanholas, de passagem pelo local, uma em 1528 com destino ao rio da Prata e outra em 1530, retornando da mesma região, deixam preciosos relatos das atividades e feições desse povoado. Da primeira, comandada por Diego Garcia, as informações são as seguintes:

E de aqui fuimos a tomar refresco en S. Vicente questa en 24 grados, e alli vive un Bachiller e unos yernos suyos mucho tiempo ha que ha 
bien 30 años, é alli estuvimos hasta 15 de Enero del año seguiente de 27 é aqui tomamos mucho refresco de carne e pescado e de las vituallas de la tierra para provision de nuestra nave é água é lena é todo lo que ovimos menester, é compre de un yerno deste Bachiller un vargantin que mucho servicio nos hizo; e mas el próprio se acordó con nosotros de ir por lengua al rio [da Prata], y este Bachiller con sus yernos y hicieron comigo una carta de fletamiento para las truxese en Espana con la nao grande ochocientos esclavos, é yo la hice con acuerdo de todos mis officiales é contadores é tesoreros (...) y esta uma gente alli con el Bachiller que comen carne umana y es mui buena gente amigos de los cristianos que se llaman Topies. (NEME, 1959, p. 23).

Na outra expedição, sob o comando de Sebastião Caboto, encontrava-se o cosmógrafo Alonso de Santa Cruz, que descreve:

Dentro do porto de S. Vicente há duas ilhas grandes, habitadas por índios e, na mais oriental [de Sto. Amaro], na parte ocidental, estivemos mais de mez. Na ilha ocidental têm os portugueses um povoado chamado 'S. Vicente' de dez ou doze casas, uma feita de pedra com seus telhados, e uma torre para defesa contra os índios em tempo de necessidade. Estão providos de coisas da terra, de galinhas de Espanha e de porcos, com muita abundância de hortaliça. Têm essas ilhas uma ilhota entre ambas de que se servem para criar porcos [provavelmente a atual ilha de Barnabé]. Há grandes pescarias de bons pescados (LUÍS, 1980, p. 66).

Eram os domínios litorâneos setentrionais do Bacharel até aportar aí, em 22 de janeiro de 1532, no aniversário de São Vicente (exatamente trinta anos após Américo Vespúcio), a esquadra de Martim Afonso de Souza. Chegava do sul depois da tentativa frustrada de adentrar o rio da Prata, sua principal missão. Os longos dezesseis meses de ancoragem na baixada santista deixarão à historiografia mais indagações do que certezas. Amigo de infância e portador da confiança de D. João III, parte de Lisboa munido de grandes poderes. A "Carta de Grandes Poderes ao Capitão-mor Martim Afonso de Souza", todavia, não faz referência à fundação de vilas. Nas três partes de que é composta, transparece mais a intenção descobridora do que colonizadora no "[...] envio à terra do Brasil e assim de todas as terras que ele dito Martim Afonso na dita terra achar e descobrir [...]." (RIBEIRO, 1993, p. 136). Responsável pela justiça, "[...] execução nos corpos e nas fazendas daqueles que o 
não quiserem cumprir [...]", dispunha de tabeliães e oficiais para registro de nomeações e doações de sesmarias (RIBEIRO, 1993, p. 137). A missão principal e urgente no preparo desta expedição foi alcançar, antes dos espanhóis, as terras do lendário "Rei Branco" nas paragens andinas, com supostas riquezas de ouro e prata. D. João III, ao saber que as viagens de Diego Garcia e Sebastião Caboto, citadas acima, estiveram próximas, mas não alcançaram as minas, apostou que se as descobrisse primeiro teria sua posse, mesmo ciente de estarem além da linha de Tordesilhas. O teor da Carta coaduna-se com essa intenção, afinal as terras do Brasil seguramente de domínio português, há muito já estavam descobertas... Outra missão, oportuna pela navegação rumo ao sul, foi dar combate aos franceses intrusos que invariavelmente freqüentavam nossa costa em busca do pau-brasil.

O "Diário da Navegação", texto elaborado a partir das anotações de viagem de Pero Lopes de Souza, irmão de Martim Afonso e um dos capitães da esquadra, tornou-se documento angular para o conhecimento dos passos da expedição. Mas deixou algumas armadilhas para a historiografia. Em exame de perícia paleográfica, comprovou-se ter sido escrito entre os anos de 1551 e 1575, quando já era falecido o autor das anotações, portanto foi redigido por terceiros (NEME, 1959, p. 82). É o suficiente para que se tenha cautela com suas expressões, a principal delas, de nosso interesse, a descrição:

Aqui neste porto de São Vicente varamos uma nau em terra. A todos nos pareceu tão bem esta terra, que o capitão I. determinou de a povoar, e deu a todos homens terras para fazerem fazendas; e fez uma vila na ilha de São Vicente... (NEME, 1959, p. 115, grifo nosso).

A controvérsia está na palavra vila, adotada talvez por desconhecimento de sua amplitude jurídica, ou porque na época da elaboração do texto as vilas estivessem afinal constituídas de direito, ou apenas como extensão do caráter exaltador da descrição (NEME, 1959, p. 76). Não só pelas comprovações 
documentais, mas pelo itinerário da viagem, não entendemos a expedição de Martim Afonso como um projeto colonizador para esta região. Trata-se de questão importante para a leitura da evolução das incipientes instalações urbanas. Ao que tudo indica, a estada em S. Vicente não estava nos planos do capitão-mor. Basta ver o seu roteiro: vem da Baía de Todos os Santos e adentra no Rio de Janeiro, onde se abastece de víveres para "2 anos". Daí segue ao sul, passa ao largo de S. Vicente e se abriga na ilha de Cananéia pelas condições meteorológicas desfavoráveis. Investiga o lagamar e encontra o Bacharel e Francisco Chaves; este se propõe a guiar uma expedição por terra às minas, para qual é nomeado Pero Lobo na chefia de oitenta homens. Combinam encontrar-se novamente ali após dez meses; a esquadra continua navegando em direção ao rio da Prata mas a nau capitânea naufraga com todos os víveres antes do estuário; "toma conselho" com os outros capitães e resolve voltar com os barcos restantes, aguardando apenas que Pero Lopes de Sousa adentre o rio da Prata com um bergantim para colocar dois padrões portugueses ao longo do rio; ancoram novamente em Cananéia, onde permanecem poucos dias, e partem enfim para S. Vicente, porto mais adequado para a longa permanência que lhes restava na espera do retorno da missão de Pero Lobo. A chegada desta esquadra em S. Vicente é, portanto, obra do inesperado. Decerto em clima de frustração, tanto pelo capitão como pelo aparato de tripulantes, (“[...] fidalgos, cavaleiros, escudeiros, gente de armas, pilotos, mestres, mareantes e todas as outras pessoas que na dita armada forem [...]", conforme "Carta de Grandes Poderes..."), comprometidos com as descobertas das minas. Em maio, poucos meses depois, Martim Afonso envia de retorno a Portugal um galeão e uma nau, comandados por Pero Lopes, seu irmão, com notícias do acontecido ao rei. Permanece apenas com uma nau e um bergantim. Boa parte dos viajantes, portanto, 
retorna ao reino. O capitão-mor passa a aguardar não só a expedição de Pero Lobo como também novas instruções de D.João III. Estas chegam depois de um ano, em janeiro de 1533, trazidas por João de Sousa. A carta do rei tece elogios ao amigo, mas o destitui de seus poderes, encerrando o projeto da expedição. Acena com os novos planos do reino para a colônia (Capitanias Hereditárias), nos quais irá reservar-Ihe "a melhor parte do Brasil". Estas notícias, muitos meses após os dez combinados, devem ter rompido os últimos fios de esperança no retorno de Pero Lobo "com 400 escravos carregados de prata e ouro", promessa do "língua" Francisco Chaves. Na verdade os oitenta homens da expedição (quarenta soldados e quarenta nativos), já tinham sido trucidados há vários meses nas imediações da foz do rio Iguaçu, alcançada pelo caminho do Peabiru. Em fins de maio de 1533 encerra-se a jornada de Martim Afonso: contrariado, levanta âncora de volta ao reino e nunca mais retorna a S. Vicente, sua futura Capitania. Em Portugal, semanas depois de chegar, sentirá o gosto amargo da derrota ao saber que enquanto aguardava a volta de Pero Lobo, em novembro de 1532, o cruel conquistador espanhol Francisco Pizzarro, descendo do norte pelo interior do continente com 153 homens e 127 cavalos, descobria e conquistava o rico império do Inca Atahualpa no Peru. A lenda do "Rei Branco" se confirmava. Este episódio deve ter contribuído para que Martim Afonso passasse uma borracha em sua memória ao relatar os feitos de sua expedição brasileira. Na "Brevíssima e Sumária Relação dos Serviços de Martim Afonso de Souza", que se diz escrita de próprio punho ao rei D. João III, relativos à costa do Brasil, tudo o que escreve é:

[...] por el-rey ter novas que no Brasil havia muitos franceses me mandou lá em uma armada, onde lhes tomei quatro naos, que todas se defenderam muito valentemente, e me feriram muita gente e assi nisto como no descobrimento de alguns rios, que me el-rei mandou descobrir, tardei perto de três anos, passando muitos trabalhos e muitas fomes, e muitas tormentas, até por derradeiro me dar uma tão 
grande, que se perdeu a nau em que eu ia, e escapei em uma tábua, e mandou-me el-rei vir de lá a cabo de três anos. (LUÍS, 1980, p. 60).

Nada sobre fundação de vilas, sobre assentamento de fidalgos, implantação de engenhos e outros feitos atribuídos pela historiografia. Mesmo depois de ter recebido a capitania vicentina através de duas cartas régias (6 de outubro de 1534 e 20 de janeiro de 1535), o dono das terras nunca mais olhou para elas. Ao contrário, seus escritos denotam desprezo pelas suas posses. Ao saber que o Conde da Castanheira (D. Antonio de Ataíde, seu primo) demonstrara interesse por parte dos seus domínios, escreveu-Ihe de Diu, na Índia: "Pero Lopes me escreveu que vossa senhoria queria um pedaço dessa terra do Brasil, que lá tenho; mande-a tomar toda ou a que quiser, que essa será para mim a maior mercê e a maior honra do mundo." (LUÍS, 1980, p. 58). Seu humor talvez revele o ônus que foram as Capitanias Hereditárias para os seus donatários. Foi um projeto leonino da coroa portuguesa que na contrapartida da doação de imensos territórios exigia investimento total por parte dos escolhidos. Recolheria os tributos sem nenhum dispêndio para isso. Mal colheu esses frutos; em poucos anos as capitanias inviabilizaram-se, levando a maioria dos donatários à ruína.

A expedição afonsina, mesmo não sendo parte de um plano reinol de colonização, como muitas vezes Ihe foi atribuída, deixará desdobramentos importantes e comprometedores para 0 seqüenciamento das instalações portuguesas, razão direta da presença dos viajantes que ficaram. Serão novos tempos para S. Vicente. Fala-se em 150 homens. Pelo evidente perfil exploratório das "terras a achar e descobrir", minas de ouro e prata, não havia mulheres na expedição. A longa permanência destas pessoas, 16 meses até o retorno de Martim Afonso ao reino, deve ter contribuído para a opção de alguns tripulantes se instalarem no local por mais tempo. A expectativa de novas descobertas nos 
horizontes de tantos sertões, além das lendárias terras peruanas, coadunava-se aos espíritos aventureiros. Munido destas atribuições, Martim Afonso doou sesmarias no litoral e no planalto contíguo, diretriz das ocupações rurais que foram se estabelecendo; não há registros, mas o povoado do Bacharel, pré-existente, provavelmente acolheu novas habitações, ainda precárias ou de melhor padrão, consolidando o mesmo sítio. Hoje entendemos que foi um período de transição, descomprometido com o futuro projeto colonial agrário exportador. Justifica-se a permanência na mesma povoação pelos critérios de escolha dos habitantes anteriores; foram suficientes, aos novos colonos, as mesmas condições ambientais protetivas ali encontradas: água doce, abrigo de ventos do sul, defesa de ataques corsários pela baixa profundidade de sua enseada e ainda, esta parte ocidental da ilha era oposta ao setor de penetração das investidas Tupinambá, vindas da frente oriental. Por ali foram se instalando, ao que tudo indica, seguindo a disposição preexistente.

No planalto, Martim Afonso nomeia João Ramalho "guarda-mor da borda do campo". Juntamente com Antonio Rodrigues são citados como "línguas da terra, e nela estantes de 15 a 20 anos" no registro da sesmaria que concede a seu lugartenente Pero de Góis. Outra sesmaria é concedida ao fidalgo Rui Pinto, ambas em outubro de 1532. Os colonos que ocuparam o planalto dispersaram-se pelo entorno dos campos de Piratininga, interagindo culturalmente com os Tupiniquins como já vimos.

Neste período, poucos anos após o retorno de Martim Afonso, a região vicentina vivenciará seu primeiro projeto colonial. Com a divisão do Brasil em Capitanias Hereditárias, D. João III escolhe, através de duas Cartas, o leal amigo que ali esteve como donatário dessa frente atlântica; Pero Lopes de Souza também 
recebe uma faixa territorial, menor que a do irmão, confusamente arbitrada entre a dele. Isto ocorre entre fins de 1534 e início de 1535. Antes destas nomeações Martim Afonso já estava em Goa, na Índia, onde fará carreira promissora até ser Vice-rei da Índia; mas deixa sua esposa com procuração para as providências necessárias: Dona Ana Pimentel será signatária das decisões relativas aos domínios vicentinos. Gonçalo Monteiro é o primeiro capitão-mor da Capitania, nomeado por ela. Decerto será ele o responsável pela ereção da Vila de São Vicente. A partir de agosto de 1537 documentos confiáveis mencionam S. Vicente como vila. Não há registro de seu foral; supõe-se que tenha sido elevada entre 1536 e 1537 sob as ordens de Monteiro, onde já se encontrava (NEME, 1959, p. 86). Nas atribuições da segunda carta régia de doação da capitania a Martim Afonso, de 20 de janeiro de 1535, diferentemente da "Carta de Grandes Poderes" da expedição, está explícito, conforme texto de Washington Luís:

3o - fazer vilas em todas as povoações, "as quais se chamarão vilas
e terão termo, jurisdição e liberdades e insígnias, segundo forma e
costumes do reino de Portugal, nas povoações, porém, que
estivessem ao longo da costa e dos rios navegáveis; nas outras
povoações pelo sertão e terra firme não poderia criar senão tendo
seis léguas de termo para cada uma delas, e depois destas criadas
não poderia fazer outras sem licença do rei" (LUís, 1980, p. 52).

As recomendações régias deixam transparecer a importância que se atribuía à fundação das vilas, inclusive com diretrizes para os enquadramentos territoriais.

Enquanto sede da Capitania, o novo status de Vila para o povoado de S. Vicente representará mais uma etapa de consolidação do seu núcleo germinal; embora sem registro, com certeza acrescentaram-se novas instalações para atender às exigências formais e ao novo contingente de colonos; ao que tudo indica, nada de arquitetura tão significativa, não restaram ruínas. É que em 1542, uma enorme ressaca, ou maremoto, de qualquer forma um incidente natural sem precedentes, 
destruiu suas edificações; foi reconstruída no sítio do atual centro histórico; talvez estivesse mais próxima da praia, em cota inferior, não sabemos, mas ao que tudo indica nos terrenos do entorno. Não foi seu primeiro revés. Em 1534, sofre violento ataque liderado pelo intrépido tenente espanhol Ruy Garcia Moschera que a saqueia e incendeia, ocasionando a morte de vários colonos deixados por Martim Afonso, "cerca de 100

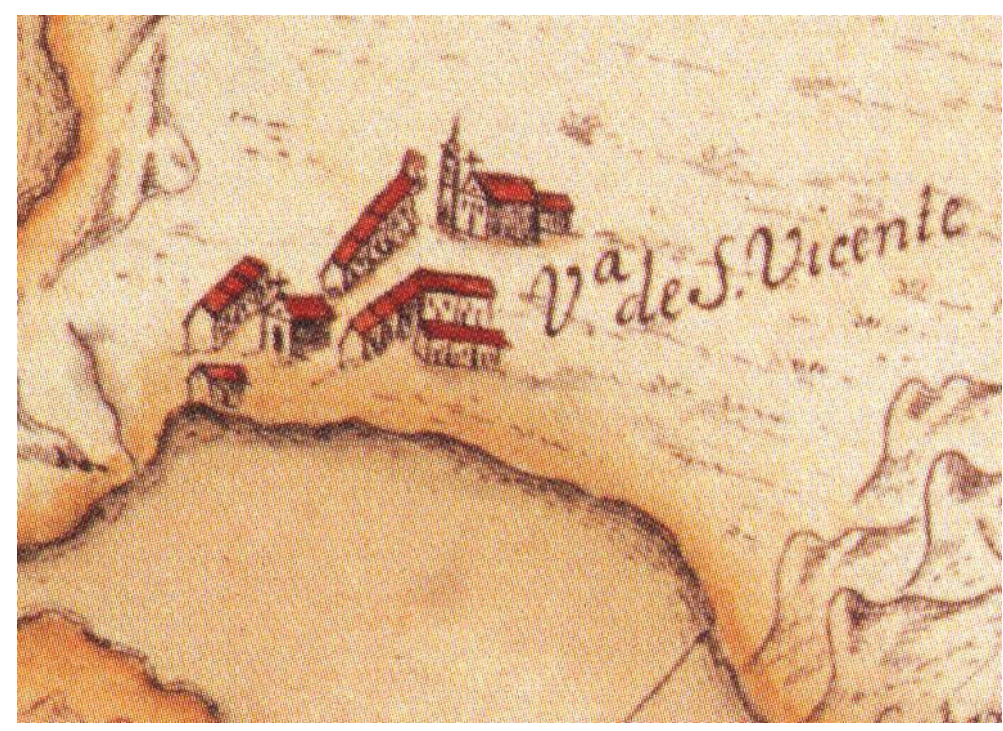

Figura 24. A persistência do sítio. Detalhe da "Planta da Barra da Villa de S.tos". Autor desconhecido, 1765/75. Fonte: REIS FILHO, 2001, p. 199.

pereceram no confronto". Foi o episódio conhecido com a "Guerra de Iguape". Reerguida pelos sobreviventes, retoma seu destino até o passo maior da criação da vila poucos anos depois. Portanto, duas adversidades arrasaram sua representação espacial em menos de dez anos. As vantagens das condições ambientais do sítio resistiram; se não foram questionadas nas duas reconstruções é porque atendiam às necessidades vivenciais dos habitantes.

Mesmo sua segunda reconstrução, enquanto vila e sede da capitania, não rompeu seus vínculos embrionários: persistiu seu traçado irregular. Conforme observação de Nestor Goulart Reis, "As plantas elaboradas nos primeiros anos do regime republicano [...] mostram aquelas três ou quatro quadras ao redor da matriz, com suas formas irregulares, que seriam as mesmas edificadas em meados do século XVI, após a destruição da vila de 1532, tragada por mudanças nas correntes marinhas." (REIS FILHO, sd, p. 559). 
Mas seu destino parecia de qualquer forma comprometido. Em resposta ao projeto colonial agrário-exportador, a incipiente produção açucareira da baixada vicentina demandava articulação eficaz com instalações portuárias. Os novos programas sociais colocaram em cheque as vantagens ambientais do sítio primitivo.

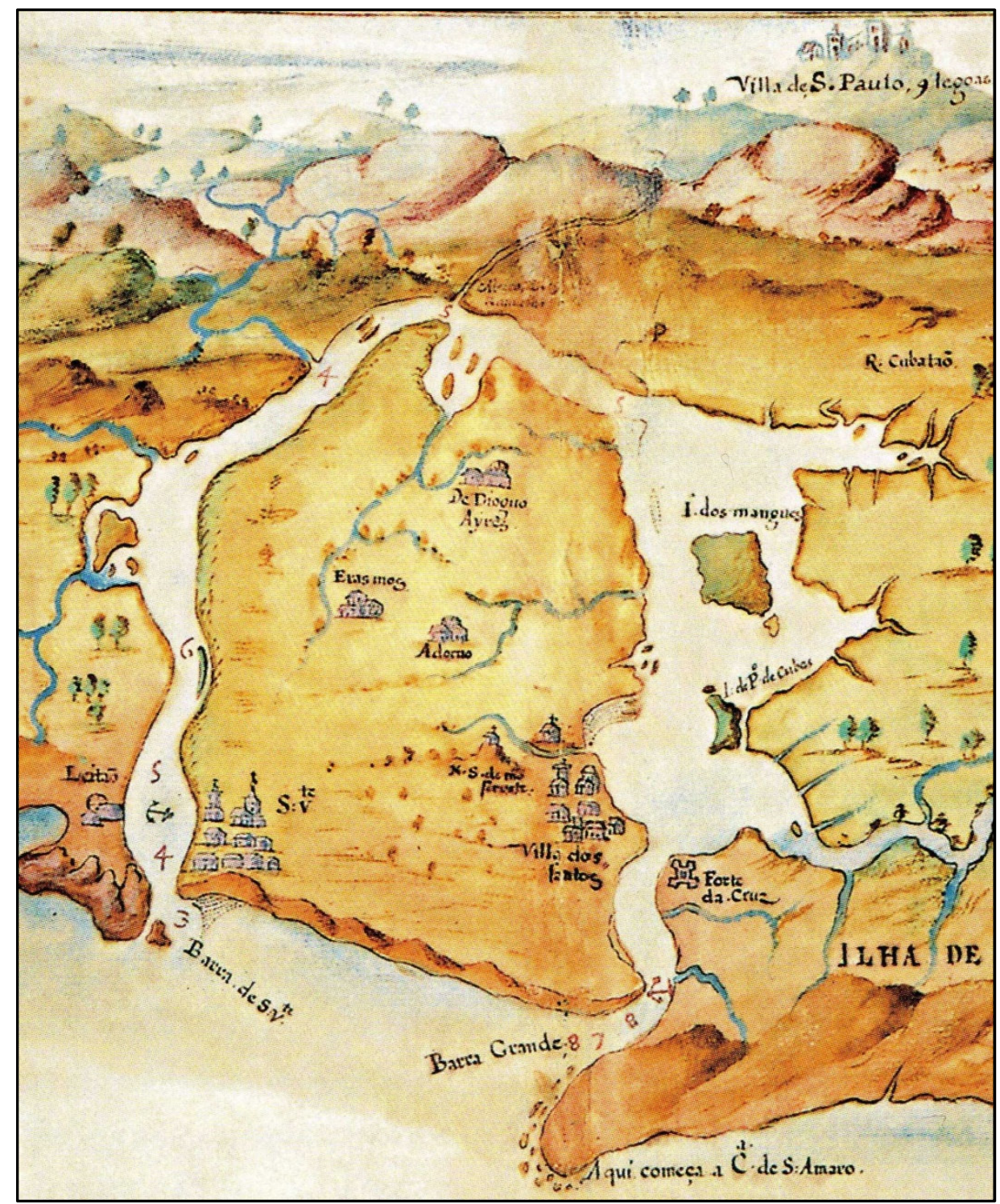

Figura 25. Portos e engenhos. Detalhe da carta "Capitan" de S. Vicente", aquarela de uma série da região vicentina, de João Teixeira Albernás I, de 1631. Notar a diferença de profundidade (braças) nas barras dos portos. Fonte: AB'SÁBER, 2005, p. 227.

Mesmo revitalizada pelo novo status jurisdicional, a Vila de S. Vicente estava dissociada do que passou a ser a principal referência espacial do projeto colonial: um porto mais adequado. Este, por seu significado econômico, será fundamental 
para a gênese de Santos, elevada a Vila em 19 de janeiro de 1545 . Não fossem os forais independentes, São Vicente, em relação ao novo núcleo, poderia enquadrarse na designação comum de "vila velha". A manutenção das duas vilas será questionada, anos depois, pelo próprio Governador Geral Tomé de Souza.

O nicho ecológico da primeira vila corresponde perfeitamente aos sítios de ocupação Tupi. Sabemos que a baixada vicentina era ocupada sazonalmente pelos Tupiniquins que habitavam Piratininga. Desciam pelos caminhos de ligação com o planalto, os "peabirus". No período dos contatos, a articulação utilizada era a Trilha Tupiniquim. É natural que escolhessem as barras do lagamar vicentino para seus acampamentos, onde a concentração dos cardumes de tainha facilitava seu apresamento. O sítio de São Vicente estava perfeitamente adequado. Protegido pelo "morro dos Barbosas" dos ventos do setor sul, implacáveis nesta época do ano, de sua encosta também vertia a água doce necessária. Conjugava estas variáveis ao remanso portuário do Tumiarú; este não era tão favorável como o de Santos por causa da pouca profundidade, mas atendia adequadamente o fluxo das embarcações menores, tão significativas no contexto das circulações do estuário. Um

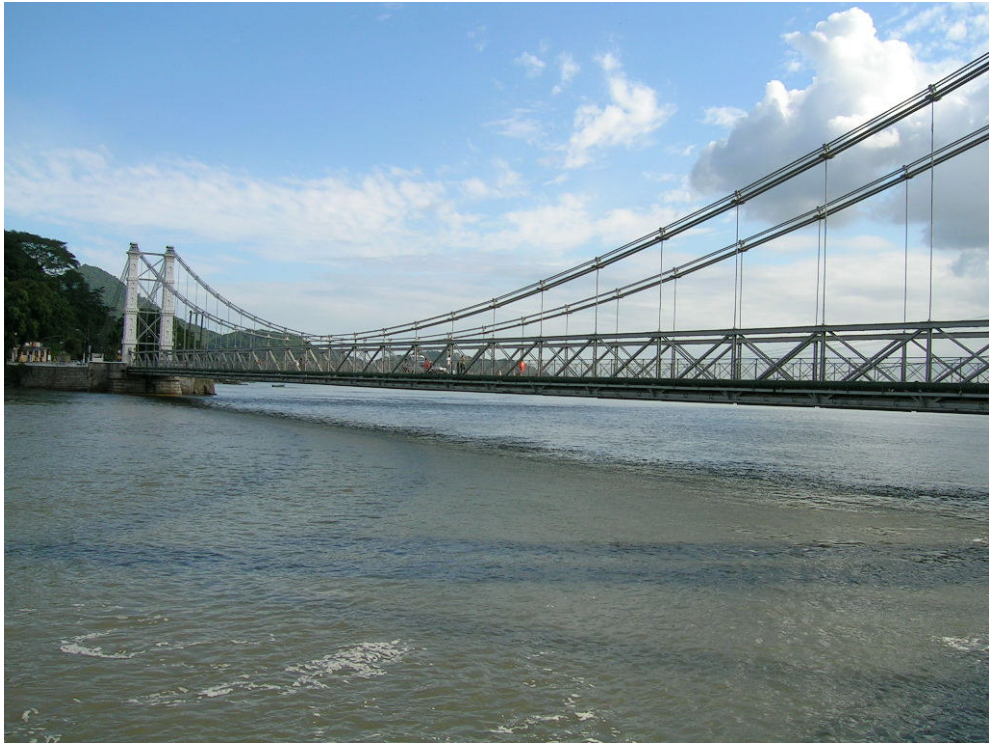

Figura 26. Bloqueio do Tumiarú. Foto do autor, 2005. fator sobrepunha sua vantagem em relação ao sítio de Santos: sua localidade era mais defensiva em relação aos assédios dos Tupinambá que adentravam principalmente pelo canal de Bertioga 


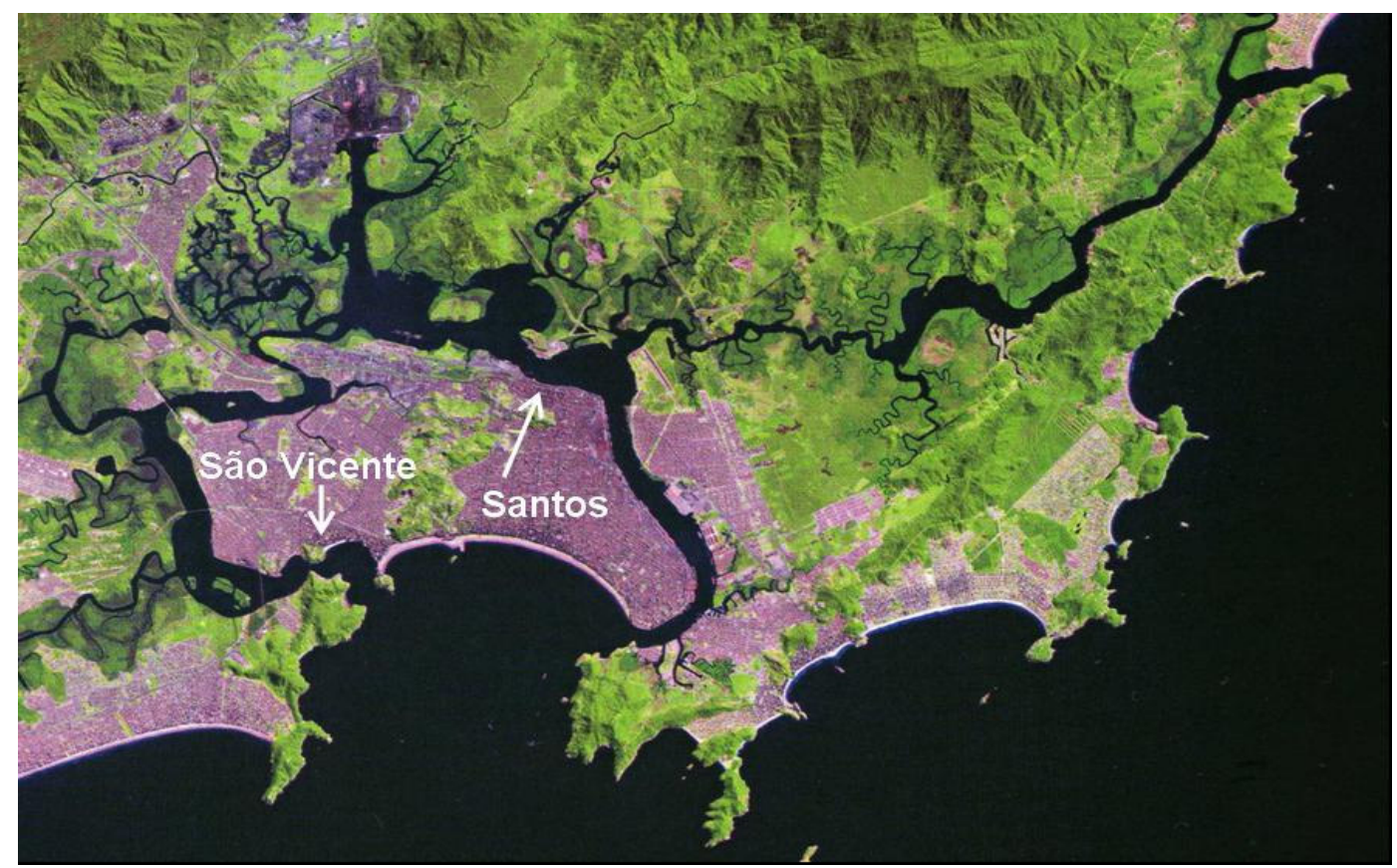

Figura 27. O Estuário. Fonte: AB'SÁBER, 2005, p. 219. Acrescentados textos do autor.

É notável que duas destruições em menos de dez anos e a fundação de Santos não bastaram para que seus povoadores desistissem. Foi o que ocorreu com a inadequada Santo André quando desdenhou os indicativos das ocupações

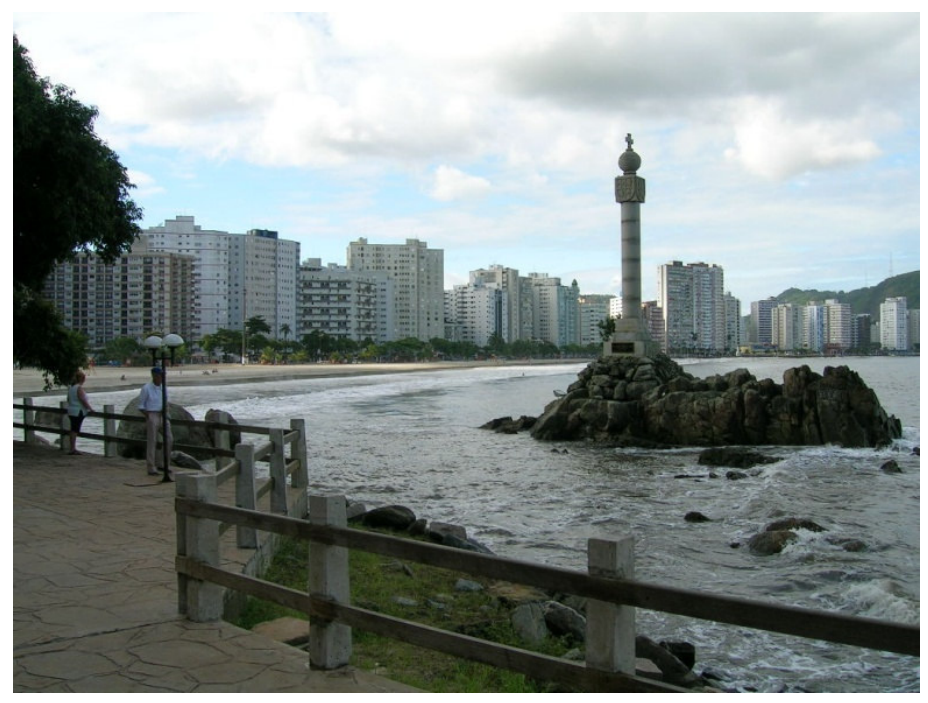

Figura 28. Memorial. Foto do autor, 2005. pregressas. Simbolicamente, as instalações edilícias de São Vicente talvez não tivessem a mesma importância que suas atribuições ambientais. Prevaleceu, portanto, o abrigo acolhedor, gradativamente seqüenciado até os dias de hoje. 


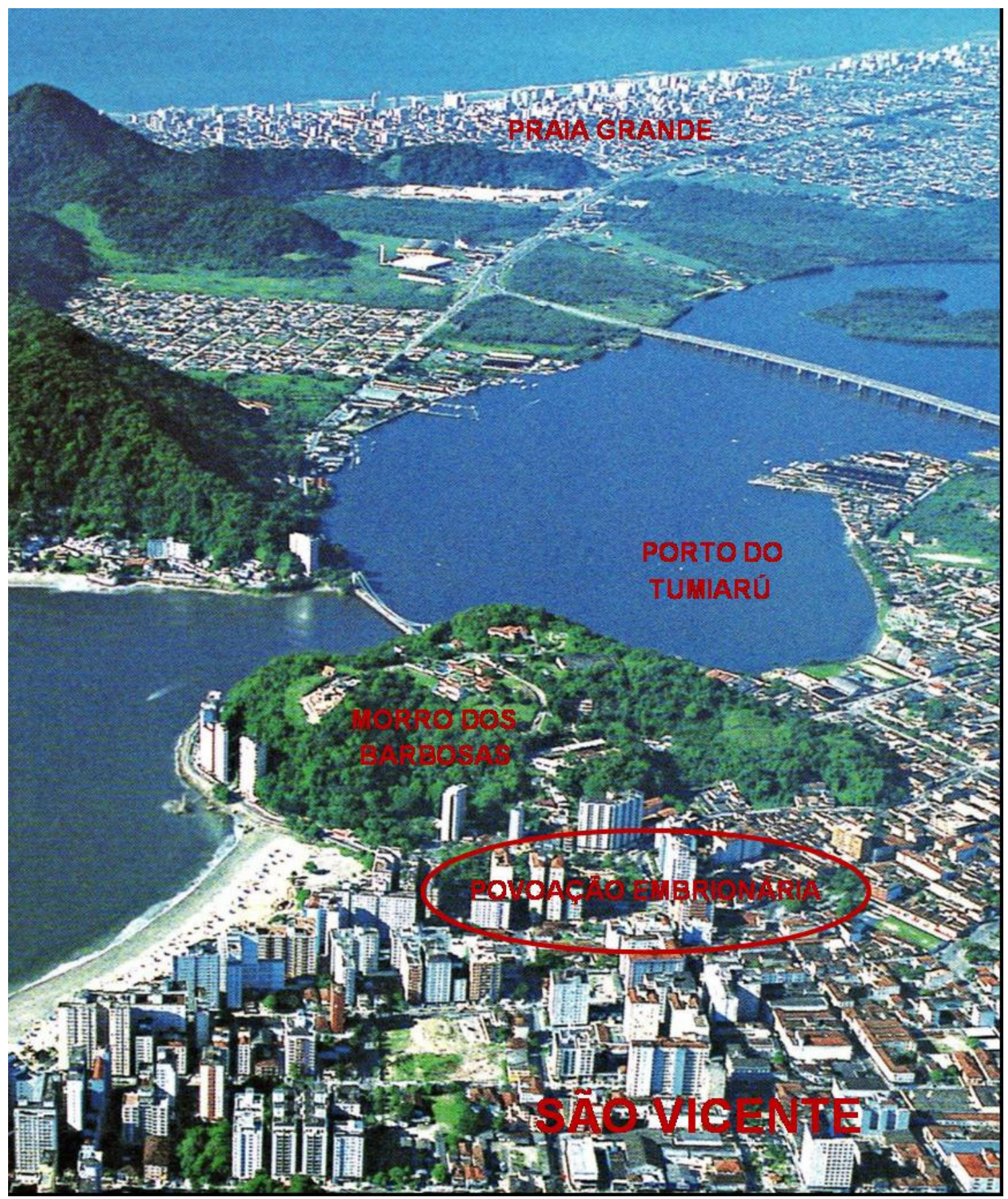

Figura 29. O sítio apropriado. Fonte: AB'SÁBER, 2005, p. 223. Acrescentados textos e sinalizações do autor. 


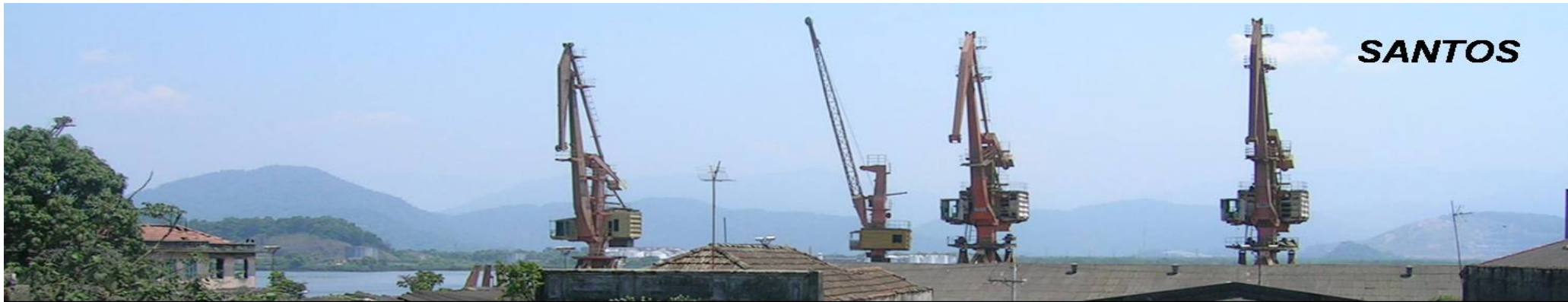

\section{4 "Villa de Santos"}

A natureza selou o destino da cidade portuária. Santos reservará a seu futuro intensa atividade, de portal do colonialismo agrário exportador da região vicentina ao mais significativo terminal mercantil do país. Confirmou-se o prognóstico de Tomé de Souza, nosso primeiro Governador Geral. Em carta ao rei D. João III, de 1 de junho de 1553, relata: "[...] a [vila] de Santos [...] tem o melhor porto que se pode ver, e todas as naus do mundo poderão estar nele com os proizes [amarras] dentro em terra." (LUÍS, 1980, p. 78). Seu entusiasmo não ocultou sua surpresa. A escolha

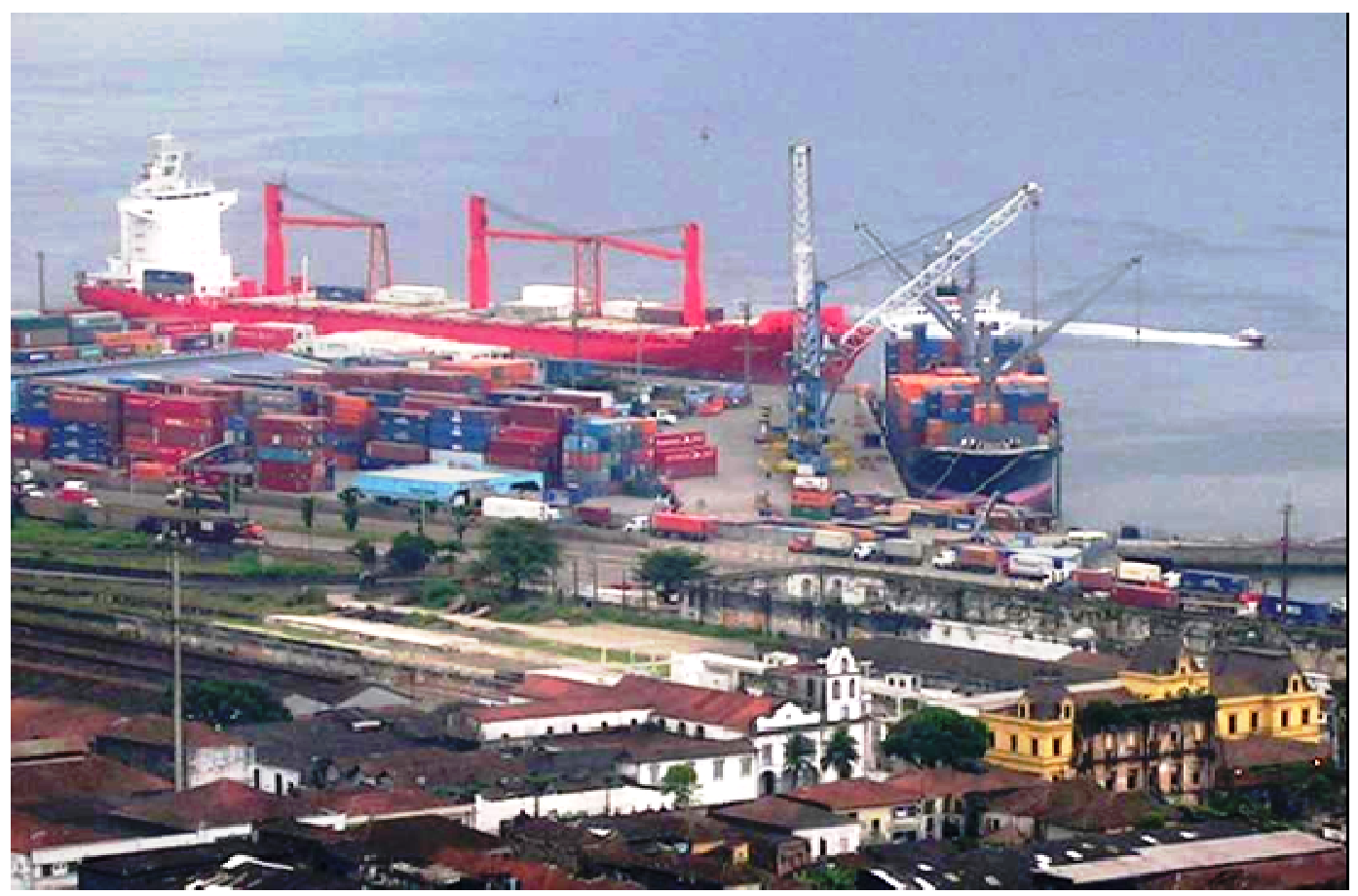

Figura 30. "Proízes em terra". O Convento de Santo Antonio e a estação da São Paulo Railway na era dos contêiners: séculos de convivências espaciais no bairro do Valongo. Vista do Monte Serrat. Foto do autor, 2005 
apropriada do sítio para o binômio porto-povoamento de Santos não foi deliberação da corte. Foi o máximo do esforço de alguns colonos dispostos a viabilizar os propósitos mercantilistas de sua presença na região, premidos pela necessidade de um escoadouro adequado para a incipiente produção dos primeiros engenhos de açúcar da colônia. O local, diametralmente oposto ao sítio da Vila de São Vicente, na mesma ilha, suplantava as condições portuárias inadequadas desse primeiro núcleo urbano, sede da capitania homônima, cujas instalações foram seqüenciadas a partir de uma povoação pré-afonsina. Tomé de Souza reitera na mesma carta: “[...] na qual ilha se fez outra vila que se chama Santos a qual se fez porque a de $S$. Vicente não tinha tão bom porto [...]. Santos precedeu-a em porto e em sítio, que são duas grandes qualidades [...]." (LUÍS, 1980, p. 78). Nessa viagem de 1553, já no fim do seu mandato, o Governador Geral também criou as vilas litorâneas de Bertioga e Conceição (Itanhaém), além da mencionada Santo André no planalto. A primeira e última visita do representante régio na região encontrou um incipiente e precário projeto colonial de ocupação. Suas providências, principalmente a criação de vilas e fortificações, representam um novo passo da presença portuguesa na Capitania de Martim Afonso. Mas não consolidam o quadro germinal da rede urbana desta frente atlântica, processo que, a nosso ver, só ocorrerá com a expulsão dos franceses, a fundação do Rio de Janeiro (1565) e o extermínio dos Tamoios no último quartel do século XVI. São episódios que asseguram o poder e o domínio lusitano na região.

O território da ilha de S. Vicente foi gradativamente ocupado por instalações rurais (figura 25, p. 101). Entre os colonos deixados por Martim Afonso estava José Adorno. Com seus irmãos, já havia se dedicado à indústria açucareira na ilha da Madeira. Outros colonos, se não vieram na expedição Afonsina, procederam nos 
anos seguintes, possivelmente estimulados pelas novas diretrizes colonizadoras. É o caso de João Gonçalves Meirinho, requerente de sesmaria em 1538, que se declara "[...] o primeiro homem que à dita Capitania veio [1537] com mulher casado, só com determinação de povoar [...]." (NEME, 1959, p. 131). Note-se que a proeza foi digna de registro! Vários colonos empreenderam esforços no novo mundo: Antonio Rodrigues, Estevão da Costa, Pero de Góis, Pascual Fernandes, Francisco Pinto, Rui Pinto, Domingos Pires, Pero Correia e, entre outros, Brás Cubas. Dois engenhos de açúcar, que se tem notícia, foram pioneiros: o dos irmãos Góis em 1533 e o dos irmãos Adorno em 1534. O principal, "engenho do Governador" ou dos Erasmos é do inicio da década seguinte (figura 25, p. 101). Essas instalações gradativas encontraram no interior da ilha os terrenos mais secos apropriados aos cultivos. Demandaram articulação de caminhos, da sede da vila às margens do canal de navegação a nordeste. Ali estavam as terras do "Enguaguaçu", onde "Nos primeiros anos, quando todos os povoadores lavraram nesta Ilha, onde queriam, Pascoal Fernandes Genovês e Domingos Pires fizeram sociedade, e ambos vieram situar-se em Enguaguaçu [...]". Frei Gaspar Madre de Deus informa também que: "Para sua particular serventia abriram os ditos sócios o caminho antigo de Santos para $S$. Vicente, o qual principiava na sua casa, continuava por uma ladeirinha, e passava por detrás do outeiro, onde hoje está o Mosteiro de S. Bento." (MADRE DE DEUS, 1975, p. 111). Pasquale Petrone comenta sobre essa articulação, delineadora do desenho urbano da futura vila, conforme veremos adiante:

O referido caminho deve ter sido dos mais antigos em tôda ilha, se forem excetuados os que aproveitariam as praias. Deve ter começado a definir-se para servir ao Engenho São Jorge dos Erasmos, ao mesmo tempo que era completado até Enguaguaçú. (PETRONE, 1965, p. 64). 


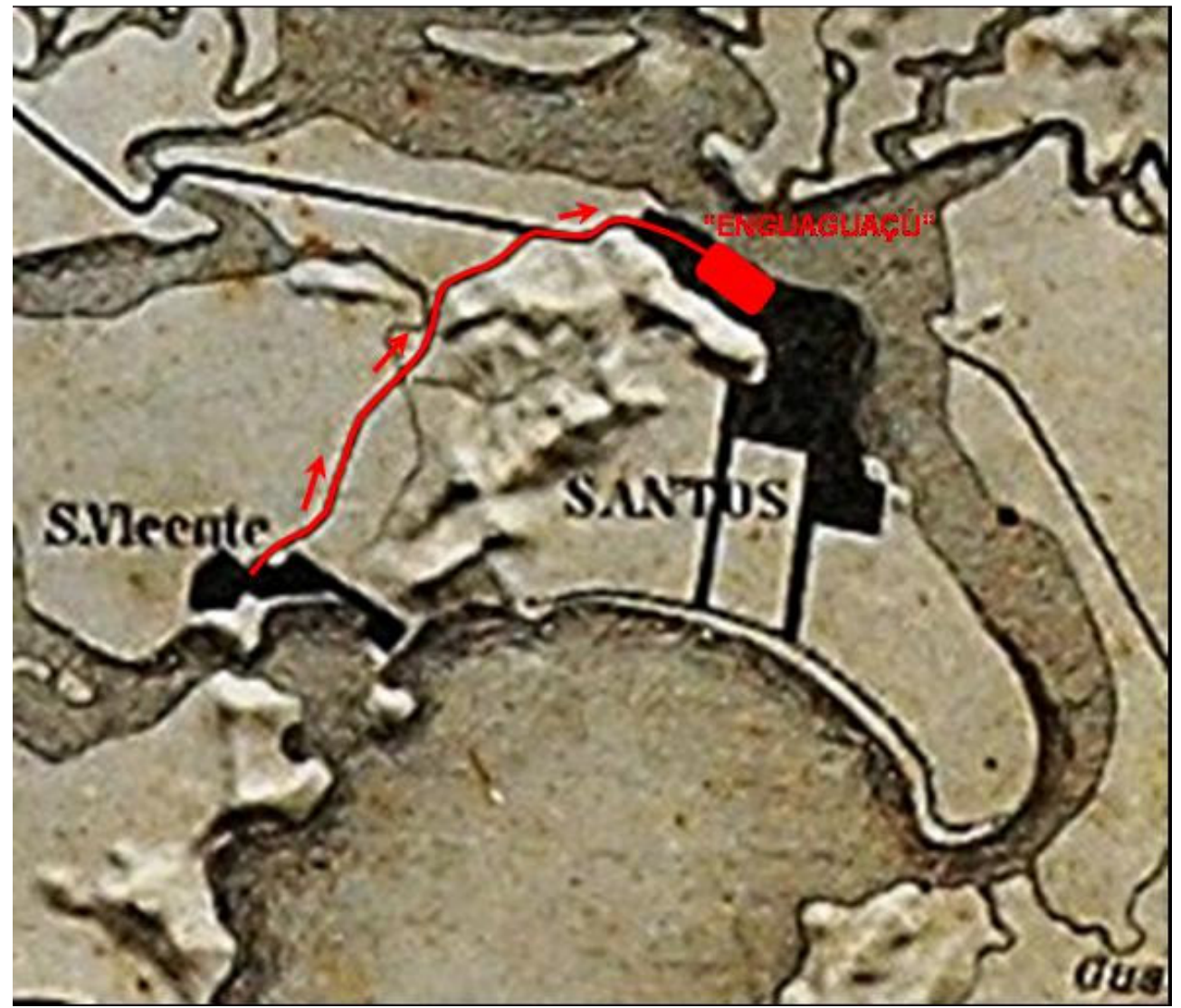

Figura 31.0 sítio ideal. A esplanada do binômio porto-povoação entre os morros e o canal portuário, alcançada pelo caminho. Det. da maquete do relevo "São Paulo and Santos". Fonte: Museu Paulista - autorização Of.459/05. Acrescentados texto e sinalização do autor.

Desta forma chegaram ao sítio ideal, que tanto agradará aos olhos do governador Tomé de Souza em 1553. Mas antes disso encantou também a outros olhares. O polêmico Brás Cubas, por concessão de 25 de setembro de 1536, feita por D. Ana Pimentel, esposa e procuradora de Martim Afonso, recebe as terras do "Jurubatuba", localizadas em frente ao Enguaguaçu, na outra margem do canal; incluíam também a atual ilha de Barnabé (figura 25, p. 101). Interessou-se pelo sítio que seguramente atravessava a caminho de seus domínios, pois “[...] adquiriu parte das terras dos proprietários do Enguaguaçu, ainda desocupadas, e que abrangiam o outerinho de Santa Catarina" (PETRONE, 1965, p. 45). Era um colono articulado com as gestões do reino e da igreja; envolveu-se sempre com a "administração 
portuguesa". Entre outras funções foi Provedor da Fazenda Real e Capitão-mor do donatário. Recebeu inúmeras sesmarias e também algumas demandas... Ainda, segundo Petrone, neste sítio,

[...] iria definir-se o povoado de Santos. Aí Brás Cubas teria erguido o primeiro monjolo que se conheceu no Brasil, assim como o primeiro Hospital de Misericórdia do país. [...] Área que já conhecia uma certa e antiga preferência para ancoragem das grandes embarcações, já antes da chegada de Martim Afonso, valorizou-se em seguida à sua ocupação por numerosos moradores, especialmente pela ação de Brás Cubas. Em 1534 já estaria esboçado um modesto núcleo, povoado de Enquaguaçu, com várias casas, roças de cana, engenhos e trapiches. As embarcações, ao invés de continuarem atracando junto à barra do rio de Santo Amaro, local isolado, passaram a dirigir-se ao ponto próximo do povoado embrionário. (PETRONE, 1965, p. 45).

Frei Gaspar Madre de Deus complementa:

Caminhou a passos largos a nova Povoação por nela fazerem casas todos os moradores do Rio da Bertioga; os de Terra firme mais chegada a Enguaguaçu; muitos da Ilha de Santo Amaro e vários da outra de $S$. Vicente, cujas fazendas estavam mais próximas à povoação do que à Vila. (MADRE DE DEUS, 1975, p. 114).

Nas motivações para implantação da nova vila, com certeza, estavam também os horizontes do planalto. A interação cultural com os Tupiniquins, fundamental para a permanência de tão poucos colonos nesta porção atlântica, permitiu a percepção, por parte dos europeus, dos fundamentos vivenciais indígenas. Simbolicamente as trilhas de serra acima nortearam a consolidação do colonialismo na capitania vicentina, resposta do contexto social onde a sociedade pregressa era dominante. A localidade de Santos, como a de São Vicente, com suas atribuições especiais no estuário da baixada, continuarão inexoravelmente articuladas com Piratininga. São domínios de um mesmo habitat.

O topônimo cubatão curiosamente repete-se em várias localidades da costa sul brasileira, inclusive em Cananéia. Designa locais onde as vias de circulação fluviais deparam com caminhos a percorrer. Sinal de mudança de meios, 
verdadeiros portos fluviais. Mais uma razão para a estratégica localização do sítio de Santos: a diretriz fluvial com a Piassaguera de Cima, no "pé-de-serra" onde iniciava a Trilha Tupiniquim. Outra razão: a articulação frontal do "rio de Bertioga". Este canal, palco de acirradas disputas entre as tribos Tupiniquins e Tupinambás pela posse dos pescados, era a principal via de circulação dos moradores que ocupavam suas extensas áreas adjacentes, do continente, da ilha de Sto. Amaro e do núcleo de Bertioga, localizado na barra nordeste (figura 27, p. 103).

Houve, decerto, uma convergência de vetores positivos para o sucesso do núcleo urbano. A condição portuária sem dúvida promove o empreendimento, tanto pela demanda mercantilista como pelas condições físicas adequadas (profundidade para os calados, facilidade de atracação em terrenos secos e abrigo natural de ventos e correntes marítimas). Na verdade, esta adequação estende-se ao longo de grande parte do "rio de S. Vicente", atual Canal de Santos, o que permitiria outra pontuação germinal. Nesse alinhamento, porém, um vetor de amplitude ambiental contribuiu para o local escolhido: a sua geomorfologia. O território da ilha de São Vicente é característico da faixa de planície costeira de solo arenoso confinada entre a Serra do Mar e a borda oceânica nessas latitudes. Em sua porção central, intercalam-se alguns maciços elevados que, diferenciando o relevo, alcançam o setor nordeste da ilha num alinhamento de morros paralelos à margem do canal, com o Monte Serrat sobrelevado. Entre estes morros e a borda da ilha, uma generosa esplanada de topografia plana acolhe o sítio histórico da cidade de Santos (figura 31, p. 108). Alguns componentes da sua paisagem, acrescidos a tantas variáveis, contribuem decisivamente para o processo de inserção do binômio portopovoado. A barreira natural dos morros, além de facilitar a oferta de pedras para as edificações, defende a área dos implacáveis ventos de sudoeste associados às 
frentes frias, principalmente no inverno. Mas sua maior virtude ambiental, sem dúvida, verte de suas encostas: nascentes de água doce. Sem elas não se fecharia o quadro ecológico possivelmente eleito como acampamento pré-colonial. Repete-se a paisagem das ocupações Tupi. Seus regatos de sopé de morro atravessam a esplanada e deságuam no canal, descomprometidos com a insalubridade marinha. Ao longo de toda frente portuária do rio de $S$. Vicente, não temos outro cenário pontual conjugado a tantos recursos.

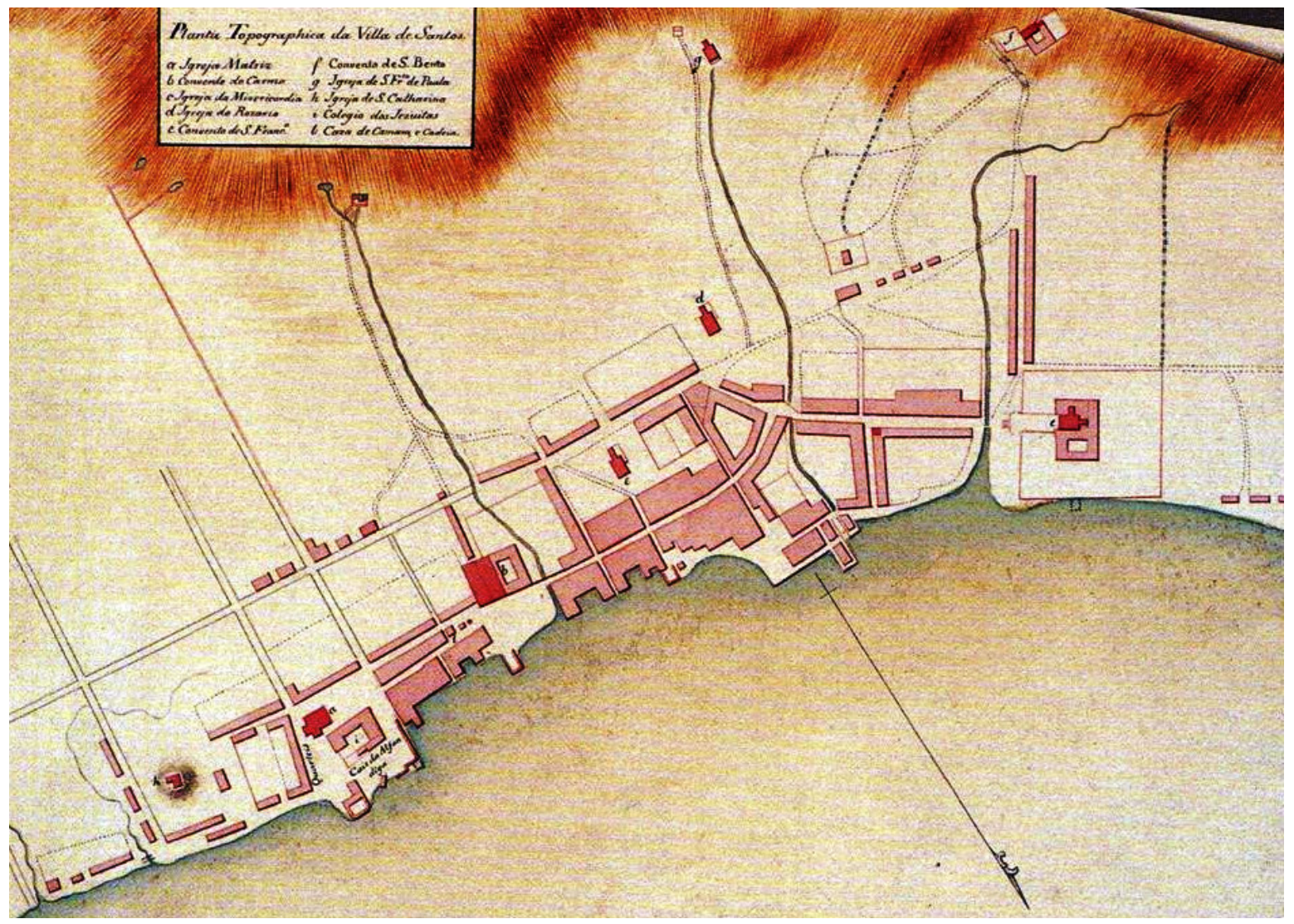

Figura 32. Água doce. A riqueza natural verte dos morros. Detalhe da "Planta Topographica da Villa de Santos", parte das "Cartas Corographicas e Hydrographicas...", de João da Costa Ferreira e seus colaboradores, 1815. Fonte: REIS FILHO, 2001, p. 201.

Recordando os tipos de embriões classificados por Aroldo de Azevedo e estudados por Murillo Marx, Santos pode enquadrar-se como Patrimônio Religioso (ver citação na página 25). Sobre um pequeno outeiro no setor leste da futura vila, limitando-a, será erguida uma capela sob invocação de Sta. Catarina, iniciativa de 
Luis Góis e esposa (1540). A proeminência da implantação no outeiro será, certamente nos seus primórdios, sua maior referência visual. Já na esplanada do sítio, em seu núcleo germinal, a instalação da Casa de Misericórdia foi uma das primeiras providências de Brás Cubas (1543). O foral da vila é de 1545.

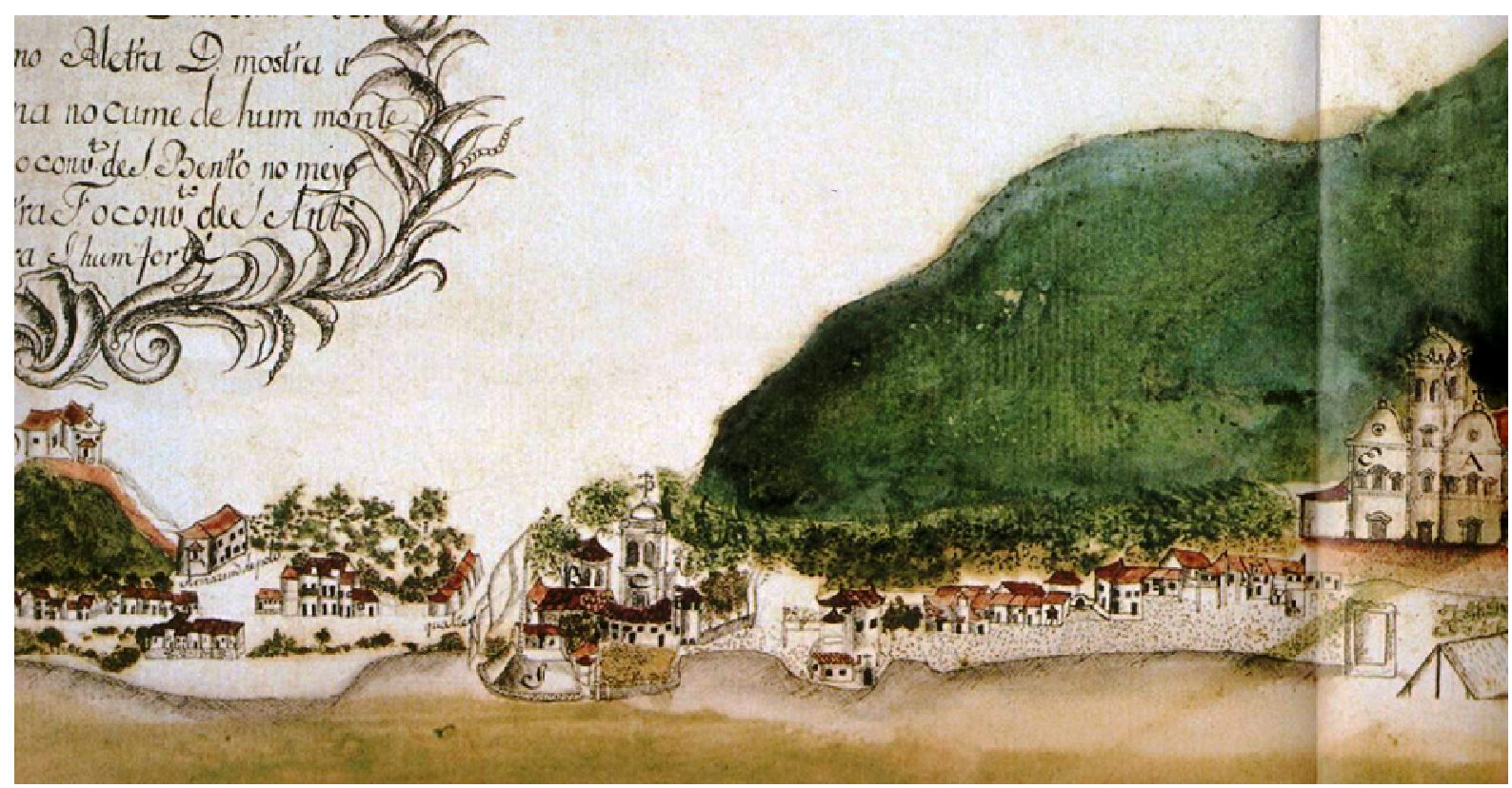

Figura 33. O núcleo no cenário ambiental. A imagem acima representa o núcleo germinal de Santos, do Outeiro de Santa Catarina (E) (1540) ao Carmo (D) (1599). No centro, a Matriz, o Convento Jesuíta e a defesa. É detalhe de um desenho intitulado "Villa e Praça de Stos" (1765/1775), de autor desconhecido. Fonte: REIS FILHO, 2001, p. 194.

Da praça da Matriz ao Carmo nota-se o alinhamento da "rua direita" 5 Sua extensão é o pioneiro caminho que, vindo de São Vicente, articulava as instalações agrárias da ilha homônima e chegava na área adjacente ao porto germinal (figura 31, p. 108). Seu traçado certamente delineou a direção para onde a Matriz foi voltada, com a valorização do seu frontão pelas perspectivas de aproximação da vila. Não podemos relevar a importância desse caminho, tanto pela polaridade com São Vicente, sede da Capitania, como pelo escoadouro da produção agrárioexportadora.

\footnotetext{
5 “[...] como imagem de síntese, a "Rua Direita" que corresponde ao arquétipo tido como original do urbanismo português, era a rua onde se encontravam os estabelecimentos os comerciantes mais importantes [...]. Nas cidades marítimas ou fluviais, a "Rua Direita" surgiu fundamentalmente em duas situações: ligando o principal acesso terrestre ao cais ou como via paralela à margem." (ROSSA, 1995, p. 251).
} 


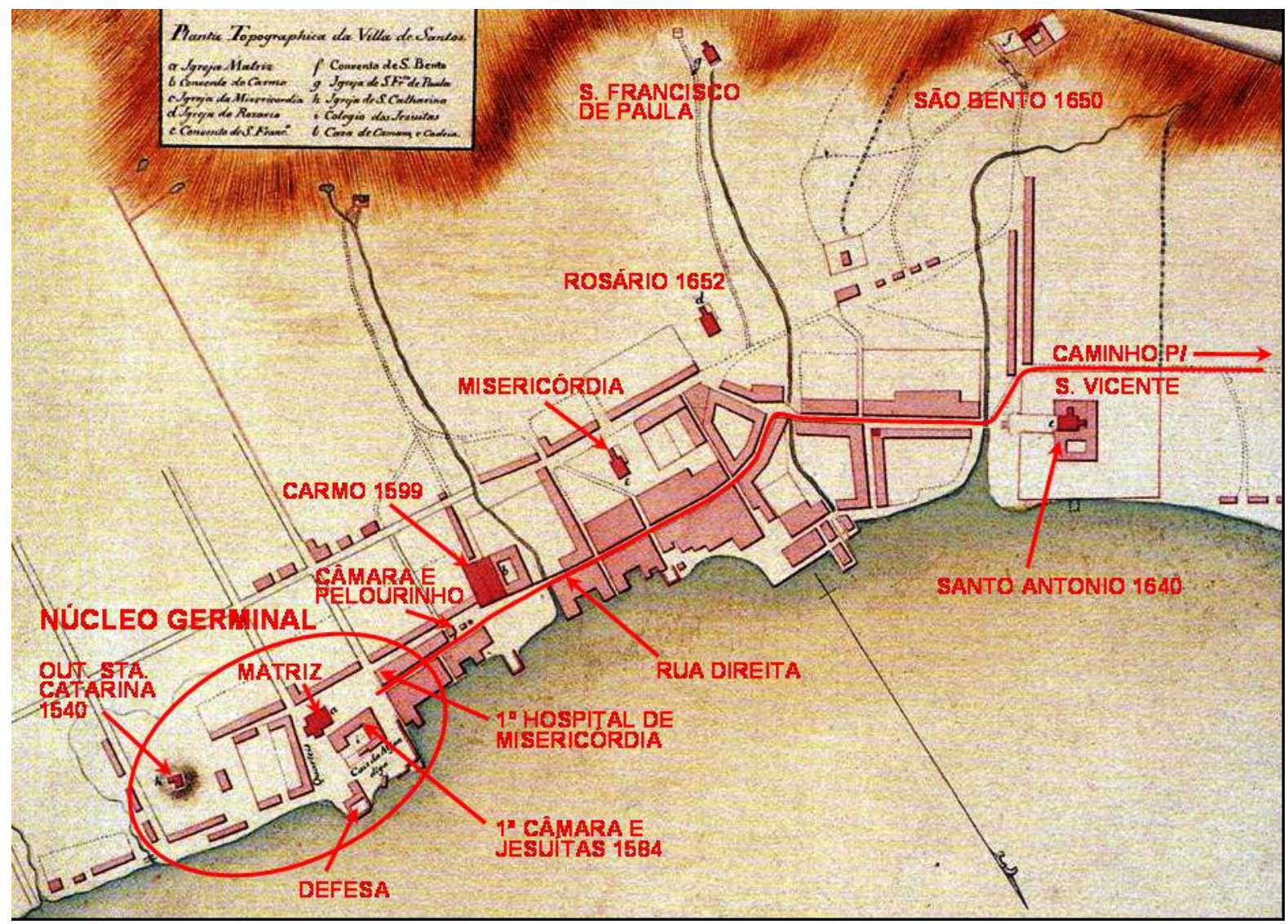

Figura 34. Nova era. A restauração da capitania em meados do XVIII consolida o núcleo portuário. A imagem do final daquele século mostra insinuações de expansão do tecido urbano. Detalhe da "Planta Topographica da Villa de Santos" mencionada. Fonte: REIS FILHO, 2001, p. 201. Acrescentados textos e sinalizações do autor.

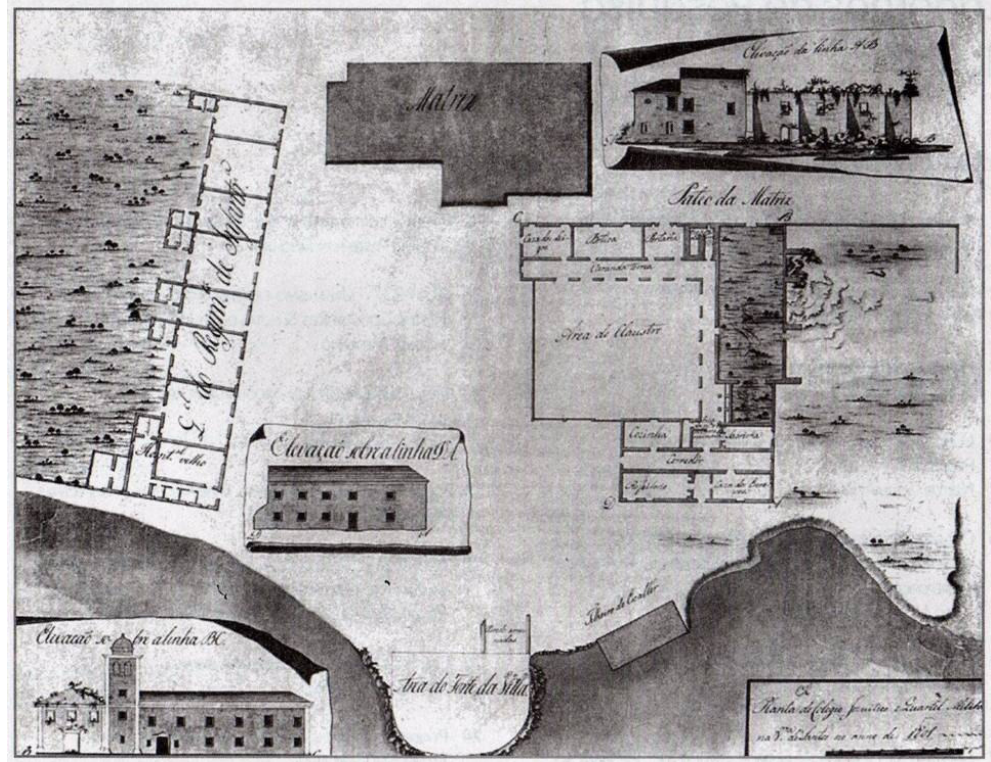

Figura 35. O embrião. Planta do Colégio Jesuíta de S. Miguel, antiga Câmara e Alfândega, ortogonal à implantação da Matriz. Aparece o "Quartel Militar" e a orla portuária, com a muralha de defesa pronunciada. Fonte: SMITH, 1998.
Com status de "rua direita" no intra-urbano, será vetor da expansão do núcleo, claramente seqüenciado na cronologia de implantação dos Conventos e Igrejas do Carmo e de Santo Antonio, este da Ordem dos Franciscanos. 


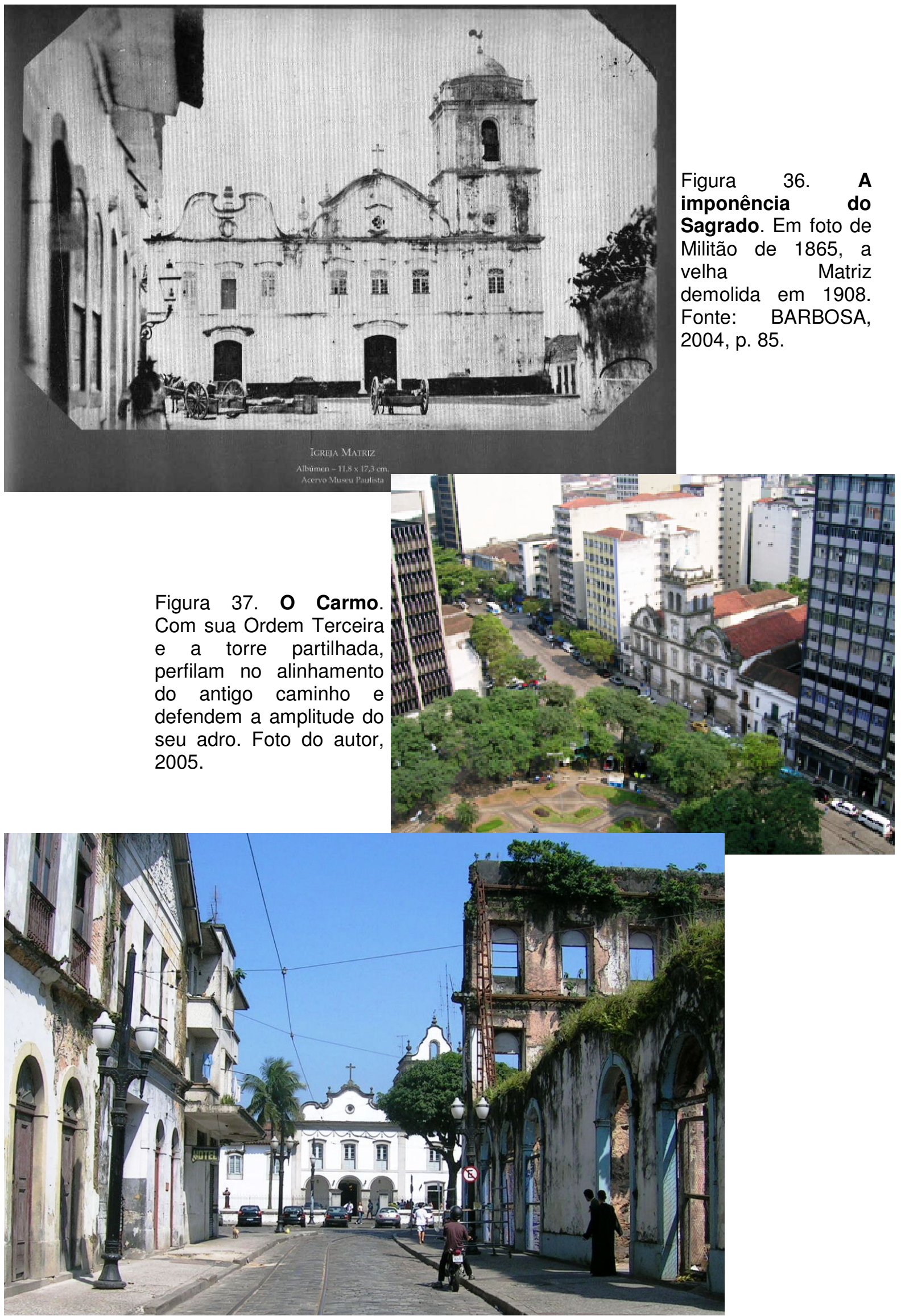

Figura 38. Igreja e Convento de Santo Antonio. Caminhos da expansão urbana. Foto do autor, 2005. 
Traduzidos em suas representações espaciais, os edifícios religiosos, independentes de suas escalas primárias, especialmente em sítios planos, irradiam sua ortogonalidade arquitetural no traçado das ruas, adros, largos ou futuras praças do seu entorno. Estas linhas, portanto, são balizadoras do desenho urbano em suas evoluções. Observamos nas vilas estudadas a reprodução desse modelo. Espelha a imponência da cultura religiosa fortemente atrelada ao Estado português no colonialismo. Um pouco mais de um século foi o tempo que Santos precisou para que as principais instalações religiosas correspondentes às suas ordens estivessem representadas na expansão do núcleo inicial de ocupação. Foi o período em que os

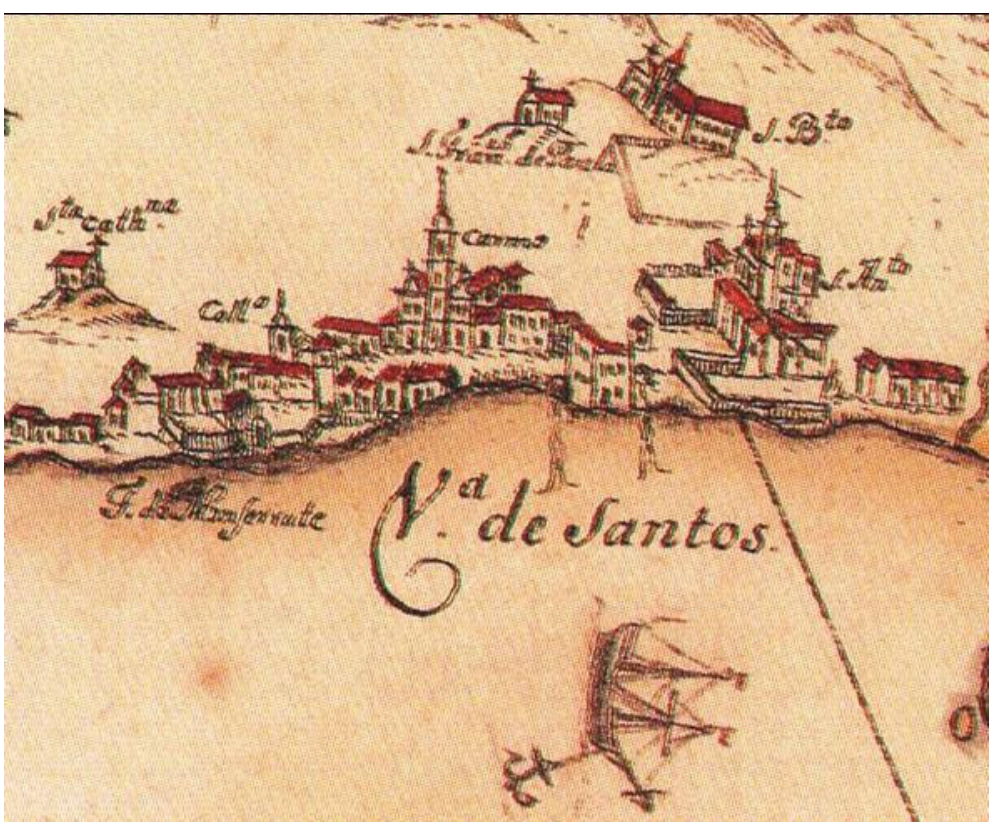
espaços de uso comum Figura 39. Os edifícios religiosos representam a vila. Detalhe da "Planta da Barra da Villa de S.tos". Autor necessariamente gravitavam desconhecido, 1765/75. Fonte: REIS FILHO, 2001, p.199.

os frontais dos edifícios religiosos, pelo forte caráter do sagrado na vida social. Com a passagem dos séculos, haverá uma gradativa laicização destes espaços públicos na diversificação dos usos, até a República dissociar formalmente a Igreja do Estado (MARX, 2003). Mas as referências espaciais destes "nós" ou "elementos marcantes" conceituais (LYNCH, 1990), até hoje permeiam o tecido urbano do centro histórico de Santos e de todas as cidades litorâneas com a mesma temporalidade.

Ao contextualizarmos a vivência cultural dos habitantes do passado na produção dos seus espaços, apropriamos o conceito de "topofilia", criado pelo 
geógrafo humanista Yi-fu Tuan (TUAN, 1980, p. 107). Trata-se, de forma simplista, do "elo afetivo entre as pessoas e os lugares", o que diz muito. As representações espaciais históricas espelham as percepções, os pensamentos, as atitudes e as emoções dos homens do passado. A religião envolvia todos segmentos culturais, da educação às festividades, da devoção espiritual aos compromissos materiais, das práticas religiosas aos controles civis. Não é de se estranhar a proeminência da

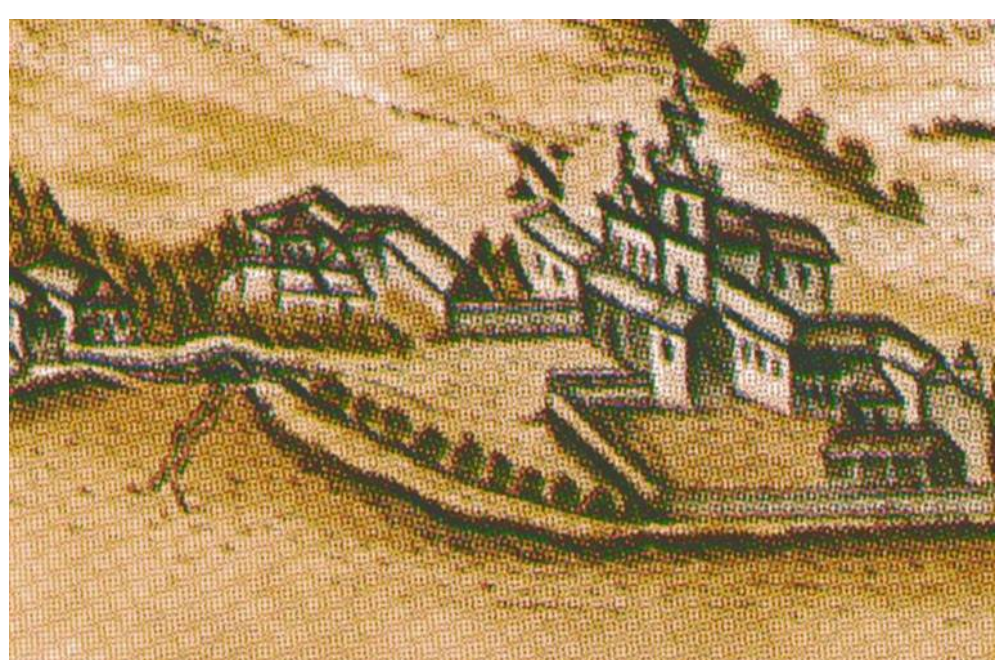

Figura 40. “Cosmo Vertical”. O sagrado na vivência social: primazia do superior na horizontalidade terrena. Detalhe do Convento de Santo Antonio no desenho "A Praça de Santos". Autor desconhecido, 1765/75. Fonte: REIS FILHO, 2001, p. 198. arquitetura religiosa em

relação ao espraiado de

casarios modestos, no

máximo assobradados, das

paisagens urbanas do

colonialismo vicentino. Os

espaços públicos, além da

circulação, eram os meios de comunicação, palco das informações e das

convivências, intensificadas nas festividades do calendário litúrgico. Os adros demandavam terrenos generosos, intrínsecos às igrejas. O volume edificado e seu vazio frontal figuram o que poderia ser entendido como um binário espacial: um módulo urbano composto da interação de dois espaços, diferenciados nas compleições e indissociáveis nas funções (figura 42, p. 118). Complementam-se na consagração do domínio espiritual; no interior introspectivo, o cerimonial, o diálogo com os Santos, com Deus; no exterior festivo, a extensão das amplitudes visuais de contemplação do sagrado, da cruz, dos frontões ornamentados, das torres, do "cosmo vertical" citado por Tuan (TUAN, 1980, p. 148). O sagrado vertical e o 
profano horizontal: atribuições geométricas próprias da Santos colonial, onde as torres das igrejas, baricentros de referência visual, destacadas do casario terreno, em busca do superior, ponteavam a paisagem urbana nas eqüidistâncias convenientes da gravitação de suas ordens religiosas. Simbolismo atrelado ao comunicacional: era de onde ecoavam os sinos. Sem barreiras, a linguagem de seus acordes codificados dissipava-se na extensão da vila portuária.

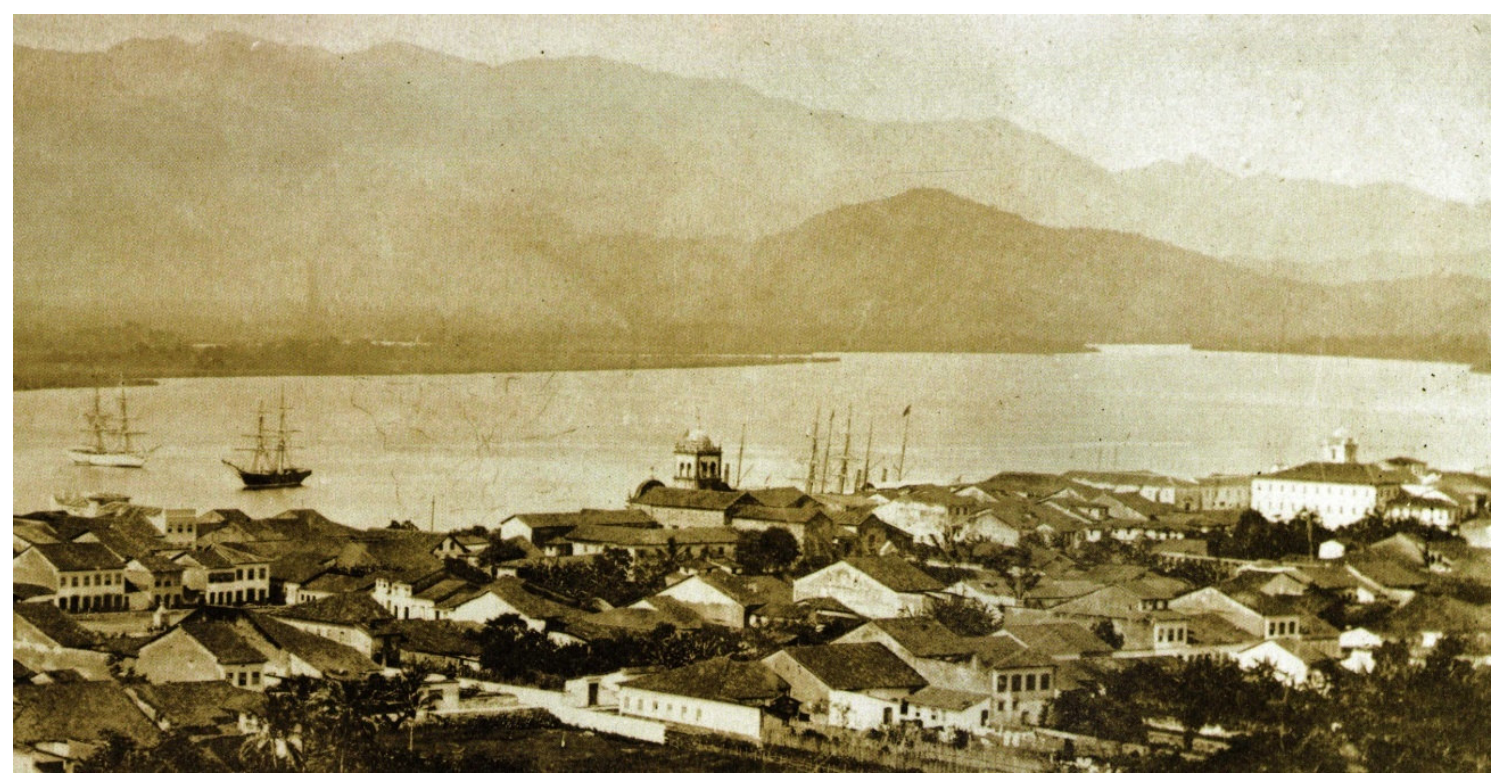

Figura 41. As torres. Baricentros comunicacionais da vila portuária. Detalhe de "Santos Vista do Monte Serrate", foto de Militão, 1865. Fonte: BARBOSA, 2004, p. 57.

A concepção de um módulo, mencionado acima, num povoado germinal conceituado como Patrimônio Religioso, seguramente comprometerá o desenho do futuro traçado urbano. A recíproca também é verdadeira quando se tratar de implantações decorrentes em tecidos já consolidados. Na inserção de novos módulos (atrelados a outras ordens religiosas em resposta à complexidade social evolutiva do núcleo), o tecido urbano, na trajetória de sua expansão, agenciará estes "elementos marcantes", adequando o prisma arquitetural na contigüidade dos seus alinhamentos. São nós articuladores do tecido urbano que transparecem nos traços de regularidade da planta de Santos. Em sítios de topografia plana será incomum se 
as faces prismáticas do edifício religioso não balizarem os alinhamentos das ruas adjacentes ou se não forem balizadas por elas.

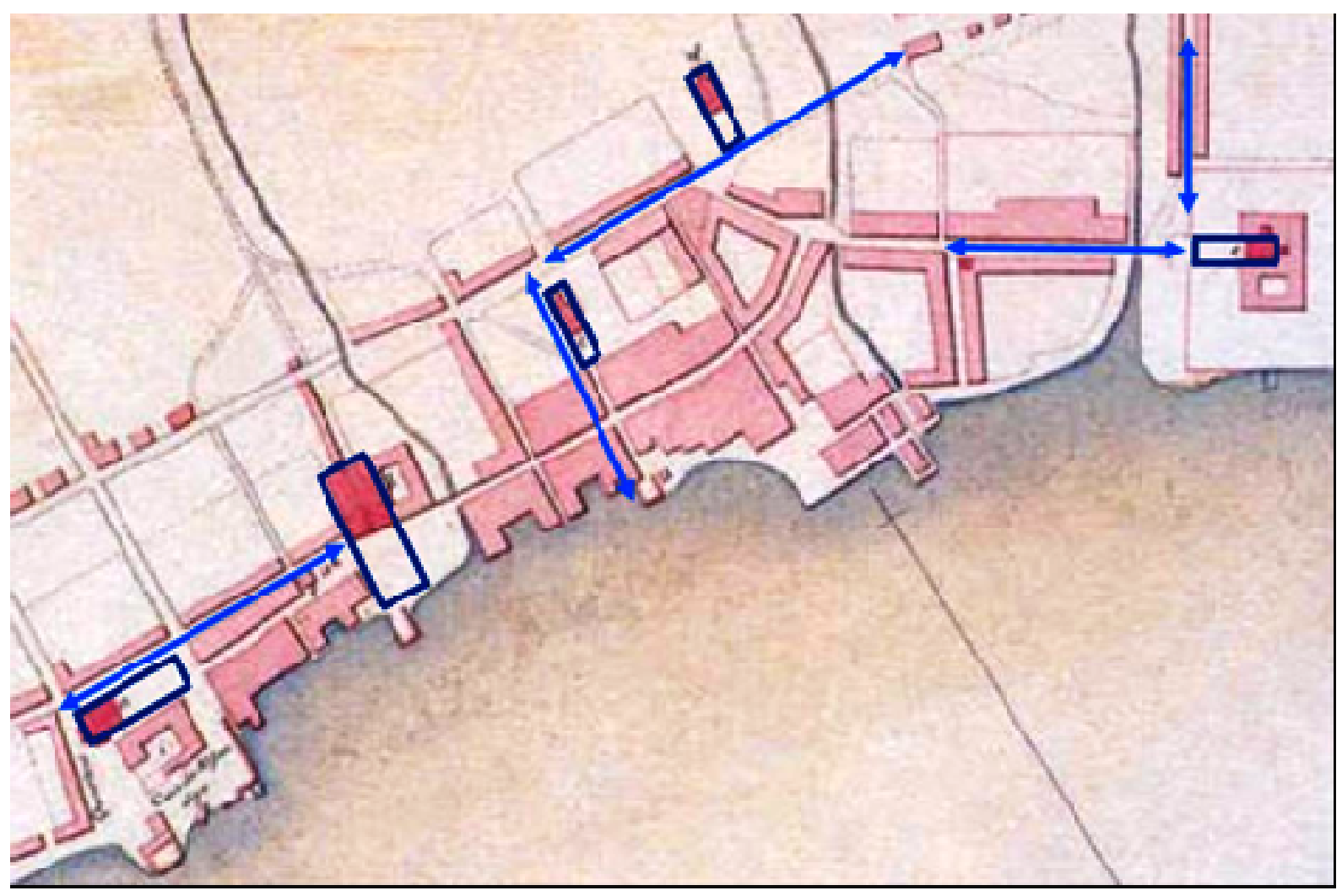

Figura 42. Os nós articuladores do tecido. Os edifícios religiosos, módulos espaciais implantados gradativamente, irradiam ortogonalidade no entorno. Detalhe da "Planta Topographica da Villa de Santos" mencionada. Fonte: REIS FILHO, 2001, p. 201. Acrescentadas sinalizações do autor.

O enquadramento da ermida, da capela, da igreja ou da futura matriz, no sítio e na paisagem, responde ao seu significado simbólico. Sua proeminência nos núcleos coloniais talvez deixe transparecer a enorme tarefa de se conduzir uma sociedade de raízes culturais tão diversificadas para as vertentes comuns do catolicismo e do poder central.

A “Planta Topographica da Villa de Santos", levantada pelo Engenheiro Militar João da Costa Ferreira e seus colaboradores, representa uma fase revitalizadora desse núcleo colonial (Figura 32, p. 111). São frutos da restauração da Capitania de São Paulo, promovidos a partir da segunda na metade do século XVIII pelo Governador D. Luís Antonio de Souza Botelho Mourão, o Morgado de Mateus, sob 
as ordens do Marquês de Pombal. A produção açucareira, principalmente no "quadrilátero" entre Sorocaba, Piracicaba, Mogi-Guaçu e Jundiaí, pode ter contribuído para isso (TOLEDO, 1981, p. 96). Sempre em sintonia com o planalto, a vila portuária responde com expansão urbana, claramente delineada na "Planta". Também como resposta ao desenvolvimento regional, a sofisticada Calçada do Lorena, inaugurada em 1792, obra dos mesmos engenheiros, interrompe o ciclo de 230 anos do sofrível Caminho do Padre José. (TOLEDO, 1981, p. 108).

Antes disso, a região vicentina viveu dois séculos e meio praticamente movida por sua sorte. O ciclo açucareiro pioneiro da baixada teve curta duração. A faixa litorânea, por seu clima, qualidade do solo e extensão, limitava naturalmente os horizontes produtivos. Outro fator relevante dificultou sua prosperidade: a longa distância dos centros consumidores. Pouca produção para a contra-corrente do fluxo natural das navegações. Essas dificuldades ecológicas e estratégicas foram suplantadas pela concentração do ciclo açucareiro no nordeste do Brasil. Os colonos vicentinos se interiorizaram, aproximando-se das diretrizes de ocupação pré-colonial. Baseados em Piratininga, promoveram incansáveis penetrações nos sertões em busca de minas e, principalmente, do apresamento de mão-de-obra indígena. Não iam sozinhos, arrastavam contingentes de índios já escravizados para os serviços e as guerras. Utilizavam as trilhas e os caminhos continentais pré-existentes. Foi um período de convivência forçada com quem detinha a sabedoria das vivências na terra $^{6}$. Conforme John Monteiro, os apresamentos visavam principalmente o suprimento de mão-de-obra local, ao contrário do recorrente na historiografia de que eram vendidos no Nordeste. Assim os colonos paulistas sedimentaram seus domínios, asseverando relativo isolamento regional. A produção de trigo no planalto

\footnotetext{
6 Falavam a mesma língua: o tupi. A "língua geral” de uso cotidiano, como forte traço a interação cultural, foi utilizada na sociedade mameluca até a primeira metade do século XVIII (HOLANDA, 1971, p. 93).
} 
paulistano no século XVII, principalmente das adjacências da Serra da Cantareira, era transportada para Santos nas costas dos escravos (MONTEIRO, 1994). Compreende-se a longevidade do dificultoso Caminho do Padre José pela disponibilidade de mão-de-obra indígena.

Os missionários jesuítas defenderam seus catecúmenos como entenderam, concentrando-os nos "aldeamentos paulistas" (PETRONE, 1995); reivindicaram com sucesso medidas protetivas da corte que não intimidaram os interesses bandeiristas. Foi um jogo de forças onde o índio sempre perdeu. Foram desintegrados dos cenários seculares de sua vivência, especialmente pelas guerras e doenças dos brancos: "Até o fim do século, grande parte do território antes ocupado pelos Tupiniquim e Guaianá encontrava-se seguramente em mãos dos conquistadores." (MONTEIRO, 1994, p. 56). Mas ficaram fortemente incorporados na nova sociedade constituída após o encontro cultural com os europeus que aqui aportaram. 


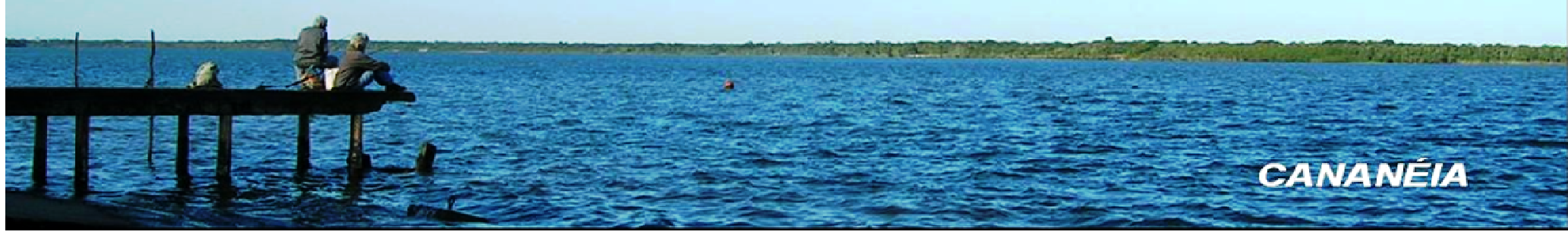

\section{5 "São João Batista de Cananéia"}

Em 27 de janeiro, dando seqüência à navegação costeira rumo ao sul, a expedição reconhecedora da costa de Gonçalo Coelho, tendo a bordo Américo Vespúcio, encontra abrigo na porção meridional de uma extensa e baixa ilha adjacente à costa que terá o nome de Ilha de Cananéia. Foge à regra litúrgica por motivo desconhecido ou por não ter sido batizada nesta ocasião. Será a última localidade da costa brasileira observada por aquela esquadra, que ali ficou "fazendo aguada", até 15 de fevereiro de 1502. A expedição retorna a Lisboa descrevendo um grande arco pelo Atlântico Sul, ao sabor dos ventos e das correntes, antes de alinharem as proas para o hemisfério Norte. Provavelmente, com pressuposta intenção, foi abandonado ali por Gonçalo Coelho um dos mais enigmáticos degredados da nossa história: Cosme Fernandes, conhecido como o Bacharel de Cananéia. A principal fonte primária sobre as origens de sua presença na região é a narrativa citada na página 80 sobre São Vicente: "[...] e alli vive un Bachiller e unos yernos suyos mucho tiempo ha que ha bien 30 años [...]". Como a expedição do espanhol Diego Garcia é de 1528, aceita-se que chegou com Gonçalo Coelho. O mais significativo sobre o personagem é sua atividade prestadora de serviços. Os relatos das duas expedições espanholas e da façanha de Martim Afonso não deixam 
dúvida de que o astuto Bachare/ estabelecera instalações de apoio às navegações do Atlântico meridional. Entre criação de "galinhas de Espanha e de porcos" e fabricação de "un vargantin que mucho servicio nos hizo", notabiliza-se nas povoações germinais de Maratayama (Cananéia), Icapara (Iguape) e São Vicente.

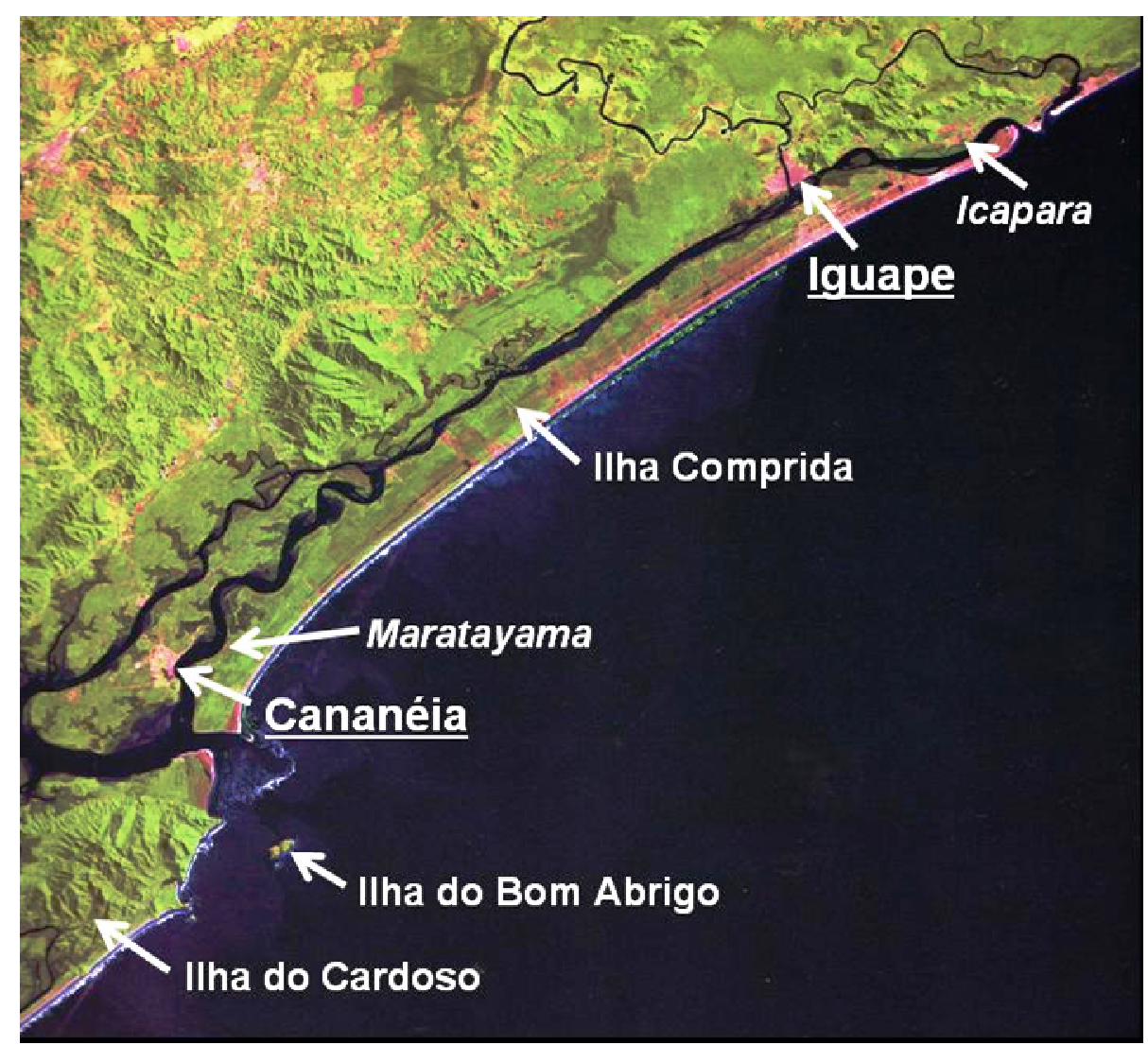

Figura 43. O lagamar. As vilas e respectivos núcleos germinais nos atrativos estuários. Fonte: AB'SÁBER, 2005, p. 235. Acrescentados textos e sinalizações do autor.

Outros europeus de mesma sorte ou náufragos, como no caso de um grupo de castelhanos acidentados na latitude de São Sebastião, agregaram-se nestes redutos como seus "vernos" (genros). Evidentemente eram vivências de interação cultural com a sociedade indígena, como ocorria no planalto entre João Ramalho e outros portugueses com os Tupiniquins. Mas o nosso Bacharel, ao que tudo indica foi pioneiro. A população de subtradição Tupi que habitava o baixo rio Ribeira de Iguape foi receptiva aos contatos e às permanências destes proto-colonos, "línguasda-terra" (ver última citação da página 53). Neste quadro setorial insinua-se 
claramente um desdobramento significativo dos contatos. Entre os serviços prestados por Cosme Fernandes documenta-se o apresamento indígena para o comercio escravagista. As localidades do litoral Sul eram especialmente estratégicas para esta atividade: articulavam-se diretamente com o Peabiru ${ }^{7}$ através das vertentes do rio Ribeira, por onde se alcançava a região dos inimigos Carijós

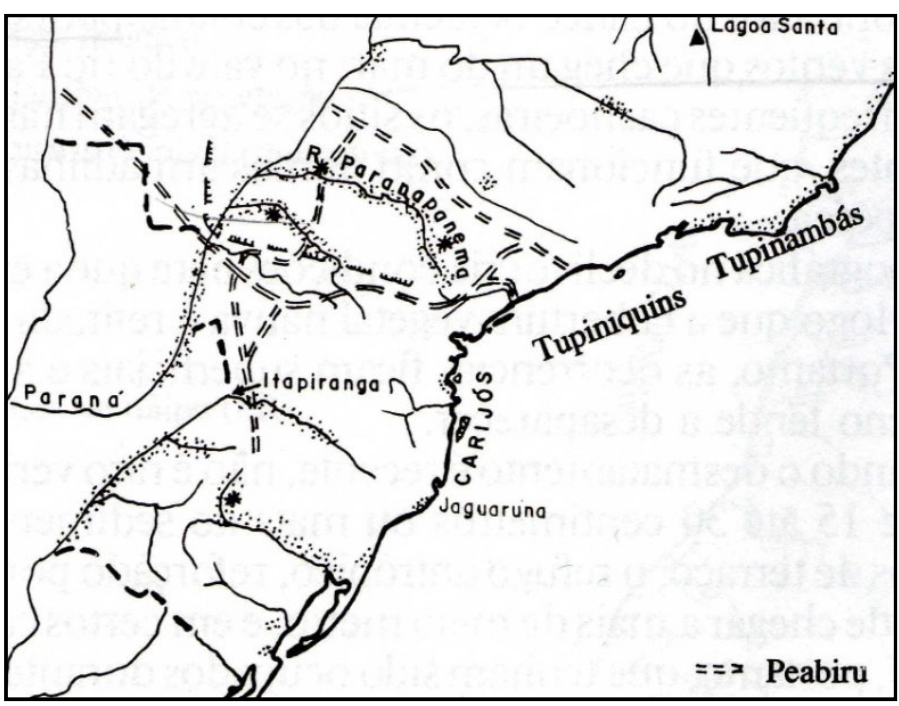

Figura 44. O Peabiru. Fonte: PROUS, 1992, p.375

(Guaranis). A manipulação da animosidade secular intertribal iniciada pelos conviventes mercadores, com interesses estranhos às antigas vivências, contribuirá decisivamente para a desestruturação das culturas pregressas não só dessa região, mas de toda a Colônia. A prática disseminou-se no século XVII fomentada principalmente no bandeirantismo paulista (MONTEIRO, 1994), mesmo contrariando as posturas jurídicas da Corte (PETRONE, 1995).

Uma intrigante conjunção de fatores encadeia-se nessa região. O mesmo destino da discutível "zona de fronteira" na região será superposto pela partilha do Novo Mundo entre portugueses e espanhóis, jurisdicionada no Tratado de Tordesilhas. Cananéia torna-se razoavelmente aceita entre os ibéricos como marco sul da linha imaginária que dividia o continente. Talvez a presença portuguesa pioneira tenha assegurado isso, valendo a "pressuposta intenção" de Gonçalo

\footnotetext{
7 "Mais recentemente arqueólogos encontraram vestígios de uma ramificação do mais famoso desses caminhos, o Peabiru dos cronistas, que ia justamente de Cananéia até o local onde fora fundada a cidade de Assunção. A via principal subia o vale do Ribeira até a nascente, cruzando depois o Paraná, onde atravessava as águas do Tibagi e do Ivaí, descendo depois o vale do Piquiri até o Paraná, saindo então do território brasileiro". (PROUS, 1992, p.374).
} 
Coelho no desembarque de Cosme Fernandes nestas paragens. Veremos que no episódio da "Guerra de lguape" essa posse portuguesa foi contestada, da mesma forma que colonos de Castela estabeleceram a povoação de São Francisco do Sul, ao norte de ilha de Santa Catarina em meados do século XVI, ao que se saiba sem contestação imediata dos portugueses.

A relevância ambiental do sistema lagunar estuarino de Cananéia-Iguape sempre atraiu assentamentos humanos. Algumas particularidades ambientais são significativas para a compreensão do processo germinal de ocupação, pelos europeus, deste setor meridional da região vicentina. A ilha de Cananéia, atual Ilha Comprida, limita com sua borda continental um extenso lagamar (ambiente marinho e fluvial do limite costeiro - Figura 43, p. 122). Dois estuários de drenagem com o mar, nas pontas norte e sul da ilha, equilibram os fluxos e refluxos das marés. Suas "barras" simbolizam portais da paisagem de águas interiores, celeiro de rica diversidade ambiental. É natural que, nos remansos abrigados desses canais, os sítios secos, com disponibilidade de água doce, fossem escolhidos para os assentamentos. Melhor ainda se gravitassem junto às "barras", tanto pela oferta de pescados, especialmente dos cardumes sazonais de tainha, como pela circulação marítima. Esse último componente de escolha ambiental decerto foi o que mais interessou aos ádvenas mercadores. As localidades consolidam-se como portos naturais estratégicos do alinhamento costeiro, vitais para suas atividades. Esta superposição de programas será reproduzida em todas as vilas de nossa frente atlântica.

No I Seminário “Cananéia Tem História”, realizado nessa cidade em setembro de 2005, a arqueóloga Maria Cristina Scatamacchia, respondendo à questão "em quais sítios de núcleos urbanos históricos da região foram identificados sinais da 
preexistência de ocupações indígenas?”, foi enfática: “-Em todos!" Lembrou que no sítio de Cananéia, no atual porto da cidade, foi identificada urna funerária, da mesma forma que na praça posterior da Matriz de Iguape.

É significativo que, nesta fase embrionária, duas povoações ocupassem locais diferentes dos sítios para onde foram transferidas no seqüenciamento colonial. Icapara, próxima de Iguape e Maratayama, em frente Cananéia, correspondiam à simplicidade das aldeias primitivas (figura 43, p. 122). Com o advento de projetos coloniais mais consistentes, foram escolhidas novas áreas pelos colonizadores, muito em função dos binômios praça-matriz e da projeção populacional. Observa-se que, em ambos os casos, os novos sítios escolhidos, apropriados aos novos programas, recaíram também onde existiram aldeias indígenas, conforme prospecções arqueológicas. O importante, na gênese dos processos urbanos, são os contextos históricos e ambientais. A sutileza da arquitetura nas instalações físicas entre aldeias e povoações embrionárias é suplantada pelo significado da apropriação ambiental. A partilha dos mesmos sítios, dos mesmos lugares de vivência, da mesma inserção ecológica vital à sobrevivência dos europeus que gradativamente chegaram, relevam como da maior importância os espaços préocupados para os futuros delineamentos urbanos. A arquitetura urbana portuguesa, decerto se instalará na região vicentina nos dois primeiros séculos do colonialismo, mesmo simplória. Mas os sítios e os caminhos de articulação da rede serão quase que totalmente superpostos aos lugares de vivências das sociedades pré-coloniais.

Os primeiros olhares descobridores focaram-se na identificação dos portos. Sem eles não haveria comércio nem domínios. Serão os espaços vitais da Idade Moderna, portas do mercantilismo em suas diversidades. Evidentemente foram as principais referências observadas por Gonçalo Coelho, já que comandava uma 
expedição de reconhecimento, com os necessários fundeios para as "aguadas" e tomadas de altura do sol no registro das latitudes. Aspectos gerais da costa decerto foram anotados pela missão para elaboração dos mapeamentos e "cartas" de navegação. Mas os portos, muitas vezes associados aos estuários dos rios, destacavam-se nestas representações por viabilizarem as conquistas e as posses. Foi como as localidades de Cananéia e S. Vicente logo se integraram nas rotas do mundo.

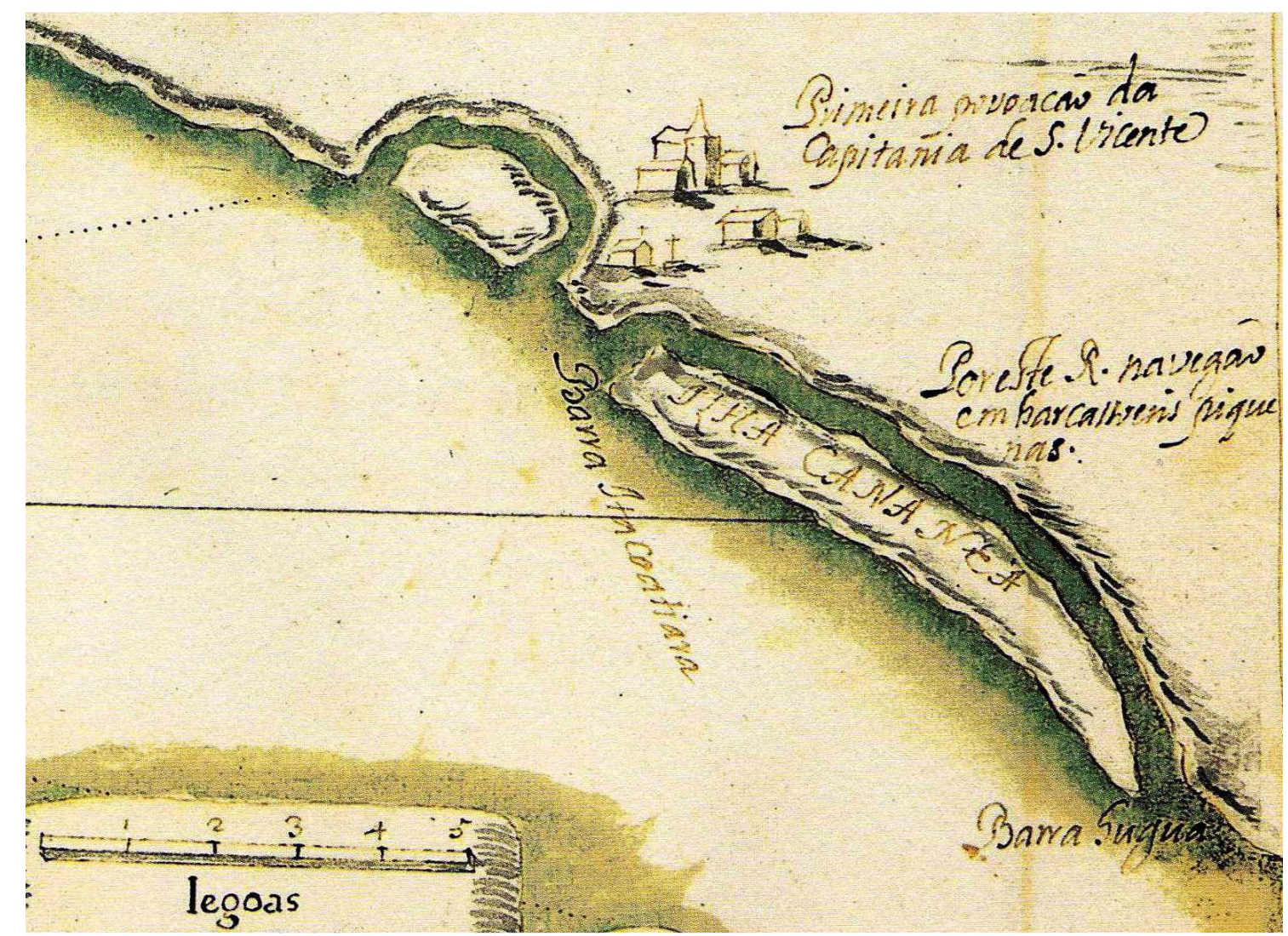

Figura 45. Cananea. Detalhe da Carta 4 da "Descripção de Todo o Maritimo da Terra e S. Cruz Chamado Vvlgarmente o Brazil". Feito por João Teixeira Cosmographo de Sua Magestade, Anno de 1640 (“João Teixeira Albernaz l"). Fonte: MARTINS, 2003.

A Barra de Cananéia, ou Barra Itacoatiara, portal sul do sistema lagunar estuarino contido pela Ilha Comprida, ou Ilha de Cananéia, limita o acesso de navios de grande nas águas interiores. Além da manobrabilidade exigida, a passagem tem pouca profundidade, atenuada nas marés altas. Porém, na porção oceânica, há outra ilha de topônimo revelador que supre essa carência: a ilha do Bom Abrigo 


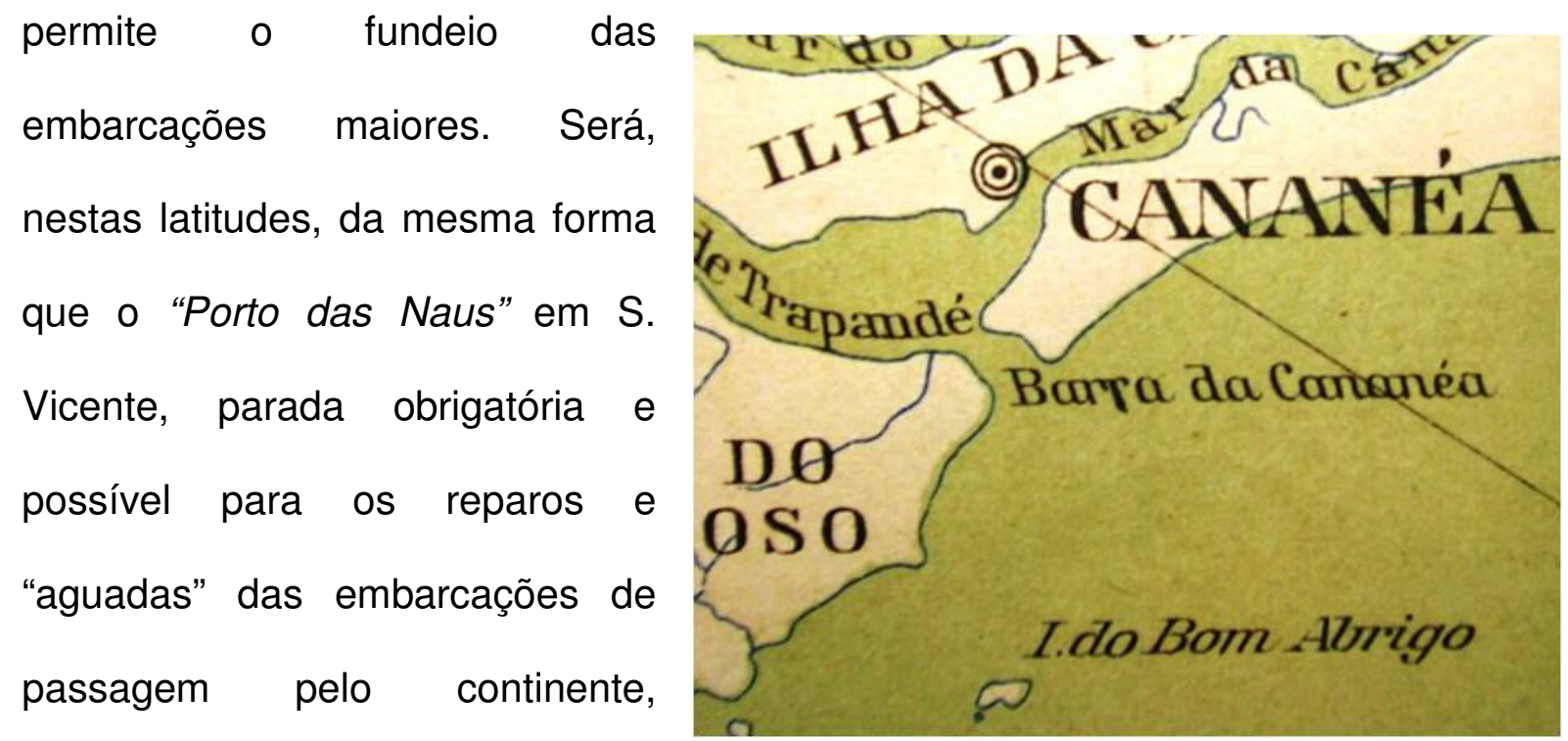

especialmente em direção ao cone

Sul ou a caminho das Índias. Os

Figura 46. Bom abrigo. Detalhe da Planta do Litoral do Estado de São Paulo entre a Barra do Ararapira e Juruvaú. CGGESP, 1920. Fonte: Biblioteca FAUUSP, LR 918.161 Sa63Ls.

contatos com as instalações do continente eram feitos geralmente com embarcações menores de apoio. Foi o que aconteceu na primeira ancoragem da esquadra de Martim Afonso nessa região, crucial aos destinos de sua expedição. Texto do Historiador Mário Neme, baseado no "Diário da Navegação" de Pero Lopes de Sousa, informa:

Pelo que diz o cronista de viagem, a arribada à ilha de Cananéia foi um ato fortuito que não estava no plano de Martim Afonso. (...) Naquela ilha resolveram aportar (...) porque o tempo, que havia muito estivera encoberto, limpara repentinamente e a ilha de Cananéia [Bom Abrigo] Ihes surgiu pela frente. (...) Aí o capitão-mor manda o piloto Pero Anes, "língua da terra", num bergantim com companheiros a pesquisar pela terra a dentro. Em cinco dias regressam trazendo um certo "bacharel", português que havia trinta anos vivia por ali; trazem mais alguns castelhanos, entre os quais um Francisco Chaves, que combina com Martim Afonso dirigir uma entrada pela terra a dentro, da qual em dez meses promete voltar com quatrocentos escravos carregados de ouro e prata. Oitenta homens partem com Francisco Chaves, sob as ordens de Pero Lobo (NEME, 1959, p. 71).

Já vimos que essa expedição não logrou êxito. Mas ressalta a estratégia da localidade nas conexões marítimas e continentais. 


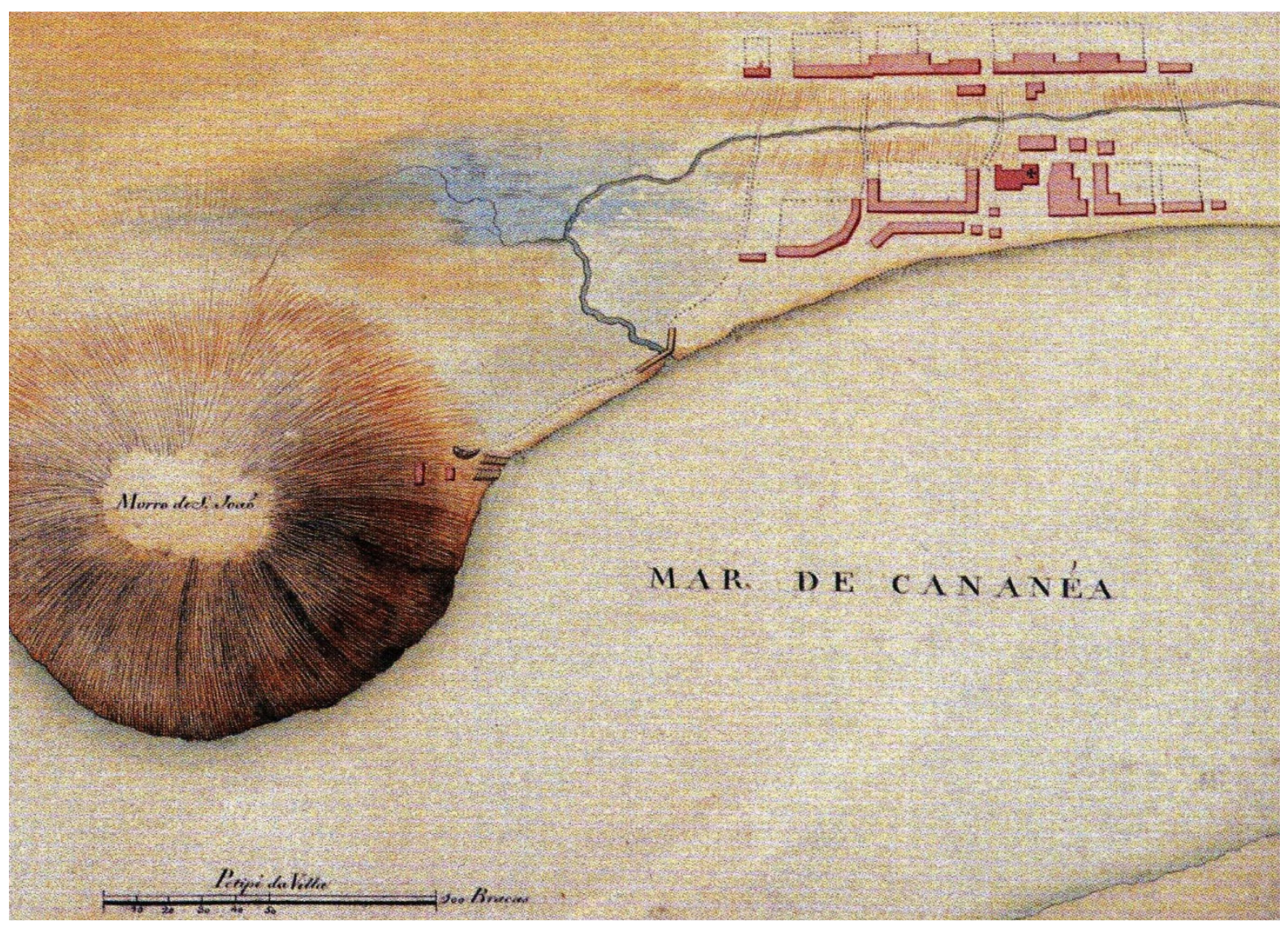

Figura 47. "Villa de Cananéa". Detalhe de uma das "Cartas Corographicas e Hydrographicas...", de João da Costa Ferreira, 1815. Fonte: REIS FILHO, 2001, p. 204.

O sítio da ocupa um altiplano salubre, destacado em uma das ilhas internas do lagamar, típicas de planície costeira. Estão presentes as fontes de água doce e o notável resguardo dos ventos de sudoeste representado pelo morro de São João. São vetores dos nichos ecológicos identificados nas ocupações pregressas. Nesta caso o agenciamento destes fatores é determinante. Vemos na figura da página seguinte que no entorno do sítio escolhido não se encontra outra elevação do relevo. Tal qual na llha de São Vicente, somente de suas encostas é que verte água potável. Quando provenientes das áreas planas, os riachos têm sua origem em terrenos alagadiços ou brejais. A adjacência ao porto natural do Mar Pequeno e a próximidade do portal marítimo, encerram o quadro ambiental de sua sustentabilidade. 


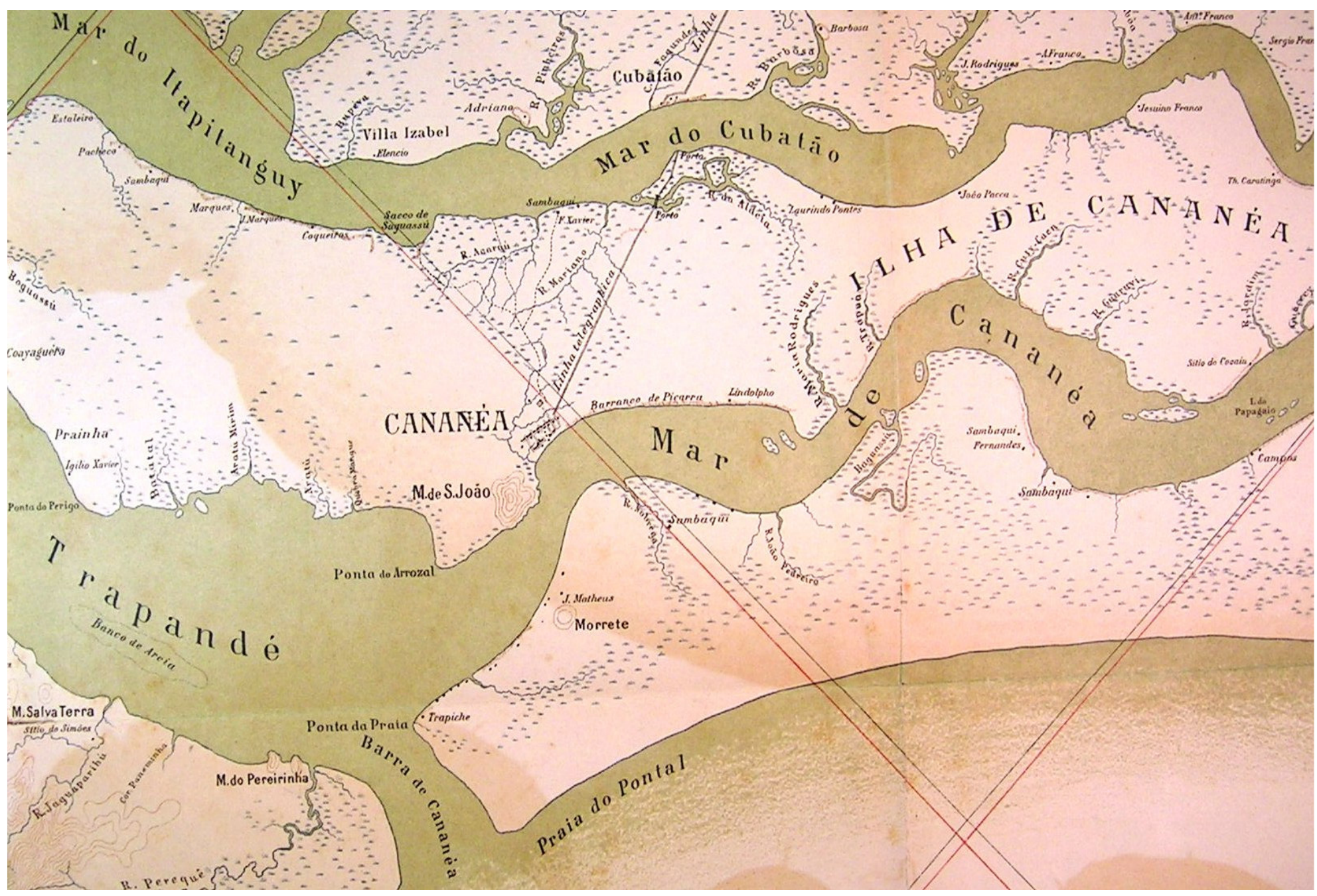

Figura 48. Virtudes da escolha. Detalhe da Planta do Litoral do Estado de São Paulo entre a Barra do Ararapira e Juruvaú. Levantamento Comis. Geogr. e Geol. do ESP, 1920. Fonte: Biblioteca FAUUSP, LR 918.161 Sa63Ls. 


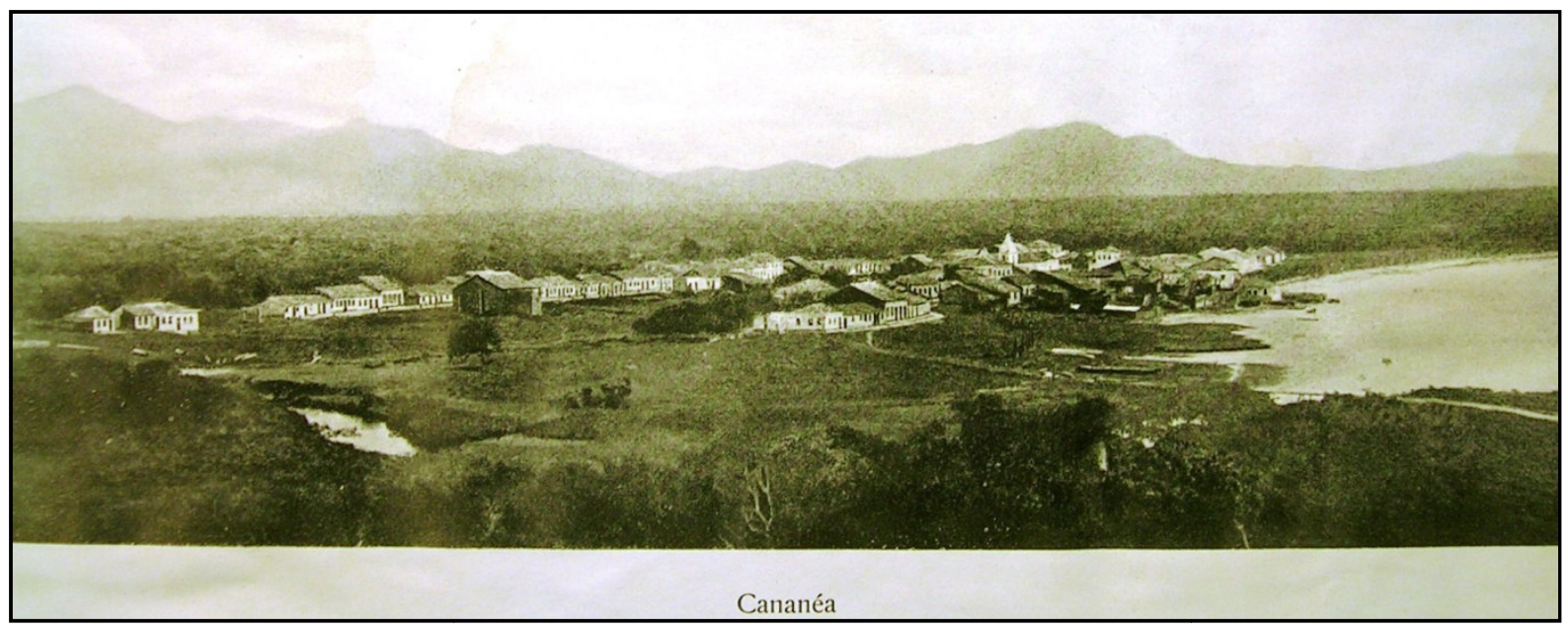

Figura 49. 1920. Vista do Morro de São João. Foto do livro Exploração do Litoral $2^{a}$ Secção - Cidade de Santos à Fronteira do Estado Do Paraná. Levantamento da Comissão Geogr. e Geol. do Estado de São Paulo, 1920. Fonte: Biblioteca FAUUSP, LR 918.161 Sa63Ls.

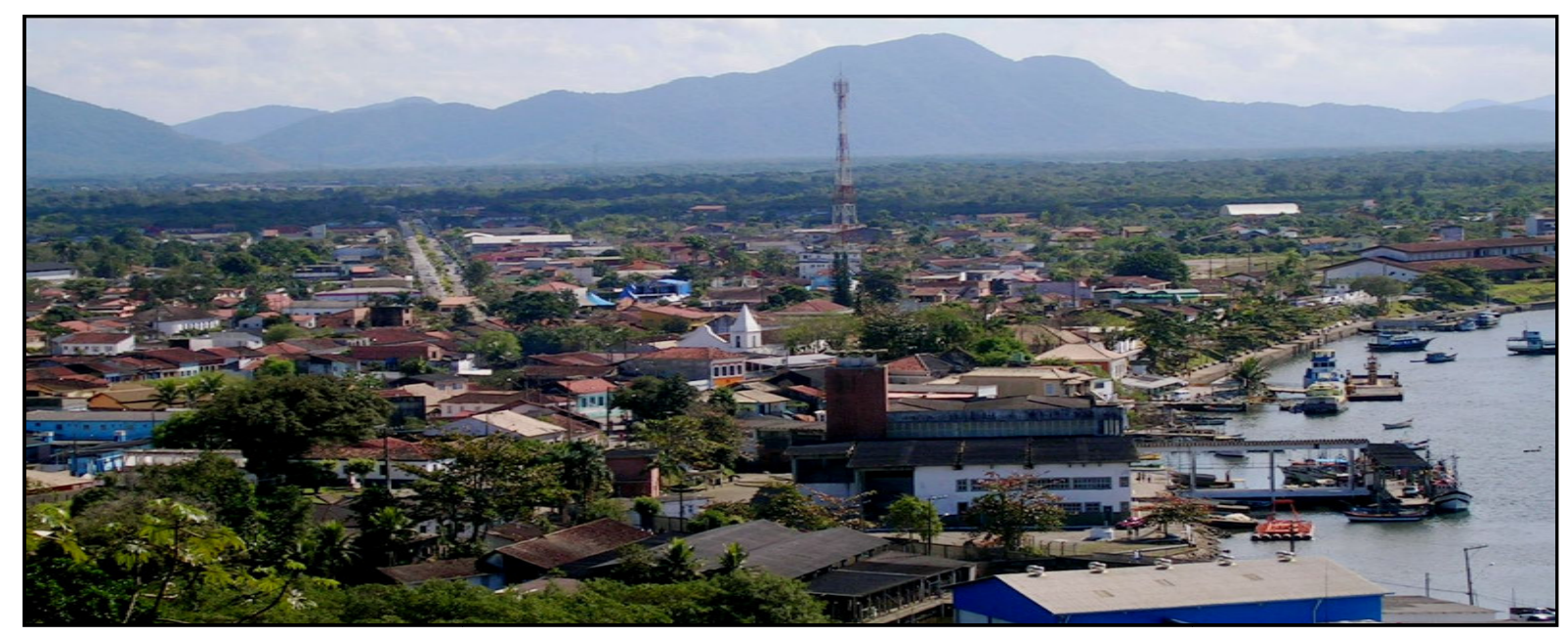

Figura 50. 2005. Vista do Morro de São João. A pesca é a principal atividade econômica de Cananéia. Foto do autor, 2005.

Não há registro sobre a localização da povoação germinal de Cananéia, Maratayama ou Boa Vista. A citação do geógrafo A. Paulino de Almeida é imprecisa: "O primeiro povoado de Cananéia [...] teve assento na ilha Comprida, no lugar denominado - Boa Vista, - quase em frente à atual cidade, de onde [...] foi transferida na aurora do século XVII para a ilha de Cananéia [...]." (ALMEIDA, 1952, p. 12). A tradição oral aponta a localização assinalada na Figura 51 adiante. Parecenos incongruente, tanto pelo designativo de Boa Vista, muito mais pertinente ao Morro de São João (o local indicado é mais baixo do que o platô de Cananéia!), 
como pela ausência, no local suposto, de água doce com as mesmas virtudes do sítio seqüencial. Somente investigações arqueológicas poderiam desvendar a veracidade dessas informações. A planta da região, fruto dos levantamentos elaborados pela Comissão Geográfica e Geológica do Estado de São Paulo no início do século passado, informa claramente a direção da articulação continental do núcleo urbano. É o caminho de interiorização através da planície costeira que intercepta a calha do rio Ribeira, diretriz do Peabiru conforme Nota 6 da página 123.

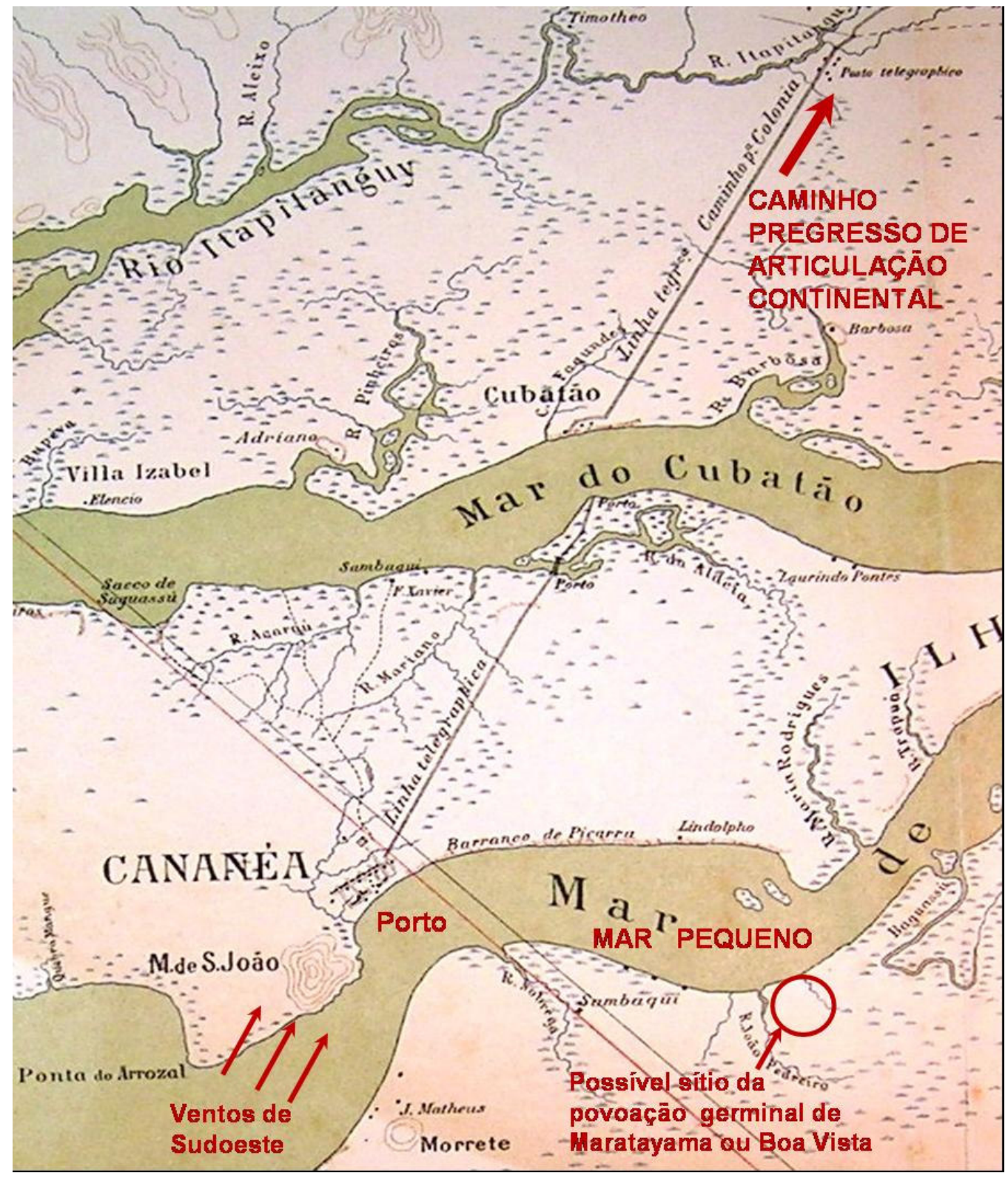

Figura 51. Vetores. Det. da Planta do Litoral... mencionada, 1920. Fonte: Biblioteca FAUUSP, LR 918.161 Sa63Ls. Acrescentados textos e sinalizações do autor. 
Segundo Aroldo de Azevedo, Cananéia foi elevada à vila em 1600. (AZEVEDO, 1956, p. 14). No entanto, a primeira capela, cujas fundações foram descobertas por ocasião do restauro da Matriz atual, no espaço do altar-mor, tem seu registro no ano de 1578. Procede com as informações de Paulino de Almeida, segundo o qual, "A primeira doação de terras na ilha de Cananéia foi feita aos padres, no ano de 1601, 'para fazerem suas casas, mosteiro e quintais, por terem sido eles os fundadores da vila em seus princípios." (ALMEIDA, 1952, p. 12).

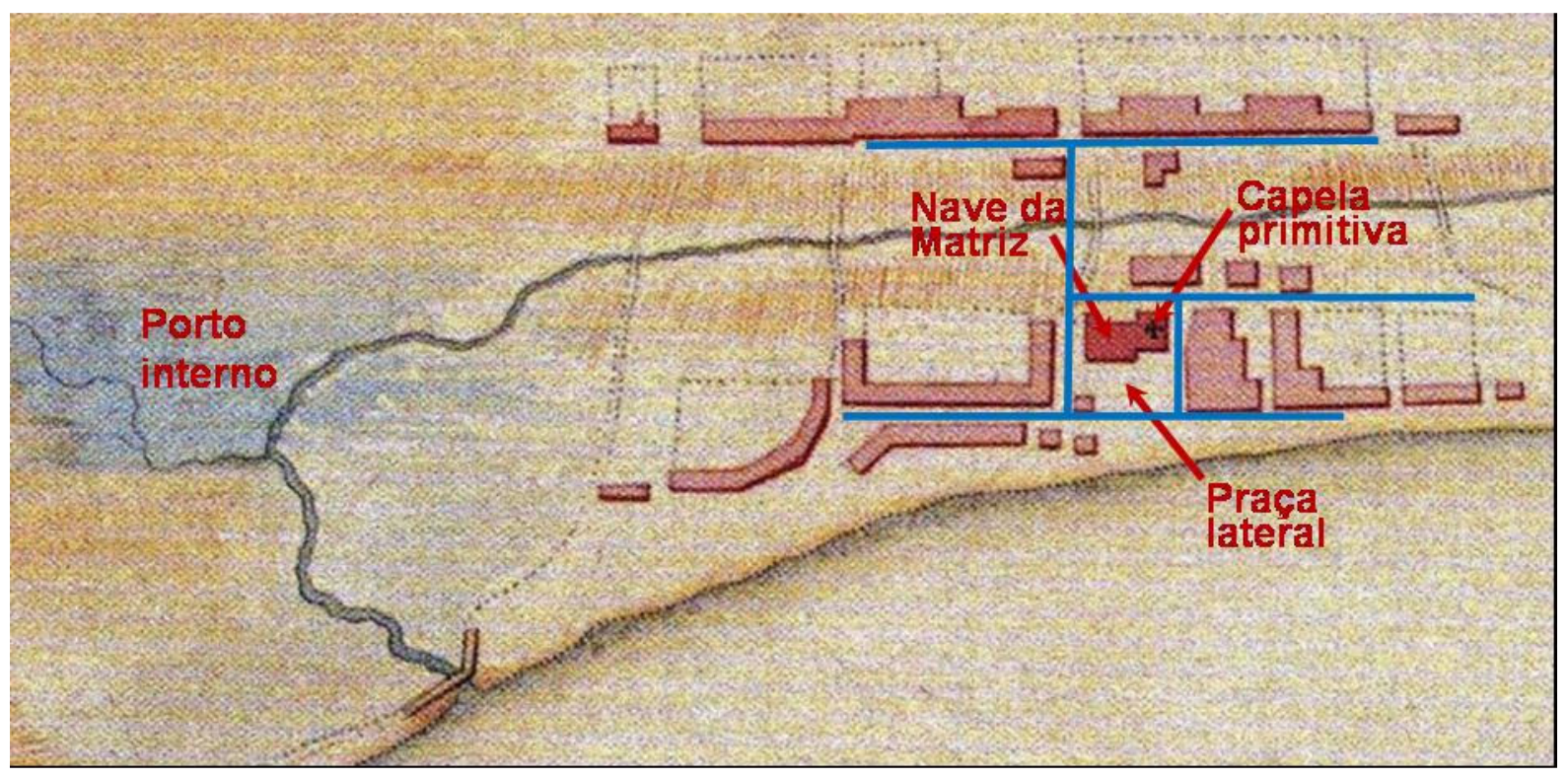

Figura 52. O desenho. Detalhe de uma das "Cartas Corographicas e Hydrographicas..." mencionada, 1815. Fonte: REIS FILHO, 2001, p. 204.

A implantação da Matriz manteve a mesma disposição da capela anterior. Toda a área da nave atual, portanto, corresponde ao antigo adro, ocupado na ampliação. Assim, estranha-se que o vazio diante da Matriz seja restrito à largura da rua lindeira ao frontão, pois do outro lado da via, o altiplano do sítio é interrompido pela declividade da micro-bacia do córrego indicado na figura acima. Este córrego, denominado Olaria, ainda hoje dá acesso a um pequeno porto no interior da ilha, utilizado por embarcações de pesca artesanal. Esse atrativo na parte mais baixa do 

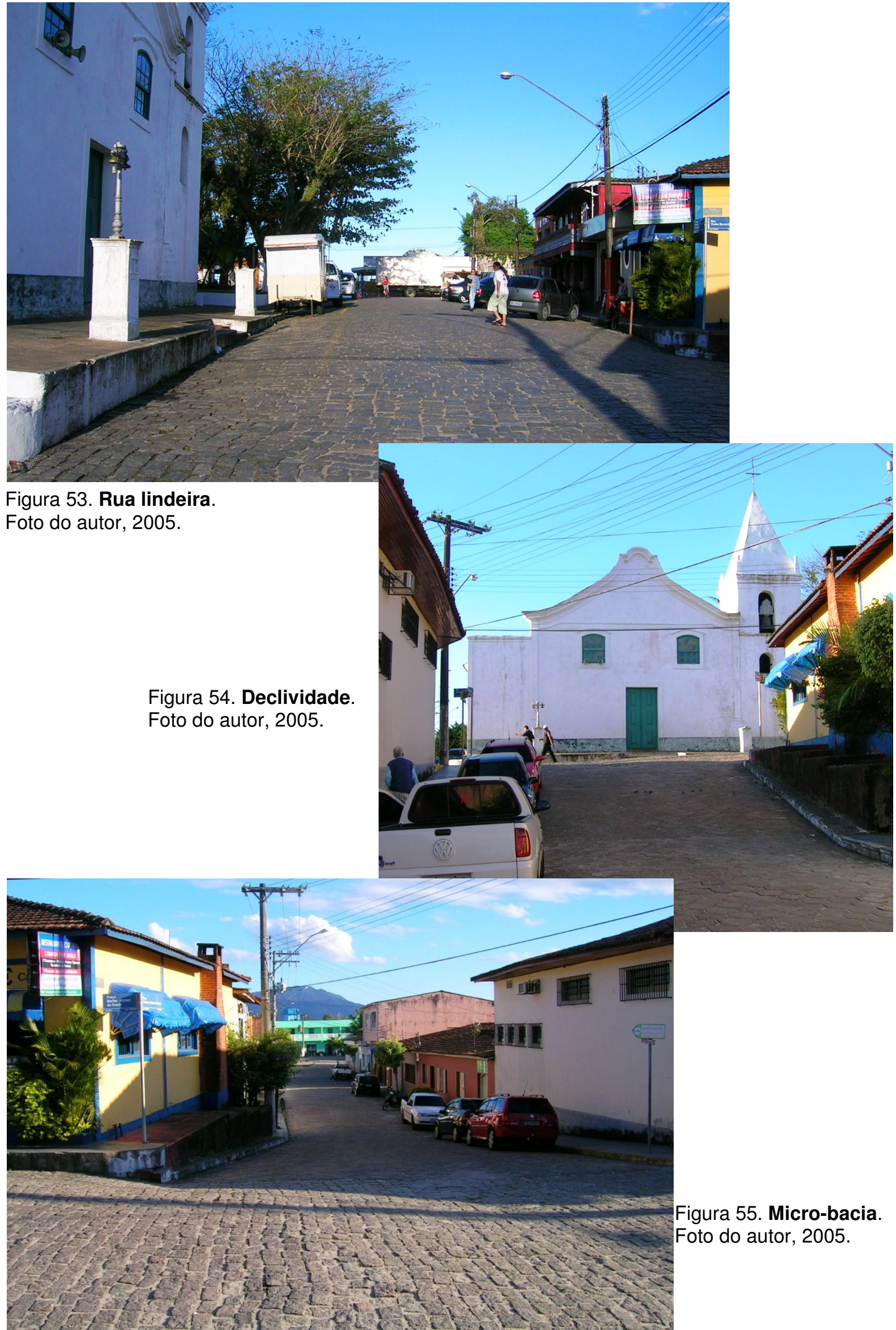

Figura 55. Micro-bacia Foto do autor, 2005. 


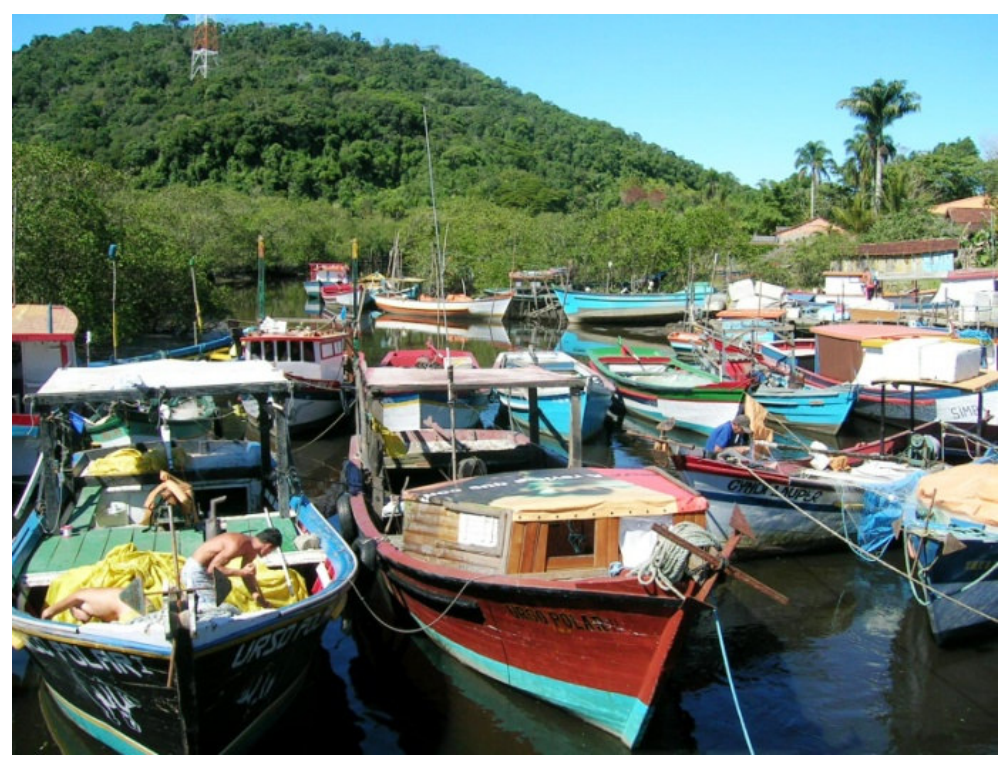

Figura 56. Porto interior. Ao fundo o Morro de São João. Foto do autor, 2005.

sítio pode justificar a direção para onde foi voltada a capela primitiva, considerando sua proeminência no altiplano em relação ao terminal do meio de transporte mais utilizado pelas comunidades primitivas: a canoa indígena. Mas o adro de pequena amplitude é compensado pela praça lateral do edifício religioso, espaço social valorizado com a adjacência do porto principal no Mar Pequeno. Na Igreja está evidente a preocupação com a defesa. Suas paredes laterais apresentam "flexeiras" verticais como recurso. Tanto procediam que, tempos depois de sua construção, o autor do prospecto anexo adiante, Engenheiro Militar José Custódio de Sá e Faria, quando alí esteve por volta de

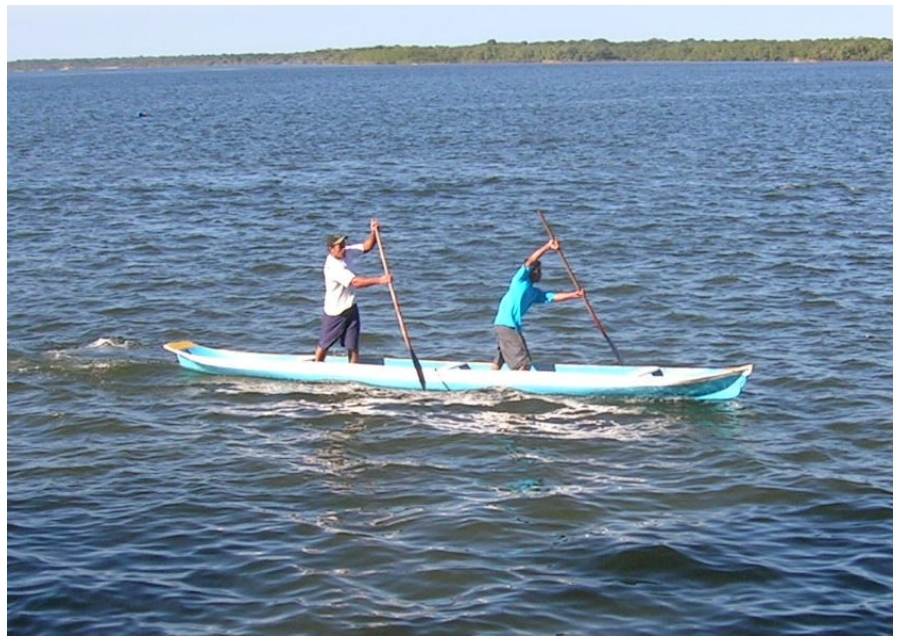

Figura 57. Canoa no Mar Pequeno. Foto do autor, 2005.

1769, provavelmente providenciou empenas laterais como gigantes para reforçar as paredes, portanto, revitalizando os mesmos critérios defensivos.

No desenho de João da Costa Ferreira (Figura 47, p. 128), o mais remoto, não foi possível identificar com precisão o vínculo entre o traçado das ruas da vila e 
o alinhamento do caminho continental de Cananéia. Sua contigüidade no intraurbano geralmente configura a "rua direita" do aglomerado. Nas vilas de Santos,

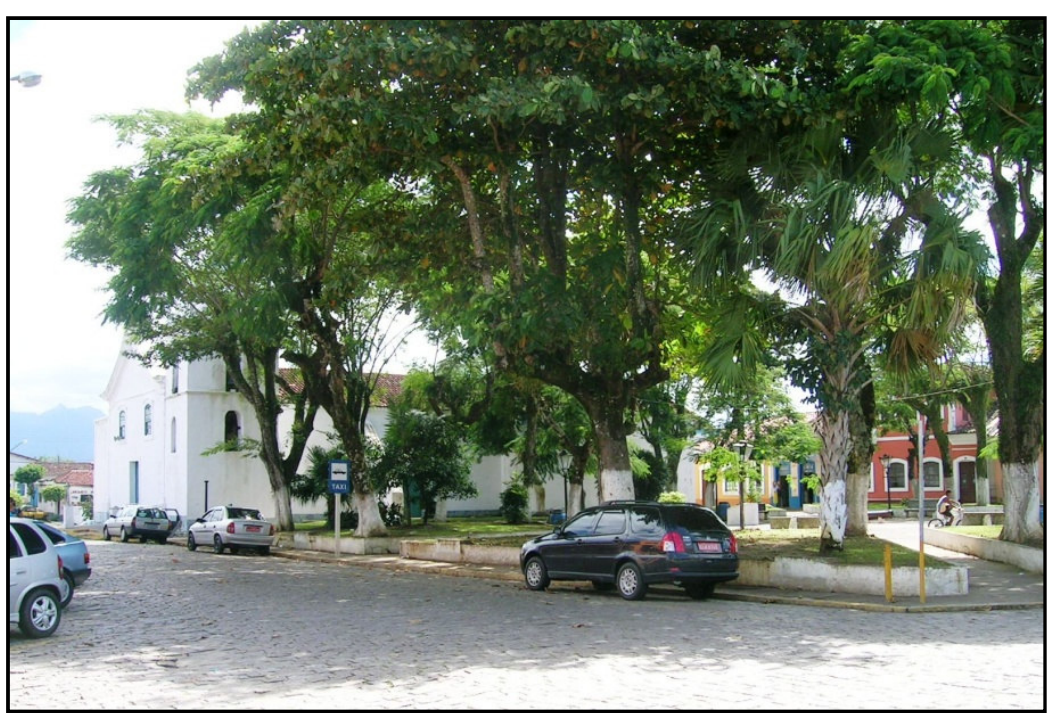

Figura 58. A praça lateral. Foto do autor, 2005. Iguape, São Sebastião e Ubatuba, esta diretriz é uma das componentes delineadoras do desenho urbano. Podem evidenciar - seqüenciamento de instalações coloniais a partir dos espaços de produção pregressa. $\mathrm{Na}$ planta da Comissão Geográfica e Geológica de 1920, a articulação do caminho com o tecido urbano é angular, parece corresponder a uma adequação evolutiva. Todavia, é significativo que a projeção do seu alinhamento alcance o embrião primitivo da povoação.

Pensamos que a geometria do módulo urbanístico primário, do binômio Praça/Martriz, pode ter delineado $o$ traçado da expansão, com os seus vetores prevalecendo sobre a diretriz primitiva no contexto intra-urbano.

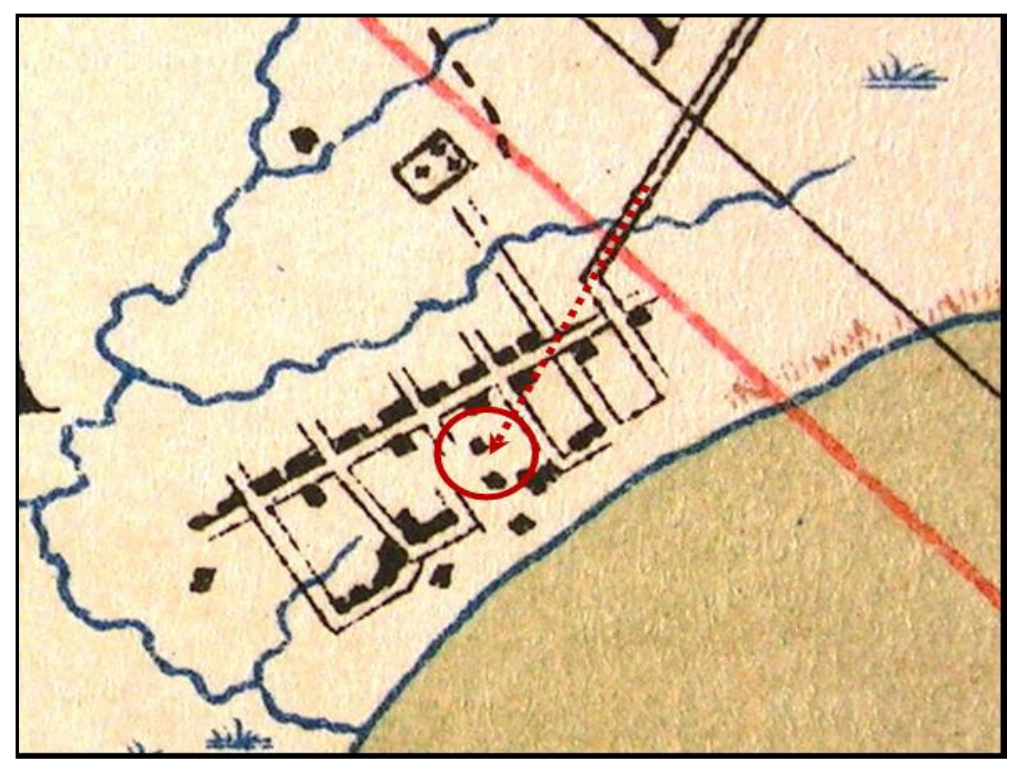

Figura 59. Projeção do passado. Det. da Planta do Litoral... mencionada, 1920. Fonte: Bibl. FAUUSP, LR 918.161 Sa63Ls. Acrescentadas sinalizações do autor. 


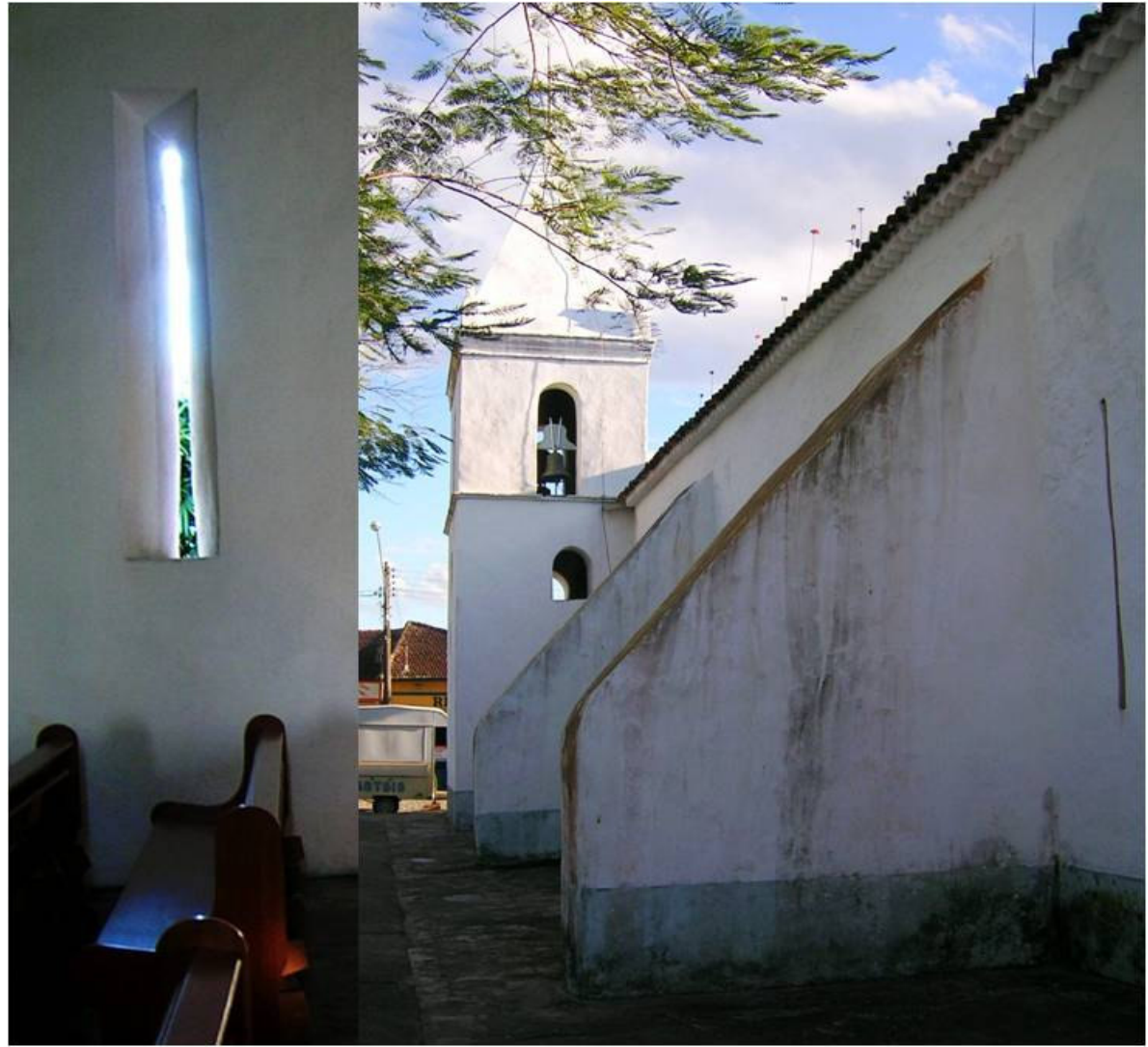

Figura 60. A defesa. Os gigantes de 1769, ao que parece providenciados por José Custódio de Sá e Faria (TOLEDO, 1981, p. 83). No detalhe, a "flecheira". Fotos do autor, 2005.

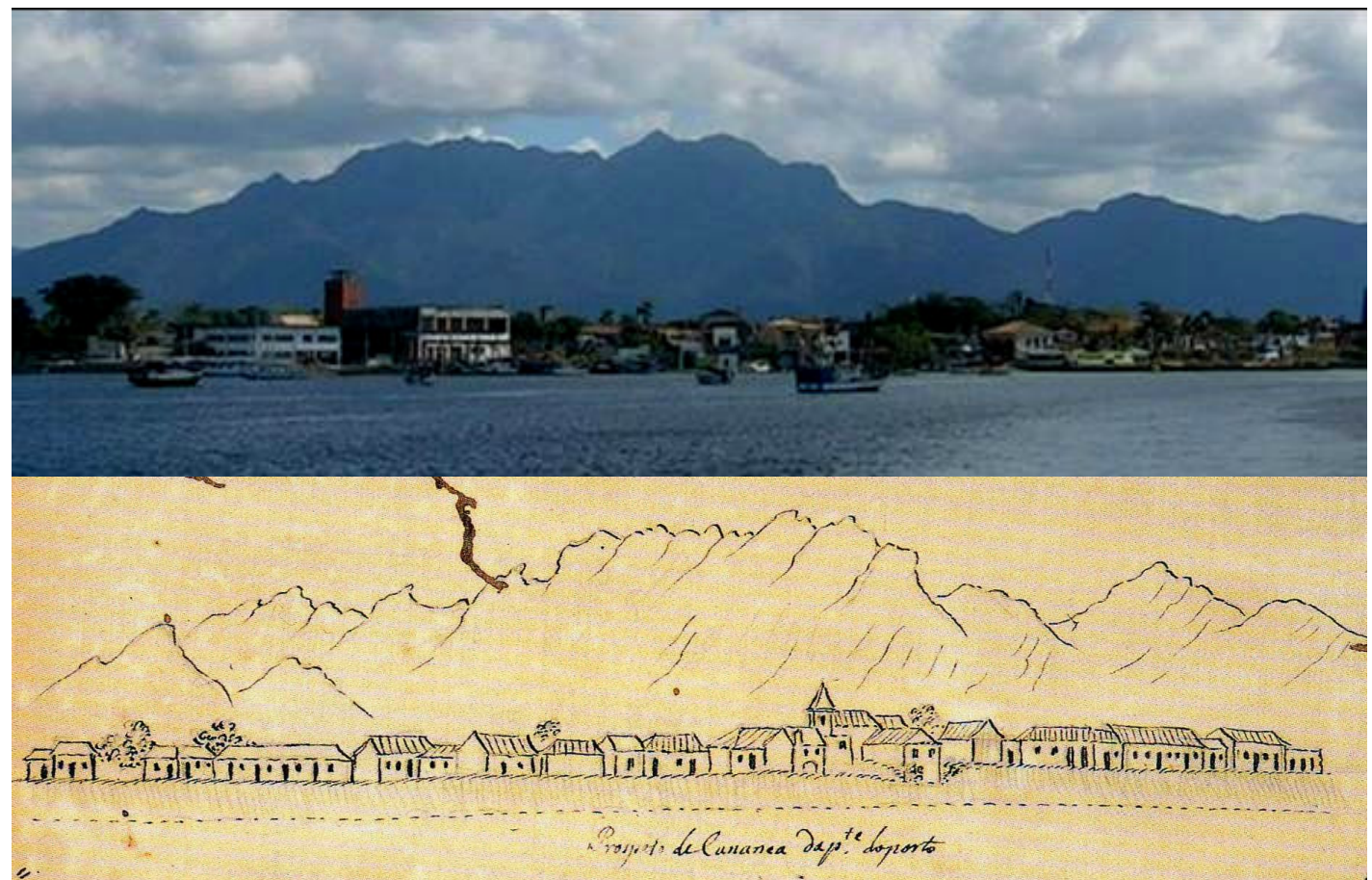

Figura 61. "Propeto de Cananea da pte. do porto". Detalhe do desenho do Eng. José Custódio de Sá e Faria, 1776. Era comum adotar-se a técnica da "quadrícula" (grade de tela quadrada com ponto fixo de observação), para se desenhar parcialmente a imagem de cada campo observado, estendendo-se a precisão das partes na continuidade das linhas traçadas. Fonte: REIS FILHO, 2001, p. 204. 


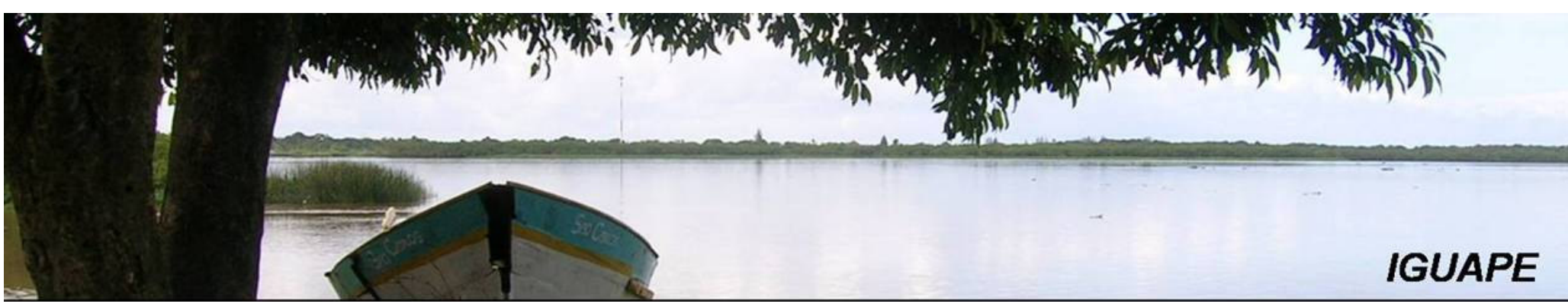

\section{6 "Villa de Nossa Senhora das Neves de Iguape"}

Iguape situa-se na porção continental do lagamar, nas proximidades do "portal" norte da Ilha Comprida conhecido como Barra de Icapara. Nas adjacências encontra-se também o estuário do rio Ribeira de lguape (Figura 62, p. 138). Os caudais desse rio são expressivos: drenam a maior planície costeira da frente atlântica do Estado de São Paulo. Ao contrário do litoral Norte, a partir da baixada vicentina, a serra do Mar afasta-se progressivamente dos limites marinhos na direção sudoeste, permitindo planícies de maior amplitude até configurar a bacia hidrográfica do Ribeira. Ao sul deste amplo "anfiteatro", no entorno de Cananéia, a serra debruça novamente seus contrafortes no mar e prossegue em direção ao sul. Assim, a paisagem geográfica dessa região, contida pelo relevo serrano, parece representar o relativo isolamento regional que perdura até hoje perante o conjunto de atividades sociais do Estado de São Paulo.

O sítio do núcleo urbano insere-se na paisagem das águas. Estratégico, interpõe-se entre a porção norte do sistema lagunar estuarino e o baixo Ribeira. A percepção da vitalidade ambiental decerto remonta à nossa pré-história. Os remotos sambaquis e os grupos locais de subtradição Tupi evidenciados reiteram sua exuberância. O seqüenciamento europeu, portanto, é um desdobramento previsível. 


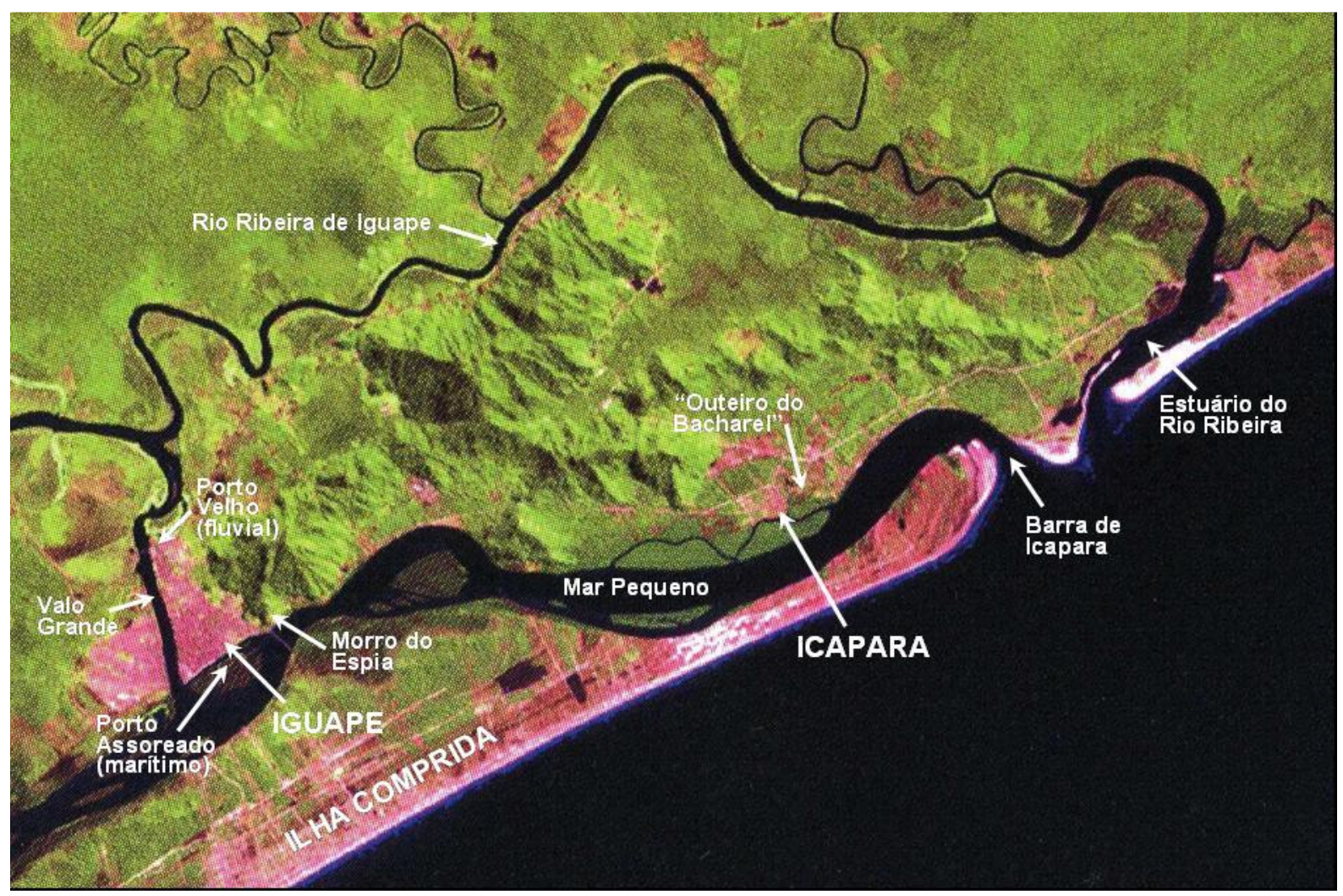

Figura 62. A interação das águas. Fonte: : AB'SÁBER, 2005, p.235. Acrescentados textos e sinalizações do autor.

O nosso Bacharel, interagindo com a sociedade Tupi, estabelece-se também em Icapara. O historiador Ernesto Young (1902), em Subsídios para a história de Iguape, afirma: "[...] a primeira povoação e villa de Iguape de que temos provas incontestáveis, existia ao pé de um pequeno monte chamado 'Oiteiro do Bacharel." (YOUNG, 1902, p. 225). A seguir informa que o outeiro localiza-se em frente à Barra de Icapara, pelo lado de dentro, e que hoje é conhecido pelo nome de "Morro do Icapara”. Adiante reitera: “[...] é provado que existia uma povoação ao pé do 'Outeiro do Bacharel' anteriormente ao anno de 1577, anno este em que [foi] aberto um Livro do Tombo da Egreja dedicada a Nossa Senhora das Neves". (YOUNG, 1902, p. 226).

Após o retorno de Martim Afonso de Souza a Portugal, o povoado foi palco de uma crise que passou para a história: a "Guerra de Iguape". Talvez seja o primeiro conflito armado entre europeus travado na América do Sul. As tensões com os 
portugueses de São Vicente se acirraram quando chegou ali, "no anno de 1533", o tenente espanhol Ruy Garcia Moschera, "[...] vindo do rio da Prata [...] com alguns companheiros[...]." (YOUNG, 1902, p. 233). Foi acolhido por Cosme Fernandes Pessoa, o Bacharel, no seu reduto de Icapara. O anfitrião, no entanto, estava sob intimação: Pero de Góis pretendia prendê-lo e interrogá-lo para descobrir se estava envolvido no massacre da entrada de Pero Lobo. Era uma desconfiança de Martim Afonso, que não se conformava por não ter alcançado as riquezas do Peru e deixara esta determinação a Pero de Góis antes do seu retorno. O Bacharel não se entrega e o intrépido tenente Moschera, tomando suas dores, responde que "[...] não conhecia ser aquela terra da coroa de Portugal, senão de Castela." Com o impasse criado, São Vicente envia um esquadrão de 80 combatentes para por fim ao povoado, mas é rechaçado pelos espanhóis que para isso estavam preparados com trincheiras. Estes, animados pela vitória, a bordo de uma nau francesa que haviam capturado em Cananéia, invadem, saqueiam e incendeiam o vilarejo de São Vicente. Foi no ano de 1534. Depois do episódio, Mosquera e seu grupo fogem para Santa Catarina. O Bacharel permanece nas povoações do sul até não se ter mais notícia.

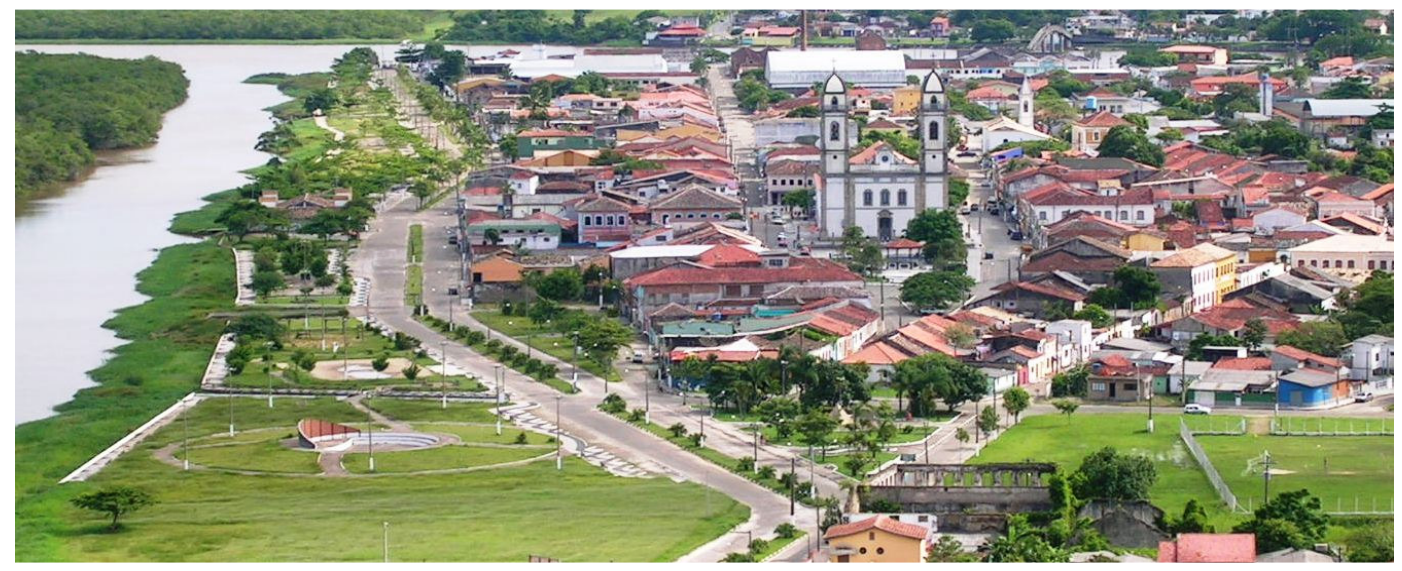

Figura 63. Novos sítios, velhas escolhas. Foto do autor, 2006.

A mudança da "vila velha" de Iguape para o sítio atual ocorrerá no século seguinte. "É geralmente citado o anno de 1654 como sendo aquele em que foi 
elevada [à vila]." (YOUNG, 1902, p. 236). O autor, no entanto, enumera diversos documentos que indicariam sua elevação em época anterior, antes mesmo da mudança, "[...] e que esta mudança foi effectuada durante os anos imediatamente anteriores a 1637, em cuja data ficou concluída a Igreja Matriz." (YOUNG, 1902, p. 238). Adiante, Young escreve: "Os terrenos, por ocasião da mudança da Villa, pertenciam a Francisco Alves Marinho, descendente de Cosme Fernandes e Francisco de Chaves." (YOUNG, 1902, p. 241, grifo nosso).

Com o mesmo perfil de Cananéia, as novas instalações de Iguape, atendendo aos novos programas do colonialismo, ocupam sítio plano de planície costeira, adjacente às águas, ligeiramente elevado em relação ao entorno ${ }^{8}$, com área suficiente à escala de implantação dos seus contextos sociais. Não perdem os atrativos ambientais que os viabilizam. Não por acaso, recaem em área de escolha pregressa indígena 9 .

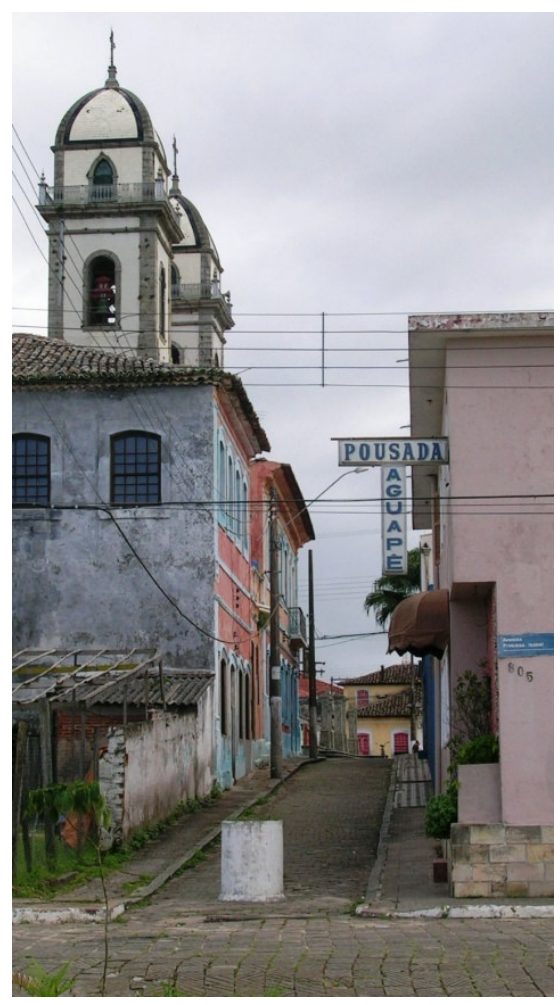

Figura 64. Altiplano. Notar elevação da área central. Foto do autor, 2006.

\footnotetext{
${ }^{8}$ Ernest Young informa sobre o sítio da nova Vila: "A altura deste terreno sobre o nível do mar varia entre 0 e 10 metros, sendo na maior parte 5 a 6 metros acima das marés cheias." (YOUNG, 1902, p. 239).

${ }_{9}$ Conforme Maria Cristina Scatamacchia, "É quase certo que a própria cidade de Iguape esteja situada sobre uma antiga aldeia indígena, pois em várias ruas do perímetro urbano foram identificados vestígios cerâmicos, tendo a SABESP, há uns cinco anos atrás, executando trabalhos de saneamento, encontrado uma urna no largo da matriz." (SCATAMACCHIA, 1990, p. 203). Sobre Cananéia, informação verbal da Arqueóloga também relata o encontro de uma urna funerária na área do porto da cidade.
} 


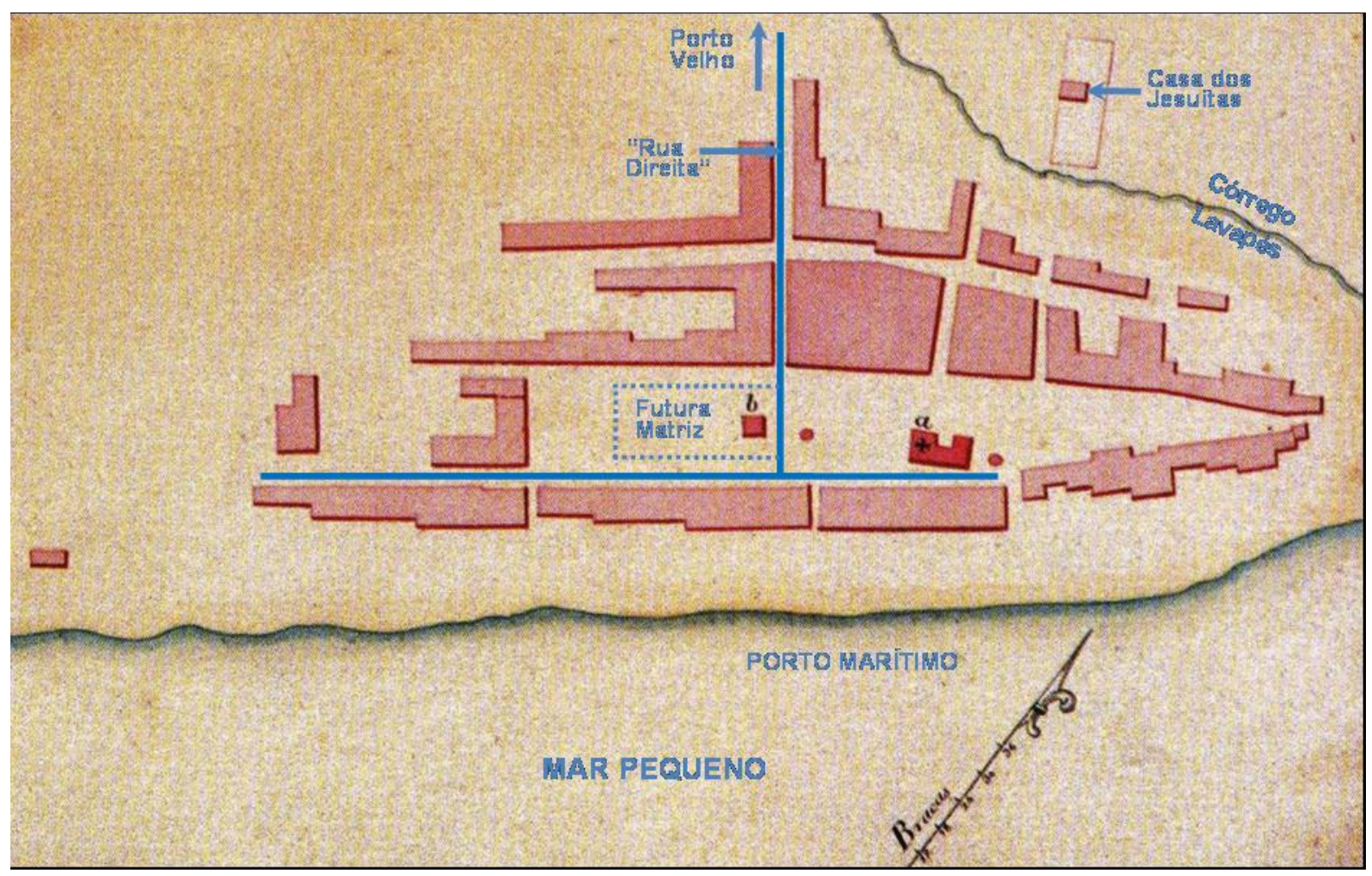

Figura 65. Vetores urbanos. Detalhe de uma das "Cartas Corographicas e Hydrographicas...", de João da Costa Ferreira, 1815. Fonte: REIS FILHO, 2001, p. 203. Acrescentados textos e sinalizações do autor.

O levantamento de João da Costa Ferreira, com a mesma linguagem de representação das outras vilas, revela intrigante implantação do edifício religioso no desenho urbano. Ressalvada a adequação ambiental das linhas no "funil", imposição limítrofe do sítio no altiplano conformado pelo Córrego Lavapés, afluente do Mar Pequeno, os alinhamentos da praça parecem adequados à perpendicular da "rua direita", diretriz do porto fluvial do Rio Ribeira, indicada a Noroeste. Sabemos que a instalação da Matriz na vila, com as obras iniciadas em 1614, foi uma das primeiras providências dos colonos para a mudança da sede, que ocupava o povoado de Icapara. A historiografia informa também que as primeiras casas foram "arruadas" no alinhamento paralelo ao porto marítimo do Mar Pequeno (FORTES, 2000, p. 169), coerente com o talude das bordas do altiplano, portanto um traço ambientado à topografia e adequado à ortogonalidade da futura "rua direita". A locação da Igreja sugere uma premência descompromissada com as subseqüentes edificações do 
núcleo. Porém, sua representação pode estar equivocada. Os historiadores Ernest Young (1902) e Roberto Fortes (2000) informam que os alicerces da antiga Matriz

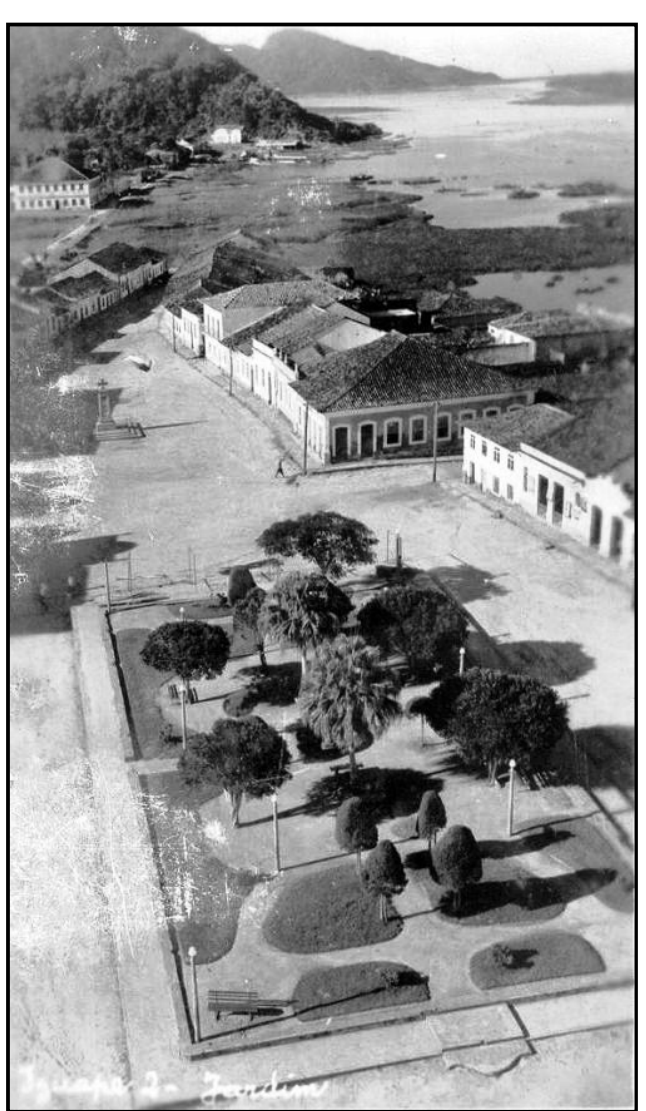

Figura 66. Alicerces. Fonte: $h t t p: / /$ robertofortes.fotoblog.uol.com.br

foram mantidos após a demolição e aproveitados para o enquadramento dos jardins da praça. Desta forma, a implantação primitiva parece corresponder à ortogonalidade da Matriz atual. A distorção visual da Figura 66 é relativa, tendo-se em conta a posição do fotógrafo na torre direita de quem olha para o santuário. $\mathrm{Na}$ Figura 67, com a objetiva possivelmente perpendicular ao frontão e centrada no eixo do jardim, o paralelismo parece preciso, claramente verificado na Figura 68, que também evidencia um deslocamento entre o eixo do jardim e o eixo do edifício religioso. Mas o centralismo da imagem, observado na Figura 67, pode ser entendido com o fotógrafo criterioso colocando-se na janela esquerda do coro, de quem olha para o frontão, como vemos na Figura 68. Em relação ao desenho de João da Costa, não há registro da existência de outra Matriz na Vila, sendo que a Basílica atual teve seu início provável em 1787 e inauguração em 1856. A disposição do

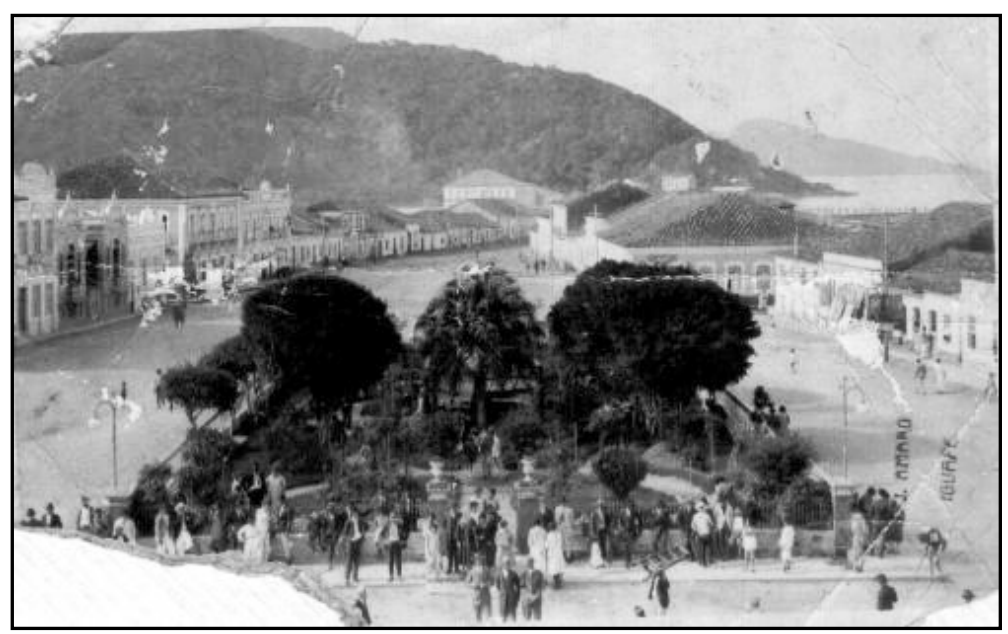

Figura 67. Eixos. Fonte: http://robertofortes.fotoblog.uol.com.br 
desenho pode ser validada se não proceder a informação de que os alicerces da velha Matriz foram reutilizados.

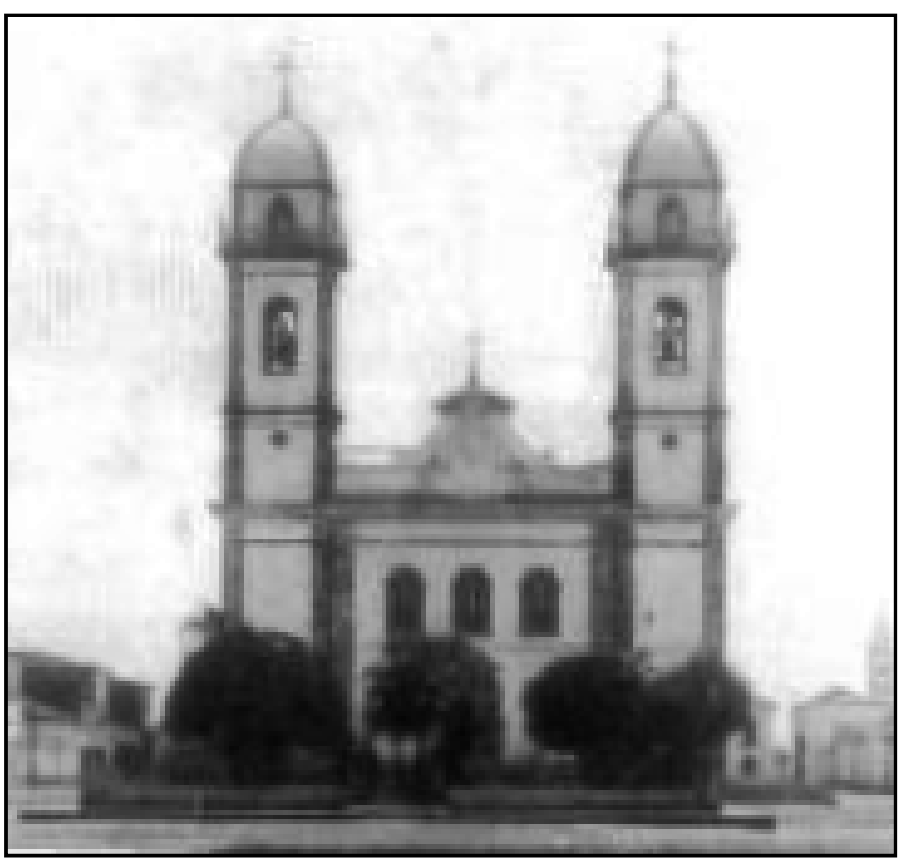

Figura 68. Paralelas. Fonte: http://robertofortes.fotoblog.uol.com.br
A "rua direita", no entanto, é claramente identificada. Assim se chamava desde 1839 até mudar a denominação para Rua 9 de Julho, mantida até hoje. Perpendicular à praça, sua diretriz polariza significativamente o Porto Velho. Este portal fluvial articulava a localidade com as amplitudes da bacia hidrográfica. A estratégia do sítio surpreende. Permeia o

universo continental e os horizontes marinhos. E responde ao nível tecnológico dos meios de transporte para as circulações do habitat. Não é tarefa fácil para canoas a remo, a partir da posição do Porto Velho, continuarem pelo Rio Ribeira, romper seu estuário, geralmente em condições adversas, navegar um trecho de mar aberto, romper novamente a Barra de Icapara ${ }^{10}$, outro duelo, para enfim alcançar o sítio de Icapara ou de Iguape, quando este, especialmente, está tão próximo do ponto inicial dessa jornada. As vivências interativas do habitat, pregressas e coloniais, delinearam naturalmente este vetor de ocupação por terra. A objetividade da Rua Direita de Iguape retrata isso. A demanda pela ligação foi progressiva no colonialismo. De tão pronunciada, verterá simbolicamente no entalhe do inesperado Valo Grande.

10 "Sobre a navegação pela barra do Icapara, nesse período, é interessante a anotação que, no ano de 1806, fez o coronel João da Costa Ferreira: 'Por esta barra entram algumas lanchinhas, com o bom tempo." (FORTES, 2000, p. 146). 


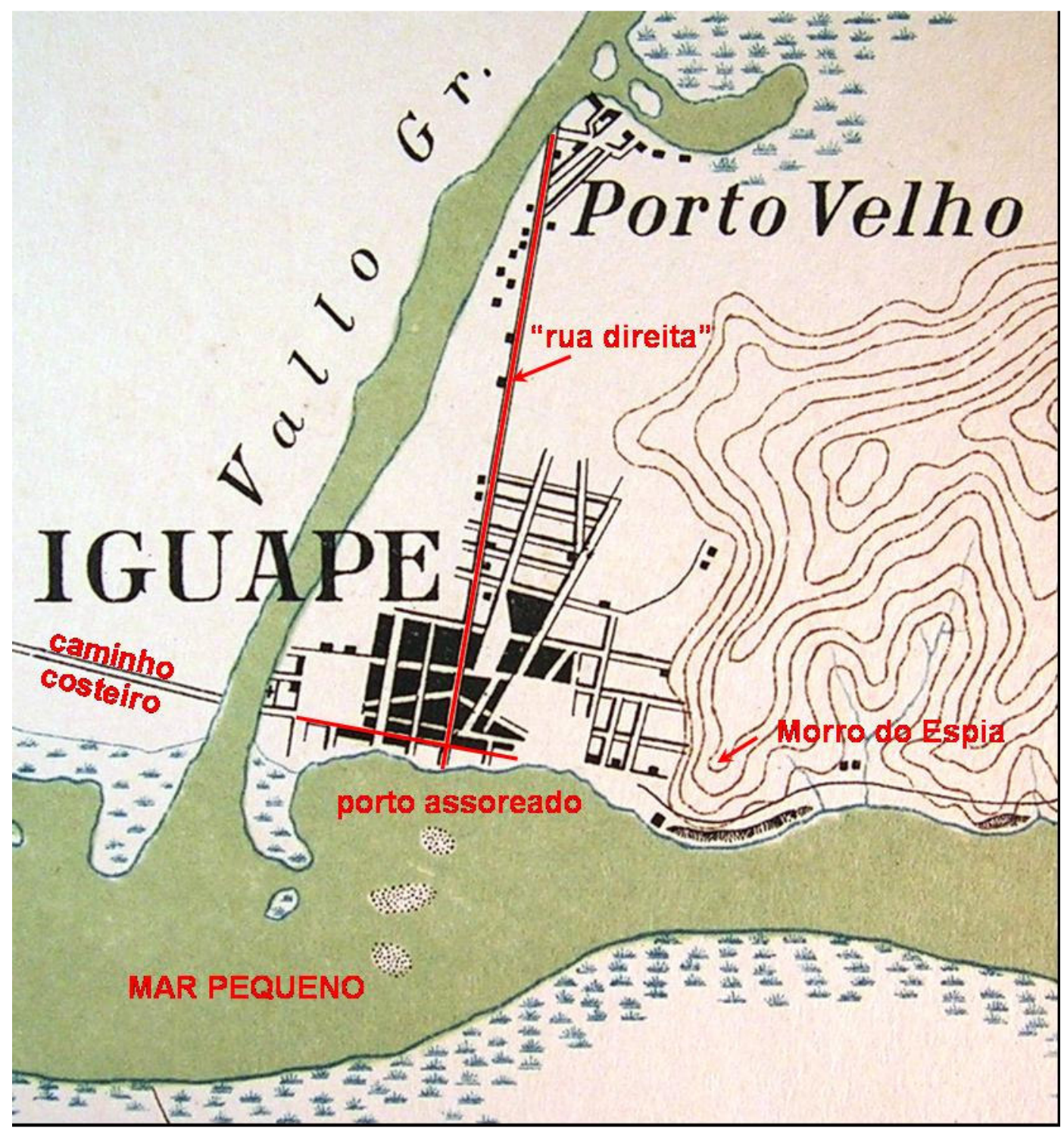

Figura 69. Traços da ocupação. Det. da Planta do Littoral do Estado de São Paulo entre o Saco do Juruvaú e a Barra de Icaparra. CGGESP, 1920. Fonte: Bibl. FAUUSP, LR 918.161 Sa63Ls. Acrescent. textos e sinalizações do autor.

No início do século XIX, a região consolida-se como produtora e exportadora de arroz. O que se pretendia benéfico ao transporte fluvial da produção, evitando-se o transbordo por terra até o porto marítimo, foi causa do seu colapso: o efeito imprevisível da intervenção do homem no complexo e equilibrado sistema hidrológico natural alterou o seu destino. O pretenso estreito canal de ligação do Rio Ribeira com o Mar Pequeno, cujas obras atravessaram dois Impérios, cedeu suas margens de solo arenoso à fúria das águas do rio que encontraram caminho mais 
curto para o desnível natural da marinha. A dragagem progressiva das margens assoreou em poucos anos o porto marítimo natural da Vila, inviabilizando-o para sempre $^{11}$. Iguape já experimentara, no século XVII, outra vivência cíclica efêmera: a do ouro. Algumas minas, nos contrafortes serranos do fundo do vale esgotaram-se rapidamente e deixaram na Vila a primeira casa de fundição da colônia (1630), hoje Museu Municipal.

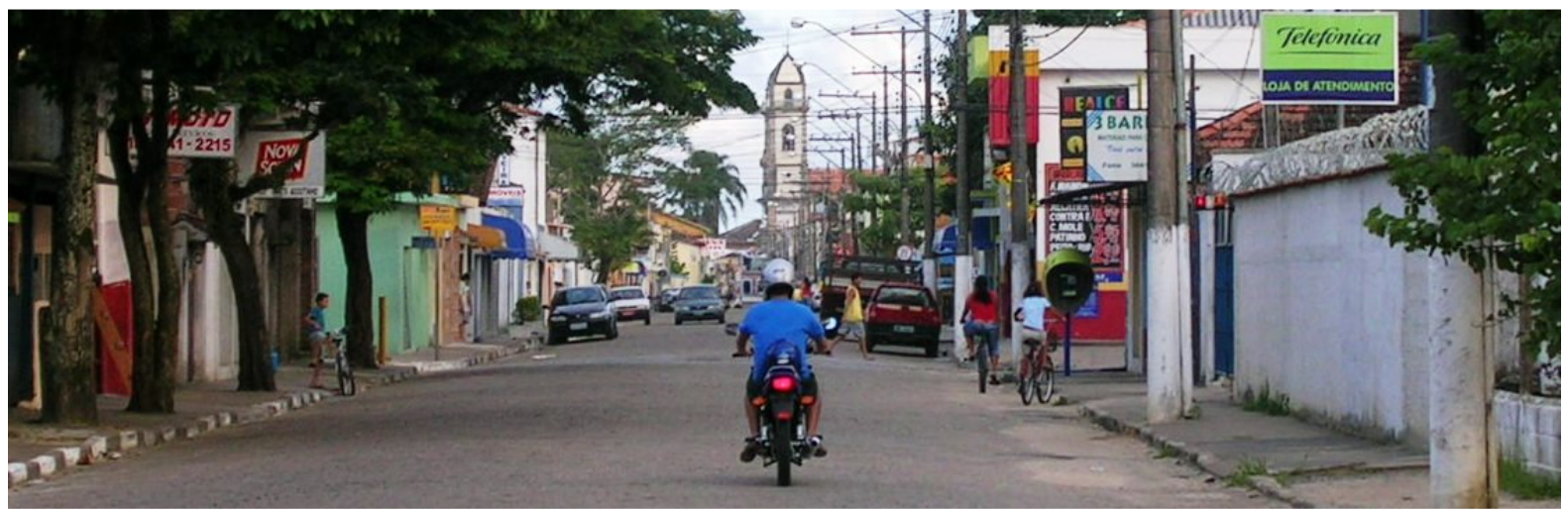

Figura 70. O vertical. No fim da Rua Direita, o principal baricentro de referência visual da cidade, a torre da Basílica de Nossa Senhora das Neves. Foto do autor, 2006.

Linhas cruzadas também simbolizam representações espaciais urbanas. A praça da Matriz de Iguape nos remete ao sagrado vertical e profano horizontal, tão delineado nos núcleos coloniais litorâneos, assentados em áreas planas de beiramar e harmônicos com a paisagem ambiental. Guardiões dos estuários, portais do vasto território que povoou o imaginário dos primeiros colonizadores, sedimentaramse na linha do tempo. Alguns séculos antes da ocupação européia, os mesmos sítios, os mesmos nichos ecológicos, eram lugares de vivência de outros povos que

\footnotetext{
${ }^{11} \mathrm{O}$ nosso Engenheiro Militar esteve na região entre 1805 e 1806 provavelmente em resposta ao ofício da Camara de Iguape que solicita ao Governador Antonio José de França e Horta autorização e verba para abertura do canal. Um ano antes do início das obras, seu parecer será citado em ofício da Câmara de 16 de agosto de 1826: "[...] um habil official da engenharia João da Costa Ferreira; o qual examinando o terreno e attendendo ao futuro perigo que poderia rezultar a Villa [...], declarou que jamais se deveria abrir o Canal pelo Norte, e sim pelo Sul, visto que deste lado poderia ser aberto, sinão com maior ao menos com tanta facilidade em maior distancia da Villa sem perigo e inconveniente algum." (YOUNG, 1902, p. 295).
} 
contribuíram decisivamente para que as sociedades futuras lograssem êxito nos seus destinos.

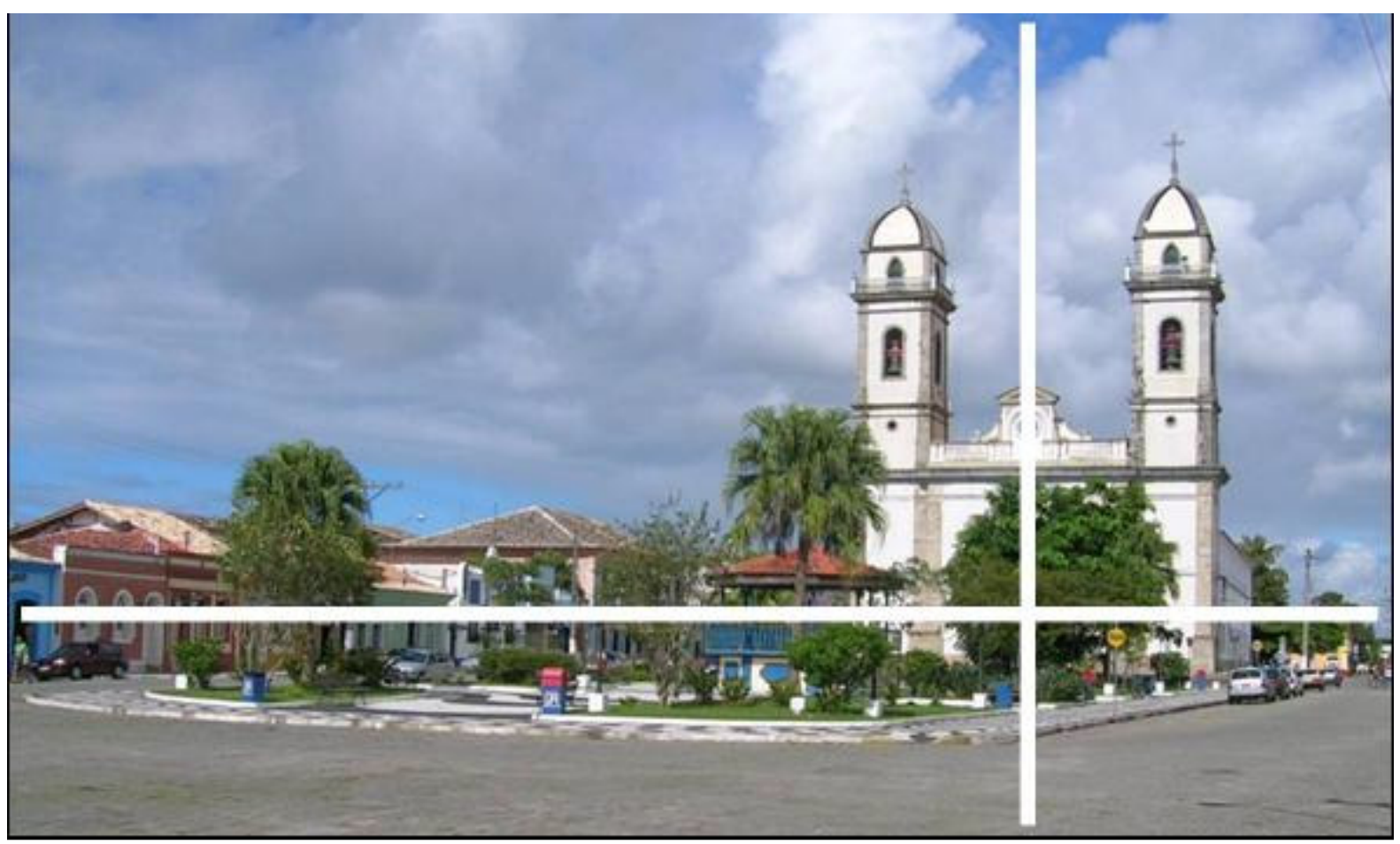

Figura 71. Sagrado \& Profano. Foto e sinalização do autor, 2006.
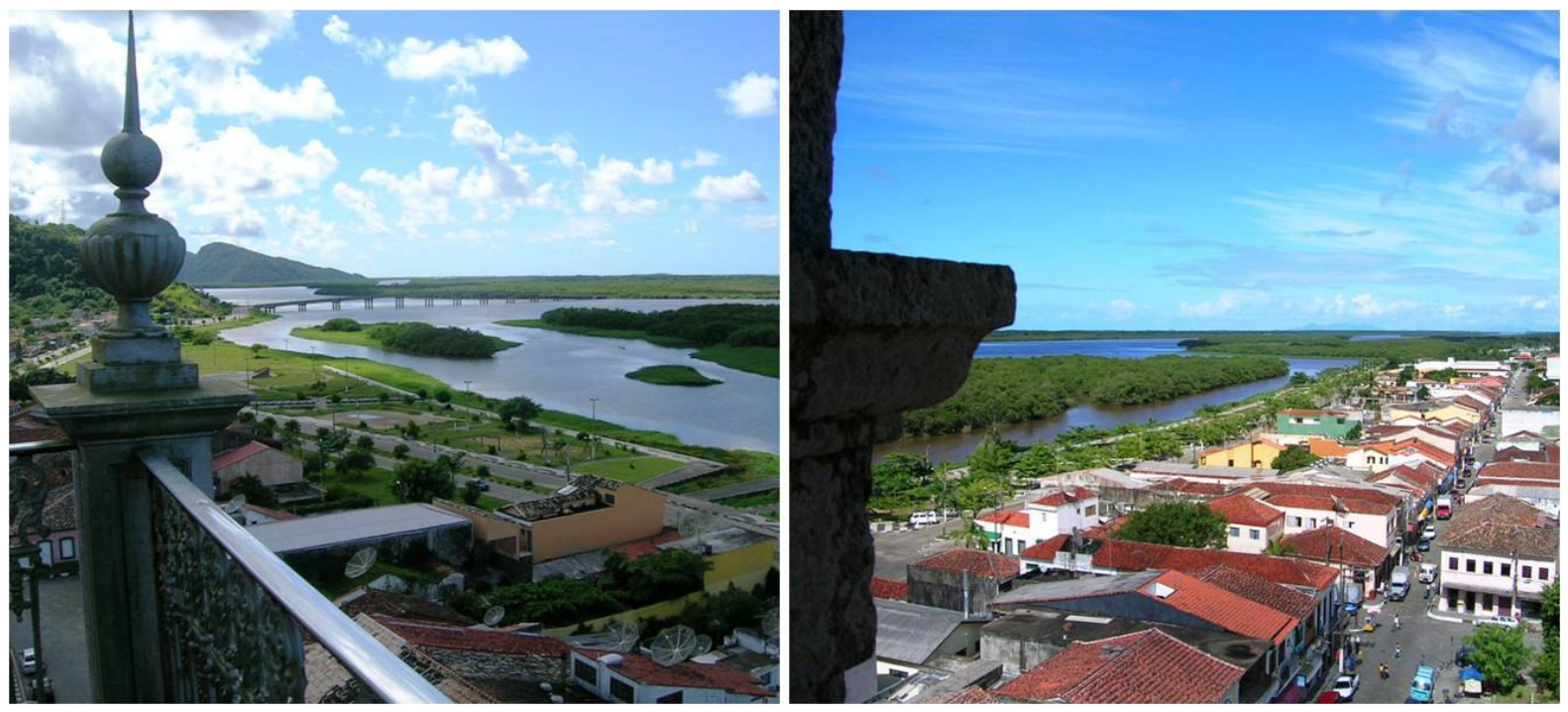

Figura 72. Olhares da torre. Fotos do autor, 2006. 


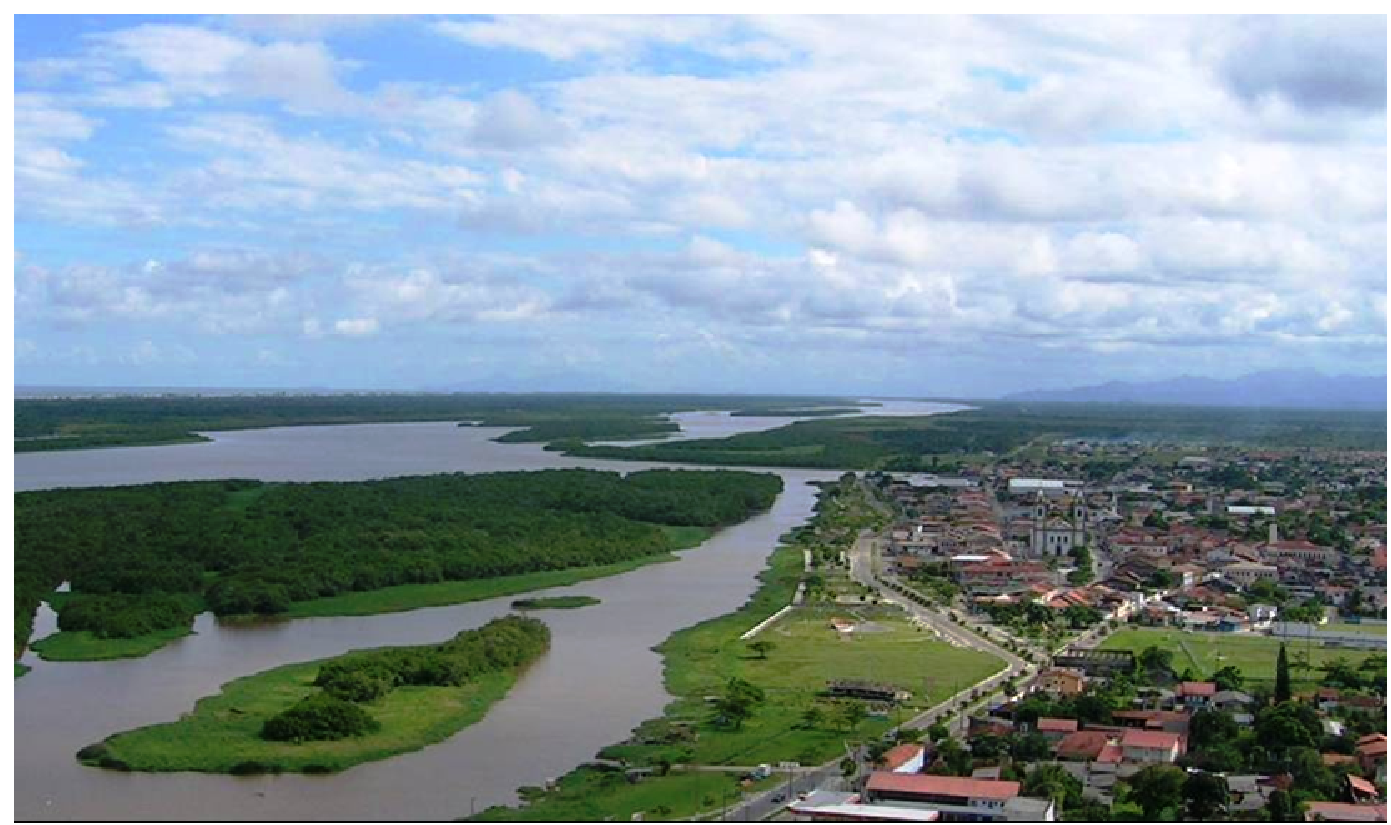

Figura 73. Paisagem das águas. Foto do autor, 2006.

"A cor define alcances perceptivos, modela os espaços com as sensações das formas, expressa os seus desenhos e suas dimensões (...) A cada lugar os tons de sua natureza, a cada lugar os tons de sua cultura. (...)

As cores definem a paisagem, seja na escala próxima do detalhe, seja na distância até atingir a linha do horizonte que é um recorte de duas cores, dois tons desenhando e dimensionando território e atmosfera. (...)

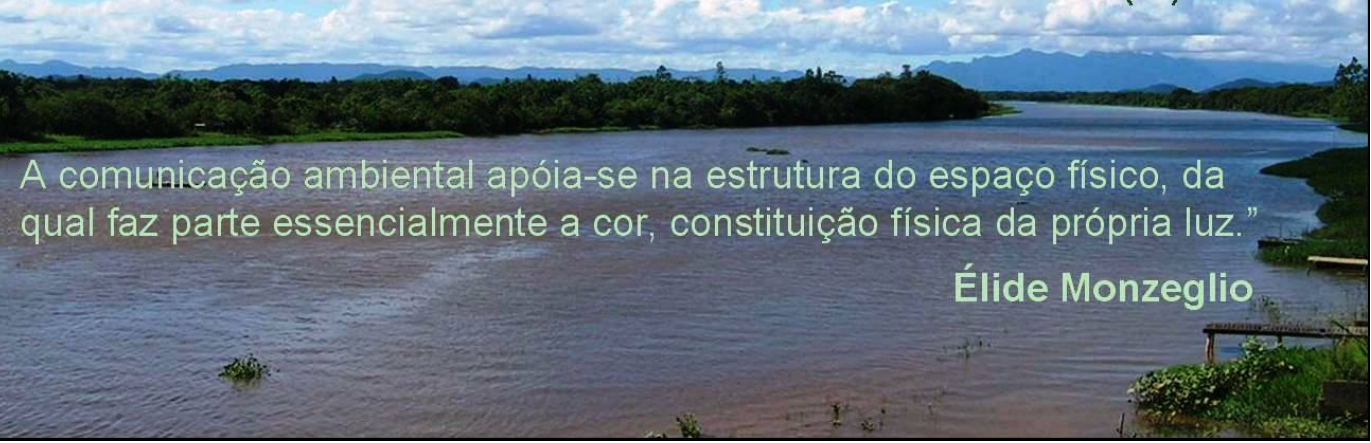

Figura 74. A caminho do mar. As águas serenas do Rio Ribeira de lguape seguem o seu destino. Foto do autor em 3 de abril de 2006. 


\section{7 "S. Sebastiam da Terra firme"}

Quando a ilha de São Sebastião foi batizada Américo Vespúcio estava presente. Possivelmente arribaram na ampla enseada do setor Norte, de onde provinham, e ao adentrarem pelo canal entenderam que se tratava da maior ilha marítima do atual Estado de São Paulo. Era dia 20 de janeiro de 1502. Talvez tenham aportado. Em condições normais não se leva dois dias para chegar em São Vicente, batizada no dia 22 do mesmo mês. Quem sabe os encantos da paisagem e a serenidade portuária motivaram Gonçalo Coelho a lançar âncoras.

Mas quem conheceu bem a localidade de São Sebastião foi Hans Staden. Quando esteve no local pela primeira vez, amargava a certeza que morreria. $\mathrm{Na}$ manhã daquele dia, em meados de janeiro de 1554, foi aprisionado em Bertioga

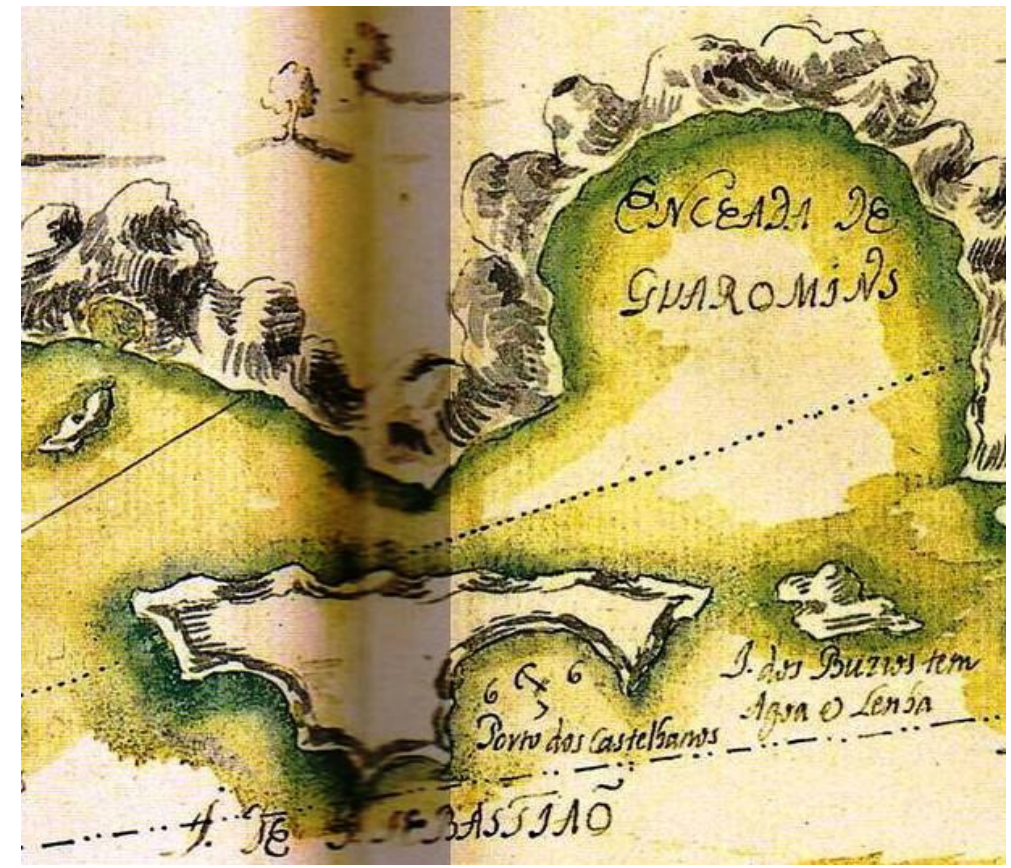
por guerreiros Tupinambás.

Figura 75. A maior ilha. Detalhe da Carta 6 da "Descripção de Todo o Maritimo [...]" mencionada. João Teixeira Albernaz I, Caiu numa cilada 1640. Fonte: MARTINS, 2003. 
imprevisível: não era época de suas incursões guerreiras nesta frente Tupiniquim, habituais nos meses de inverno quando disputavam a piracema dos cardumes de tainhas e paratis que adentravam no estuário vicentino. Levaram-no nas céleres canoas em direção aos seus domínios, localizados na baía de Angra dos Reis. Nessa viagem pernoitaram no acampamento de São Sebastião. Antes aportaram numa das praias da face interna da ilha homônima:

[...] pelas quatro horas da tarde, a julgar pelo sol - se dirigiram para uma ilha e puxaram a canoa para a praia. Aí queriam passar a noite. A mim, arrastaram-me por terra. Eu não podia ver nada porque tinha o rosto machucado, e não podia andar direito por causa das feridas na perna. Por isso precisei deitar-me na praia. Eles rodearam e davam-me a entender, com gestos ameaçantes, como iriam devorarme. (STADEN, 1974, p. 84).

A figura do cronista deveria ser conhecida dos Tupinambás. Era o responsável pela pequena fortaleza que terminou de construir, a serviço da Coroa, na barra de Bertioga, na porção norte da ilha de Santo Amaro. Além de terminar a construção, foi contratado para ali residir na defesa do canal, e talvez por isso tenha sido aprisionado. Suas lágrimas podem ter-Ihe salvado. Conforme observou Darcy Ribeiro, os índios não comiam covardes para não incorporar suas mazelas: "[...] e cantei com os olhos úmidos de lágrimas, do fundo do coração, o salmo: 'Do abismo da miséria clamo eu a Ti'. Ao que disseram os selvagens: 'Vejam como ele grita; agora está desesperado." (STADEN, 1974, p. 84). O prisioneiro deve ter percebido a força dos seus lamentos, pois sempre clamava por vida e por Deus quando as ameaças recrudesciam nos seus nove meses e meio de cativeiro. No final daquela tarde,

Então ponderaram que não seria conveniente passar a noite na ilha e aí acampar e dirigiram-se ao continente em frente. Já era noite, quando chegamos. Lá havia cabanas, que tinham construído antes. Arrastaram as canoas para a terra, fizeram fogo e deitaram-me perto. Devia dormir numa rede, que chamam ini. Estas são seus leitos. (STADEN, 1974, p. 84). 


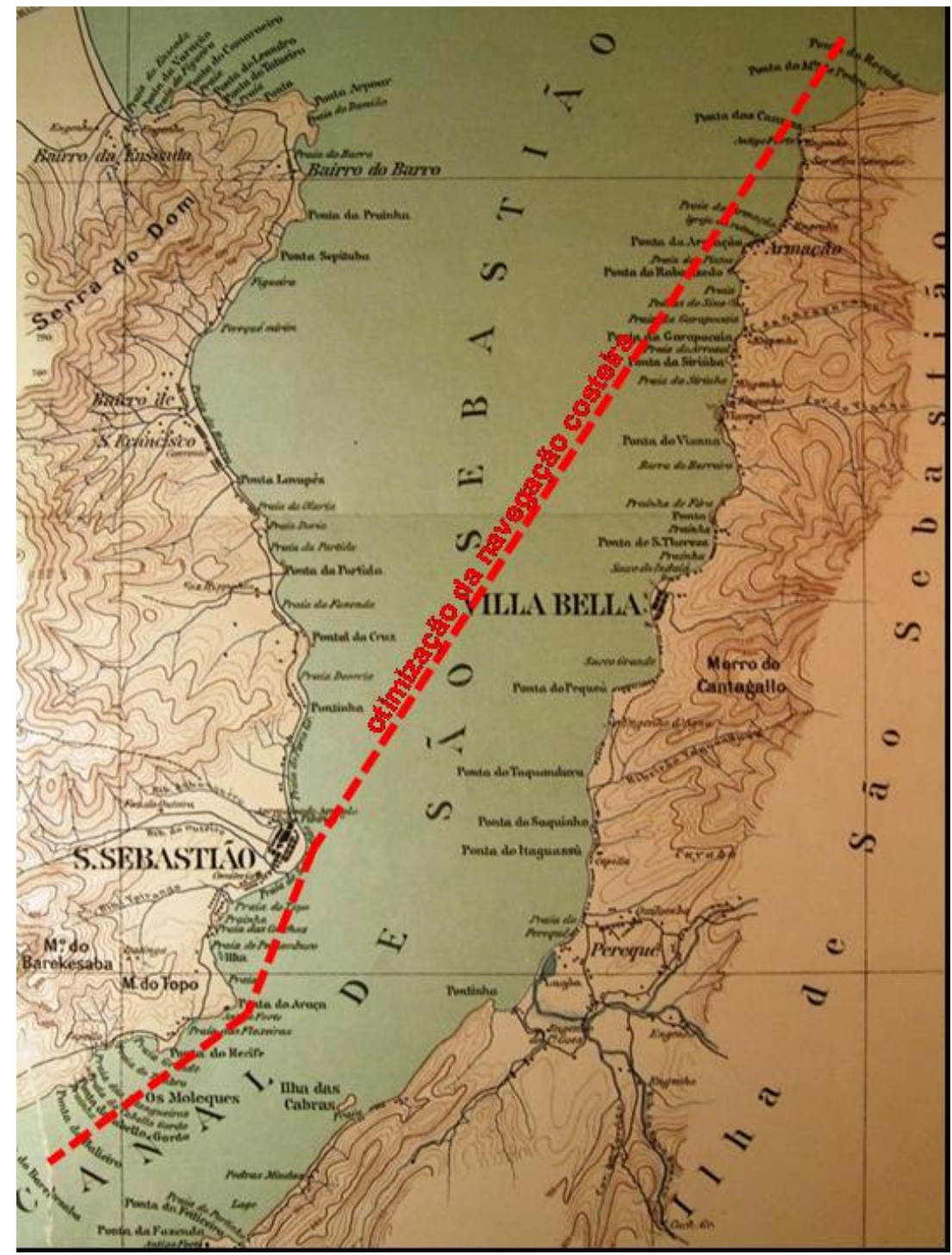

Figura 76. Canoagem. Detalhe da Planta do Litoral de S. Sebastião e do Rio Juqueriquerê. CGGESP, 1915. Fonte: Bibl. FAUUSP, LR 918.161 Sa63j. Acrescentados textos e sinalizações do autor.

Parece bastante provável que o local deste acampamento seja o sítio da futura vila de São Sebastião. Trata-se de uma esplanada praiana que configura uma "ponta continental" onde articulam-se os rumos da navegação costeira e onde o canal tem a menor largura em relação à ilha de São Sebastião. É pronunciado também na Carta 6 de Albernaz (Figura 75, p. 148). Este "acampamento" indígena temporário, dotado de água potável, pode ter sido embrionário dos sítios e caminhos de ocupação entre o continente e a ilha, pelo menor percurso de marinha. Considere-se ainda que na frente insular, outra área com atrativos de planície 
polariza com a localidade continental (Figura 76). Alguns morros no setor sul protegem o sítio das ventanias desse quadrante. Talvez por isso, naquele fim de tarde, os guerreiros tamoios buscaram melhor abrigo atravessando o canal, onde

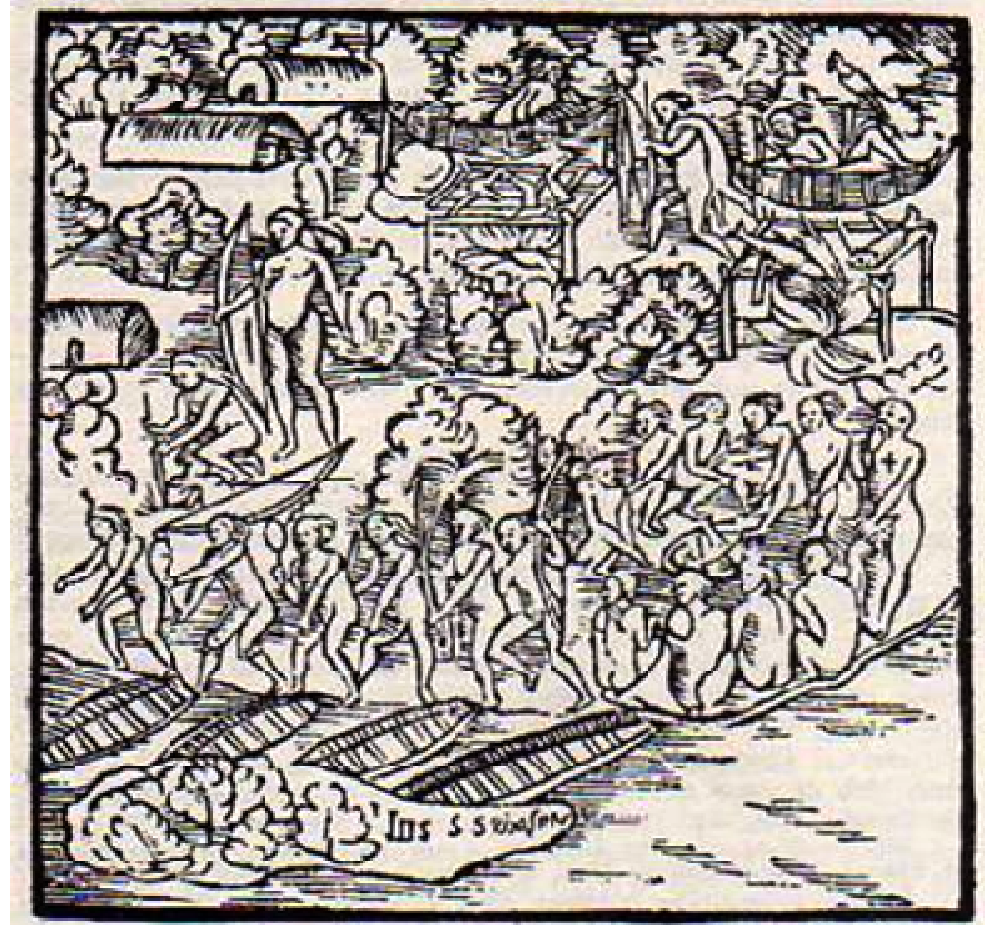

25. - Acompamento de tupinambds an proxinidodes de the de Sto Sebestifo. Ve-se Hans Steden de pe, assihalede cem una cruz.

Figura 77. Acampamento. Note-se a conformação da praia na xilogravura. Fonte: STADEN, 1974, p. 126. havia cabanas. A sede do atual município ocupa generosa planície costeira, a de maior amplitude nas adjacências, onde a serra do Mar debruça abruptamente no oceano. São condições ambientais atrativas às concentrações sociais, de qualquer período. O local beneficia-se de regatos de água doce, provenientes da encosta da Serra do Mar, e o canal que separa a ilha do continente, pleno de águas calmas, tem profundidade suficiente para destinar-se a um grande porto.

A escolha de sítios praianos para acampamento é bastante aceitável pela temporalidade da ocupação e facilidade na puxada das canoas, permitindo-se diferenciar dos locais elevados que os Tupinambás escolhiam para permanência das aldeias, estrategicamente mais protegidos. Nestes eventos passageiros, é bem provável que acampassem nas planícies adjacentes aos portos das canoas, envolvidos com a pesca e o preparo dos alimentos. A ilustração acima, da publicação original do livro de Staden, sugere o acampamento em sítio plano, 
reiterado pela narrativa: "Arrastaram as canoas para a terra, fizeram fogo e deitaramme perto". (STADEN, 1974, p. 84). Os acampamentos de São Sebastião e de Ubatuba eram representações dos meios ofensivos Tupinambás, fronteiras espaciais e logísticas de suas áreas de ocupação, conforme texto de Neme e Beltrão mencionado na página 63 desse trabalho.

No mapa de Albernaz abaixo a vila ainda não está assinalada. Não podemos precisar o período do seu levantamento, aquarelado em 1640. A povoação, iniciada no início do século por colonos de Santos requerentes de sesmarias na região, foi elevada a Vila em 1536. Atestando a ocupação embrionária, Frei Gaspar Madre de Deus informa:

[...] e por isso começa da maneira seguinte o auto da criação desta Vila: "Anno do Nascimento de Nosso Senhor Jezus Christo de mil seis centos trinta seis annos aos desaseis dias do mez de Março do dito anno nesta povoaçam de S. Sebastiam da Terra firme, Termo, e Jurisdiçam da Villa de Santos da Capitania de S. Vicente..." (MADRE DE DEUS, 1975, p. 182, grifo nosso).

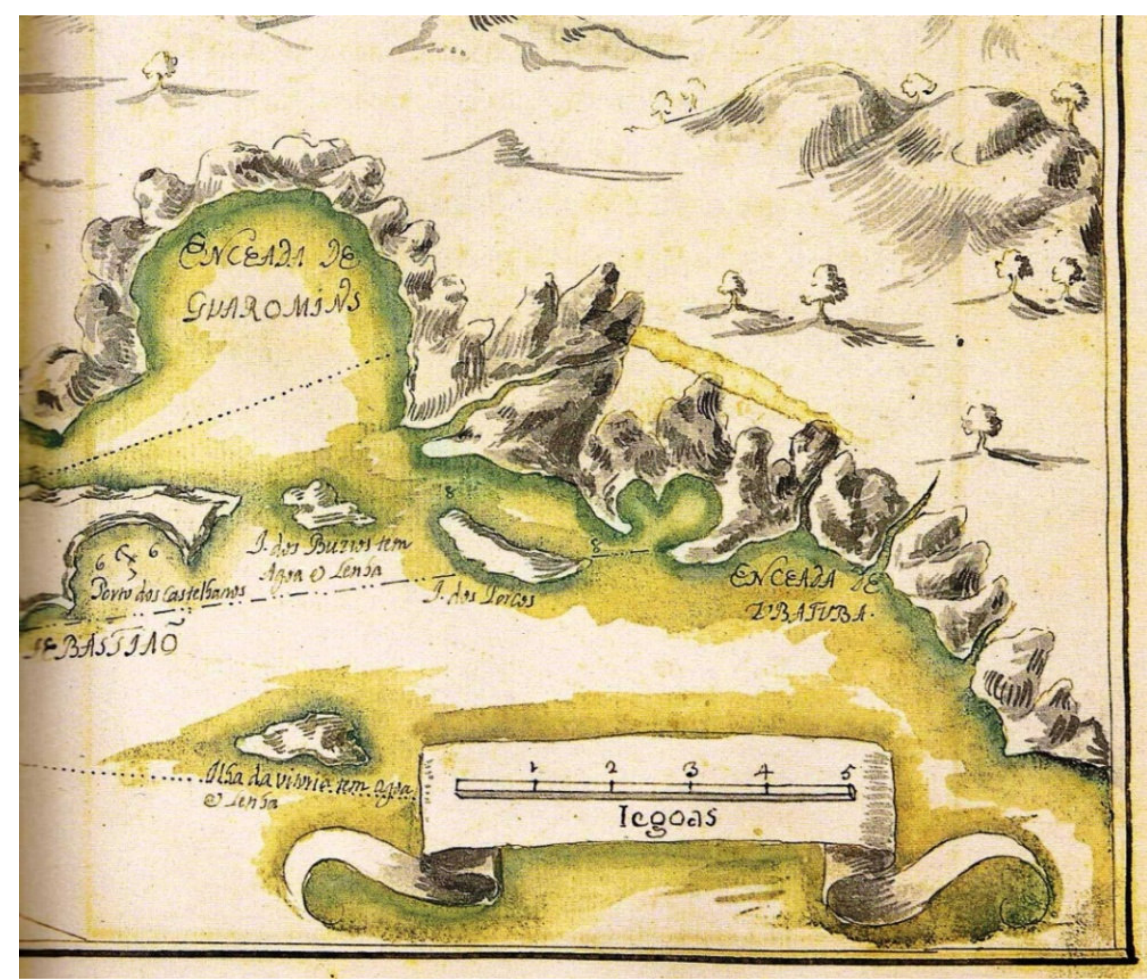

Figura 78. Terras desabitadas. Detalhe da Carta 6 da "Descripção de Todo o Maritimo [...]" mencionada. João Teixeira Albernaz I, 1640. Fonte: MARTINS, 2003. 
No início do século XVII, uma carta de sesmaria de 20 de janeiro de 1603 afirma que: "na terra firme defronte dela [Ilha de São Sebastião] e toda a costa até o Rio de Janeiro eram todas as terras desabitadas e devolutas”. (CAMPOS, pág. 68, 2000). Nesse começo de século inicia-se o povoamento do Litoral Norte com a instalação de engenhos de açúcar. Em outra carta de sesmaria, de 27 de maio de 1640, "Os sesmeiros afirmam ser moradores em São Sebastião, cujo povoado fora elevado a vila em 1636, dizendo que 'queriam fazer um engenho de fazer açúcar, nas cabeceiras de Juqueriquerê [...]." (CAMPOS, 2000, p. 70). Em Ubatuba, também foram requeridas sesmarias contemporâneas para o plantio da cana-de-açúcar. (OLIVEIRA, 1977, p.42).

Estas duas cidades do Litoral Norte paulista selaram identidades comuns que remontam às ocupações Tupinambás. O seqüenciamento colonial é revelador do encadeamento espacial não só dos sítios urbanos, mas do contexto regional. As vilas foram fundadas com o mesmo propósito: resultaram da ocupação de um "vazio" litorâneo, da mesma forma que os Tamoios, com as "marcas territoriais" representadas pelos acampamentos, asseguravam a amplitude do habitat $^{12}$. Suas

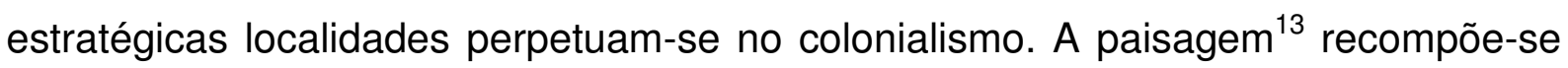
após o encontro cultural entre europeus e indígenas. Resgata seus atrativos, seus "nichos ecológicos", suas articulações continentais e seus portos marítimos.

É notável a utilização de canoas no Litoral Norte para circulação de pessoas e mercadorias, principalmente na ligação com Santos, até o início do século XX!

\footnotetext{
12 "E é significativo que a colonização portuguesa não se tenha firmado ou prosperado muito fora das regiões antes povoadas pelos indígenas da língua-geral. Estes, dir-se-ia, que apenas prepararam terreno para a conquista lusitana. Onde a expansão dos Tupi sofria um hiato, interrompia-se também a colonização branca [...]" (HOLANDA, 1971, p. 72).

13 "A superfície da Terra é elaborada para cada pessoa pela refração por meio de lentes culturais e pessoais, de costumes e fantasias. Todos nós somos artistas e arquitetos de paisagens, criando ordem e organizando espaços, tempo e casualidade, de acordo com nossas percepções e predileções." (MACHADO, 1986, p. 97). Também citado na página 2 desse trabalho.
} 

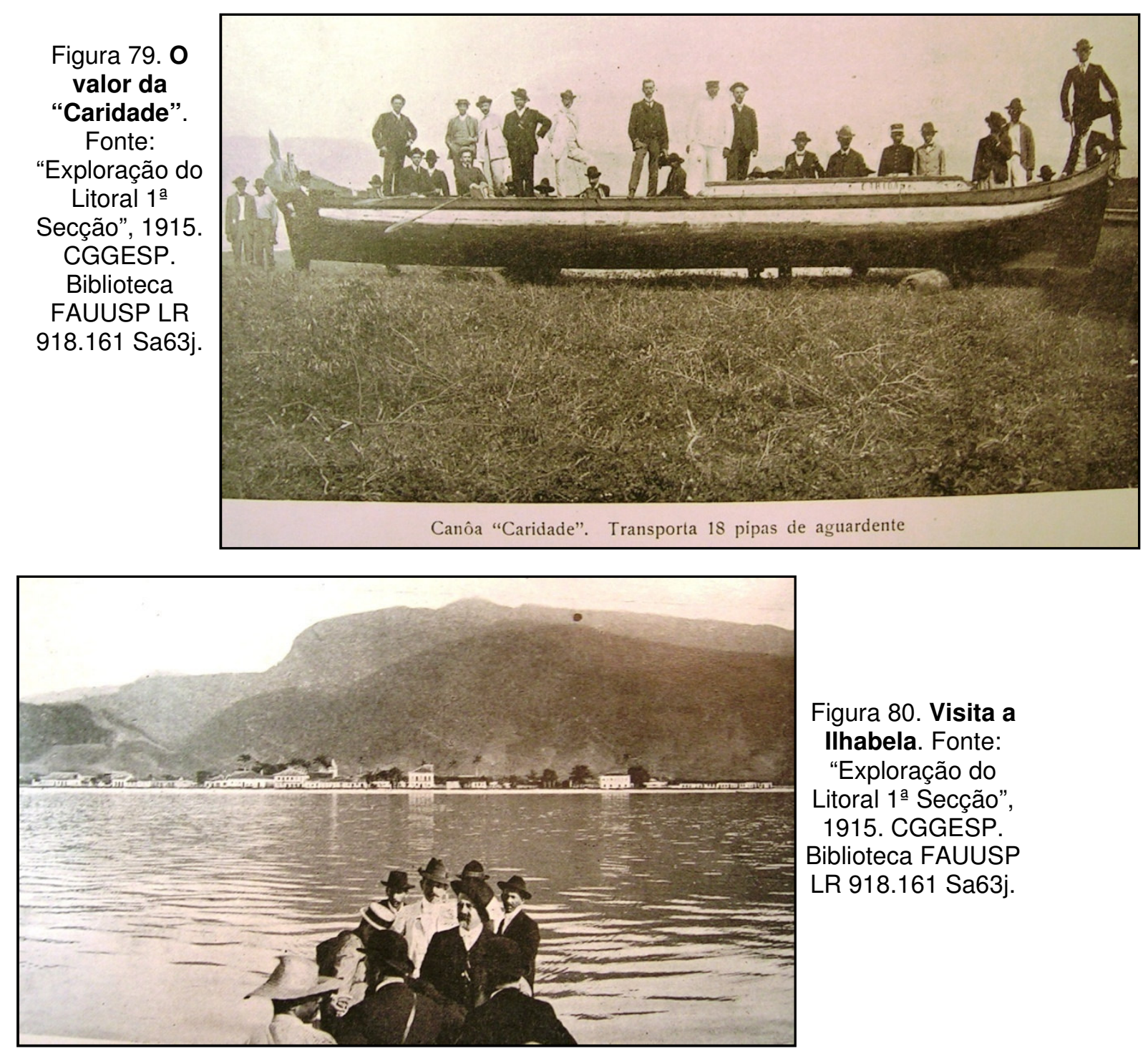

Figura 80. Visita a

Ilhabela. Fonte:

"Exploração do

Litoral 1 Secção", 1915. CGGESP.

Biblioteca FAUUSP

LR 918.161 Sa63j.

Figura 81. Águas serenas. Fonte: "Exploração do Litoral 1 a Secção", 1915.

Com.Geog.Geol.ES

P. Biblioteca

FAUUSP LR 918.161 Sa63j.

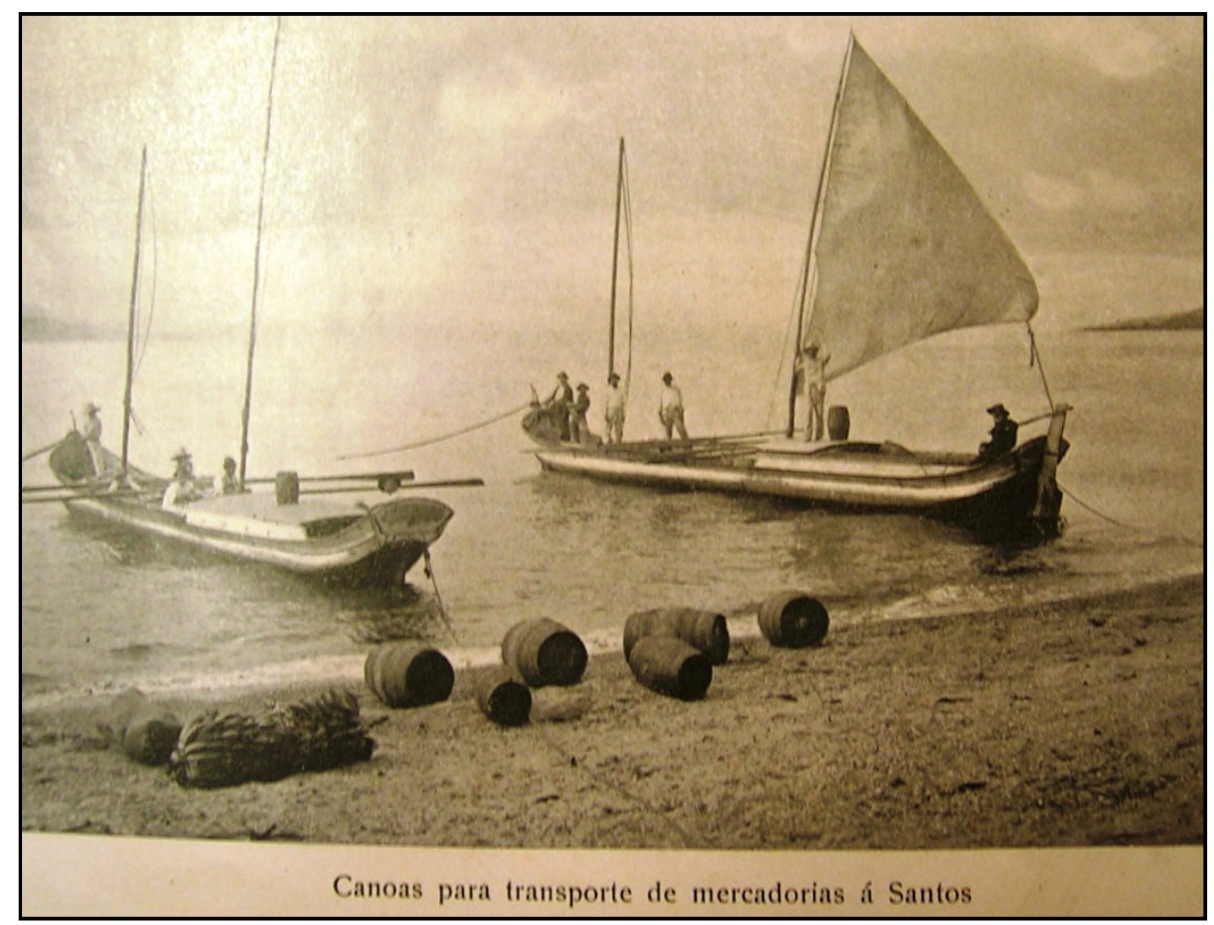




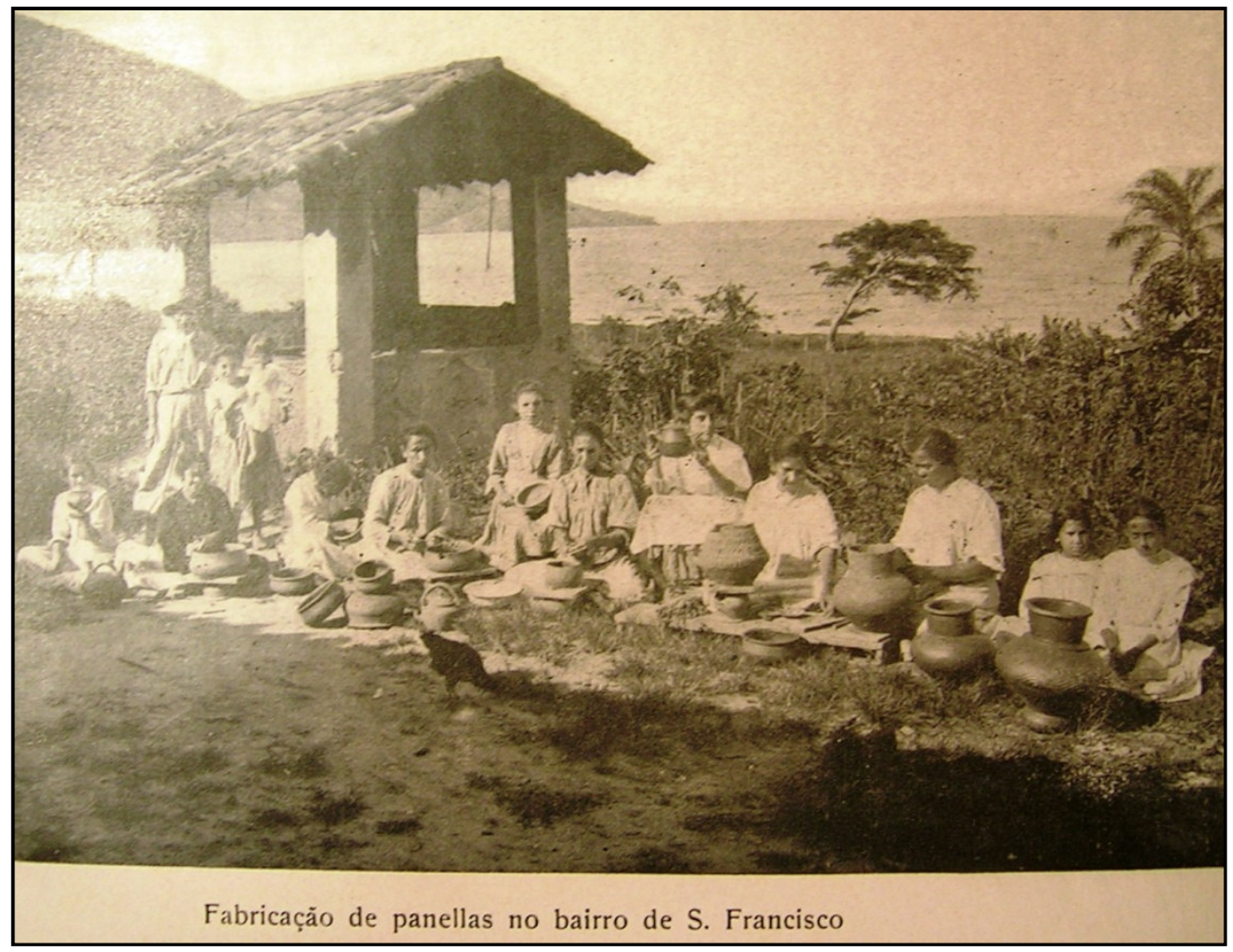

Figura 82. Velhos hábitos. Fonte: "Exploração do Litoral 1 Secção", 1915. CGGESP. Bibl. FAUUSP LR 918.161 Sa63j.

A Figura 83 da página seguinte é a Carta de São Sebastião do levantamento que João da Costa Ferreira e Antonio Rodrigues Montesinhos elaboraram de toda a costa da Capitania de São Paulo, no início da década de 90 do século XVIII. É notável a condição de "pontal" do sítio em relação ao canal fronteiro, acentuado pelo arco inferior do desenho que limita o núcleo. Não parece distante da representação espacial da xilogravura "[...] aberta indubitavelmente sob sua [Staden] orientação [...]" (STADEN, 1557, p. 18), mostrada na Figura 77 da página 151. O levantamento identifica um dos córregos daquele espraiado praiano. Estas fontes de água doce eram componentes ambientais fundamentais ao sucesso dos acampamentos indígenas, das aldeias, e dos núcleos coloniais subseqüentes. Estão presentes em todas as vilas estudadas, muitas vezes vetorizando traçados urbanos, como em Cananéia e Santos. 


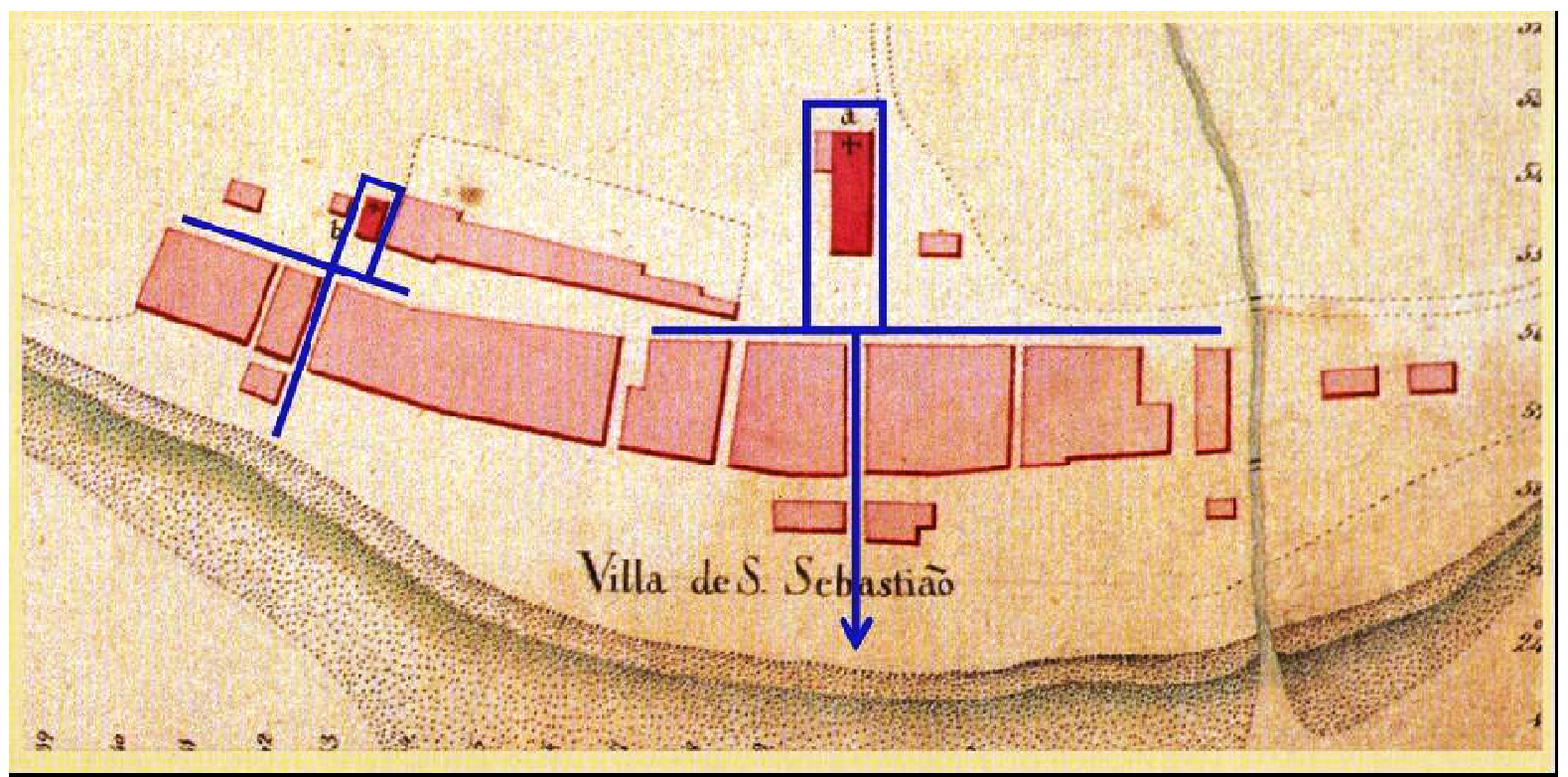

Figura 83. A Vila no pontal. Detalhe de uma das "Cartas Corographicas e Hydrographicas...", de João da Costa Ferreira, 1815. Fonte: REIS FILHO, 2001, p. 202. Acrescent. sinalizações do autor.

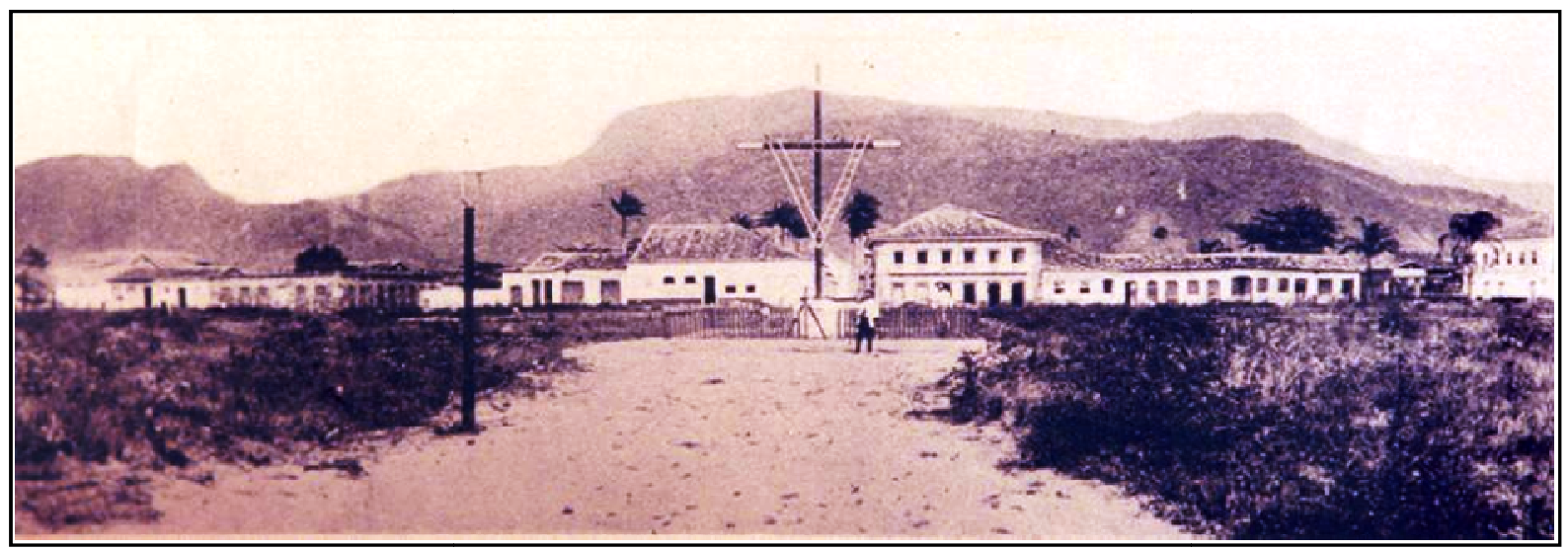

Figura 84. 0 núcleo de beira-mar. Sem data. Fonte: Prefeitura Municipal de São Sebastião

São Sebastião, da mesma forma que Ubatuba, volta-se para o portal do mar. Ambas, todavia, parecem resguardar seus núcleos sociais, as praças, com relativo afastamento da orla. Devemos pensar na vulnerabilidade destas vilas, no seu relativo isolamento, sem instalações militares de apoio. A concavidade marinha molda o arco de implantação do casario frontal, adequando a vocação portuária com a diretriz ambiental. Não deixa de revelar um desenho defensivo. A regularidade ortogonal, todavia, está presente nos módulos do binômio adro-igreja e projeta-se em cruz nos alinhamentos adjacentes. Esta imagem temporal do núcleo urbano de 
São Sebastião é bastante reveladora deste conceito, também verificado nas outras cidades estudadas. Os módulos germinais dos núcleos, atrelados ao(s) edifício(s) religioso(s), irradiam sua ortogonalidade na expansão urbana, até que os traçados sejam inexoravelmente tencionados pelas particularidades ambientais do tecido. Estas induzem a descontinuidade dos alinhamentos embrionários, relativizando a regularidade e, muitas vezes, a contigüidade prismática dos edifícios. É quando, nos dizeres de Sérgio Buarque, a "[...] sua silhueta se enlaça na linha da paisagem." (HOLANDA, 1971, p. 76). O ambiente suplanta os rigores da geometria e os desenhos dos núcleos coloniais revelam outra racionalidade: a adequação da arquitetura urbana aos seus sítios.

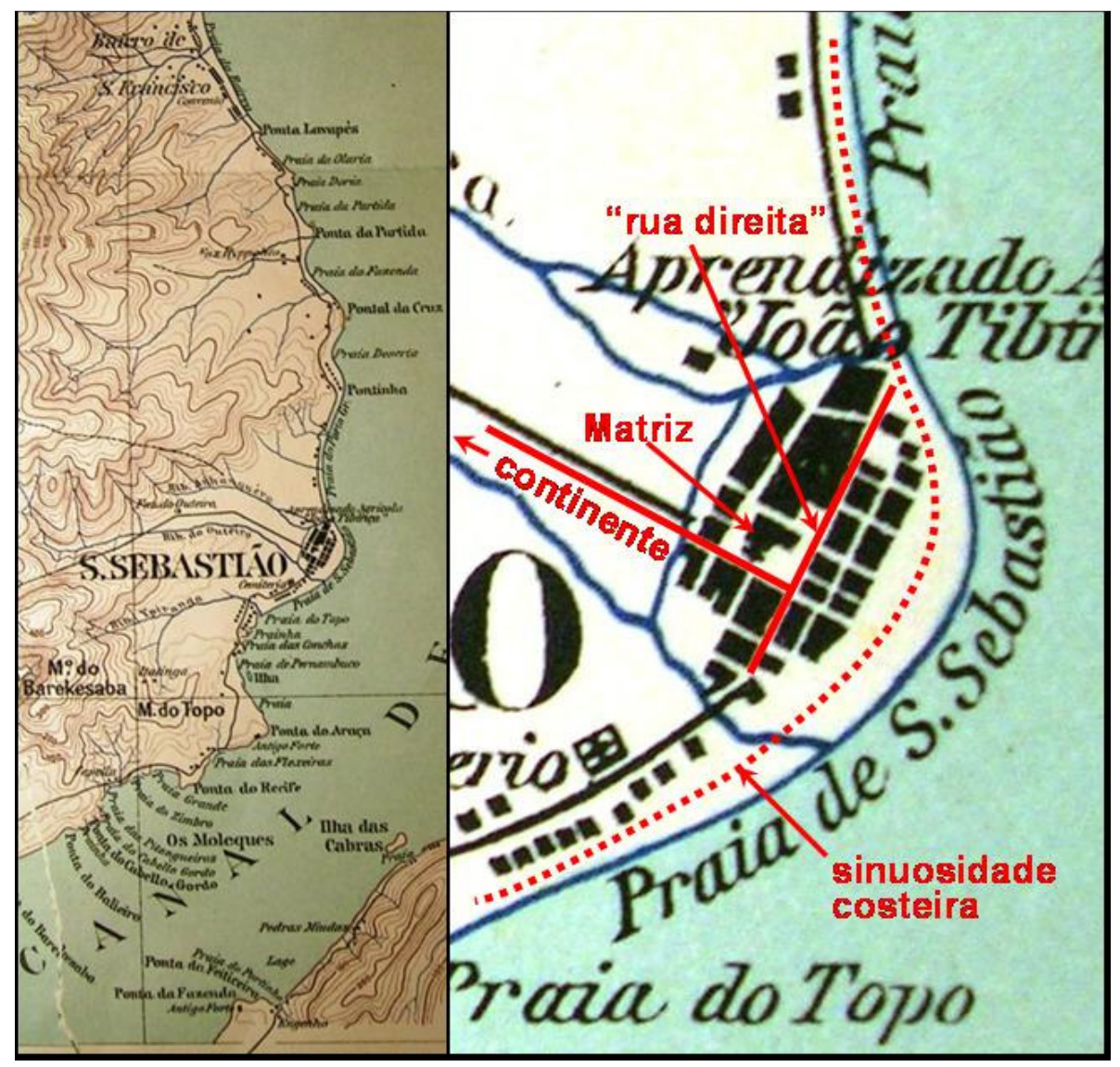

Figura 85. Articulações. Detalhe da Planta do Litoral de S. Sebastião e do Rio Juqueriquerê. CGGESP, 1915. Fonte: Bibl. FAUUSP, LR 918.161 Sa63j. Acresc. textos e sinalizações do autor. 
O alinhamento da costa é a principal diretriz de ocupação setorial de São Sebastião. Sua mais significativa planície costeira, aliás, de toda a região, localiza-se destacada ao Norte da Vila. É a porção continental da grande Enceada de Guaromins assinalada por Albernaz, bacia hidrográfica do Rio Juqueriquerê. Entre esta zona plana e outras de menor escala intercaladas na direção Sul, a Serra do Mar debruça seus contrafortes na borda oceânica com poucas tréguas para ocupações humanas. Uma delas é o sítio da Vila. Neste trecho a imposição do relevo induz a circulação por praias e promontórios da borda marinha, e valoriza a navegação costeira. É o que se verifica na Figura 76, p. 150. Decerto esta diretriz "atravessa" a Vila na sua componente "rua direita", vetor de sua expansão urbana (segunda situação da Nota 4, p. 112). A articulação continental de São Sebastião é secundária. Trata-se de uma particularização em relação às outras Vilas estudadas que pode ser abstraída no desenho continental da Figura 88, página 161. Não é por terra, em diretriz perpendicular, a ligação mais adequada da localidade com os atrativos regionais da bacia do Paraíba ou mesmo do Alto Tietê.

O Arquiteto Murillo Marx vê regularidade em São Sebastião: "As fundações brasileiras que apresentam inegável regularidade, como João Pessoa, São Cristóvão, Itu ou São Sebastião, nem sempre constituem planos em xadrez [...]." (MARX, 1991, p. 61). Mas outra reflexão do autor, universal sobre os nossos aglomerados, é mais significativa:

O local da igreja matriz, ou da nova matriz, será o mesmo - aquele ponto geograficamente destacado de quando se iniciou um ajuntamento de moradas; aquele terreno então generosamente amplo que, sempre que possível, exibia de todos os lados a capelinha original, que possibilitava o seu contorno quando das procissões; aquele setor da povoação privilegiado pela concentração de gente, de atividades e de negócios que a proximidade do templo estimulava. A presença, diante do edifício religioso, de um espaço aberto, de seu adro, palco de tantos e tão variados agrupamentos, objeto de carinho e do gasto maior da comunidade, conservado, ampliado e composto sempre com mais empenho e capricho, 
alcançará também outra dignidade e expressão. O mesmo espaço aberto, a mesma articulação, todavia, ou seja, o ponto focal, institucional e espacial permanecerá o mesmo num outro estágio de evolução social e institucional, que reflete - o que realmente importa - uma outra etapa da evolução urbana da localidade. (MARX, 1991, p. 27).

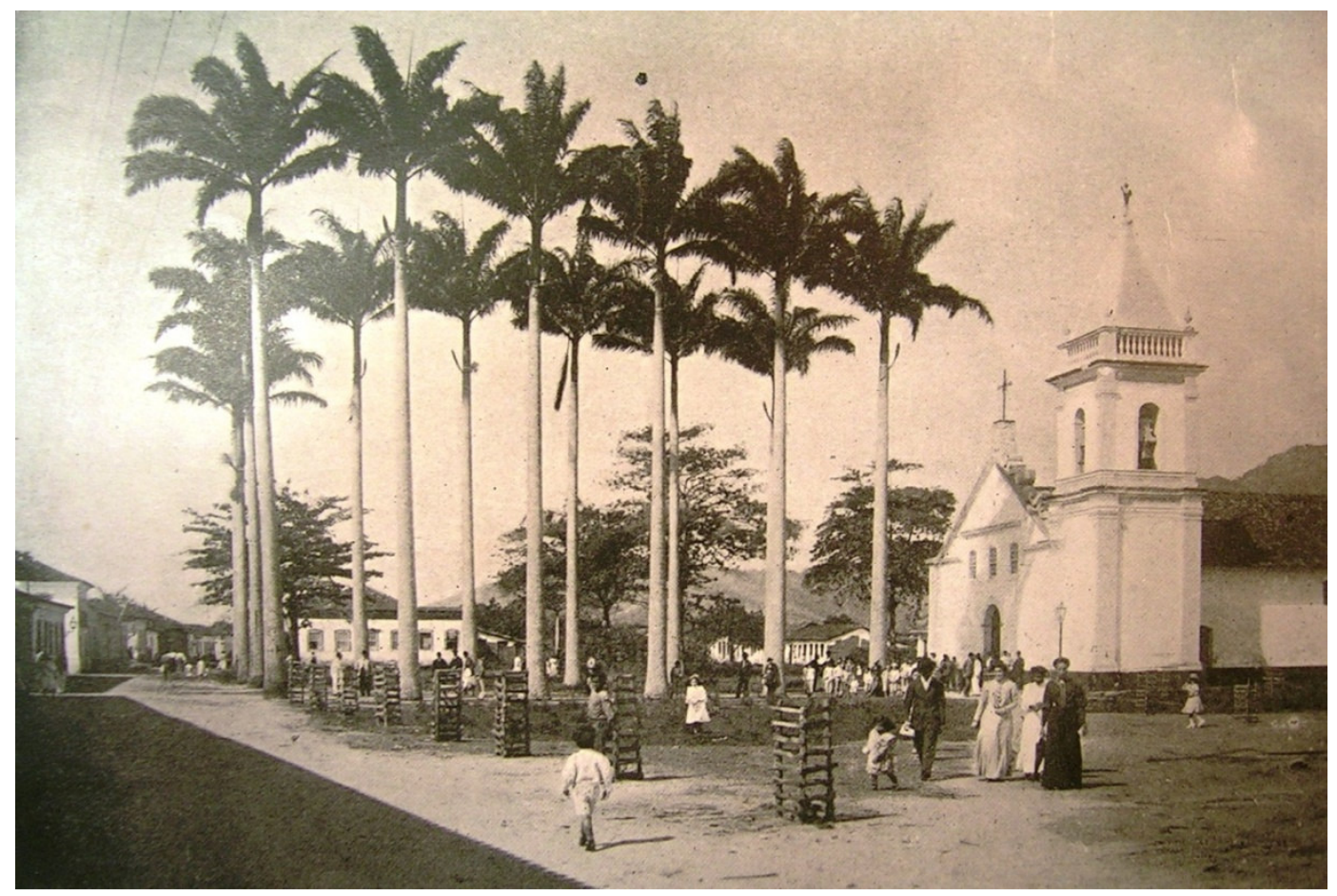

Figura 86. "O local da Matriz". Fonte: "Exploração do Litoral 1aㅗ Secção", 1915. CGGESP. Bibl. FAUUSP LR 918.161 Sa63j.

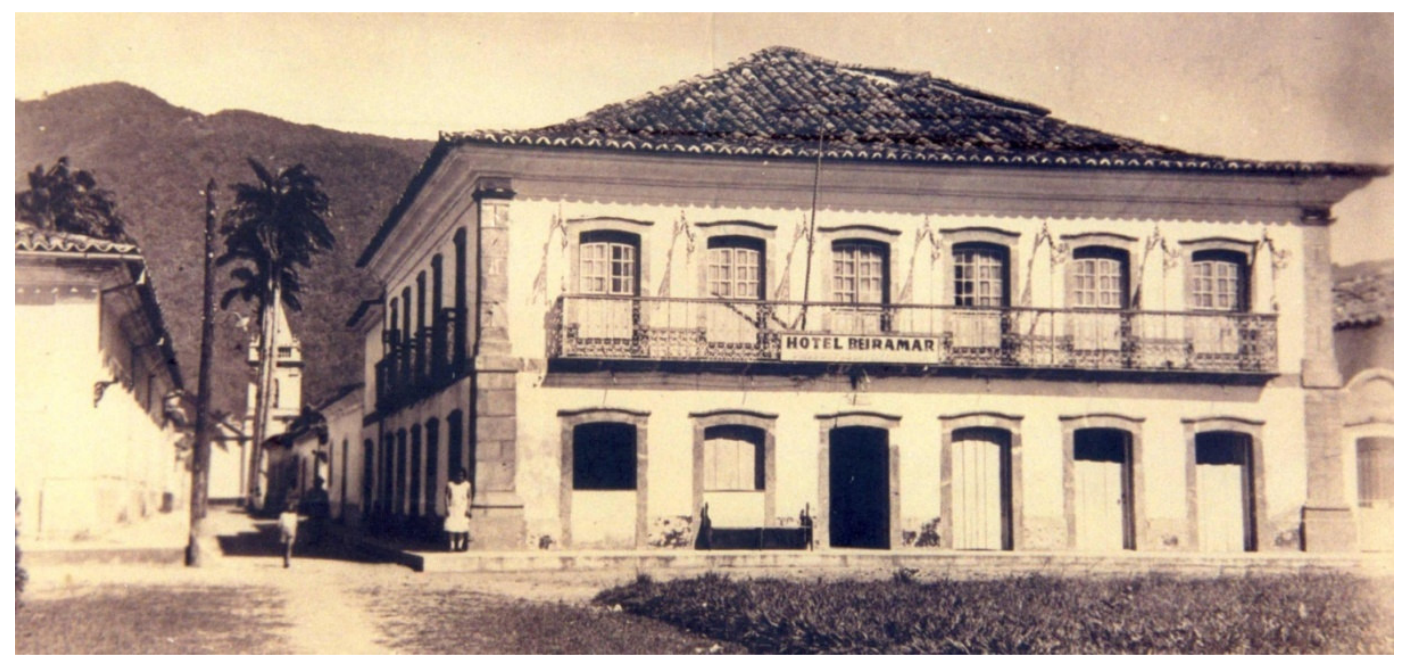

Figura 87. Baricentro. O referencial visual da torre no alinhamento do mar e a imponente futura Casa Esperança com estilemas neoclássicos.

Fonte: Prefeitura Municipal de São Sebastião, sem data. 
A Enceada de Guaromins, registrada por João Teicxeira Albernaz I em 1640 (Figura 78, p 152), acolherá anos depois (1665), a "Vila de Santo Antônio de Caraguatatuba". O grupo indígena Gueromimis ocupou a região "Desde o final dos Quinhentos [...] emigrados do alto Tietê [...]." (CAMPOS, 2000, p. 68). Era um dos povos remanescentes do grupo lingüístico Gê, predominantemente "caçadorescoletores", que ainda se defendiam nos territórios de predomínio Tupi. Esta migração provavelmente sucedeu à desestruturação dos Tamoios, quando esta frente litorânea ficou disponibilizada. Ao mesmo tempo, teriam deixado o planalto, "[...] região onde logo se instalaria a Vila de Santa Ana de Mogi Mirim, hoje Mogi das Cruzes [...]" pela pressão do "[...] estabelecimento dos colonos com suas fazendas [...]". (CAMPOS, 2000, p. 47). Terminaram escravizados pelo colonialismo ou "reduzidos" em aldeias jesuíticas no século XVII. Enquanto São Sebastião e Ubatuba foram acampamentos ou "marcas territoriais" dos Tamoios, de acordo com testemunho de Staden, sendo que em Ubatuba instalaram-se aldeias, de acordo com Anchieta, não podemos afirmar o mesmo sobre Caraguatatuba. Apesar de não haver registro documental sobre a presença Tupinambá, a localidade enquadrava-se no seu contexto territorial. Sua condição geográfica favorecia a articulação com o planalto pelo "anfiteatro" da planície costeira. Isto proporciona vertentes de maior extensão nos contrafortes serranos, com menores declividades. Ainda, está na diretriz de Paraibuna, onde os rios Paraibuna e Paraitinga juntam-se para formar o Paraíba, estratégicos à circulação e domínio de suas bacias (Figura 88, p. 161). É razoável supor que este setor ainda não estava no arco de expansão demográfica dos Tupinambás, concentrados no Rio de Janeiro. Mesmo as aldeias de Ubatuba, mais ao Norte, eram recentes e discretas na segunda metade do século XVI. Enquanto acampamento de apoio às viagens guerreiras, a localidade era afastada 
do rumo das navegações, desfavorecendo sua escolha, ao contrário de Ubatuba e São Sebastião. A Enceada de Guaromins insere um recorte pronunciado no limite costeiro, e isola o sítio da futura vila daquelas vivências. Outra observação relativa à sua condição marinha diferencia o destino do seu núcleo colonial: a pouca profundidade de toda enseada inviabiliza a condição portuária. Assim, será inexoravelmente atrelada a São Sebastião. Embora sem esse atrativo, a articulação com o planalto, a significativa planície costeira e o "nicho ecológico" do sítio, com o mesmo perfil dos demais núcleos litorâneos, contribuirão para o desenvolvimento do povoado e posterior fundação da Vila de Santo Antonio de Caraguatatuba em 1665, até que, no final do mesmo século, uma epidemia de varíola deixa-a deserta. Só na segunda metade do século seguinte será revitalizada sob os interesses de D. Luiz Antônio de Souza Botelho Mourão, o Morgado de Mateus. (CAMPOS, 2000, p. 80).

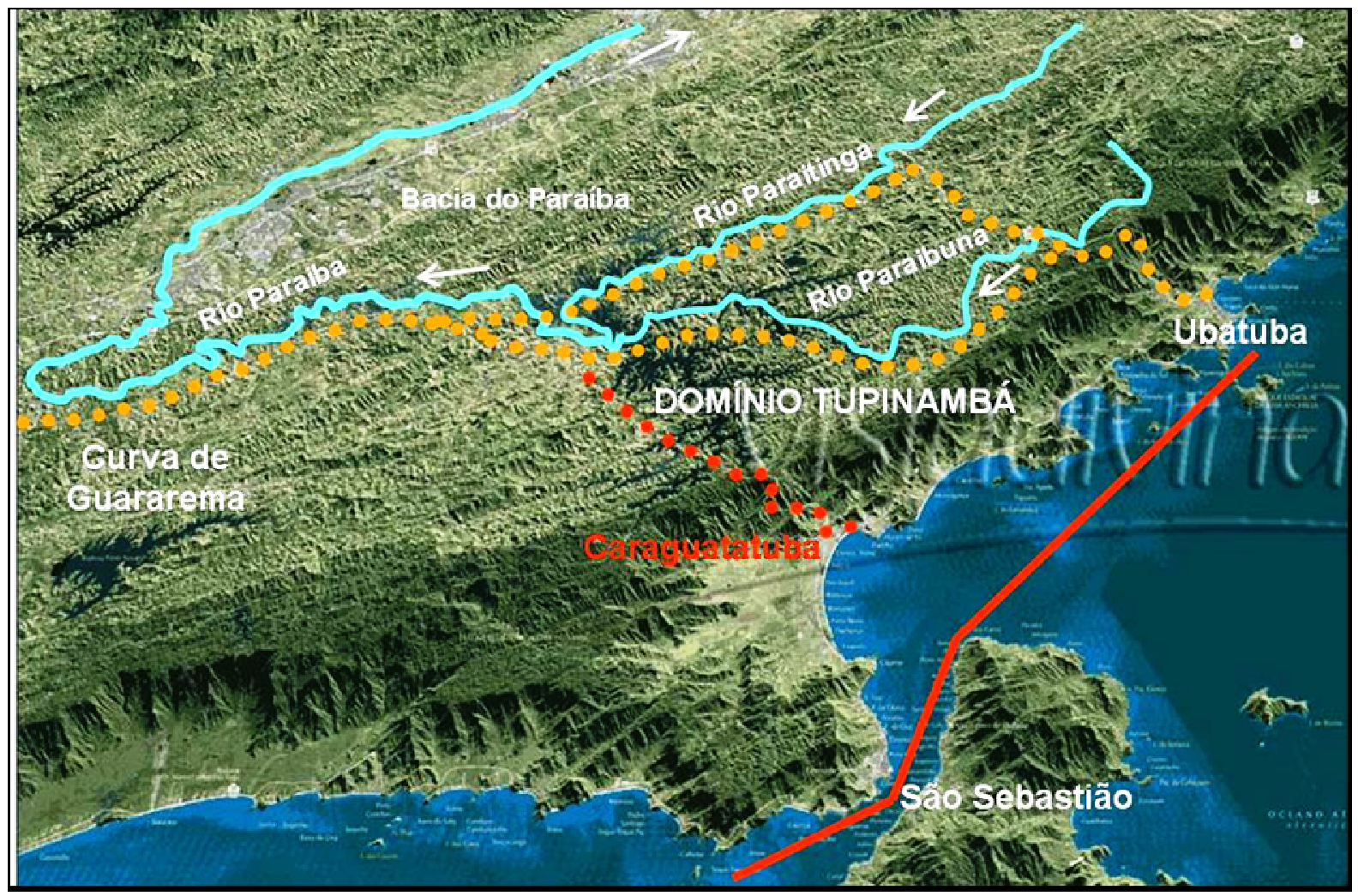

Figura 88. Particularidades. Fonte: www.vistadivina.com. Acrescent. textos e sinalizações do autor. 


\section{8 "Vila Nova da Exaltação da Santa Cruz do Salvador de Ubatuba"}

Estudos divergem sobre a etimologia da palavra Ubatuba. Alguns interpretam o vocábulo de origem Tupi como relativo ao lugar ou porto das canoas (BUENO, 1983, p.562), derivado de ybá-tyba. Na mesma linha, Theodoro Sampaio acrescenta que "O nome Ubatuba... poderá ser decomposto de UBA-TYBA, significando abundância de canoas". Mas esse mesmo autor observa que também poderia ser corrupção de "[...] UYBATYBA, o flechal, o canavial bravo". Desta forma concorda com Azevedo Marques (cana silvestre), Rosendo Sampaio Garcia (sítio de flechas, flecha), e Plínio Airosa (onde há abundância de caniços de flechas). Washington de Oliveira (1977), eminente pesquisador natural de Ubatuba, ao registrar as fontes acima concluiu: "Se nos fosse permitido opinar sobre o assunto não vacilaríamos em afirmar que Ubatuba, na linguagem tupi, sem dúvida alguma quer dizer: flechal, taquaral, muita ubá." (OLIVEIRA, 1977, p. 16). Lembra que várias áreas do município continuam cobertas por canaviais silvestres, "[...] vegetação conhecida entre nós por canas de ubá [...]", e cita um local próximo ao centro da cidade denominado "Sertão do Taquaral". (OLIVEIRA, 1977, p. 16). Não teríamos dúvida em concordar com o autor quanto à toponímia da futura cidade. Ainda, retomando seus argumentos, o sufixo tuba (muito), só poderia ser associado a canoas em "episódios transitórios". Não caracterizariam a particularidade local, de baixa 
densidade demográfica como veremos a seguir. Muito mais significativa é a associação com o artefato bélico, somada à importância estratégica da região. De Ubatuba, por mar ou por terra, os Tamoios partiam para o confronto com os Tupiniquins. Sem dúvida precisavam de muitas flechas.

A primeira menção documentada sobre Ubatuba, que conhecemos, é a descrição sutil que Hans Staden deixou sobre a localidade, por onde passou em meados de agosto de 1554. De tão singelo, o texto revela-se extremamente precioso:

\begin{abstract}
Uma noite acampamos num lugar que também se chama Ubatuba. Aí apanhamos muito peixe, piratís ou tainhas, que são tão grandes como um lúcio bem desenvolvido. Soprava um vento forte. Tagarelavam comigo e tinham muito que perguntar. Disse eu então: 'Este vento sopra sobre muitos mortos'. Como, porém, um outro grupo da sua gente, que também se achava a caminho em canoas, pelo rio Paraíba, tinha entrado na terra, pensavam eles que já tivessem esses talvez atacado a região do inimigo, e deles poderiam alguns ter sido mortos. Como depois tive ciência, assim tinha acontecido (STADEN, 1974, p. 125).
\end{abstract}

Livre do cativeiro escreve sua aventura, editada em 1577. É notável que, com a memória ainda fresca, refere-se ao "lugar" onde "acampamos" e não menciona a existência de aldeias. Se existissem, seria omissão pouco provável não descrevêlas. O cronista mercenário, atento com as possibilidades de fuga, foi minucioso na descrição dos acampamentos, dos grupos locais e de todo o contexto espacial Tupinambá ${ }^{14}$. Nossa ressalva procede pela informação contida na fonte etnohistórica citada adiante, onde se comprova que, cerca de nove anos após o pernoite de Staden, havia duas aldeias na localidade de Ubatuba. Não podemos deixar de

\footnotetext{
${ }^{14}$ O prisioneiro era obrigado a acompanhar seu "senhor", aquele que o prendeu na emboscada e agora decidia seu destino. Por isso acompanhava o guerreiro em suas movimentações, geralmente amarrado com uma corda no pescoço. A estada em Ubatuba pode ter sido cautelosa. Partiram de Angra para o ataque rotineiro a Bertioga, mas devem ter encontrado mau tempo: "Soprava um vento forte." No inverno os ventos de sudoeste, associados às frentes frias, costumam ser implacáveis em toda costa Sudeste. Conforme a intensidade, contrários ao fluxo predominante da corrente marinha, desestabilizam a superfície das águas e causam "ressacas" indesejáveis à navegação. Um desses fenômenos, de proporção surpreendente, pode ter aniquilado a pobre Vila de São Vicente em 1542.
} 
supor que eram ocupações recentes quando os jesuítas Manuel da Nóbrega e José de Anchieta desembarcaram ali em 1563. Refletiam o crescimento demográfico da sociedade indígena ou as tensões provocadas pela presença francesa, desde 1555, na baía da Guanabara, região onde se concentrava a maioria dos grupos locais Tupinambá. Estavam aguçados os conflitos entre essa tribo, aliada dos calvinistas, e os portugueses, associados aos inimigos seculares Tupiniquins. Este cenário Staden não assistiu. Deixou o Brasil em 31 de outubro de 1554. Mas a real ameaça que a Confederação dos Tamoios representava para São Vicente, certamente fomentada pelos aliados da "França Antártica", recrudesceu a ponto dos inacianos arriscaremse em Iperoig, outra denominação da localidade de Ubatuba. A perspicácia do Pe. Nóbrega foi precisa. Estabeleceu um diálogo no arco perimetral da tribo com o objetivo claro de atenuar o foco guerreiro do Rio de Janeiro. Os portugueses não tiveram sucesso no envio de uma esquadra para derrotar os franceses em 1560 . Nóbrega entendeu que o projeto colonial português corria sérios riscos com os Tupinambás confederados. Mas acertou no alvo. Os caciques de Ubatuba (Pindobuçú e Cunhambebe) cederam aos argumentos dos hábeis catequizadores e iniciou-se em Iperoig um processo de negociações. O provincial com alguns guerreiros viajam a São Vicente e Itanhaém na busca de entendimentos, enquanto Anchieta, refém em Ubatuba, amarga as incertezas do seu destino: "[...] cada dia bebíamos muitos tragos de morte [...]." (RIBEIRO, 1993, p. 260). O episódio na região é conhecido como a Paz de Iperoig. Na verdade foi uma trégua ardilosa até as forças portuguesas se recomporem, com forte participação de Nóbrega, para lograr a expulsão dos franceses, processo que motivou a fundação do Rio de 
Janeiro em 1565 e, na esteira das ações dominadoras, aniquilou os Tamoios refugiados em Cabo Frio $^{15}$.

A “Carta ao Geral Diogo Laines, de São Vicente, 8 de janeiro de 1565”, em que Anchieta registra sua estada em Ubatuba, informa-nos sobre a existência de duas aldeias, com precisão do local da principal delas:

[...] estando nós outros [com Nóbrega] no fim da praia, apareceu uma canoa que vinha do Rio de Janeiro, nós outros tomamos por melhor conselho ir à aldeia de Pindobuçú, porque estando ele presente, nos parecia estaríamos mais seguros de qualquer encontro e demos a andar pela praia e às vezes a correr, porque pudéssemos passar antes que a canoa chegasse [...], e este foi um outro trabalho, ao menos dos maiores que o Padre Manuel da Nóbrega teve em sua vida, porque estando ele mui fraco de suas contínuas indisposições e junto com o da má vida que ali se passava, se queria correr não podia, se não corria punha-se em perigo de vida; todavia correu quanto pode, e mais do que pôde, até o fim da praia, onde, antes da aldeia, que está posta em um monte mui alto, corre uma ribeira d'água mui larga e que dá pela cintura, o Padre ia com botas e calças que comumente traz por as chagas que tem em as pernas, do que ficou mui mal tratado, se se punha a descalçar chegava a canoa, que estava já detrás de uma ponte [ponta] mui próxima de nós outros, de maneira que o tomei às costas e o passei; mas em meio do rio vínhamos já todos molhados, e como minhas costelas ainda cansem e doem como soíam, e têm mui poucas forças, não o pude bem passar e foi forçado o Padre a lançar-se na água, e assim passou todo ensopado, de maneira que escassamente tivemos tempos para nos poder meter pelo monte e encobrir-nos com as árvores, pois pelo monte arriba foi cousa de ver, ficou-se o Padre, as botas, calças, e roupeta e todo molhado, com toda a roupa na mão, começamos a caminhar, mas ele nem atrás, nem adiante podia ir, entanto que, vendo o seu trabalho e que era impossível chegar à aldeia, Ihe cometi que nos escondêssemos no bosque até que passassem os da canoa, os quais já estavam no ribeiro gritando, e se não fora a tardança que fizeram em tirar a canoa à terra, bem creio que não chegaríamos à aldeia, à qual ainda chegamos, porque encontramos com um índio dela, do qual, com muitos rogos e prometer que se lhe pagaria, alcancei que, agora às costas, agora puxando pelo bordão, levasse o Padre, e assim, quase sem

\footnotetext{
${ }^{15}$ Anos depois o Governador Antônio Salema resolveu combatê-los no refúgio "[...] onde acharam os tamoios com cercas muito fortes, recolhidos nelas com alguns franceses dentro, onde uns e outros se defenderam valorosamente às espingardas e flechadas; e, não podendo os franceses sofrer o aperto em que estavam, se lançaram com o governador, que lhes desse a vida, com que os tamoios foram entrados, mortos infinitos, e cativos oito ou dez mil almas. E com essa vitória, que os portugueses alcançaram, ficaram os tamoios tão atemorizados, que despejaram a ribeira do mar, e se foram para o sertão [...]." (SOUSA, 1987, p. 107). Esse ataque ocorreu no dia 26 de setembro de 1575 quando o cacique Jupuguaçu, cedendo a uma negociação traiçoeira de Salema, abriu as portas da fortaleza "plantando uma cruz para que os portugueses, entrando, não fizessem mal a ninguém"... (REIS, 1979, p. 56).
} 
respiração, chegou às casas [...]. (RIBEIRO, 1993, p. 259, grifo nosso).

No escopo do documento não há referência sobre a localização do sítio da outra aldeia. Mas deixa transparecer em outras passagens da carta que não ficavam distantes, ocupando as adjacências do mesmo recorte costeiro. Logo que desembarcam na enseada de Ubatuba (localidade à qual se refere como "primeiros lugares dos inimigos" ou mais significativamente como "aquela fronteira"), comenta que "Chegados à praia [...] Visitamos ambas as aldeias" (RIBEIRO, 1993, p. 257).

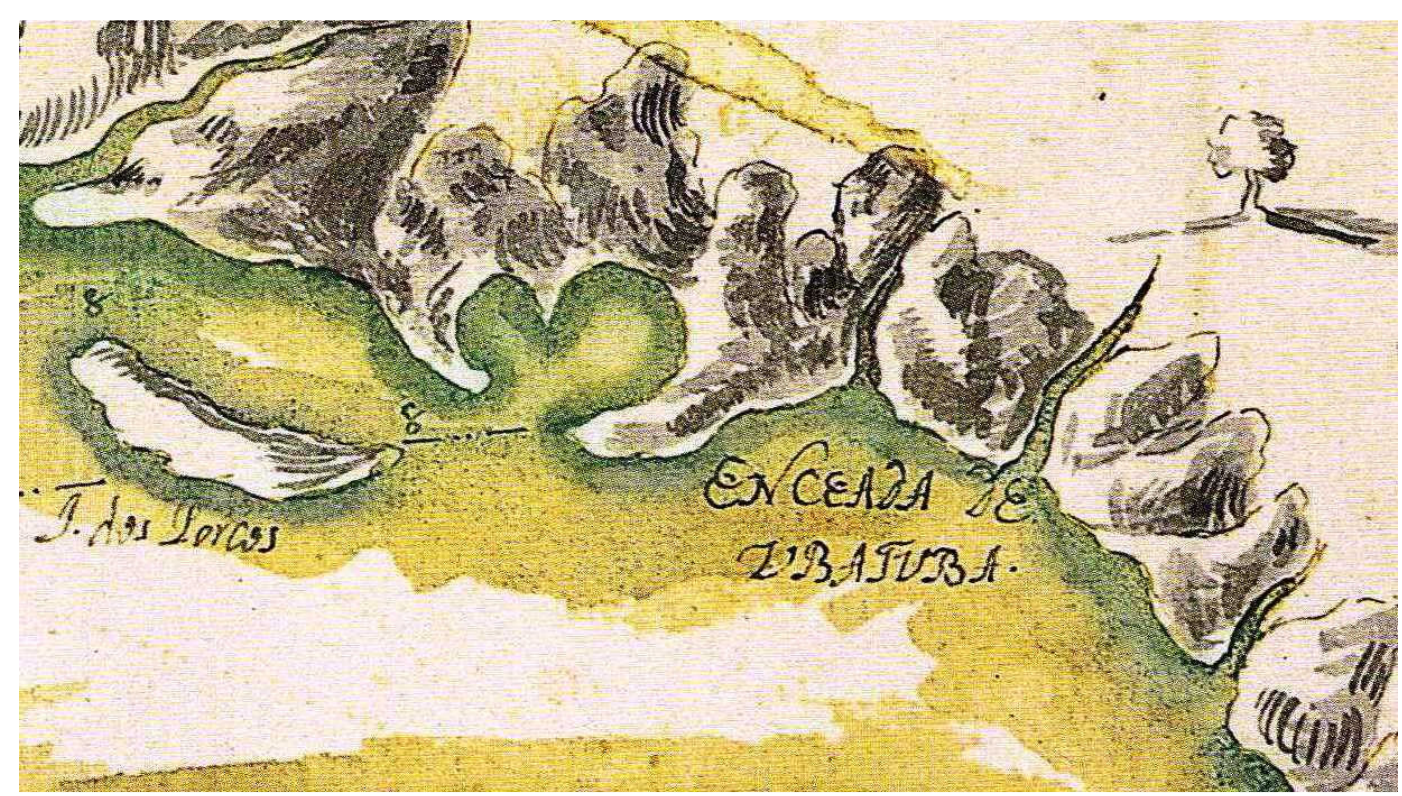

Figura 89. "Aquela fronteira". "Primeiros lugares dos inimigos". Detalhe da Carta 6 da "Descripção de Todo o Maritimo [...]" mencionada. João Teixeira Albernaz I, 1640. Fonte: MARTINS, 2003.

Pindobuçú era o "grande principal" da aldeia anteriormente descrita. A outra tinha por líder Cunhambebe. Há referências imprecisas de tradição oral que situam sua aldeia na atual ilha Anchieta, poucas milhas ao sul de Iperoig; é possível que tenha se transferido para lá posteriormente, na dinâmica dos seus costumes. Nessa ocasião, porém, parece intrínseco que as duas ocupavam a mesma vizinhança. Além de estarem na mesma praia, o jesuíta deixa transparecer relativa proximidade ao referir-se a Cunhambebe: 
[...] nós fomos mui de manhã à sua aldeia, onde ele havia dias que nos havia mandado fazer uma casita pequena, em meio dela, para dizer missa, e quando nos viu, assim ele como todas as mulheres da aldeia receberam tanta alegria [...], e foi-se logo à outra aldeia a convidar aos outros. (RIBEIRO, 1993, p. 260).

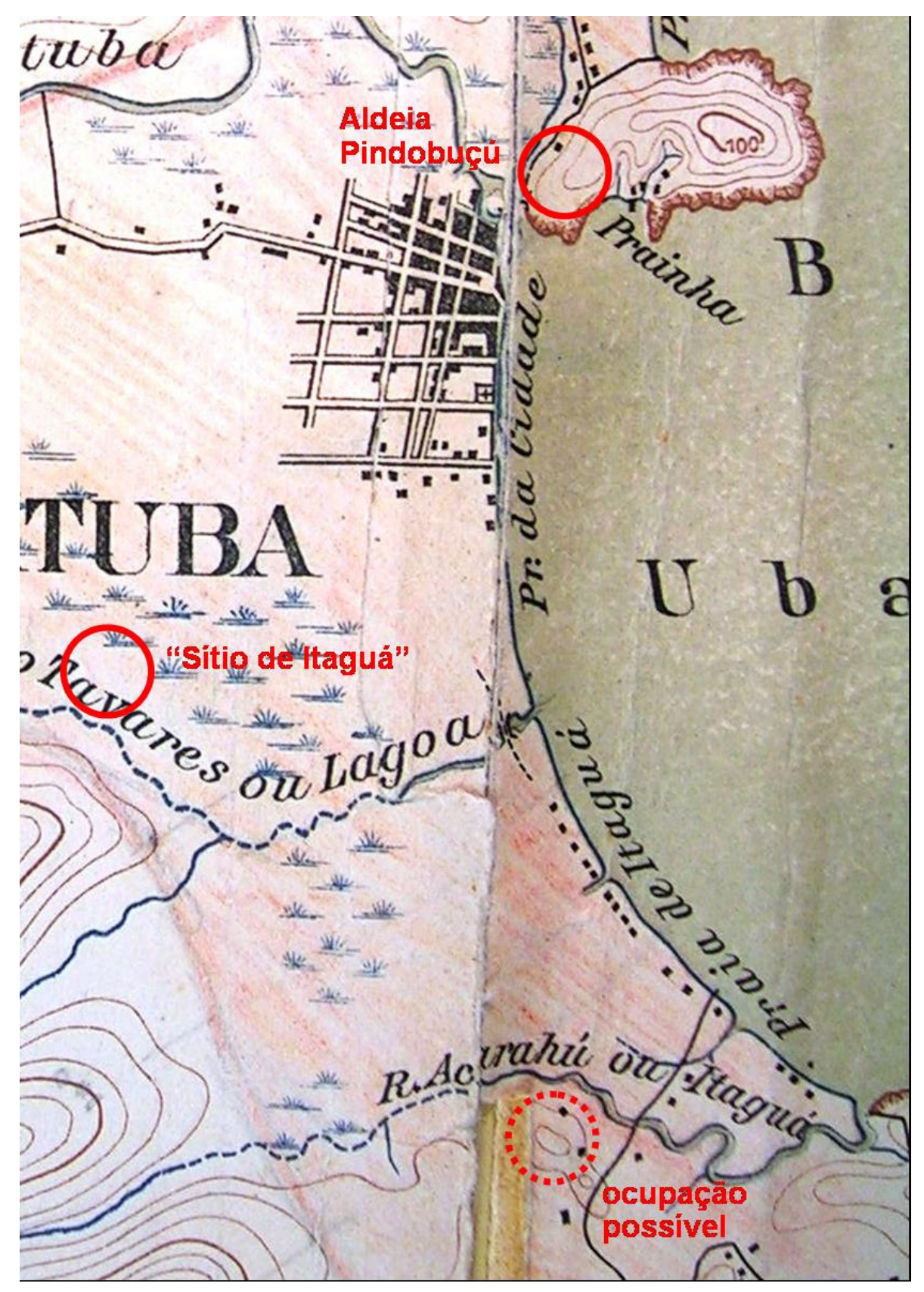

Figura 90. Aldeias 1. Detalhe da Planta entre a Enseada de Caraguatatuba e a Praia de Itamambuca. Do livro Exploração do Litoral 1ạ Seç̧ão. CGGESP, 1915. Fonte: Bibl. FAUUSP, LR 918.161 Sa63. Acresc. textos e sinalizações do autor.

Além do enquadramento das duas aldeias sugerido na mesma enseada, há uma importante pesquisa arqueológica que contribui para a suposta localização do 
sítio da segunda aldeia, em harmonia com os indícios deixados por Anchieta. Tratase da identificação do local denominado "O Sítio do Itaguá". Localiza-se no mesmo entorno praiano, palco da permanência dos jesuítas em 1563,

[...] sobre uma pequena elevação cristalina isolada na planície costeira [...]. Próximo à elevação há um pequeno curso d'água conhecido como rio da Lagoa, que durante a preamar sofre influência da água salgada, ocorrendo em suas margens vegetação típica de mangue. A área, considerando-se as ocorrências de superfície é de mais ou menos 580,00 m² [...]. (SCATAMACCHIA; UCHÔA, 1993, p. 163).

No estudo denominado 0 contato euro-indígena visto através de sítios arqueológicos do Estado de São Paulo, as pesquisadoras Maria Cristina Scatamacchia e Dorath Pinto Uchoa (1993), identificam no Sítio do Itaguá evidências da ocupação Tupi (restos de fogueira, grande quantidade de carvão, buracos de estacas, restos de um sepultamento e material cerâmico) e artefatos de procedência européia (4 contas de vidro, 1 pequeno disco de cobre).

Entre o material cerâmico existe uma peça de grande interesse para o estudo de contato cultural, pois nela estão cristalizados os elementos resultantes da influência deste encontro. Corresponde a um exemplo típico do processo de aculturação, pois a forma corresponde à cópia de um prato europeu, com técnica indígena, mas representando um padrão de pintura existente em louça portuguesa do séc. XVI e que foge aos padrões típicos de decoração deste grupo. A presença desta peça de cerâmica com forma aculturada exclui a possibilidade do material europeu ter sido depositado em época posterior a ocupação do sítio, uma vez que não possuímos uma datação absoluta. (SCATAMACCHIA; UCHÔA, 1993, p.164).

Entre a narrativa etno-histórica e a pesquisa arqueológica, parece razoável a hipótese do "Sítio de Itaguá" corresponder à segunda aldeia encontrada por Anchieta pela coerência com seus relatos. No contexto dos grupos locais Tupinambá, instalados em acrópoles, tangenciados pelos corpos d'água principais da região e com visão de $360^{\circ}$ do entorno, principalmente do mar, há ainda outro local que poderia ser aceitável como sua localização, na mesma enseada. São dois 
outeiros, relativamente mais afastados, com as mesmas qualificações ambientais. Atualmente estão edificados e não há nenhum registro documental que comprove sua ocupação pregressa por aldeias indígenas (Figura 90, p. 167).

De acordo com as escalas dessas instalações, a citação de Neme e Beltrão da página 64 contribui para pensarmos que são posteriores à passagem de Staden pela localidade.

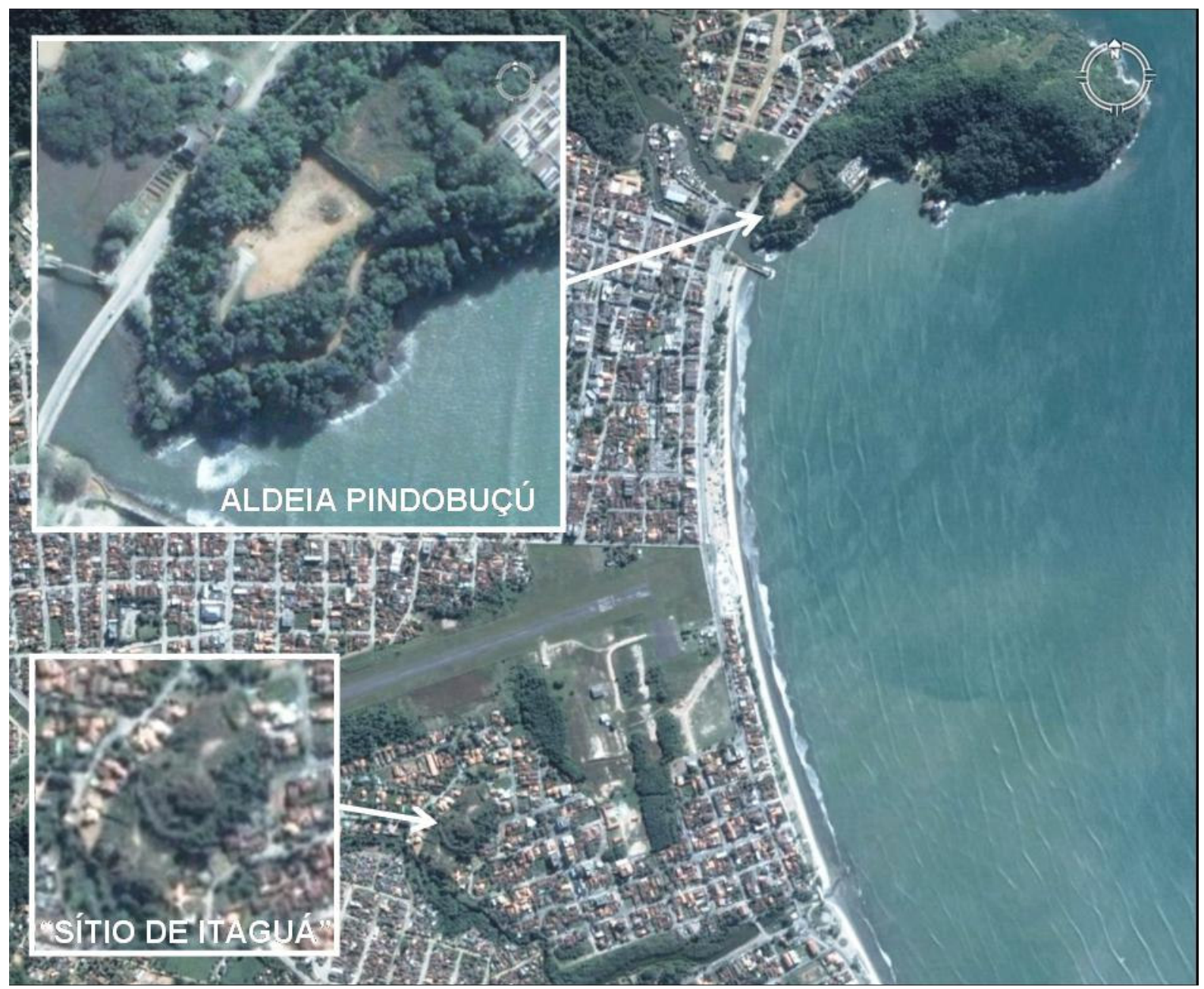

Figura 91. Aldeias 2. Área central da cidade com os sítios em acrópole. Fonte: www.earth.google.com. Acrescentados textos e sinalizações do autor.

A identificação da aldeia do cacique Pindobuçu e as descobertas arqueológicas do Sítio de Itaguá reiteram os critérios de ocupação Tupi litorâneos. Estão presentes o agenciamento à rede fluvial, a proximidade das matas e terras 
férteis para os cultivos e lenha, a abundância de peixes e a condição portuária de enseada abrigada, adequada aos seus meios, com a particularidade de que "A localização alta na maioria dos sítios, propiciando uma boa visão dos arredores e defesa mais fácil, parece indicar um clima bastante belicoso." (PROUS, 1992, p. 387). A este contexto ecológico acrescenta-se a inserção da localidade na paisagem regional.

O panorama geográfico decerto contribuiu para as escolhas de ocupação; é um dos vetores da composição ambiental das intrínsecas vivências indígenas. Da baixada santista para o Norte, na verdade direção Nordeste, até a baía da Guanabara, a Serra do Mar mantém um perfil homogêneo em relação à linha litorânea. Seus contrafortes abruptos de escarpas festonadas, com altitudes de até mil metros, muitas vezes debruçam nas águas da marinha, limitando as planícies costeiras a trechos de pouca expressão. Este relevo de recortes proporciona pequenas enseadas abrigadas de ventos e correntes marítimas, com praias de pequena amplitude em cenários de extrema beleza. Assim ocorre na área central do atual município de Ubatuba e em outras localidades da vizinhança (Maranduba, Rio Escuro, Itamambuca, Ubatumirim, etc). Estas planícies, por sua relativa extensão com maior capacidade de drenagem, oferecem os rios mais expressivos desta costa. O Rio Grande de Ubatuba, com estuário na sede da cidade e no sopé da antiga Aldeia Pindobuçú, por si só seria um atrativo especial para ocupação desse recorte costeiro. Um segundo fator soma-se a este referencial: as vertentes de suas cabeceiras, por sua escala, recortam significativamente o contraforte serrano nessa latitude. Esta particularidade do relevo favorece o acesso ao planalto pela maior amplitude linear do plano inclinado da costa. Estes "recortes em cunha" no relevo serrano, não por acaso, foram apropriados ao "peabirus", aos caminhos, às estradas 
de ferro e rodagem e, atualmente às nossas rodovias. São os cenários geográficos que disponibilizaram as articulações entre o planalto e o nosso litoral. Ubatuba é típico, mas é o que também ocorre na Baixada Santista, em Caraguatatuba, em Parati e em Angra dos Reis (Figura 14, p. 65). Um terceiro fator, ainda, complementa a escolha de Ubatuba: no acesso facilitado ao planalto por esta diretriz estão os rios Paraibuna, Paraitinga e, no fundo do vale, o Paraíba: esta rica rede fluvial, paisagem típica dos povos Tupi-Guarani, além de apontar para os domínios Tupiniquins, complementava os "nichos" ecológicos litorâneos pela diversidade de recursos naturais.

Ubatuba vive um divisor de águas com a "Paz de Iperoig". A partir daquela data, o destino da nação Tupinambá está traçado. Os grupos locais seguramente amargaram as conseqüências disso. Convertidos, supõe-se que, se não foram mortos na guerra subseqüente, perderam sua identidade cultural, e conseqüentemente suas representações espaciais. Não sabemos o destino exato de Pindobuçú, Cunhambebe e de seus descendentes. Se levados a aldeamentos jesuíticos, se escravizados, ou se persistiram nos seus lugares de vivência estreitando o encontro cultural, tornando-se, quem sabe, raízes dos povos caiçaras que ainda habitam a região. Antes dos desfechos finais no Rio de Janeiro, no ano seguinte das negociações, ainda temos alguma notícia de Ubatuba. A caminho da Guanabara, partindo de São Vicente em 19 de março de 1564, a dupla de inacianos resolve aportar na antiga "fronteira" onde Anchieta conta que:

[...] fomos a visitar nossos antigos hóspedes de Iperuig, como lhes havia prometido que havia de tornar quando me vim, os quais nos vieram a ver ao navio e me trouxeram os $\operatorname{livros}^{16}$ e tudo o mais que Ihes havia deixado em guarda e algum refresco. Partimos, donde chegamos ao Rio à sexta-feira santa [...]. (RIBEIRO, 1993, p. 261).

\footnotetext{
${ }^{16}$ Conta a tradição que Anchieta escreveu o poema De Beata Virgine Dei Matre Maria nas areias de Ubatuba. Pelo volume da obra deve ter garantido a memória com anotações...
} 
Após este importante evento do primeiro século colonial, a história deixará Ubatuba dormente por mais de setenta anos.

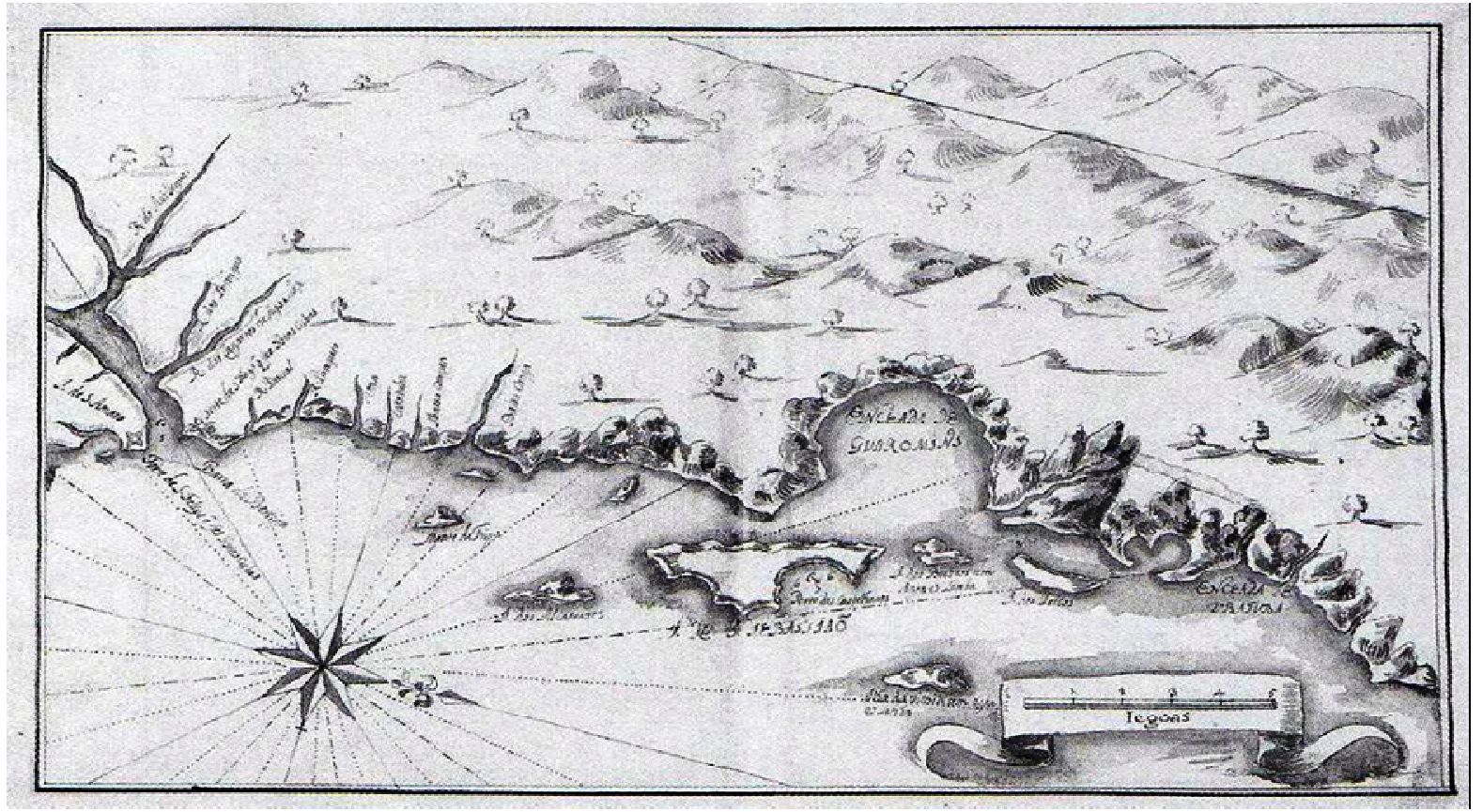

Figura 92. Descrição. Carta 6. Fonte: (MARTINS, 2003).

A figura acima é uma das 32 cartas parciais da DESCRIPCÃO DE TODO O MARITIMO DA TERRA DE S CRVZ CHAMADO VVLGARMENTE O BRAZIL. Feito pos João Teixeira Cosmographo de Sua Magestade. Anno de 1640. João Teixeira Albernaz I, no descritivo desse recorte da marinha relata:

Da Barra de Bertioga vay a costa voltando para o Norte ate a Enceada de Ubatuba em distancia de 25 legoas terra toda montuoza ao longo do Mar sem povoacãos nossas, nem Porto notavel, só na Ilha de S. Sebastião tem hum porto da banda do Norte a que chamão dos Castelhanos com 5, e 6 braças de fundo. Está esta Ilha lançada ao rumo do Nornoroeste perto da Costa da Enceada dos Guaromins, tem 5 legoas em comprido e huã legoa apartada - dos Buzios que tem Agoa e Lenha: e outra ao Norte de S. Sebastião em distancia de tres legoas a que chamão da Victoria que tambem tem Agoa, e Lenha.

Observa as ilhas, mas não menciona nem ilustra as Vilas de São Sebastião e Ubatuba, fundadas em 1636 e 1637 respectivamente. Provavelmente o levantamento é anterior à elevação das vilas, justificando não estarem nos desenhos iluminados e descritos em 1640. O relato deixa a impressão que não navegou no canal entre a ilha de São Sebastião e o continente ao descrever que era uma "[...] 
terra [...] sem povoações nossas, nem Porto notável [...]", mencionando apenas o abrigo de Castelhanos, na porção norte da ilha. As condições portuárias do canal sempre foram mais favoráveis, inclusive pelo agenciamento continental. De qualquer forma, a imagem representa o período em que o projeto colonial alcança a região. $\mathrm{O}$ referencial da Enceada de Ubatuba já aparece consolidado na linha da costa.

Quando Jordão Homem da Costa veio fundar a Vila Nova da Exaltação da Santa Cruz do Salvador de Ubatuba, por Provisão de 28 de outubro de 1637 de Salvador Correa de Sá e Benevides, Governador do Rio de Janeiro, a localidade era "um ermo..." (OLIVEIRA, 1977, p. 44). Por isso mesmo teve liberdade de escolher um sítio para sua fundação que viesse ao encontro de sua intenção colonizadora. Não teve dúvida em agenciá-lo na mesma localidade de escolha Tupi. Estava ali o mesmo rio, a mesma planície costeira, o mesmo abrigo portuário, a mesma enseada acolhedora e a mesma diretriz de acesso ao planalto. Só não ocupou o mesmo altiplano da aldeia, não havia razão para isso: eram novos programas sociais. A zona plana da praia era convidativa às instalações das novas tipologias de arquitetura urbana. "Não há dúvida de que a adesão, quase total, aos critérios de escolha de sítios planos, para instalação dos núcleos urbanos, pode ter sido um estímulo significativo para o uso de traçados mais regulares." (REIS FILHO, sd, p. 558). Sua fundação, significativamente contemporânea a São Sebastião (1636), foi uma decisão que teve a chancela da coroa, naqueles tempos unificada. $O$ fidalgo Jordão Homem da Costa recebeu as terras da futura sede por doação de D. Maria Alves, que as obteve de D. Mariana de Sousa Guerra, a Condessa de Vimieiro, donatária da Capitania de São Vicente, neta de Martim Afonso. "Ainda em 1645, Jordão Homem da Costa ostentava o título de Capitão-mor e Ouvidor [...]." (CAMPOS, 2000, p. 67). 


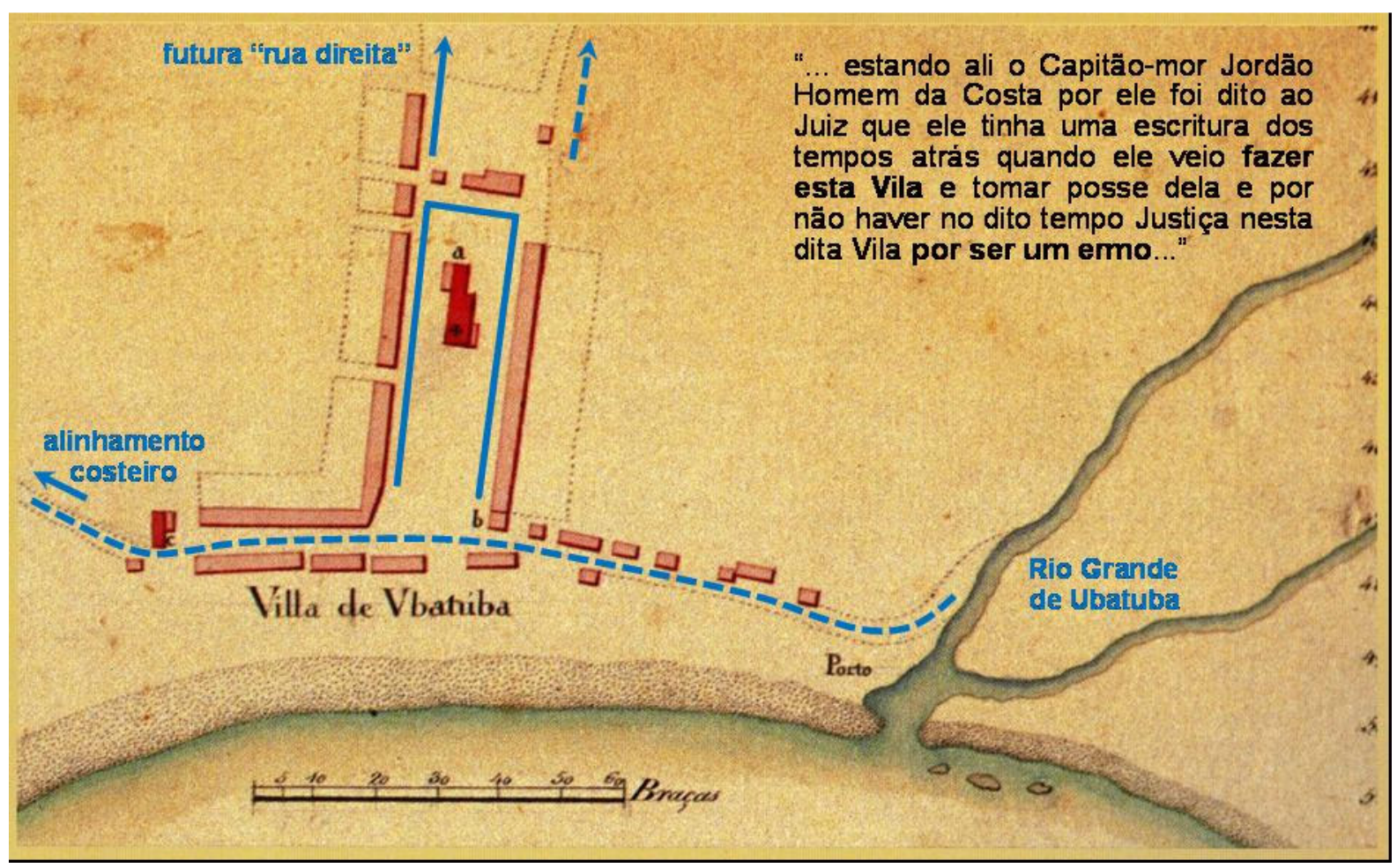

Figura 93. Vila praiana. Detalhe de uma das "Cartas Corographicas e Hydrographicas...", de João da Costa Ferreira, 1815. Fonte: REIS FILHO, 2001, p. 202. Acrescentados textos e sinalizações do autor.

Por volta de 1791, data do levantamento do providencial mapa urbano elaborado por João da Costa Ferreira e Antonio Rodrigues Montesinhos, de todos os núcleos urbanos do litoral da Capitania de São Paulo, Ubatuba era, talvez, o mais modesto. Sua extensão corresponde ao entorno da Matriz. Deixa transparecer um mínimo da racionalidade que remonta à gênese fundadora, expresso pela própria imagem. Vemos, todavia, um alinhamento de traçado sinuoso junto à praia que se estende pela zona plana em direção ao rio da Lagoa (Figura 94, p. 175). Sugere um caminho pregresso ao evento urbano, provavelmente articulador de ocupações 


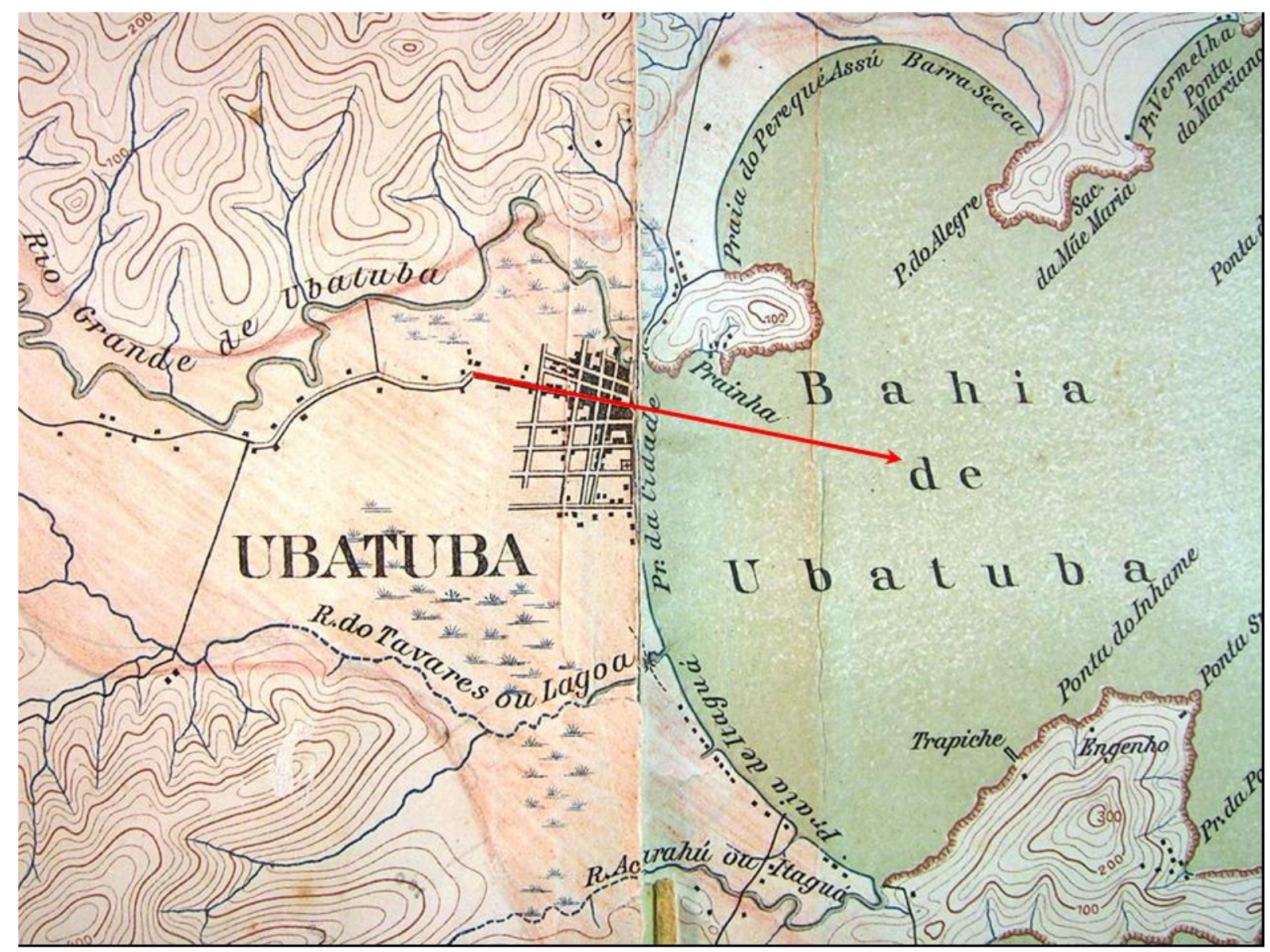

Figura 94. Arredores. Detalhe da Planta entre a Enseada de Caraguatatuba e a Praia de Itamambuca mencionada. CGGESP, 1915. Fonte: Biblioteca FAUUSP, LR 918.161 Sa63. Acrescentados textos e sinalizações do autor.

dispersas na região, de produção rural ou mesmo das remotas instalações indígenas. Reflete o atrativo do porto, com pequenas edificações isoladas, sem a contigüidade marcante do módulo central. Parecem vinculadas à pesca, ou a instalações anteriores ao relativo formalismo do núcleo colonial. A pequena igreja extinta (c), de invocação à N. Sa. da Conceição, localizada na borda desse caminho, talvez confirme a tradição oral de que é anterior à Matriz, essa sim atrelada à fundação da Vila. Pode ter raiz na cristianização que sucedeu à pacificação dos Tamoios. Outro vetor de articulação insinua-se no traçado posterior da Matriz. Tratase da diretriz secular que, perpendicular à praia, do sítio estende-se aos contrafortes da serra, alcançando o planalto. A imagem da Figura 93 insinua o alinhamento contínuo no lado direito do desenho. No lado esquerdo sugere apenas um recorte de 
quadra sem indicação de rua ou caminho. Será nesse setor, no entanto, a sedimentação da "rua direita" de Ubatuba, conforme figura abaixo.

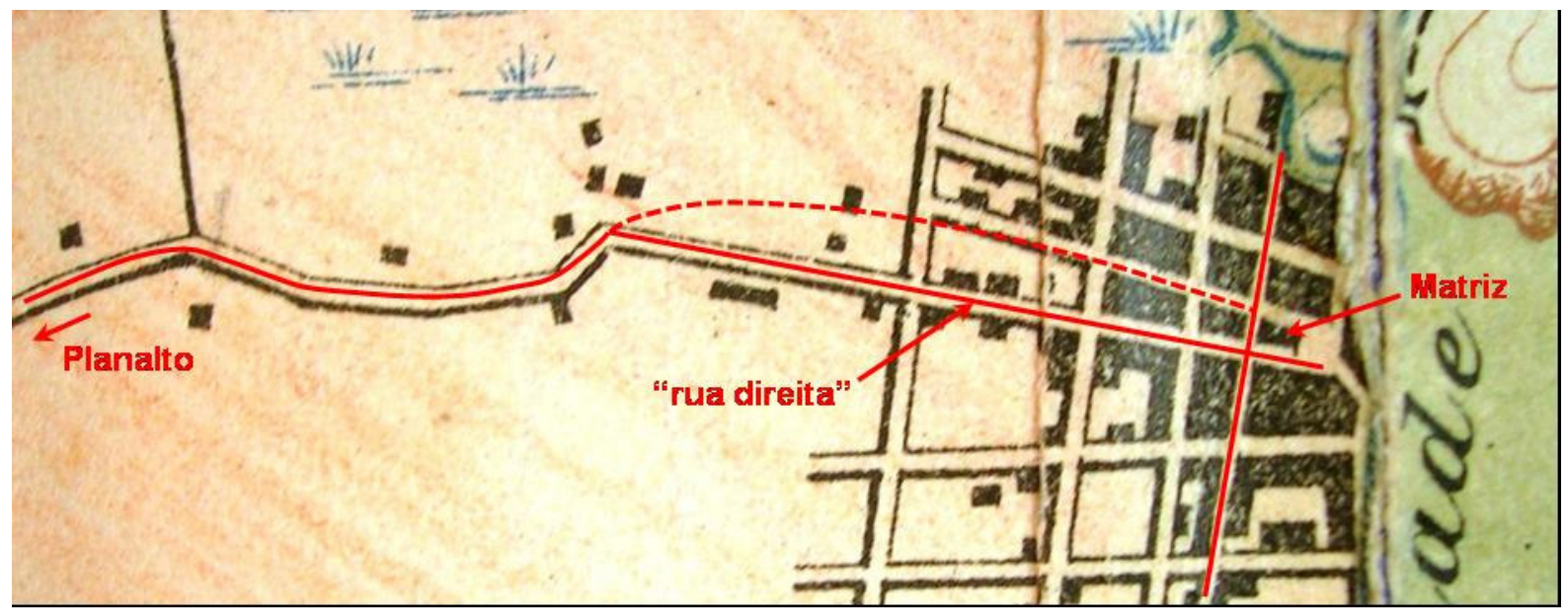

Figura 95. Adequações. Detalhe da Planta entre a Enseada de Caraguatatuba e a Praia de Itamambuca mencionada. CGGESP, 1915. Fonte: Biblioteca FAUUSP, LR 918.161 Sa63. Acrescentados textos e sinalizações do autor.

Pode ser uma adequação da diretriz continental primitiva no intra-urbano (similar a Cananéia), resposta de sua expansão no século XIX quando o café mudou a paisagem do Vale do Paraíba. $\mathrm{O}$ fato é que a direção das vertentes do Rio Grande de Ubatuba para o alcance do planalto corresponde a uma das principais justificativas de escolha desse sítio para ocupação, em todos os tempos. Observamos na Figura 94 que o alinhamento da Matriz enquadrase na paisagem da marinha, com a praça voltada para o portal de acesso das navegações.

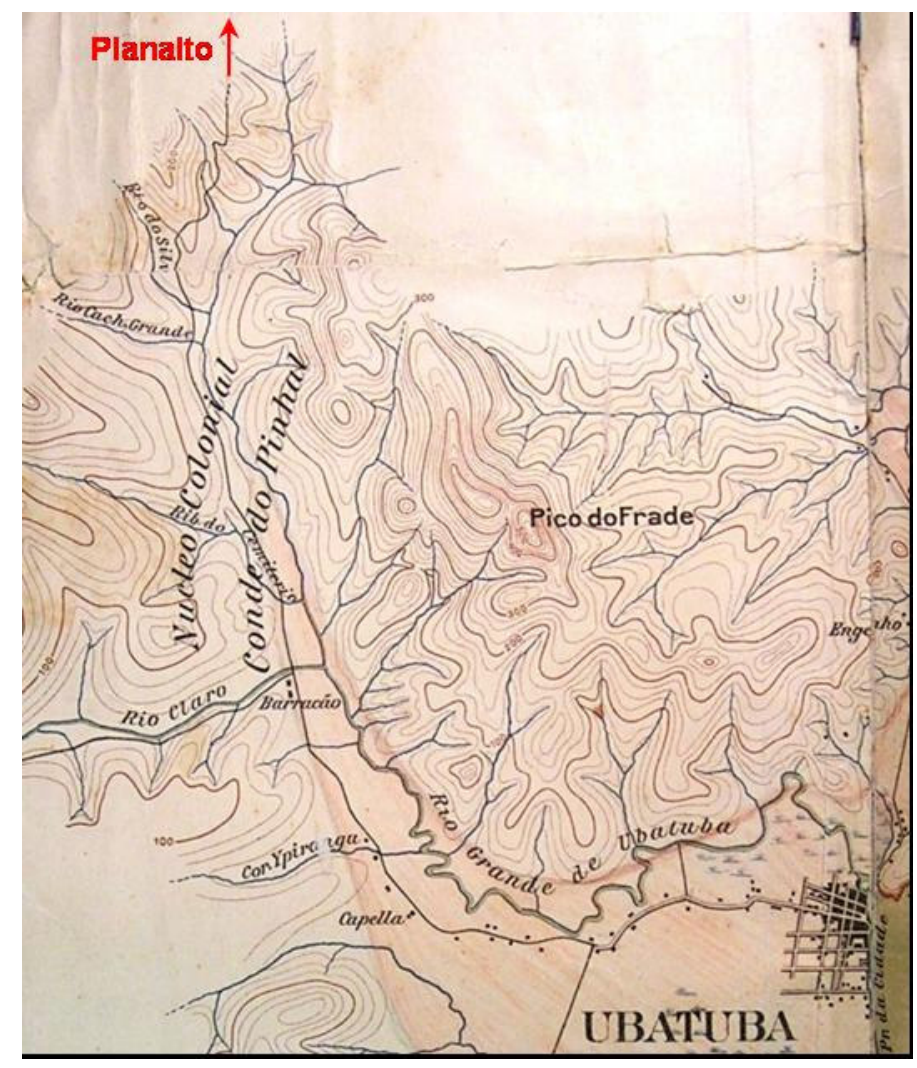

Figura 96. Vereda. Det. da Planta... mencionada. 


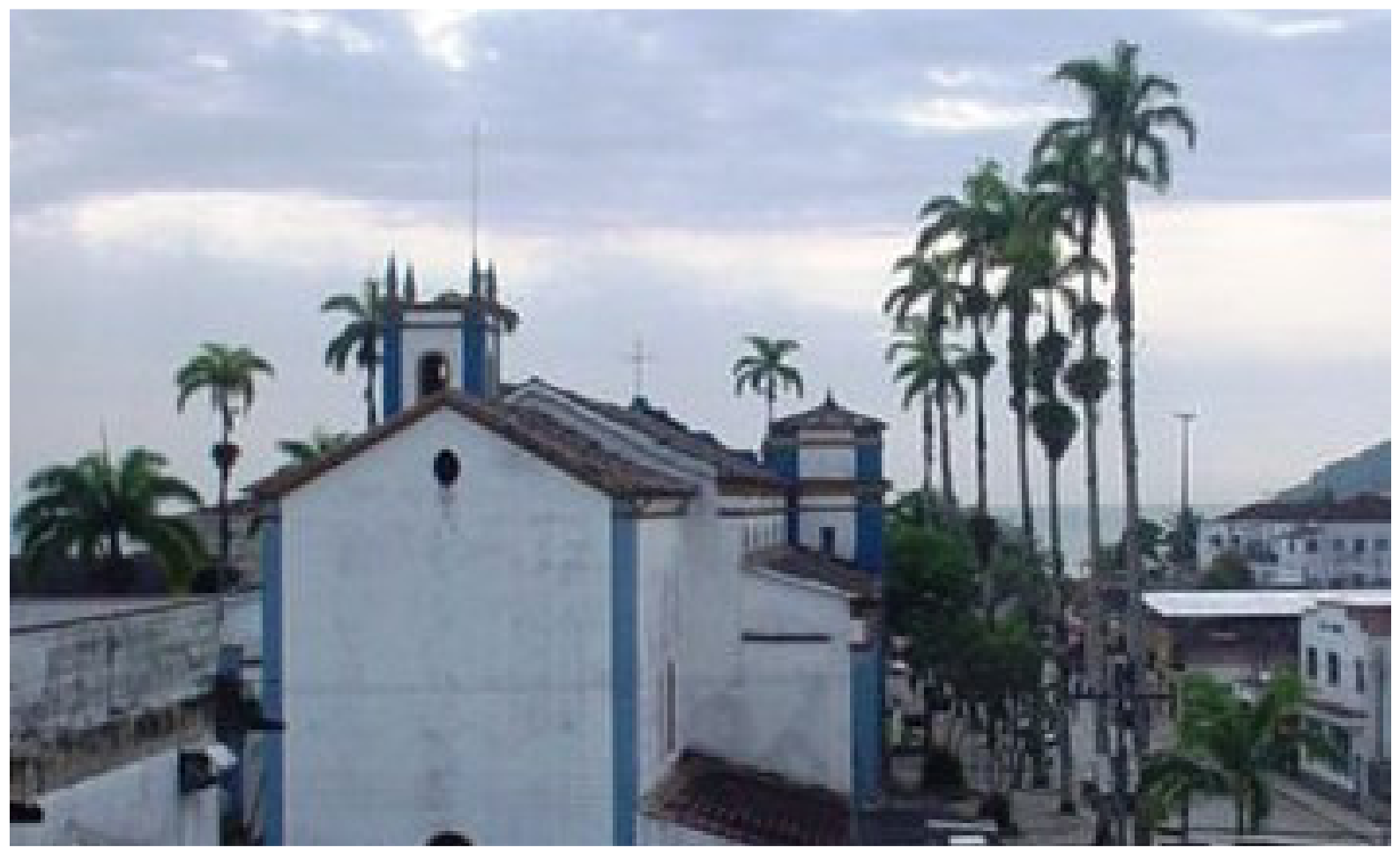

Figura 97. Portal do Mar. Ao fundo, o horizonte marinho. Foto do autor, 2003.

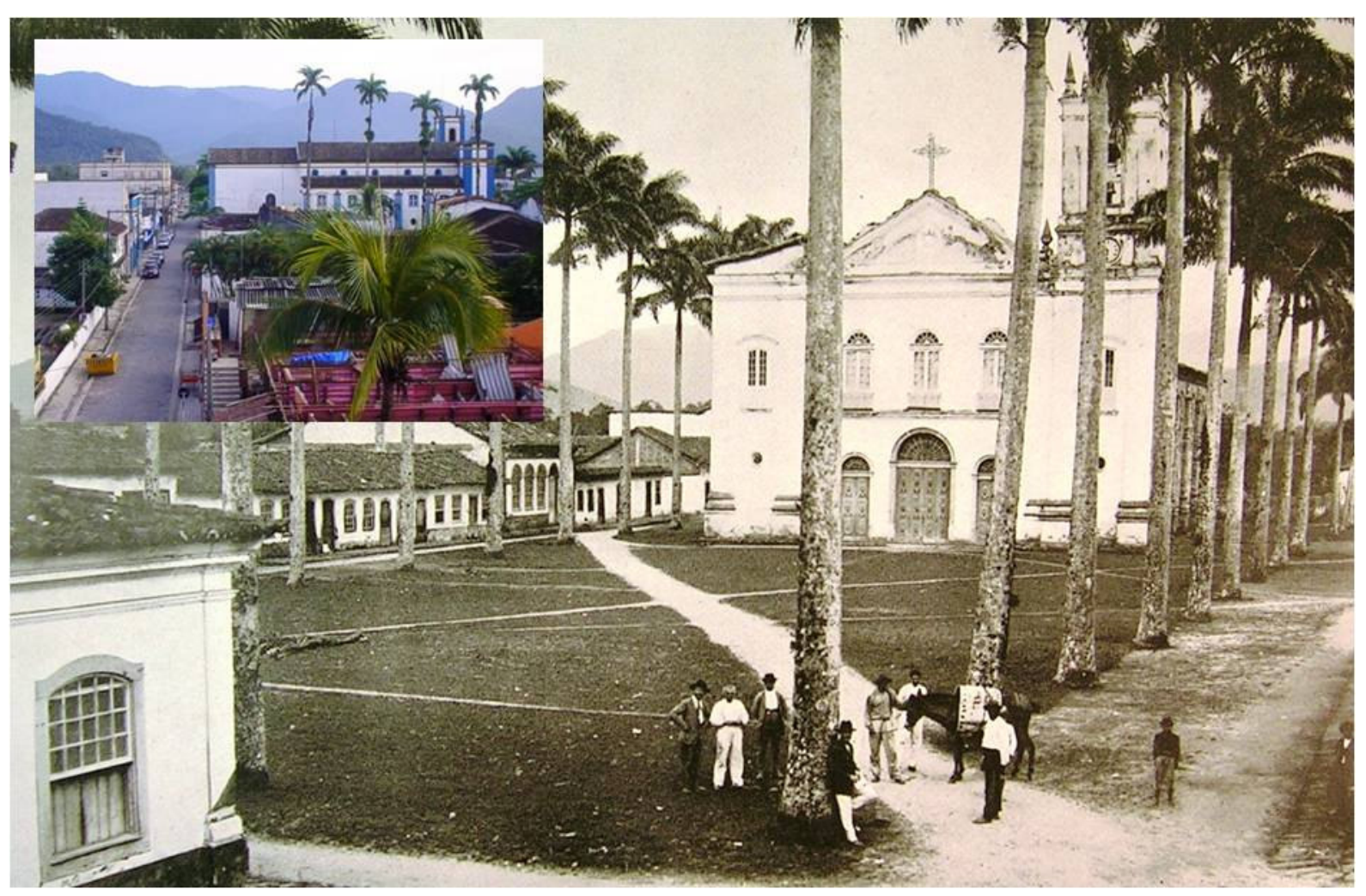

Figura 98. Geometrias. Foto do livro Exploração do Litoral 1ª Secção. CGGESP, 1915. Fonte: Biblioteca. FAUUSP, LR 918.161 Sa63. Foto do autor em detalhe, 2003. 

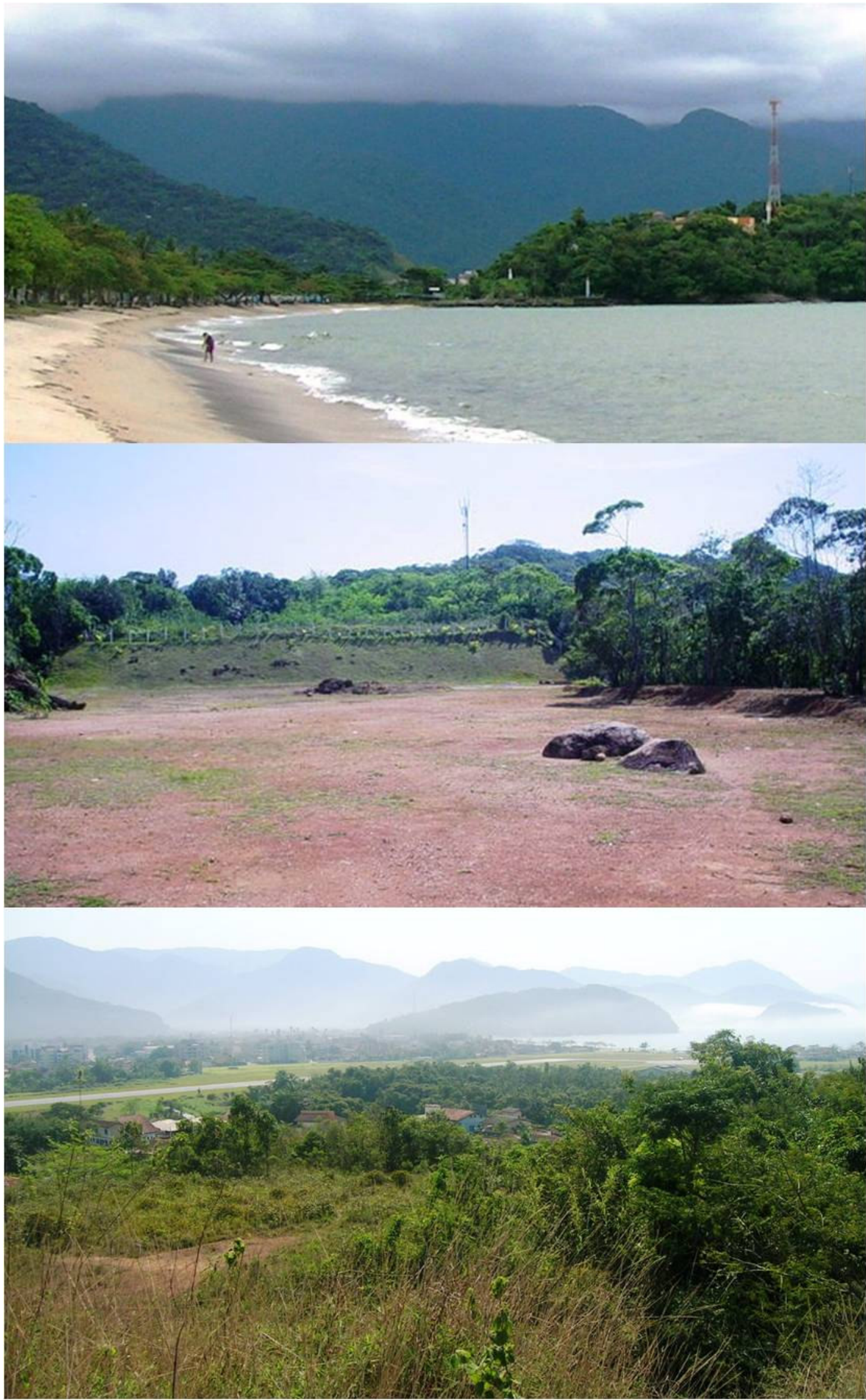

Figura 99. Os sítios. Promontório da Aldeia Pindobuçú no fim da praia. No centro, platô recente dessa ocupação. Na parte inferior, vista do "Sítio de Itaguá" para o centro da cidade. Fotos do autor, 2006. 

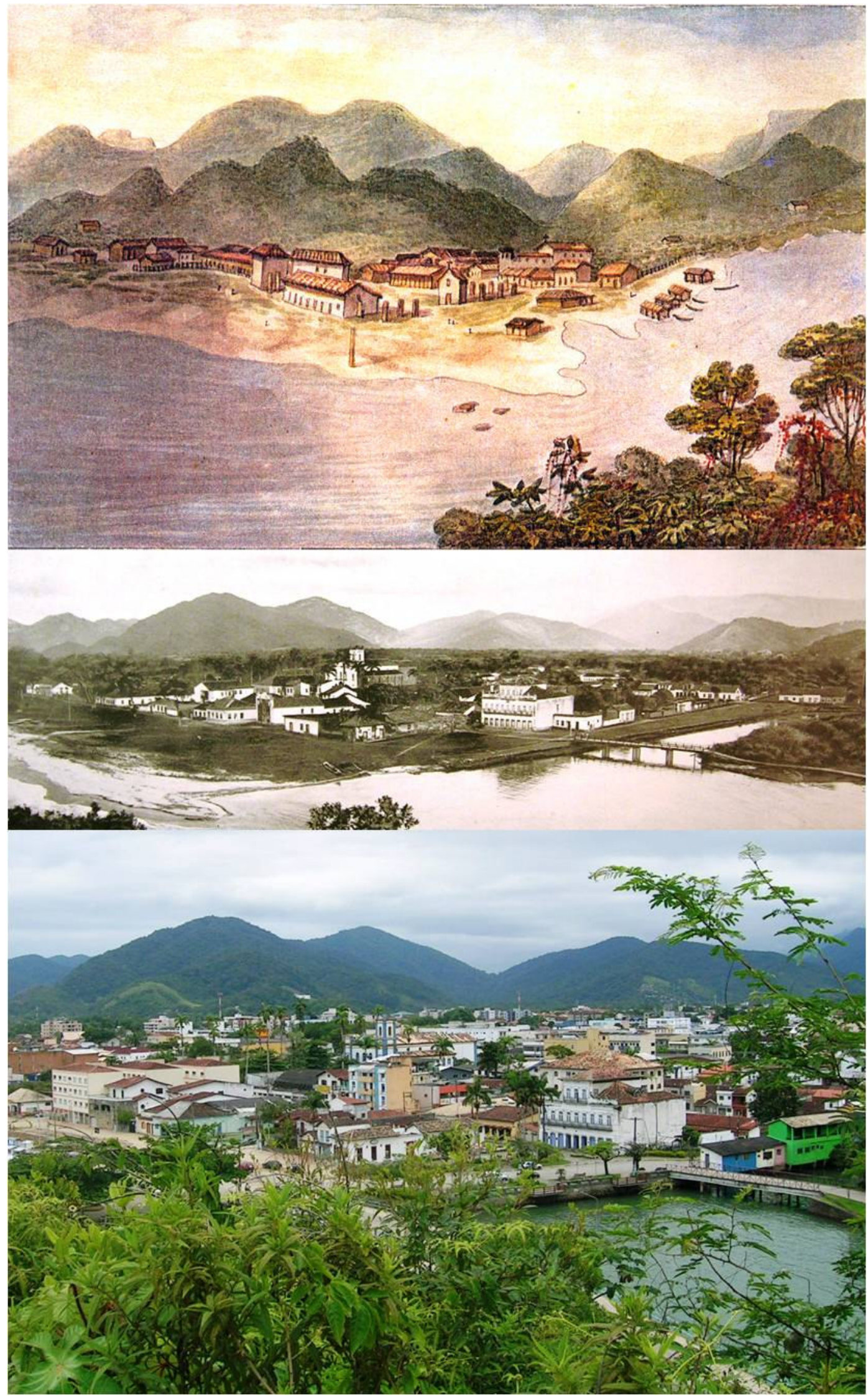

Figura 100. Registros. Na parte superior, pintura de J.B.Debret, 1827. Ao centro, fotografia da CGGESP, publicada em 1915. Foto do autor na parte inferior, 2006. 


\section{CONCLUSÃO}

A disposição dos povoados, vilas e cidades ao longo do litoral brasileiro sempre foi representação, para a historiografia, da interdependência da Colônia face à expansão mercantilista européia. Em conseqüência, os estudos sobre a urbanização, fundamentados nos aspectos estruturais e econômicos da Idade Moderna, têm estes espaços como produto cultural dos grupos dominadores. Generalizam a nossa produção urbana enquanto desdobramento da matriz centralizadora européia, no máximo aceitando que os modelos medievorenascentistas adequaram-se indubitavelmente nos trópicos. Se observarmos as paisagens urbanas de nossas Vilas litorâneas através de cartografias, fotos e desenhos antigos, ou da contemplação de lugares onde conjuntos arquitetônicos preservados nos reportam aos antigos aglomerados, a associação com os modelos históricos adventícios é indissociável. Até porque a arquitetura de raízes européias impõe-se também como símbolo dos novos domínios. A modelagem do espaço físico prevalece com a reprodução de suas técnicas construtivas e adoção de materiais de construção sedimentares. A pedra e cal (somadas a componentes próprios das localidades, como as conchas moídas dos sambaquis de Cananéia e Iguape), as telhas de barro, as portas e as janelas serão suficientes para consolidar a paisagem dos núcleos ${ }^{17}$. Destaca-se no cenário a proeminência do edifício religioso irradiando suas perspectivas. São essas imagens de aglomerados existentes que a historiografia adota, a priori, no alinhamento dos seus estudos. Mesmo focando o enquadramento embrionário das igrejas ou das fortificações (e

\footnotetext{
${ }^{17}$ A arquitetura com essas feições foi mais tardia. Quase sempre foi antecedida nas povoações por materiais mais efêmeros como a taipa-de-mão e o sapê. Sinalizavam uma nítida transição entre a produção dos espaços dinâmicos indígenas e as representações da sociedade que se formava.
} 
seus embasamentos fundiários ou estratégicos, respectivamente), as interpretações recorrentes são de que a produção desses espaços é exclusivamente européia. Observamos a mesma postura metodológica nos trabalhos de autores portugueses dedicados ao "urbanismo colonial português"18. Um olhar sobre a imensidão dos domínios lusitanos permite-nos observar a recorrência do colonizador na apropriação de localidades estratégicas aos seus interesses. As instalações adequavam-se à pluralidade cultural que encontravam. Na Índia, por exemplo, segundo o Arquiteto Walter Rossa, encontrava-se "um pouco de tudo":

São fortalezas isoladas; fortalezas dominando cidades préexistentes; cidades ocupadas, reestruturadas e fortificadas; cidades fortificadas feitas de raiz; correspondendo cada um destes casos, de um modo geral, a estádios progressivos de afirmação de poder ou de interesse econômico. [...] nas crónicas da Índia "fazer fortaleza" confundia-se com o acto de urbanizar. (ROSSA, 1995, p. 278).

As primeiras viagens visaram, segundo o autor, o estabelecimento de feitorias "[...] em locais cedidos pelos rajás sempre junto ao mar, em cabos, penínsulas, istmos, ilhas ou enclaves delimitados por rios [...]." (ROSSA, 1995, p. 279). Posteriormente as instalações foram sedimentadas. As cidades de Mazagão, Damão, Baçaim, Cochim, Goa, Diu e outras do expansionismo português também são estudadas em outra publicação do autor (1997). Rossa caracteriza o Brasil como "[...] um extenso território totalmente desurbanizado [...]", realidade "[...] comum às ilhas atlânticas, 'apenas' sendo diferente a imensidão e o facto de existirem indígenas com os quais inicialmente se pretendeu comerciar [...]." (ROSSA, 1995, p. 284).

Embora as sociedades indígenas pré-coloniais do Brasil sejam relativizadas pela historiografia, o encontro cultural decorrente do expansionismo mercantilista

\footnotetext{
18 "Com as reservas que qualquer generalização implica, é normalmente aceite a seguinte divisão: Magrebe [Norte da África]; ilhas atlânticas; costa ocidental africana; Oriente, expressão que neste caso engloba a costa oriental africana, o Mar de Omã, a Índia (costas de Malabar e Coromandel), o Ceilão e o Extremo Oriente; o Brasil." (ROSSA, 1995, p. 276).
} 
ocorreu aqui como nos demais domínios de matrizes européias. As resultantes dependeram de especificidades continentais, regionais e locais, onde a ação colonizadora, fortemente centralizada, deliberou os seus propósitos com isonomia. $\mathrm{O}$ atrelamento dos modelos tradicionais de análise urbana às interdependências econômicas e institucionais da Idade Moderna, todavia, pela generalização, pode macular a percepção e a identificação dos processos sociais específicos à gênese dos núcleos urbanos, dos quais são representações.

Ao estudarmos algumas Vilas litorâneas do atual Estado de São Paulo, procuramos filtrar a intensidade do domínio europeu, sedimentado na historiografia, para iluminarmos a substancial presença das sociedades indígenas nessa frente atlântica, antes e após os contatos com os brancos. A observação dos sítios, cenários ambientais, desenhos e imagens na linha do tempo, revelaram ao longo da pesquisa as evidências de suas singelezas. Atribuir unicamente a pequenos grupos (ou indivíduos!) estrangeiros, acolhidos por milhares de índios, os méritos e o sucesso desses estabelecimentos pareceu-nos uma excrescência. A percepção do "elo afetivo que as pessoas têm com seus lugares" relativo aos povos indígenas que ocupavam invariavelmente esses lugares de vivência há séculos, com os quais os ádvenas só sobreviveram porque interagiram culturalmente, levou-nos a perceber que a paisagem social deveria ter outras feições. E que, portanto, aqueles espaços não poderiam traduzir apenas o repertório cultural europeu.

Esse horizonte encaminhou nossa pesquisa para a investigação sobre os espaços indígenas e a ciência arqueológica contribuiu especialmente com a caracterização dos sítios de ocupação. Os mesmos lugares vivenciais das culturas pregressas, com vários componentes ambientais atrativos, foram eleitos para as instalações embrionárias do colonialismo. É a principal evidência de que as nossas 
Vilas são representações sociais do encontro cultural dos europeus com as sociedades pré-coloniais brasileiras. Houve um inegável seqüenciamento espacial nas antigas escolhas. A nova produção espacial, entre núcleos e rede urbana, apropria os mesmos nichos ecológicos, o mesmo habitat dos antigos ocupantes. $\mathrm{O}$ suporte da paisagem ambiental supera a singeleza dos edifícios embrionários e garante o sucesso das iniciativas. As portas do Novo Mundo estavam abertas.

Nas imagens dos núcleos estudados, uma recorrência simboliza o enlace dessas vertentes sociais: a articulação do módulo espacial da Matriz com a contigüidade da "rua direita". A proeminência dos novos valores na polaridade terrena do antigo habitat é o fim de uma longa caminhada, de um longo percurso. Os primitivos habitantes aceitaram o novo Deus, que prometia ser bom. Decerto contemplavam os frontões, as torres, encantavam-se com a sonoridade dos sinos e dos cânticos que ajudavam a entoar. Mas talvez não tenham compreendido porque sinalizavam o fim de suas antigas vivências, de suas antigas crenças, de suas festividades, de suas alegrias. Assistiram no curso de duas gerações a sua eminente derrota. Contra quem, muitas vezes, nem queriam lutar. 


\section{LISTA DE REFERÊNCIAS BIBLIOGRÁFICAS}

AB'SABER, AZIZ. Litoral do Brasil. São Paulo: Metalivros, 2005.

AB'SABER, AZIZ. O solo de Piratininga. In: BUENO, E (org). Os nascimentos de São Paulo. Rio de Janeiro: Ediouro, 2004.

ALMEIDA, Antonio Paulino de. A ilha de Cananéia. In: Revista o Arquivo Municipal, v. CLIV, a. XIX, p. 3-12. São Paulo: DAH/SEC/PMSP, 1952

AZEVEDO, Aroldo de. Vilas e cidades do Brasil colonial. São Paulo: USP, FFCL, Boletim no 208, Geografia, no 11, 1956.

AZEVEDO, Aroldo de. Embriões de cidades brasileiras. Separata do Boletim Paulista de Geografia. São Paulo, n. 25, p. 31-69. mar.1957.

BARBOSA, Gino Caldatto (org). Santos e seus arrabaldes: álbum de Militão Augusto de Azevedo. São Paulo: Magma, 2004.

BRITO, Bernardo Gomes de. História trágico-marítima. Lisboa: EuropaAmérica, 1971.

BUENO, Beatriz Piccolotto Siqueira. Desenho e desígnio: o Brasil dos engenheiros militares (1500-1822). Tese de Doutoramento. São Paulo: FAU/USP, 2003.

BUENO, Silveira. Vocabulário tupi-guarani português. São Paulo: Ed. Nagy, 1983.

BURKE, Peter. O que é história cultural?. Rio de Janeiro: Zahar, 2005.

CAMPOS, Jurandyr Ferraz de. Santo Antônio de Caraguatatuba. Caraguatatuba: FUNDACC, 2000.

CARDIM, Fernão. Tratados da terra e gente do Brasil. São Paulo: Nacional, 1978.

CORBIN, Alain. O território do vazio. São Paulo: Cia das Letras, 1989. 
CORRÊA, Dora Shellard. Historiadores e cronistas e a paisagem da Colônia Brasil. In: Revista Brasileira de História, v. 26, n. 51, p.63-87, jun. 2006.

DIEGUES, Antonio Carlos. A pesca construindo sociedades. São Paulo: NUPAUB- USP, 2004.

FERNANDES, Florestan. Organização social dos Tupinambá. São Paulo: Difusão Européia do Livro, 1963.

FORTES, Roberto. Iguape... nossa história. Iguape: Prefeitura Municipal, 2000.

FUNARI, Pedro Paulo. Teoria e a arqueologia histórica: a América Latina e o mundo. In: Vestígios - Revista Latino-Americana de Arqueologia Histórica. Belo Horizonte, v. 1, n. 1, p. 49-56, dez. 2007.

FUNARI, Pedro Paulo e NOELLI, Francisco Silva. Pré-história do Brasil. São Paulo: Contexto, 2005.

GÂNDAVO, Pero de Magalhães. A primeira história do Brasil. Rio de Janeiro: Zahar, 2004.

HOLANDA, Sérgio Buarque de. Caminhos e fronteiras. Rio de Janeiro: Cia das Letras, 1994.

HOLANDA, Sérgio Buarque de. Raízes do Brasil. Rio de Janeiro: José Olympio, 1971.

LEITE, Serafim, S.I. Cartas dos primeiros jesuítas do Brasil. V. II. São Paulo: Comissão do IV Centenário da Cidade de São Paulo, 1954.

LUÍS, Washington. Na capitania de São Vicente. São Paulo: EDUSP, 1980.

LYNCH, Kevin. A imagem da cidade. Lisboa: Novas Edições, 1990.

MACHADO, Lucy Marion. A paisagem valorizada: a Serra do Mar como espaço e como lugar. In: Percepção Ambiental. São Carlos: Ed. UFSC, 1986. 
MADRE DE DEUS, Gaspar da, frei. Memórias para a história da Capitania de São Vicente. Belo Horizonte: Itatiaia; São Paulo: EDUSP, 1975.

MARTINS, Carlos (curador). "Descripção de todo o marítimo da terra e S. Cruz chamado Vvlgarmente o Brazil" feito por João Teixeira cosmographo de Sua Magestade, anno de 1640. Rio de Janeiro: Fundação Estudar; Takano Ed., 2003.

MARX, Murillo. Cidade no Brasil terra de quem?. São Paulo: Nobel : EDUSP, 1991.

MARX, Murillo. Nosso chão: do sagrado ao profano. São Paulo: EDUSP, 2003.

MONTEIRO, John Manuel. Negros da terra: índios e bandeirantes nas origens de São Paulo. São Paulo: Companhia das Letras, 1994.

MONZEGLIO, Élide. Paisagens e cores: imaginários naturais e criados. In: Paisagem Paisagens 1. Bauru: UNESP, 1996.

NEME, Mário. Notas de revisão da história de São Paulo. São Paulo: Anhambi, 1959.

NEME, S. e BELTRÃO, M. C. Tupinambá, franceses e portugueses no Rio de Janeiro durante o século XVI. In: Revista de Arqueologia, São Paulo, 7: 133-151, 1993.

NOVAES, Adauto (org.). A descoberta do homem e do mundo. São Paulo: Cia. das Letras, 1998.

ODUM, Eugene Pleasants. Fundamentos de ecologia. Lisboa: Fundação Calouste Gulbenkian, 2004.

OLIVEIRA, Washington de. Ubatuba documentário. São Paulo: Ed. do Escritor, 1977.

PETRONE, Pasquale. Aldeamentos paulistas. São Paulo: EDUSP, 1995.

PETRONE, Pasquale. O povoamento antigo e a circulação. In: $A$ baixada santista, v. 2, c. III. São Paulo: EDUSP, 1965. 
PREZIA, Benedito. Os indígenas do planalto paulista. In: BUENO, E (org). Os nascimentos de São Paulo. Rio de Janeiro: Ediouro, 2004.

PROUS, André. Arqueologia brasileira. Brasília: Ed. Universidade de Brasília, 1992.

PROUS, André. O Brasil antes dos brasileiros. Rio de Janeiro: Zahar, 2006.

RAMOS, Fabio Pestana. No tempo das especiarias. São Paulo: Contexto, 2004.

REIS FILHO, Nestor Goulart. Evolução Urbana do Brasil. São Paulo: EDUSP, 1968.

REIS FILHO, Nestor Goulart. Imagens de vilas e cidades do Brasil colonial. São Paulo: EDUSP, 2001.

REIS FILHO, Nestor Goulart. Vilas paulistas do século XVII. São Paulo: LAP FAUUSP, sd

REIS, Paulo Pereira dos. O indígena no vale do Paraíba. São Paulo: Governo do Estado, 1979.

RIBEIRO, Darcy e MOREIRA, Carlos de Araújo. A fundação do Brasil. Petrópolis: Vozes, 1993.

RIBEIRO, Darcy. O povo brasileiro. São Paulo: Cia. das Letras, 1995.

ROSSA, Walter. A cidade portuguesa. In: PEREIRA, P (direção). História da arte portuguesa, v. 3, p. 233-323. Barcelona: Círculo de Leitores, 1995.

ROSSA, Walter. Cidades Indo-portuguesas. Lisboa: CNCDP, 1997.

SANDERSON, Ray. Meteorology at sea. London: Stanford Maritime, 1982.

SCATAMACCHIA, Maria Cristina Mineiro. I Seminário "Cananéia tem história". Prefeitura Municipal de Cananéia, 2005. 
SCATAMACCHIA, Maria Cristina Mineiro. A tradição policrômica no leste da América do Sul evidenciada pela ocupação Guarani e Tupinambá: fontes arqueológicas e etno-históticas. Tese de doutoramento. São Paulo: Departamento de Antropologia da FFLCH/USP, 1990.

SCATAMACCHIA, Maria C. e UCHÔA, Dorath P. O contato euro-indígena visto através de sítios arqueológicos do Est. S. Paulo. In: Revista de Arqueologia. São Paulo, 7: 153-173, 1993.

SCHADEN, Egon. Os primitivos habitantes do território paulista. In: Revista de História, n. 18, ano V. São Paulo, 1954.

SEED, Patrícia. Cerimônias de posse na conquista européia do novo mundo. São Paulo: Editora UNESP, 1999.

SMITH, Robert Chester. Arquitetura jesuítica no Brasil. Cadernos de pesquisa do $L A P$, n. 25, São Paulo: FAUUSP, 1998.

SOUSA, Gabriel Soares de. Tratado descritivo do Brasil. São Paulo: Nacional, 1987.

STADEN, Hans. Duas viagens ao Brasil. Belo Horizonte: Itatiaia; São Paulo: EDUSP, 1974.

TOLEDO, Benedito Lima de. O real corpo de engenheiros na Capitania de São Paulo. São Paulo: João Fortes Engenharia S.A., 1981.

TUAN, Yi-Fu. Topofilia. São Paulo: Difel, 1980.

YOUNG, Ernesto G. Subsídios para a história de Iguape. In: Revista do IHGSP, vol II, p. 286-375, São Paulo: Tipografia do Diário Oficial, 1908. 


\section{OBRAS CONSULTADAS}

AZANHA, Gilberto e LADEIRA, Maria Inês. Os índios da Serra do Mar: a presença Mbyá-Guarani em São Paulo. São Paulo: Nova Stella, 1988.

BRANCO, Bernardo Castello. Arquitetura indígena brasileira: da descoberta aos dias atuais. In: Revista de Arqueologia. São Paulo, 7:69-85, 1993.

BRUNO, Ernani Silva. História e tradições da cidade de São Paulo. Volume I. São

Paulo: Hucitec, 1991.

BUENO, Eduardo. Capitães do Brasil. Rio de Janeiro: Objetiva, 1999.

DIAS, Ondemar. Arqueologia de contato no Rio de Janeiro. In: Revista de Arqueologia. São Paulo, 7:125-132, 1993.

FUNARI, Pedro Paulo Abreu, (Org). Identidades, discurso e poder: estudos da arqueologia contemporânea. / Organização de Pedro Paulo Abreu Funari; Charles E. Orser Jr; Solange Nunes de Oliveira Schiavetto. São Paulo: Annablume; Fapesp, 2005.

GROSSI, Suely R. Del. Paisagens naturais e ação antrópica nas áreas do cerrado. In: Paisagem Paisagens 1. Bauru: UNESP, 1996.

HOLANDA, Sérgio Buarque de. Visão do paraíso: os motivos edênicos no descobrimento e colonização do Brasil. São Paulo: Brasiliense; Publifolha, 2000.

KANDINSKY, Vassily. Ponto. Linha. Plano. Lisboa: Edições 70, 1996.

KNIVET, Anthony. As incríveis aventuras e estranhos infortúnios de Anthony Knivet / Organização: Sheila Moura Hue. Rio de Janeiro: Zahar, 2007.

LÉRY, Jean de. Viagem à terra do Brasil. São Paulo: EDUSP, 1980.

MARIZ, Vasco e PROVENÇAL, Lucien. Villegagnon e a França Antártica: uma reavaliação. Rio de Janeiro: Nova Fronteira, 2000. 
MARX, Murillo. Cidade brasileira. São Paulo: EDUSP, 1980.

MÉTRAUX, Alfred. A religião dos Tupinambás. São Paulo: Nacional, 1979.

MILLER, René Füllöp. Os jesuítas: seus segredos e seu poder. São Paulo: Livraria do Globo, 1946.

MONTEIRO, John Manuel. et al. Índios no Estado de São Paulo: resistência e transfiguração. São Paulo: Yankatu Editora, 1984.

MOREAU, Felipe Eduardo. Os índios nas cartas de Nóbrega e Anchieta. São Paulo: Annablume, 2003.

MOREIRA, Rafael. A arte da ruação e a cidade luso-brasileira. Cadernos de pesquisa do LAP, n. 37. São Paulo: FAUUSP, 2003.

PARDI, Maria Lúcia Franco. A importância da arquitetura pré-histórica e indígena como referência dentro de um processo integrado de resgate cultural. In: Revista de Arqueologia. São Paulo, 7:87-97, 1993.

PETRONE, Pasquale. A porta e o porto do planalto. São Paulo: Instituto De Geografia - USP, 1969.

QUINTILIANO, Aylton. A guerra dos Tamoios. Rio de Janeiro: Relume, 2003.

REIS FILHO, Nestor Goulart. Quadro da arquitetura no Brasil. São Paulo: Perspectiva, 1978.

SAAB, Paulo. 1500: a grande viagem. São Paulo: Global, 1991.

SCHIAVETTO, Solange Nunes de Oliveira. A arqueologia Guarani: construção e desconstrução da identidade indígena. São Paulo: Annablume; Fapesp, 2003.

TEIXEIRA, Manuel C. O urbanismo português no Brasil nos séculos XVI e XVII. In: TEIXEIRA, M. C. e VALLA, M. O urbanismo português - Capítulo 6. Lisboa: Livros Horizonte, 1999. 


\section{APÊNDICE}

GIANESELLA, Rubens Ramos (argum.). Paisagens no tempo: vilas litorâneas paulistas. Audiovisual, 6:07 m. São Paulo: LEG, 2008. 1 DVD.

CRÉDITOS DO AUDIOVISUAL

Argumentação, fotografias e pesquisa: Rubens Ramos Gianesella

Edição:

Lívia Escobar Gabbai

Trilha sonora:

Missa 2IHU - kewere: rezar

Canto e composição:

Marlui Miranda

Texto em Tupi-guarani:

Padre José de Anchieta

Orquestra Jazz Sinfônica do Estado de São Paulo

Pau-brasil, 1977

São Paulo

2008 